DOELEIA-0609

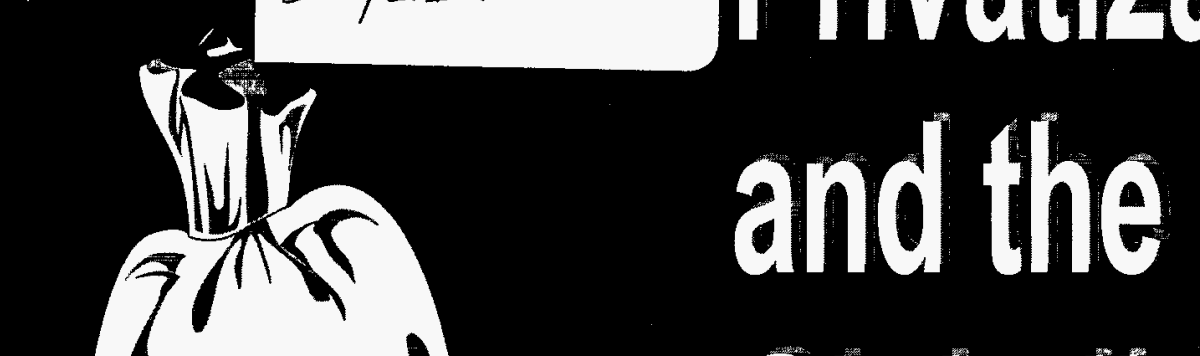

Privatzation

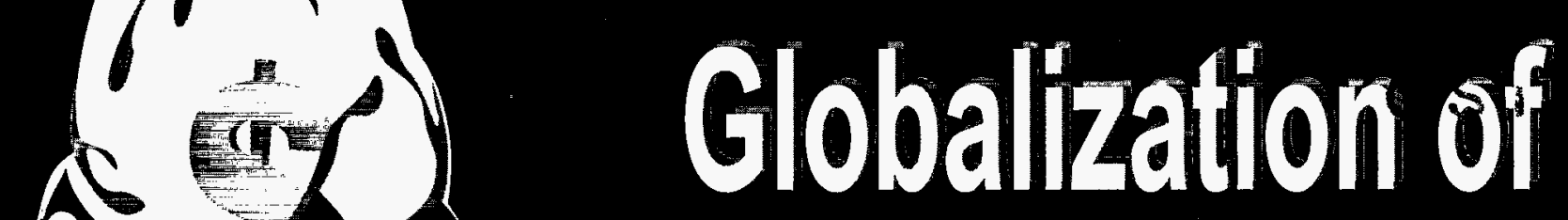

Energy Markets

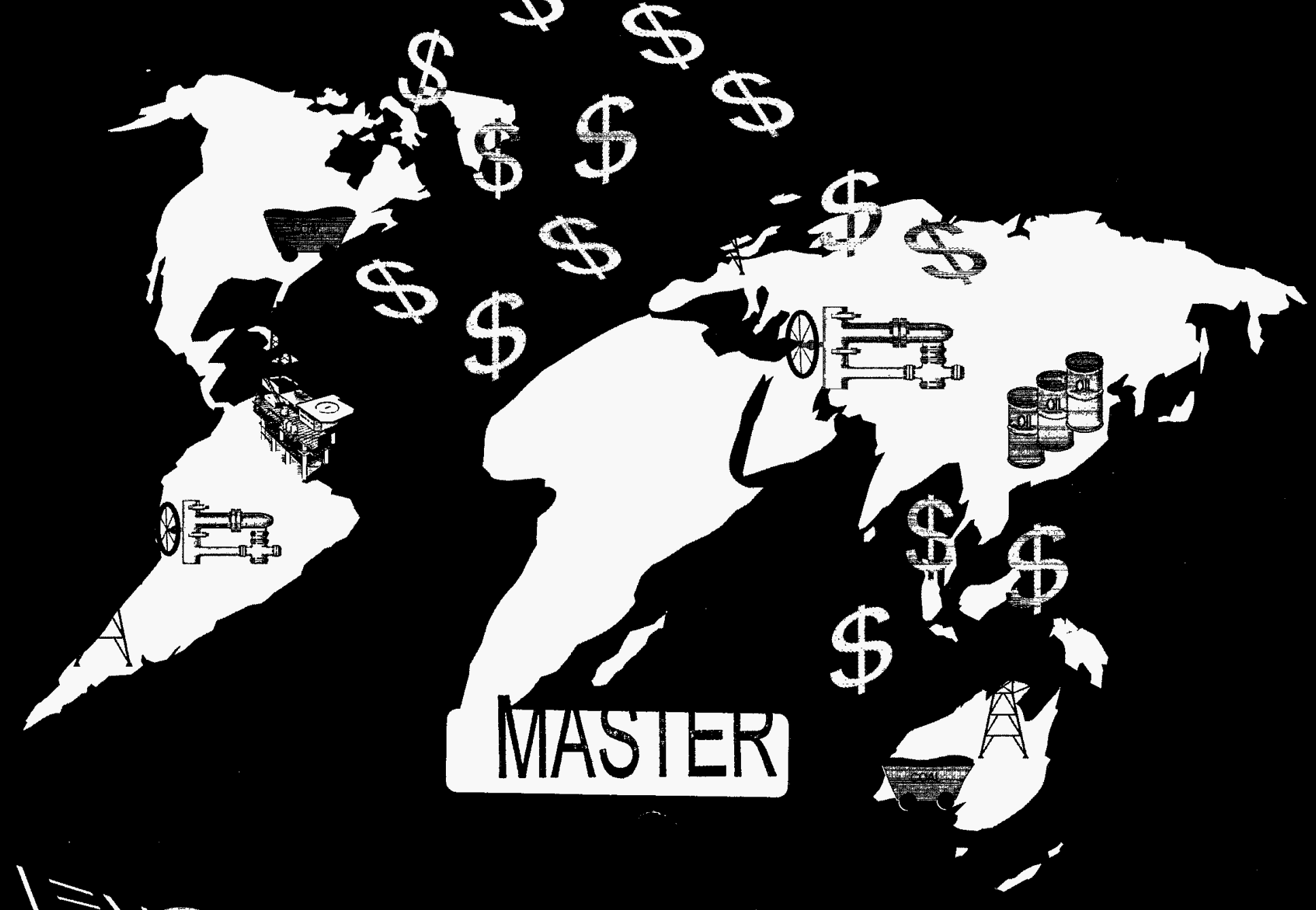

(

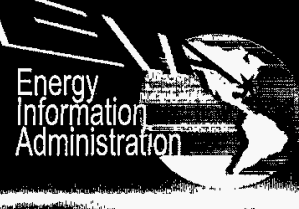




\section{HOW TO OBTAIN EIA PRODUCTS AND SERVICES}

For further information on any of the following services, or for answers to energy information questions, please contact EIA's National Energy Information Center:

$\begin{array}{ll}\text { National Energy Information Center (NEIC) } & \text { (202) 586-8800 } \\ \text { Energy Information Administration } & (202) 586-0727 \text { (fax) } \\ \text { Forrestal Building, Room 1F-048 } & \text { TTY: (202) 586-1181 } \\ \text { Washington, DC 20585 } & \text { E-mail: infoctr@eia.doe.gov }\end{array}$

Electronic Products and Services

EIA's Internet Site Services offer nearly all EIA publications. Users can view and download selected pages or entire reports, search for information, download EIA data and analysis applications, and find out about new EIA information products and services.

\section{World Wide Web: http://www.eia.doe.gov \\ Gopher: gopher://gopher.eia.doe.gov \\ FTP: ftp://ftp.eia.doe.gov}

EIA also offers a listserve service for EIA press releases and other short documents. Sign up on the EIA World Wide Web site.

EIA's CD-ROM, Energy InfoDisc, contains most EIA publications, several databases, and an energy forecasting model. The Energy InfoDisc, produced quarterly, is available for a fee from STAT-USA, Department of Commerce, 1-800-STAT-USA.

The Comprehensive Oil and Gas Information Source (COGIS), a bulletin board service, contains data files from most of EIA's oil- and gas-related reports. It is available for a fee from STAT-USA, on 1-800-STAT-USA.

EIA's Electronic Publishing System (EPUB) bulletin board contains data files, directories, and forecasts from most EIA reports. It can be accessed free of charge by dialing (202) 586-2557.

Many of EIA's data files and modeling programs are available for sale on diskette, tape, or cartridge, through either the National Technical Information Service or the Office of Scientific and Technical Information, Department of Energy. Contact NEIC for information on specific products, sources, and media, and ordering instructions.

\section{Printed Publications}

EIA directories are available free of charge from NEIC. Recent periodicals and one-time reports are available from the Government Printing Office. Older reports are available from the National Technical Information Service:
Superintendent of Documents
U.S. Government Printing Office
P.O. Box 371954
Pittsburgh, PA 15250-7954
National Technical Information Service
U.S. Department of Commerce
Springfield, VA 22161
(202) 512-1800; (202)-512-2250 (fax) (703) 487-4650; (703) 321-8547 (fax) 
DOE/EIA-0609

Distribution Category UC-950

\title{
Privatization and the Globalization of Energy Markets
}

\section{October 1996}

\author{
Energy Information Administration \\ Office of Energy Markets and End Use \\ U.S. Department of Energy \\ Washington, DC 20585
}

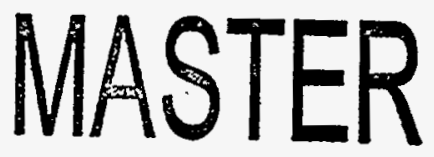

This report was prepared by the Energy Information Administration, the independent statistical and analytical agency within the Department of Energy. The information contained herein should not be construed as advocating or reflecting any policy position of the Department of Energy or any other organization. 


\section{Contacts}

This report was prepared in the Office of Energy Markets and End Use of the Energy Information Administration, U.S. Department of Energy, under the general direction of W. Calvin Kilgore. General questions concerning the content of the report may be referred to Mark E. Rodekohr, Director of the Energy Markets and Contingency Information Division (202-586-1130), and Mary E. Northup,
Chief of the Financial Analysis Branch (202-586-1445). Specific technical information concerning this report may be obtained from Kevin Lillis at (202-586-1395) or Jon A. Rasmussen at (202-586-1449). The following authors contributed to this report: Neal Davis (Chapter 3 and 5), Karen Doucet (Chapter 4), and Kevin Lillis (Chapters 1, 2, 5 , and 6).

\section{Diskette Information}

An appendix to this report is available in a Lotus wk3 format on a 3.5-inch high-density diskette. The appendix contains an extensive and detailed matrix of recent energy privatizations by country, by company, and by the function of the energy operation involved (e.g., coal operations or electricity generation operations). Please contact Kevin Lillis of the Energy Information Administration. Telephone (202) 586-1395, Fax (202) 586-9753, or by electronic mail through the INTERNET, klillis@eia.doe.gov. 


\section{DISCLAIMER}

Portions of this document may be illegible in electronic image products. Images are produced from the best available original document. 


\section{Contents}

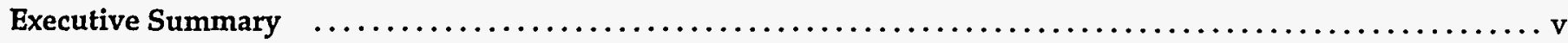

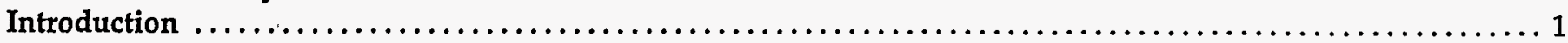

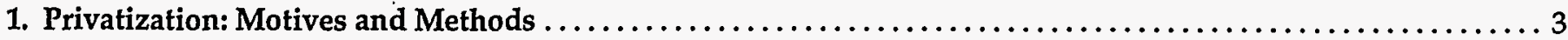

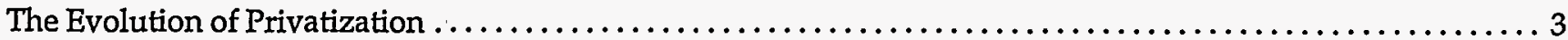

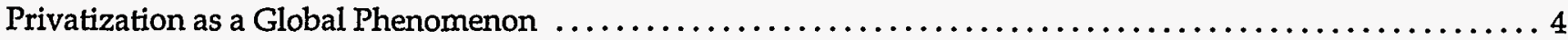

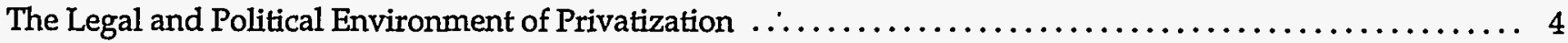

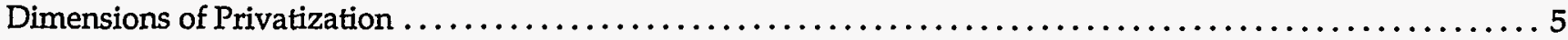

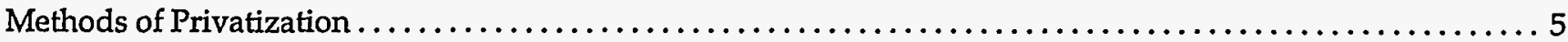

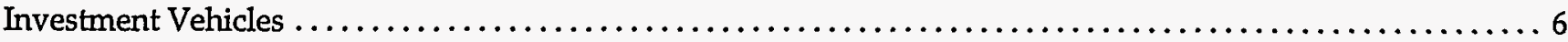

2. Profiles of Petroleum Privatizations in OECD Countries $\ldots \ldots \ldots \ldots \ldots \ldots \ldots \ldots \ldots \ldots \ldots \ldots \ldots \ldots$

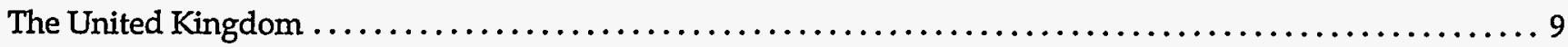

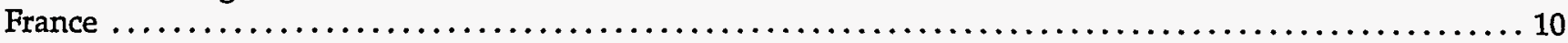

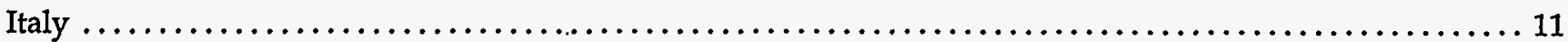

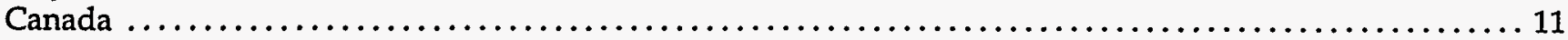

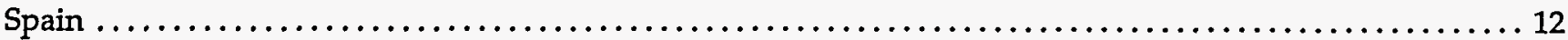

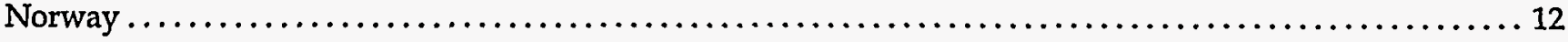

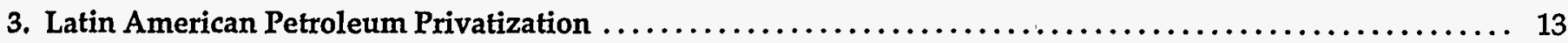

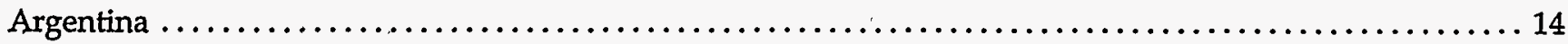

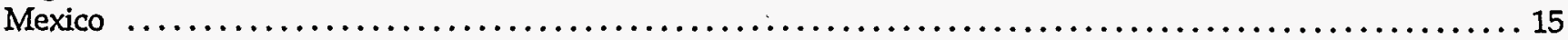

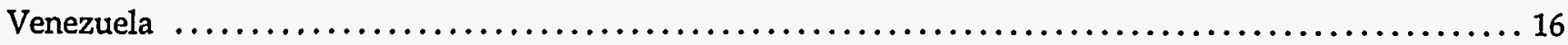

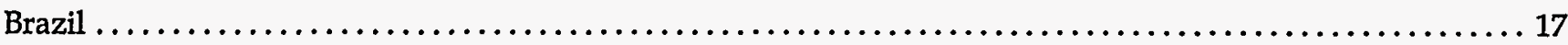

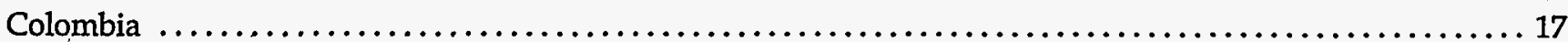

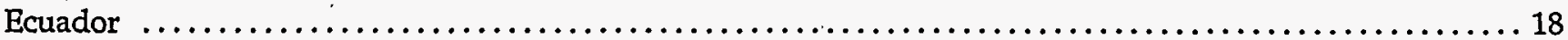

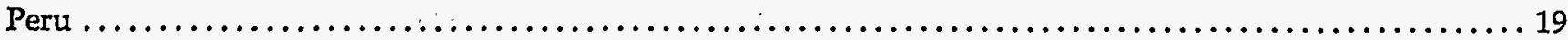

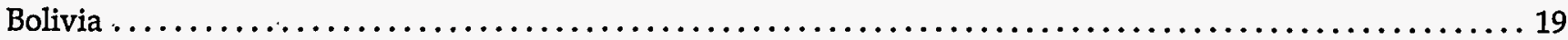

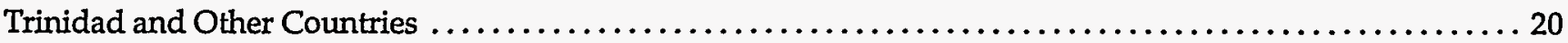

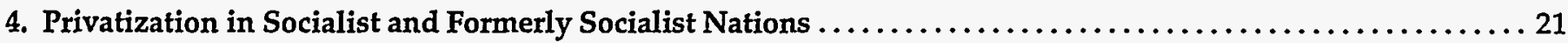

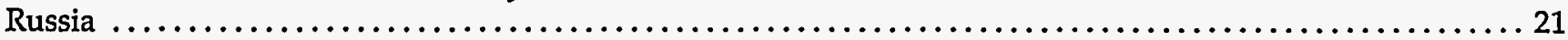

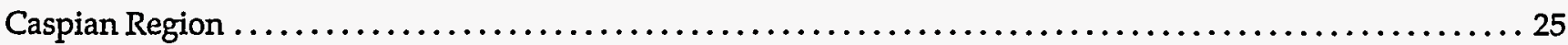

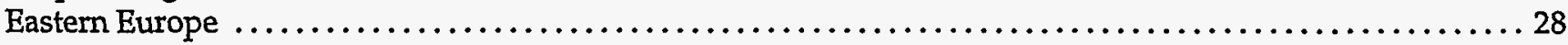

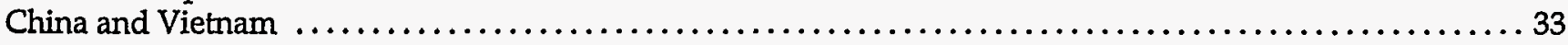

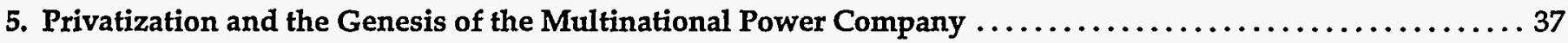

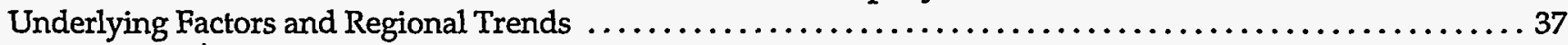

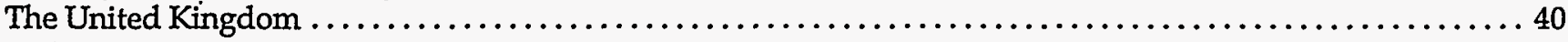

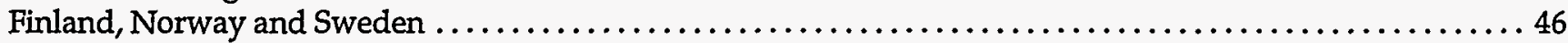

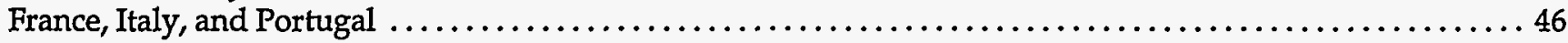

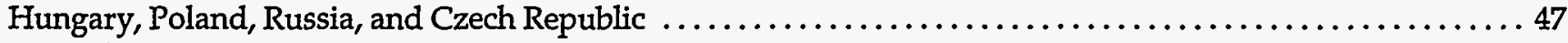

Australia ................................................................ 47

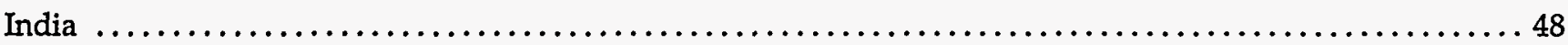

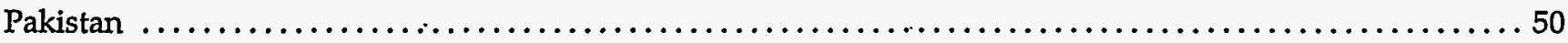

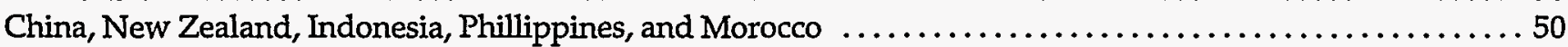




\section{Contents}

5. Electric Power Globalization and the Genesis of the Multinational Power Company Cont'd

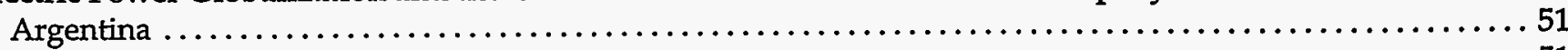

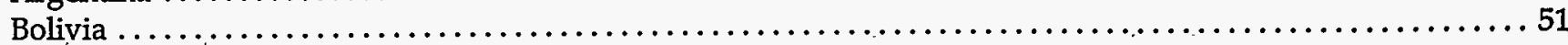

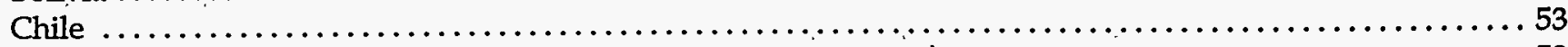

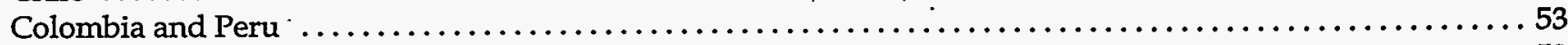

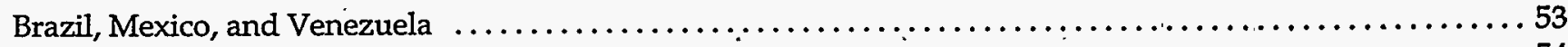

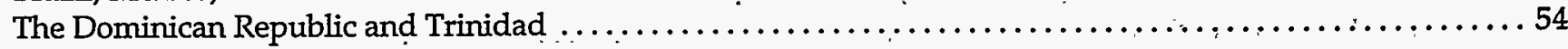

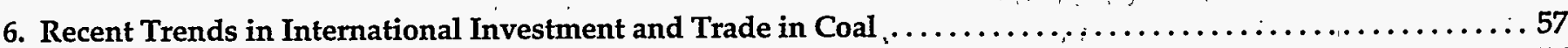

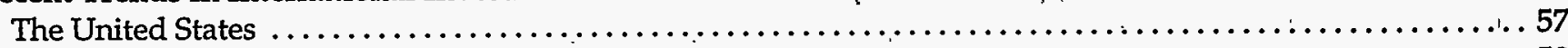

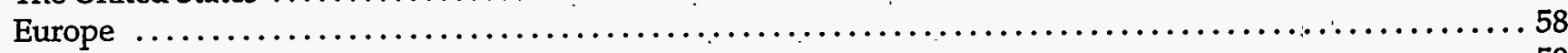

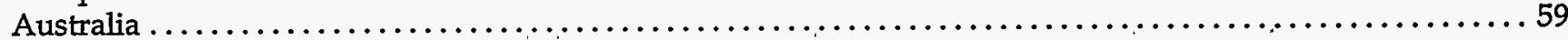

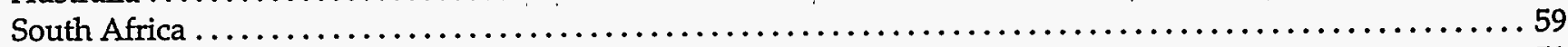

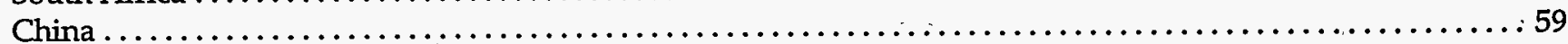

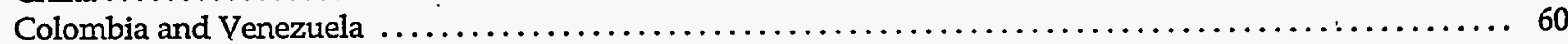

Appendix

Worldwide Privatization-Motivated Energy Investment $\ldots \ldots \ldots \ldots \ldots \ldots \ldots \ldots \ldots \ldots \ldots \ldots \ldots \ldots \ldots \ldots \ldots$

\section{Tables}

1. Worldwide Company Rankings for the Largest Latin American Petroleum Companies $\ldots \ldots \ldots \ldots \ldots \ldots 14$

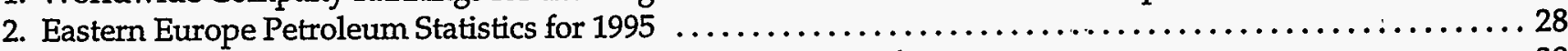

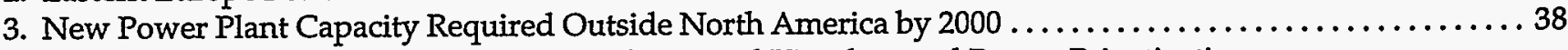

4. The Structure of the Electricity Market in the United Kingdom and Recent Privatization -

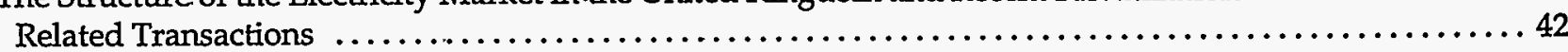

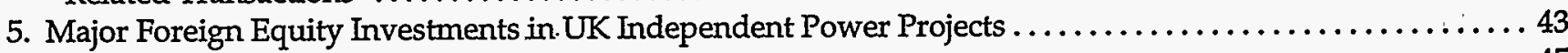

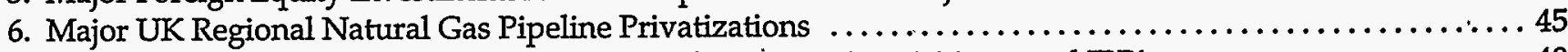

7. Australian Electric Utility Privatization-Related Mergers, Acquisitions, and IPP's ............... 49

8. Latin American Electricity Investment for Argentina, Bolivia, Chile, Colombia, and Peru by

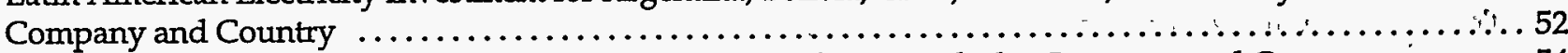

9. Electricity Privatization Investment in Brazil, Mexico, and Venezuela, by Company and Country ........55

10. Electricity Privatization Investment in Costa Rica, Dominican' Republic,Ecuador, El Salvador, Guatemala,

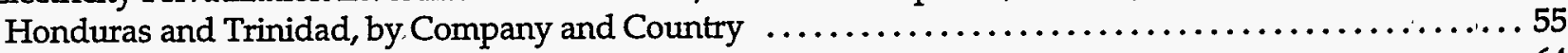

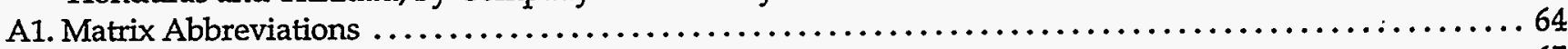

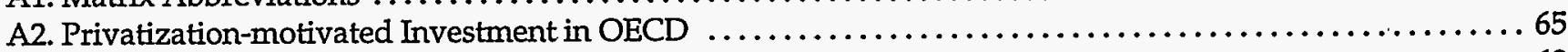

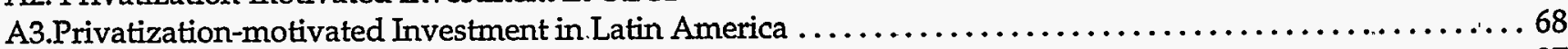

A4. Privatization-motivated Investment in Socialist and Formerly SocialistNations $\ldots \ldots \ldots \ldots \ldots \ldots \ldots \ldots . \ldots \ldots$

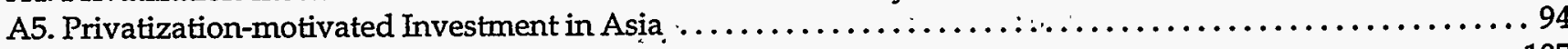

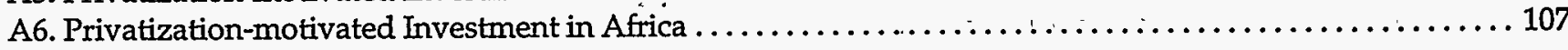




\section{Executive Summary}

The privatization of state-owned industry is a development of historic dimensions. For many nations, their formerly-state owned energy companies have been among the largest of companies to be privatized. Energy companies that have been privatized include some of world's largest petroleum companies based in the industrialized nations. Global giants, such as British Petroleum, British Gas, Elf Aquitaine (France), ENI (Italy), Petro Canada, Repsol (Spain), and TOTAL (France), have all recently undergone transitions from state-owned to some significant degree of private ownership. Other large petroleum companies lie in the countries of the Former Soviet Union and in Latin America, and have also been moving towards private ownership. These privatization efforts have led to billions of dollars in new investments and have presented opportunities to add oil and gas reserves of a magnitude unseen since the discovery of the North Sea and Prudhoe Bay fields.

Since the means by which different countries have privatized state-owned industries have varied considerably, we treat privatization in this report as any movement toward a market-driven economy--or any movement that diminishes public ownership and control and increases private ownership and control.

Privatization presents several concerns to shareholders, energy analysts, energy companies, policy makers, and to the general public at large. The opening of previouslyclosed overseas energy investments raises a number of issues. For example, for U.S. companies investing in newly -privatized energy activities abroad, in many cases, political risk has been a dominant element in privatization-related investment decisions. Often times, individual companies have committed hundreds of millions of dollars to these investments with serious uncertainty over even the short-term prospects of such projects. This development is one also watched carefully by shareholders and investment analysts.

For U.S. policy makers, the impact that privatization might have on maintaining a secure and affordable energy supply to U.S. consumers is also of importance. As more and more U.S. companies enter into foreign energy investments (often for the first time), the effects such investments will 'have on these companies' financial health and their domestic operations become another area of concern for policy makers.

Privatization has been widespread in electrical power generation, transmission, and distribution as well as in natural gas transmission and distribution. In Latin America and the United Kingdom, privatization of electric utilities and natural gas utilities has been mainly responsible for the emergence of new classes of investors, new hybrid energy companies, new investment financing vehicles, and massive cross-border investments.

This report discusses recent efforts at privatization in petroleum, electricity, and coal, as well as the impetus that privatization has provided in fostering the evolution of the multinational and multidimensional energy company. Of particular note:

- Privatization in such countries as the Former Soviet Union, and other formerly-socialist nations, has clearly widened the scope of the major petroleum companies to include previously off-limit exploration and development areas.

- Privatization has also fomented the greater integration of traditional petroleum companies into electric power, and the convergence of the electric power and natural gas industries.

There are both geographic and energy specific dimensions to privatization, both of which have served to form the outline of this report. The following sections highlight privatization efforts among global regions and forms of energy.

\section{Privatization of Non-U.S. OECD Petroleum Companies}

Relative to other energy companies surveyed in this report, privatization of the major oil companies located in countries belonging to the Organization for Economic Cooperation and Development (OECD) has caused only modest changes in industry behavior. Traditionally, OECD governments have exerted a much more limited degree of control over their nationalized petroleum companies than government in most other regions. Although many of the OECD's petroleum giants have 
until recently been publicly held, in many ways even these companies have operated almost as autonomously as some of the world's privately-held petroleum companies. Thus far, the most pronounced impact of privatization may be the increased level of ownership of several formerly-state run petroleum companies by foreign investors--particularly those from the United States. For many of these recently-privatized petroleum companies, reduced government oversight may have also freed management to pursue such politically sensitive decisions as redirecting investment spending overseas, and undertaking downsizing initiatives, particularly where reductions in labor force have taken place.

\section{Privatization of Latin American Petroleum}

Latin America is an area of rapidly growing exploration and development activity for U.S. energy companies. Privatization of petroleum operations in Latin America has occurred against a backdrop of sweeping free market economic reform. Central to Latin American economic reforms has been the privatization of a range of stateowned industries--from phone companies, to natural gas and electric utilities, to petroleum companies. The various countries of Latin America, however, have pursued different routes to privatization. At one extreme lies Argentina, which completely privatized its formerly-state owned petroleum company, YPF. At the other end of the spectrum lies Mexico, which has largely maintained its state-owned petroleum monopoly, Pemex, although allowing more latitude to foreign investors in Mexican petrochemicals. In general, privatization has allowed Latin American companies more freedom to pursue joint ventures with foreign companies. It has also led to an upswing in overall Latin American petroleum investment and may have encouraged the acquisition of some Latin American petroleum companies by foreign firms as well as the acquisition of foreign companies by some Latin American firms.

\section{Privatization Efforts in Eastern Europe and Socialist Asia}

In most Communist and former-Communist countries, the regimes recognize a need to rebuild their economies and are currently in a period of transition as they begin to adopt various market reforms. Each regime has embarked upon its own unique petroleum privatization scheme, allowing for different industry and ownership structures to emerge.
Privatization in Russia has involved both the creation of a domestic (and largely privately-held) industry out of the former state-owned petroleum monopolies and the opening up of Russian petroleum to foreign investors.

Foreign investment in Russia had long been put on hold, largely due to delays in the passage of a property rights law. Even after the legislation, the Oil and Gas Law, was enacted, apprehensions over the survivability of Russian democracy (and corresponding economic reform) continued to discourage foreign investment. In the Caspian Sea area, which includes Azerbaijan and Kazakhstan, in addition to Russia, delays in reaching an agreement on the route of an export pipeline (due to political differences among the nations involved) has held up billions of dollars in upstream investment in this region.

In other eastern European countries, privatization of petroleum has largely been a downstream affair. With the exception of Romania, eastern Europe has little in the way of petroleum production. Several eastern European nations have allowed foreign petroleum companies to invest in petroleum refining and marketing operations. The Communist governments of China and Vietnam are also attempting economic reform, albeit while retaining a monopoly hold on political power. Recent reforms in China and Vietnam include opening up areas for petroleum exploration that were previously inaccessible to foreign participation. Most of the resulting foreign investment in these countries is in the way of joint ventures and production-sharing agreements, and investment in petroleum exploration and development activity has proceeded at a uneven pace. Political uncertainties and legal difficulties remain the largest impediments to investment in these countries.

\section{Global Power Privatization}

Many developing countries are facing imminent power shortages as a result of rapid future growth in the demand for electric power. The future power generation needs of populous countries, such as Brazil, China, India, and Indonesia, are immense and present investment demands beyond the financial means of domestic capital markets. In the developing nations, privatization has largely involved the construction of new generating capacity and transmission lines. Foreign companies participating in these privatization efforts come from a variety of countries and represent a variety of industries.

In Latin America, privatization of electricity generation facilities has been widespread. Argentina has been a leader in the privatization of electric power, as it was in 
petroleum. Latin American electricity privatization has been primarily driven by a rapid increase in electricity demand, coupled with a shortage of domestic capital to meet future electric power generation investment needs. Privatization has involved both the sale of power operations to investors (both foreign and domestic) and agreements to allow incremental private investment (both foreign and domestic) in new electric facilities. Prominent among foreign investors are a number of U.S. electric utilities as well as some non-U.S. foreign utilities. Several petroleum companies have also entered the Latin American electricity market.

In Latin America, the privatization of electric utilities is related to the privatization of natural gas exploration and development operations. The emergence of a regional natural gas transportation system is critical to the development of new natural gas-fired electricity generation units. As a consequence, many international petroleum companies (particularly those with substantial natural gas production and transportation businesses) have vertically integrated themselves further downstream towards electricity generation in several Latin American countries.

Developed countries have also taken steps to privatize their electric power sectors. The most far-reaching of these privatizations have occurred in Australia and the United Kingdom. The evolving energy industries, as a result of privatization, have grown more integrated-both horizontally and vertically. In the United Kingdom, full service companies providing power generation and distribution, along with natural gas production and distribution, have emerged. In a few cases, recentlyprivatized water utilities and recently-privatized electric utilities have been combined. Another result of privatization has been the large-scale entry of foreign companies into these industries, largely through mergers and acquisitions. In both Australia and the United Kingdom (UK), U.S. investors--particularly U.S. electrical utilities-have been the most prominent foreign investors.

\section{Coal Privatization}

The privatization of the coal industries in Germany and the United Kingdom has had a decided impact on coal investment both in Europe and overseas. The removal of coal subsidies (an act of privatization) by these two European nations is largely responsible for the constriction of their domestic coal industries and the redirection of billions of investment dollars from coal operations in the United Kingdom and Germany to coal operations overseas. Well established producing countries, such as Australia and the United States, have been large beneficiaries of this redirected investment capital. Significant emerging coal-producing countries, such as Colombia and Venezuela, have also seen an increase in foreign investment in domestic coal operations, a fact which could result in these nations becoming substantial coal exporters. 


\section{Introduction}

Privatization and the Globalization of Energy Markets reviews recent global efforts to privatize energy resources and outlines the opportunities and challenges privatization has presented to U.S. and foreign multinational energy companies.

Scores of nations are privatizing their state-owned energy companies. For several reasons this development should be of particular importance to U.S. investors, energy analysts, energy policy makers, and energy producers and consumers. U.S. companies often have been key sources of financing the privatization of many foreign energy companies, a development of concern to both investors and policymakers. Policymakers in this country can also benefit from analysis of the various means by which different countries have adopted different privatization schemes. For instance, the far-reaching efforts at energy privatization in the United Kingdom have often been held up as a case study for other countries considering energy privatization. Privatization will also play a major role in determining the availability of future energy supplies and prices--a concern to both energy producers and consumers.

The study of recent energy privatization efforts can be approached from several viewpoints. There is a regional aspect to privatization. For example, in Latin America energy privatization efforts can be viewed as a sweeping regional adoption of free market economics. However, there is also an energy sector perspective to privatization. For instance, while some nations have welcomed freer foreign investment in energy sectors, such as petroleum refining or marketing, some have remained reluctant to offer the same level of unrestricted investments in the petroleum production sector. Further, there is the perspective of the energy enterprise, or the nature of the company being privatized, since the privatization of companies such as British Petroleum differ markedly from the privatization of, for instance, the oil companies of the Former Soviet Union.

In early 1996, the Energy Information Administration publication Performance Profiles of Major Energy Producers 1994 took an initial look at the privatization of stateowned energy industries in China, Latin America, and the Former Soviet Union (FSU), and the opportunities that these privatizations presented to the major U.S. petroleum companies. That report focused primarily on petroleum investments. This report, Privatization and Globalization of Energy Markets, expands the coverage of that effort in a number of ways. The group of energy companies studied in this report includes not only the major U.S. petroleum companies but also many major foreign companies. The latter group consists of both state-run energy enterprises, recently privatized energy enterprises, and foreign multinationals that have long been privately held. The privatization of non-petroleum energy industries, such as electricity generation and transmission, natural gas transmission, and coal mining, are also discussed in this report, as are the overseas investments made by electric companies, natural gas companies, and coal companies. The regional coverage of the current report has also been expanded to include, for example, privatization efforts in such areas as non-FSU Europe, the OECD, and a number of developing countries.

Energy privatization is a large development and is taking place in more countries than those covered in this report. The purpose of this report is to highlight some of the more important privatization efforts occurring in global energy. For instance, since the late 1970's the United States has undertaken a series of efforts to deregulate domestic energy markets. This effort, however, is described thoroughly in other Energy Information Administration publications, and hence is not addressed in this report. There are several other dimensions to global energy privatization that fall outside the purview of this report. For instance, many foreign countries have adjusted their tax regimes to enhance the competitiveness of their energy industries, which also is a form of privatization. Although this report often makes reference to energy related investments that are generally deemed to be relatively risky, it is beyond the purpose of this report to quantify risk. Further, whatever disadvantage U.S. companies face relative to many of their newly-privatized major competitors (due to such factors as embargoes and other trade restrictions) also falls outside the scope of this report.

This report is organized along the following lines. The first chapter addresses the economics of privatization-what motivates countries to privatize, and what countries and companies hope to gain from it. The second chapter discusses petroleum privatization efforts among non-U.S. OECD nations. The third chapter reviews petroleum privatization efforts in Latin America. The fourth chapter 
looks at privatization in socialist and former socialist regimes. The fifth chapter reviews privatization efforts in global electric power generation, transmission, and distribution industries. The sixth chapter discusses recent developments surrounding the privatization and globalization of world coal. Lastly, the appendix provides the reader with a reference source of summarized information. 


\section{Privatization: Motives and Methods}

\section{The Evolution of Privatization}

Energy privatization has been part and parcel of a recent world trend which has placed greater reliance on market forces and less dependence on government in the allocation of resources. Since the means by which different countries have privatized state-owned industries have varied considerably, we treat privatization in this report as any movement toward a market-driven economy-or any movement that diminishes public ownership and control and increases private ownership and control.

In part, privatization's roots stem from the recent decline of socialism as well as from the growing conviction that free enterprise advances the wealth of nations better than nationalized industries and planned economies. Both mixed-market and socialist (or formerly socialist) economies have engaged in various privatization efforts in recent years.

Privatization represents a reversal of the process of nationalization begun early in this century. In most Communist nations, a wave of nationalizations ensued shortly after Communist governments assumed power in the aftermaths of World War I (WWT) and World War II (WWII), In Western Europe, the nationalization process stretched over several decades but essentially took hold in the 1930's. At the time, European governments of divergent political viewpoints were largely in agreement over the benefits of a strong state role in their domestic economies. "Nationalization represented a cherished postwar European ideal to create large vigorous state-owned businesses that provided pools of public jobs and allowed European politicians to wield influence over their economies. A wide consensus of European politics after held that a strong, government-owned industrial sector was necessary for prosperity and middle-class stability." In the 1930's Spain, the Franco government nationalized the state petroleum resources, which later emerged as Repsol-Spain's state oil company. The Mussolini government in Italy did the same and formed what was to become ENI, Italy's state petroleum company. Energy resources were nationalized at about the same time elsewhere in Europe-although in other nations often by more freely-elected governments.

In other regions, nationalization often involved the expropriation of foreign-owned domestic petroleum properties. Russia was the first to nationalize its petroleum industry following the Bolshevik Revolution in 1918. In 1938, Mexico nationalized what was at the time an industry largely held by U.S., UK, and Dutch interests. Later waves of nationalizations (and expropriations) followed in the post-war era in Latin America and the Middle East.

However, in the West, by the late 1970 's, nationalized industries began to lose favor. Disenchantment with state ownership grew as government enterprises began to be perceived as bloated and inefficient. This view caught on with liberal and conservative parties throughout the world. Recently, the British labor party leader called for the abolishment of the labor party's constitution clause calling for the nationalization of industry-long one of the bedrocks of the British labor movement's constitution. ${ }^{2}$ Other liberal parties have also embraced privatization. As a result of this historic change in attitude toward stateownership, such companies as Repsol and ENI-along with a host of other formerly state-owned companies-are now being privatized.

In the East, the collapse of Communism precipitated later efforts to adopt market economies and privately-held industry. Even among still avowedly socialist regimes, such as China, a move to free market-based reforms and privatization has been evident for several years.

Among the developing countries, privatization has also been widespread. With the exception of Cuba, virtually all of Latin America has adopted some form of privatization. Chile-Latin America's pioneer at privatizationand, later, Argentina, Peru, and Colombia have

\footnotetext{
"'Economic Change Social Upheaval; Governments Cutting Welfare Benefits, Selling State-run Firms," The Washington Post (August 7, 1994), p. A1.

2"British Labor Party Scraps nationalization Clause," The Wall Street Joumal (May 1, 1995), p. A11.
} 
undertaken the most ambitious privatization efforts. Among developing Asian nations, electric power privatization has been most prominent in countries such as Pakistan, the Phillippines, Malaysia, and Indonesia. The two most populous nations of Asia, China and India, have also embarked on various forms of energy privatization.

\section{Privatization as a Global Phenomenon}

Privatization has also been driven by the increasing globalization of the world economy. Several decades of rapid growth in international trade and investment have made competitiveness in international trade an essential factor in a nation's ability to create jobs, raise real wages, and generate wealth.

For many nations, privatization has become the only effective method of raising investment capital on favorable terms. High levels of past public sector borrowing have saddled many nations with large levels of debt. As a consequence, these nations have had little recourse but to sell state assets to reduce debt, generate revenue, and raise investment capital. ${ }^{3}$

Countries as different as the United Kingdom and Chile have led the way in privatization. Countries as different as Peru and Poland have followed. Between 1988 and 1993, roughly 2,700 state-owned enterprises in over 95 countries were transferred to private individuals, raising over $\$ 270$ billion. ${ }^{4}$ In Western Europe, the United Kingdom was at the forefront of privatization. Britain has raised $\$ 95$ billion through the privatization of formerly state-owned enterprises. ${ }^{5}$

Various businesses have been privatized besides oil. Indeed, the largest privatization to date has been the sale of Japanese Telecom for $\$ 73$ billion. $^{6}$ In the United Kingdom, public housing has been privatized and, in the United States, many municipal services, such as waste disposal, have been privatized.

Although privatization efforts differ substantially from country to country, there is a strong common economic rationale underlying the various decisions to privatize state energy resources. In general, nations have privatized state-owned energy industries to achieve one or more of several objectives. These objectives include: 1) raising revenue for the state; 2 ) raising investment capital for the industry or company being privatized; 3 ) reducing government's role in the economy; 4) promoting wider share ownership; 5) increasing efficiency; 6) introducing greater competition; and 7) exposing firms to market discipline.?

Privatization is closely connected with the development of the international energy company-a company whose focus is becoming both more global and more multipurpose. Until recently, outside of the world's few major integrated oil companies, only a handful of energy companies were considered multinational. Currently, in addition to the scores of petroleum companies that can now be classified as multinational, the scope of many coal companies, petroleum pipeline companies, electric utilities, and power generation equipment and construction companies, has become increasingly global. Through consolidations, mergers, acquisitions, and strategic alliances, the world's energy companies have also become more integrated. Oil and gas companies have become electricity companies; domestic regional electric utilities have become multinational electricity companies; electricity distribution companies have become generation companies; and generation companies have become distribution and transmission companies.

\section{The Legal and Political Environment of Privatization}

In many regions, progress at privatizing state petroleum companies has been uneven. Some countries' privatization efforts have faltered, in part due to lingering nationalistic views towards energy resources, particularly oil. On more than one occasion, progress at privatization has suffered severe setbacks. For example, billions of dollars of planned investment activity in Russia has for a long time been put on hold awaiting passage of a property rights law. A growing possibility that a Communist led government might regain power has been another factor causing foreign investors to be apprehensive about their investment commitments in Russia.

\footnotetext{
${ }^{3}$ The World Bank Report of 1994, The World Bank (New York, Oxford University Press, 1995).

4"'Sale of the Century,"The Wall Street Joumal (October 2, 1995), p. R4.

s"Sale of the Century," The Wall Street Journal (October 2, 1995), p. R4.

"'Sale of the Century," The Wall Street Journal (October 2, 1995), p. R4.

${ }^{7}$ The objectives of privatization appeared in: Privatization: Learning the Lessons from the U.K. Experiences (London, U.K., Price Waterhouse, 1989). However, objective number two, "to raise investment capital for the privatized industry or company," was added by the authors of this report.
} 
Further, the specter of re-nationalization has not been limited to the new democracies of Eastern Europe. In August of 1995, for instance, the newly-elected state government of Maharashtra, India, temporarily pulled out of a deal negotiated by the central government with Enron to build and operate a \$3-billion electricity generating plant after Enron and its partners had already invested several hundred million dollars. ${ }^{8}$ The newly-elected government alledged that the previous government had secretly negotiated the contract with Enron under terms that favored Enron and disadvantaged consumers. ${ }^{9}$ Subsequently, in December of 1995, Maharashtra and Enron successfully reached a renegotiated agreement allowing the project to proceed.

Privatization almost always involves some changes in a nation's legal system. In several regions, legal reform has been an important key to the successful privatization of state-owned industries, especially with regard to the protection of property rights and the reliable enforcement of contracts. The equal treatment of foreign investors and domestic investors by the judicial system has also been important.

\section{Dimensions of Privatization}

Privatization efforts are occurring in several different regions, nations, and industries. Although some clear patterns have emerged, there are many different forms and variations of privatization. One example of an aggressive attempt at privatization is when a government completely divests itself of all state-owned enterprises to the public and fully removes itself from the control and management of these enterprises. There are also several less substantial forms of privatizing. At the other extreme, a government may implement a deregulatory policy which allows an industry only a marginal amount of greater autonomy or may just contract out a service that was formerly performed by government workers, such as trash collection. Privatization can also be achieved without doing much of anything. If, for example, the private sector is growing while the public sector is shrinking, privatization is being achieved through attrition.

Recent efforts have also varied considerably in terms of the speed at which companies have been privatized. In some cases, recent privatizations have been sweeping-involving the transformation of state-owned petroleum monopolies into completely privatized companies, almost overnight. However, more typical is the case of gradual privatization. Even in the most farreaching privatization efforts-such as in the United Kingdom-several years have gone by between the time government committed itself to privatizing industries and the full transfer of ownership to the public.

The role of the foreign investor has been an important factor in the privatization process. In some political jurisdictions, few, if any, restrictions have been placed on foreign investors. In the Australian state of Victoria, for instance, when five of the state's electric distribution companies were auctioned off, all were purchased, at least in part, by U.S. companies. Countries such as the United Kingdom and Argentina have also been at the forefront in allowing relatively nondiscriminatory treatment of foreign investors. In other cases, restrictions on foreign investment have been inhibiting. Several of the former Communist regimes, for example, along with China, have undertaken relatively moderate and often vacillating steps towards opening their energy sectors to foreign investment. In general, these countries have relied on joint ventures with state-controlled enterprises as an approved vehicle for foreign investment in their energy industries.

Governments have often undertaken a vast restructuring of energy industries prior to the transfer of ownership to the public. In Russia, for example, privatization has involved the creation of eleven vertically integrated petroleum companies, along with a large natural gasproducing company and a large transmission company. In other countries, a restructuring has ensued largely after the transfer of ownership from state to private hands. In the United Kingdom, a merger and acquisition frenzy ensued following the recent privatization of electricity generation, transmission and distribution industries, as well as in the natural gas transmission and distribution industries.

It should be noted that the privatization of an industry does not mean that governments relinquish their authority to regulate these industries. In many cases, the politically sensitive issue of what allowances could be made to electric utilities being privatized in their freedom to adjust residential electricity rates has placed constraints on the privatization process.

\section{Methods of Privatization}

National governments have pursued various methods of privatization-the motivations for which are as various as

\footnotetext{
${ }^{8}$ The New York Times (August 4, 1995), p. D2.

9"Enron Pursues Arbitration in Dispute Over Project Canceled by Indian State," The Wall Street Journal (August 7, 1995), p. B6A.
} 
the methods themselves. The following are a number of the more common means of achieving greater private control over energy resources.

\section{Direct Sale of Entire Company to Public}

In some instances, countries have chosen to transfer ownership of industries or companies swiftly and completely. Argentina, the United Kingdom, Chile, and New Zealand have generally undertaken some of the most ambitious of privatization efforts by auctioning off companies directly to the public-thereby letting the market determine the value of these companies through the bidding process. In some cases, (for example, see the discussion on the privatization of British Energy) the auctioning off of a company has revealed an enormous divergence between newly-discovered market value and the previous book value of the company as recognized by the government.

\section{Partial Sale of Company to Public}

Most privatizations have been gradual. For example, in the case of British Petroleum, partial government ownership dates back to 1914. In 1977, the government reduced its ownership share from 66 percent to 51 percent, to 46 percent in 1979, to 31 percent in 1983, to under 2 percent in 1987, and to zero in 1995. Also, governments have often sold shares of a state-owned firm while still retaining a portion of the company (a "golden share"), thereby maintaining a limited degree of control over the company. This practice has been widespread, both in OECD and nonOECD countries. ${ }^{10}$

\section{Sale of a State-Owned Company to Another Company or Consortiums}

Often governments have chosen to sell state-owned utilities directly to companies - either foreign or domestic. For example, when Bolivia privatized the state electricity monopoly, Ende, it was broken into three electricity generation companies and directly sold off to foreign-primarily U.S.-utility companies.

\section{Deregulation}

Another form of privatization involves deregulation. Deregulation has been the most prevalent form of energy privatization in the United States, most recently in natural gas transportation and electric power generation and transportation. Electric power generation, transmission, and distribution has long been held up as a model for the "natural monopoly." However, as the notion of a what constitutes a natural monopoly has evolved, so has the justification for maintaining government-controlled utilities.

\section{Removal of Subsidies}

The removal of a subsidy can also be viewed as a form of privatization. The removal of subsidies for European coal operations, for example, precipitated the constriction of Europe's coal mining industry and encouraged a large shift in coal investment from European mines to mines in the United States, Australia, and Latin America.'

\section{Voucher Schemes}

Another aspect of privatization concerns how public ownership is achieved. In many formerly Communist countries, voucher schemes have been adopted whereby ownership of an industry is simply transferred to the general public with no cash exchanged. A lack of developed equity markets may have encouraged voucher schemes. After the initial distribution of vouchers, individuals have been allowed to buy or sell these vouchers, thereby encouraging the creation of stock exchanges. In some instances, the transfer of ownership has been implemented with labor and management being allotted favored shares.

\section{Investment Vehicles}

Privatization has opened enormous opportunities for foreign investors. In overseas energy projects, companies which in the past had generally avoided equity commitments have now begun to take financial stakes in projects. Some of the world's major construction companies and electrical generation equipment companies have taken equity stakes (in lieu of payment for services) in power generation projects brought on by privatization, albeit these stakes, have generally amounted to a small share of the total capital commitment. Some commonly used means of taking direct stakes in newly-privatized foreign energy projects follow.

\footnotetext{
${ }^{10}$ The Organization of Economic Cooperation and Development (OECD) includes Australia, Austria, Belgium, Canada, Denmark, Finland, France, Germany, Greece, Iceland, Ireland, Italy, Japan, Luxembourg, the Netherlands, New Zealand, Norway, Portugal, Spain, Sweden, Switzerland, Turkey, the United Kingdom, and the United States.
} 


\section{Independent Power Producers}

Independent power producers are playing an important and growing role in providing for the world's future power generation needs. Independent power producers are generally producers of electricity that are separate from franchised electric utilities. In several cases, U.S. utilities have formed independent power-producing subsidiaries as a vehicle of entry into non-utility electricity generation investments, both in the United States and overseas. Other industries, such as oil companies and natural gas transmission companies, have also set up independent power-producing subsidiaries. Among U.S. companies, independent power producers have been among the most active in seeking overseas energy project investments.

\section{Build, Operate, and Transfer Investments}

One innovative financing method growing in popularity involves the building of a power plant by a foreign investor, operating it for a prescribed period of time, and then transferring it to the host company. This has been a popular means of encouraging foreign investment in power projects in underdeveloped and developing nations.

\section{Joint Ventures}

In several former Communist countries, along with a handful of Latin American countries, most foreign investment commitments have been restricted to a joint venture with a domestic company. In some cases, such as in Russia, the government has also allowed foreign companies to purchase a limited stake in domestic petroleum companies. 



\section{Profiles of Petroleum Privatizations in OECD Countries}

One of the largest energy privatization developments in terms of investment capital involves petroleum companies located in the OECD countries. This group of companies includes: British Petroleum, Elf Aquitaine (France), TOTAL (France), ENI (Italy), Petro Canada, Repsol (Spain), and Statoil (Norway).

These companies have been among the most active of the world's petroleum companies in responding to investment opportunities occasioned by privatizations beyond their home base political borders. Most of these petroleum companies are vertically integrated and most have substantial foreign operations. Among these companies are some of the world's largest publicly-traded companies and, in several cases, the largest industrial companies in their respective home nations. They are also increasingly owned by international investors, in particular, those located in the United States. As with the U.S. major petroleum companies, these companies are increasingly operating in regions recently opened up due to privatization efforts, and they are becoming major operators in regions such as Latin America, China, the Former Soviet Union, and Southeast Asia.

The histories of these companies vary considerably. In recent years, some of these companies have been fully privatized, some partly. In general, privatization of these petroleum companies has occurred in the context of a wide scale privatization of several state-owned industries.

However, some states have been reluctant to fully relinquish control and have continued to retain a 10-percent controlling interest, a "golden share."11 One of these companies, Statoil of Norway, remains entirely-state owned.

These companies are in many ways the most direct competitors of the major U.S. petroleum companies, in part due to the close interconnection of the European and
North American petroleum industries. British Petroleum, for instance, is the largest producer of crude oil in the United States. British Petroleum is also the sixth largest U.S. refiner and is among the top ten branded marketers of gasoline in the United States. Other recently-privatized European companies, such as TOTAL and Elf Aquitaine of France, also have sizable U.S. petroleum investments.

Similarly, U.S. companies play a major role in European industry. Roughly 90 percent of European crude oil production comes from Norwegian and British territories in the North Sea, ${ }^{12}$ and U.S.-based companies account for roughly one-fourth of North Sea production. The European presence of U.S. companies in downstream petroleum is also very strong. Exxon and Mobil alone account for one-fourth of Western European refining capacity. Chevron, Dupont, and Texaco also have a major presence in European downstream. Moreover, in 1996, British Petroleum and Mobil agreed to combine their European refining and marketing operations; the combined operation will control roughly 12 percent of the European fuel market. ${ }^{13}$ Companies from the United States also play a major role in European crude oil and natural gas transmission and distribution as well as in retail gasoline marketing.

\section{The United Kingdom}

British Petroleum (BP) was founded as the Anglo-Persian Oil Company in 1909. In its early years, BP's primary producing properties were located in Iraq, Abu Dhabi, Kuwait and Qatar. Between 1914 and 1995, the British government maintained an interest in British Petroleum, and at times the government's holdings exceeded fifty percent. The privatization of BP began about 10 years ago when the British government sold about 32 percent of the company to the public. In 1995, the final 1.8 percent

\footnotetext{
"One motive for privatizing only a small portion of a state-owned enterprise has to do with the concept of "price discovery." Allowing even a small fraction of an enterprise's shares to be publicly traded enables the market to signal an appraisal of the value of the entire enterprise. This would be one means for the state to measure management performance.

${ }^{12}$ Energy Information Administration, International Energy Review 1993, DOE/EIA-02219(93)(Washington DC, May 1995), p. 22.

13،"Plan to Mix Oil with Oil in Europe," The New York Times (March 1, 1996), p. D3.
} 
government share in BP was sold to the public, making BP a fully-privatized company. British Petroleum is the twelfth largest producer of crude oil in the world. BP is also Britain's largest industrial company. BP's downstream operations are also sizable. BP is the world's fifth largest refiner, with $B P^{\prime}$ 's downstream operations largely based in Europe and the United States.

Recent energy privatizations in several global regions has resulted in a substantial number of new investment opportunities for BP. In recent years, BP has continued to expand its retail networks in Eastern Europe and it has added nearly 100 service stations in eastern Germany, the Czech Republic, and Hungary. In recent years; BP has targeted new frontier petroleum areas for investment. The company has reached a \$3.5-billion agreement with Sonatrach to develop gas fields in Algeria. ${ }^{14} \mathrm{BP}$ is 'also a major player in Colombia and Vietnam, and is pursuing exploration opportunities in Venezuela and Azerbaijan. ${ }^{15}$ Since 1990, BP and Statoil, the Norwegian state oil company, have been working in close commercial cooperation in a number of areas. A program of joint research is underway, and the two companies are also undertaking joint exploration and development work in Azerbaijan, Kazakhstan, Vietnam, Angola, and Nigeria. ${ }^{16}$

In contrast to its decided move into several frontier areas, and as a result of having undergone a substantial restructuring of operations in recent years, BP has generally reduced its level of investment in the company's historic markets. This restructuring has been most evident in downstream petroleum. Since 1991, BP has reduced its employment level in refining and marketing operations by 32 percent versus a 23 -percent reduction in upstream employment. ${ }^{17} \mathrm{BP}$ has sold three of its U.S. refineries in recent years and has sold marketing operations in California and Florida. In 1995, BP announced plans to shut down or sell three refineries in the U.S. and Europe, cutting capacity by nearly a third. ${ }^{18}$ In 1994, BP sold its Spanish retail network (excluding motorway sites) to Repsol and, in 1996, announced that it would close 250, or 17 percent of its retail gasoline outlets in Germany. ${ }^{19}$

One result of privatization has been the company's increased attraction to foreign investors, particularly those based in the United States-the largest capital market in the world. British Petroleum is currently 17 percent held by U.S. investors, up from 6 percent ownership as recently as $1991 .^{20}$ U.S.-based investors are now the largest owners of BP's shares, after investors from the United Kingdom, who have a 70-percent share.

\section{France}

Elf Aquitaine (Elf) was created in 1941 at the initiative of the French government, largely to exploit the Lacq oil and gas field in southwestern France. Elf is France's largest petroleum company. The French government initiated a privatization scheme in 1986 with the sale of 14 percent of Elf to the public. By 1995, the French government's share was reduced to 10 percent. Elf is predominantly an oiland gas-producing company, and most of its production comes from former French colonies among the African countries surrounding the Bay of Guinea. Elf has refining operations in Europe and West Africa. Elf is the seventh largest refiner of crude oil in Europe and seventh largest producer of North Sea crude.

As with BP, global energy privatization has also had a substantial impact on Elf's activities. In upstream, Elf is carrying on operations in such frontier areas as China, Latin America, the Former Soviet Union, Eastern Europe, and Vietnam. Downstream, Elf purchased a refinery in eastern Germany. Elf has also invested in a joint venture (with Russia's recently privatized Lukoil) to expand and upgrade a refinery in eastern Germany. Elf had plans to build a \$2.5-billion dollar refinery in China but later pulled out.

Like British Petroleum, Elf has also engaged in a recent restructuring. Since 1993, Elf has shed roughly 10 percent of its assets and has reduced employment from 94,300 in 1993 to 85,500 in 1995. ${ }^{21}$ Also as with British Petroleum, foreign investors have increased their ownership of Elf in recent years. Foreign investors held 35 percent of Elf's shares in 1995 versus 21 percent in 1992.

TOTAL is France's second largest petroleum company. TOTAL was founded in 1924 at the initiative of the French

\footnotetext{
14"BP agrees $\$ 3.5$ billion deal to develop Algerian gas fields," Financial Times (December 18, 1995), p.1.

${ }^{15}$ British Petroleum, Annual Report on Form 20-F 1994, p. 7.

${ }^{16}$ British Petroleum, Annual Report on Form 20-F 1994, p. 7.

${ }^{17}$ British Petroleum, BP Financial and Operating Information 1991-1995, p. 18.

18"A Very Refined Dilemma," The Financial Times (January 12, 1996), p. 19.

19 "BP to Slim German Gas Stations," The Wall Street Journal (February 16, 1996), p. A6.

${ }^{20}$ British Petroleum, BP Financial and Operating Information 1991-1995, p. 19.

${ }^{21}$ Elf Aquitaine, 1995 Annual Report, pp.3 and 37.
} 
government. Initially, TOTAL consisted largely of Middle East petroleum production interests. The French government's ownership of TOTAL peake the world. British Petroleum is currently 17 percent held at 34 percent but was reduced to 5 percent in 1992. The current French government's five percent interest, coupled with the ownership interests of several large French institutional investors who have long held a substantial stake in the company, would generally indicate a fairly undiluted and stable ownership structure. However, foreign interests (particularly from the United States and the United Kingdom), have increased their ownership from 23 percent in 1990 to 44 percent in 1994.22

TOTAL is the world's 23rd largest petroleum producer and 17th largest refiner. The Middle East (particularly the U.A.E.) accounts for 55 percent of TOTAL's crude oil and natural gas production. Other large producing regions include the North Sea and Indonesia. TOTAL is also active in several frontier areas of petroleum activity. The company currently produces oil and gas in Algeria, Libya, Argentina, and it has a 15-percent interest in Colombia's Cuisiana field. ${ }^{23}$ TOTAL also has upstream operations in Myanmar, Vietnam, Yemen, Nigeria, and Cambodia and has a production-sharing contract with Russia. Downstream, TOTAL is building a refinery in China and studying the construction of one in Vietnam. TOTAL has also opened service stations in Hungary and the Czech Republic.

In contrast to many of the other recently privatized companies, TOTAL's asset base has grown in recent years, by 9 percent since 1992, while employment has increased from 51,139 to 53,536 workers.

\section{Italy}

Italy's ENI was nationalized by Mussolini in the 1930's and is currently Italy's largest industrial company. ENI's privatization has only been very recent. The first 14.7 percent of ENI was sold to the public in 1995 for $\$ 4.1$ billion. ENI has a refining capacity of 933,000 barrels per day and is Europe's third largest refiner. ENI's crude oil production comes primarily from Libya, Egypt, Nigeria, the Congo, the North Sea, and Angola. ENI produces smaller amounts of crude oil in Tunisia and in the United
States. ENI's China production began in 1992, although it currently amounts to only 1 percent of ENI's total crude oil production. Downstream, ENI has recently obtained a 17-percent interest of a consortium (including Conoco, and Royal Dutch/Shell) to reconstruct two Chinese refineries for a total investment of $\$ 480$ million. ENI has also signed an agreement with Russia's Lukoil to jointly develop an oil field in western Siberia. ENI has recently attempted to diversify its ownership overseas. As an example, a large portion of ENI's recent public offerings were dedicated to U.S. investors. ENI has also greatly reduced its payroll in recent years from 124,000 in 1993 to 91,000 in $1995 . .^{24}$

\section{Canada}

In the wake of the 1974 world oil crisis, the Canadian government took measures deemed to strengthen the security of Canada' s energy needs. Petro-Canada was started in 1975 as an instrument of Canada's National Energy Policy, which was designed to encourage domestic ownership of Canadian petroleum resources. According to the plan, Petro-Canada was to provide Canadian policy makers with a better control and understanding of energy developments, or in the parlance of the time to act as a "window" on the world's energy industry. For several years, Petro-Canada enjoyed a privileged position in Canadian energy, being heavily subsidized by the federal government and having exclusive exploration rights to certain Canadian properties. Shortly after its creation, Petro-Canada embarked on an aggressive expansion, acquiring many of the Canadian assets of foreign companies.

After a change in government in 1984, Canada started privatizing Petro-Canada, which had by that time become widely regarded as inefficient, oversized, and laden with debt. After privatization, Petro-Canada began a significant restructuring involving large reductions in operating costs and employment. Since 1990, PetroCanada has reduced its assets by roughly 10 percent, while employment has fallen from 9,806 workers in 1990 to 5,646 in $1995 . .^{25}$ In 1995 , the government's share in Petro-Canada was reduced to 20 percent, which may be sold off in the future. Also, in 1995 Petro-Canada shares were listed on the New York Stock Exchange. ${ }^{26}$

\footnotetext{
${ }^{2}$ TOTAL, 1995 Fact Book, p. 21.

${ }^{23}$ TOTAL, 1995 Fact Book, p. 34.

24"ENI Pays First Dividend for 23 years," Financial Times" (May 11, 1995), p. 27.

${ }^{25}$ Petro-Canada, 1994 and 1995 Annual Report, p.44 and p. 48, respectively.

${ }^{26}$ Petro-Canada 1995 Annual Report, p. 27.
} 
Petro-Canada is the world's 41st largest producer of crude oil. Petro-Canada is Canada's second largest refiner and has a 17-percent share of Canada's refined product market. Petro-Canada is almost exclusively a domestic company, with its natural gas production coming primarily from western regions and its liquids production being largely produced in the east. Petro-Canada has 25percent interest in the \$12-billion Hibernia field project, along with with Mobil ( 33 percent), Chevron (27 percent), Murphy Oil (6 percent), and the Canadian government.

While operating primarily in Canada, in 1996, PetroCanada also started producing oil in Algeria. PetroCanada holds a 70-percent interest in a 1994 discovery of 40-45 million barrels of oil in a field located north of Algiers. $^{27}$

\section{Spain}

Spain's Repsol was founded in 1987, when the Spanish government consolidated various domestic upstream and downstream holdings into a single company. The government sold a 24-percent stake in the company in 1987. The government sold off additional shares in later years, reducing the state's stake to 10 percent in 1996.

Repsol is primarily a downstream company and is Europe's sixth largest refiner. Repsol operates 3,308 exploration and production operations in Dubai, Egypt, and Indonesia. Sixty-one percent of Repsol's production comes from the Near and Middle East, 12 percent from the Far East, and 9 percent from Latin America.
An example of where privatization efforts on two separate continents have converged is Repsol. In 1996, in its largest foray abroad, the company purchased a 38-percent stake in the Argentine company Astra for $\$ 360$ million. Astra is Argentina's fifth largest energy company and is fully vertically integrated with petroleum exploration, production, transportation, and refining operations. ${ }^{28}$ Repsol has also recently purchased refining assets in Peru. ${ }^{29}$ Repsol also has recently attempted to encourage greater foreign ownership. In its most recent sell-off of shares, a portion of the shares were reserved for U.S. investors. ${ }^{30}$

\section{Norway}

Norway's Statoil is the one major OECD-based European petroleum company to remain entirely state-owned. Statoil's genesis is closely tied to the exploitation of North Sea petroleum; it was founded shortly after the discovery of crude oil and natural gas in the North Sea. In recent years, however, Statoil's focus has shifted beyond the North Sea. As a result of recent privatizations, Statoil is currently pursuing exploration and development efforts in China, Azerbaijan, Kazakhstan, Namibia, Nigeria, and Vietnam. ${ }^{31}$ Statoil has recently expanded its retail gasoline efforts into such new markets as Estonia, Latvia, Lithuania, Poland, and eastern Germany. Statoil has also taken a 15-percent stake in a refinery in Malaysia, with the Malaysian state oil company, Petronas, as its partner.

\footnotetext{
27"Petro-Canada Emerging as a Model of State Oil Company Privatization," The Oil and Gas Journal (December 25, 1995$),$ p.22.

28"The Americas: Repsol Group Wins Auction for Refinery," Financial Times (June 12, 1996), p. 31.

29"YPF S.A. Announces Successful Bid for Peru's LaPompilla Refinery," PR Newswire (June 12, 1996).

30"Full Privatization of Repsol A Reality," Platt's Pilgram News (May 15, 1996), p.2.

${ }^{31}$ Statoil, Annual Reports and Accounts 1995, pp. 23 and 24.
} 


\section{Latin American Petroleum Privatization}

Privatization in the Latin American petroleum industry has occurred in an atmosphere of radical economic transformation. In the early 1990's, Latin American countries, almost en masse, embarked on a series of free market-based economic reforms. These policy reforms have in many cases been universal, covering virtually the entire range of economic activities-fiscal, monetary, commercial, trade, and industrial. Central to Latin American economic reforms has been the privatization of a range of formerly state-owned industries, from phone companies to electric utilities to petroleum companies. Legal reform has also been key to privatization efforts in the region, particularly with regards to treating foreign companies equally with domestic companies under the law.

For several reasons Latin American countries were persuaded to privatize national petroleum companies. In addition to obtaining badly needed investment capital and increasing state revenues, privatization is also a means of introducing free market economic reforms. Much of the Latin American petroleum sector had become characterized by bloated payrolls, outdated technology, under investment, and poor provision of services. Further, Latin American state petroleum companies are among the largest petroleum companies in the world (Table 1). As such, their privatization presents a singular opportunity for Latin American governments to raise enormous sums of revenue.

Developments surrounding the numerous 1980's debt crises also had much to do with recent Latin American efforts to privatize their petroleum industries. In particular, these crises greatly hindered the ability of Latin America's state petroleum companies to attract much needed outside capital without providing investors with added incentives and reduced risks. Similarly, the debt crises left many Latin American governments not only in need of raising revenues through privatization to fund other spending priorities. Perhaps more important erratic tax regimes also served to discourage foreign investment in Latin American exploration and production operations.

By 1990, largely due to privatization and other economic liberalization measures, Latin American nations had restored international investor confidence sufficiently that net capital flows into the region increased nearly 250 percent from 1989, growing from $\$ 8.9$ billion in 1989 to $\$ 21.5$ billion in 1990.32 Between 1989 and 1994, U.S. foreign direct investment in Latin America nearly doubled. ${ }^{33}$ Privatization of state-owned industry appears to have played a major role in reversing Latin American capital flight. Approximately 130 Latin American and non-Latin American companies currently have petroleum ventures in Latin America.

That is not to say that political risk has disappeared from Latin America, or that the possibility of future privatization reversals are an unlikelihood. Even though the Peruvian government has achieved some noteworthy success in suppressing its Marxist guerrila insurgency, Shining Path has yet to disappear. The recent uprising in Chiapas, Mexico and Colobia's long-standing war with its insuragency movement underscore some of Latin America's enduring political problems.

The U.S. major oil companies have increased their exploration and development expenditures in Latin America, nearly doubling their expenditure level between 1987 and 1994. With some exception, most Latin American exploration and development activity involving U.S. companies historically has been, and still is, conducted by the majors. ${ }^{34}$ Although amounting to only 6 percent of their total foreign exploration and development spending in 1994, Latin American exploration and development spending by the U.S. majors has grown at twice the rate of

\footnotetext{
${ }^{32}$ World Bank, World Debt Tables 1996, pp. 204-205.

${ }^{33}$ U.S. Department of Commerce, Bureau of Economic Analysis, Survey of Current Business (Washington DC, August 1990-August 1995). Note: The FDI in Latin American calculation excludes Panama, as Panama is frequently used as an offshore depository of funds reinvested in other countries.

${ }^{34}$ One of the most notable exceptions is Maxus, formerly an independent U.S. oil company, which was purchased during 1994 by YPF.
} 
Table 1. Worldwide Company Rankings for the Largest Latin American Petroleum Companies, 1994*

\begin{tabular}{|c|c|c|}
\hline Company (Country) & World Petroleum Production Ranking & World Refining Capacity Ranking \\
\hline Petrobras (Brazil) . . . . . . . . . . . . & 21 & 8 \\
\hline Petroecuador (Ecuador) . . & 48 & 58 \\
\hline Pemex (Mexico) . . . . . . . . . . . . . . & 3 & 10 \\
\hline
\end{tabular}

'Petroecuador's world rankings are based on 1993, not 1994, information.

Sources: Ecuador: Petroleum Intelligence Weekly (December 12, 1994); all others: Petroleum Intelligence Weekly (December 18, 1995).

their exploration and development expenditures in other foreign locales. ${ }^{35}$

However, interest in Latin America has not been limited to.U.S. companies. Latin America's indigenous petroleum companies, foreign multinational oil companies, and some U.S. independents have shown greater interest in developing the continent's petroleum resources. One evidence of the increased level of exploration and development activity in Latin America is the petroleum drilling rig count. The number of drilling rigs operated in Latin America are continuing to increase, as they have yearly since December 1992, reaching 271 in December 1995. ${ }^{36}$ The following sections highlight some of the more important recent foreign company activity due to Latin American petroleum privatization, on a country-bycountry basis, beginning with Argentina, which has undergone the most substantial recent petroleum privatization of any Latin American country.

\section{Argentina}

Argentina embarked on a series of petroleum privatization efforts which began in 1985 and continued through 1993, when the final step in privatization was achieved with the sale of Yacimientos Petroliferos Fiscales (YPF), the state oil company of Argentina. Since the liberalizing of rules governing foreign participation in Argentine oil and gas, the benefits realized from new sources of investment and technology have been substantial and have been responsible for reversing years of declining oil production in Argentina. In terms of crude oil production, YPF is relatively small when compared to such giant Latin American petroleum companies as Mexico's Pemex and Venezuela's Petroleos de Venezuela SA (PDVSA). During 1994, YPF ranked 37th and 50th respectively, in terms of the world's crude oil producing companies and refining companies.

However, despite its size, the privatization of YPF represents one of the most significant and successful of all Latin American state-oil company privatizations. In 1990, Argentine crude oil production stood at 483,000 barrelsper-day, a level less than that produced a decade earlier. However, by 1995, Argentine production reached more than 700,000 barrels per day, and 1 million barrels of crude are expected to be produced daily in the year $2000 .{ }^{37}$ During 1994, when drilling activity was largely deteriorating in all other regions, the opposite was true in Argentina, which experienced a 66-percent increase in its crude oil and natural gas rig count between 1993 and $1994 .{ }^{38}$

An influx of private investment largely accounts for the turnaround in Argentine petroleum. For instance, U.S. direct investment in Argentina's petroleum industry has climbed from $\$ 452$ million in 1989 to $\$ 773$ million in $1994 .{ }^{39}$

Foreign companies were involved in Argentina's petroleum industry for several years prior to privatization. In 1994, the Argentine subsidiaries of the U.S. companies

${ }^{35}$ Energy Information Administration, Form EIA-28, Financial Reporting System.

36"International Rig Count," Oil and Gas Journal (January 15, 1996), p. 62.

37"Foreign and Private Investment Needed," World Oil, Vol. 216, No. 8 (August 1995), p. 45ff.

38"International Rig Count," Oil and Gas Journal, 93 (February 20, 1995).

${ }^{39}$ U.S. Department of Commerce, Bureau of Economic Analysis, Survey of Current Business (Washington, DC, various issues August 1990-August 1995). 
Amoco and Occidental accounted for 7 percent and 3 percent, respectively, of Argentina's crude oil production. ${ }^{40}$ Exxon and Royal Dutch/Shell (Shell Oil Company's Netherlands/UK parent) also have owned major Argentine refineries for several years.

Privatization is responsible for more recent foreign ventures. In 1993, YPF announced that it would modernize its flagship La Plata refinery with technical assistance from Chevron. In 1992, the U.S. company Enron led a joint venture that won the concession to own and operate one of the two Argentine national gas transmission systems divested by Argentina when the state gas company, Gas del Estado, was privatized. ${ }^{41,42}$ Drilling companies from the United States entered Argentina with Pride Petroleum Services' 1996 purchase of Argentina's largest drilling and workover rig company, Quitral-Co. S.A.I.C., for approximately $\$ 140$ million. ${ }^{43}$ In 1996, the former Spanish state oil company, Repsol, purchased a 38-percent controlling interest in Argentina's fifth-largest energy company and fourth-largest crude oil producer, Astra. ${ }^{44,45}$

In addition to encouraging foreign direct investment, privatization also may be responsible for a more outward-looking Argentine oil industry. YPF entered the ranks of major multinational oil companies with its acquisition of Maxus Petroleum in 1994. Maxus, a U.S. independent crude oil exploration and production company, has operations in Asia and the United States, in addition to Bolivia, Colombia, Ecuador, and Venezuela. Other recent actions by YPF also indicate an attempt to broaden its operations overseas:

- In 1994, YPF signed a contract with YPFB, the Bolivian state oil company, to explore for hydrocarbons near the Bolivian-Argentine border. YPF expects to invest $\$ 50$ million in the project. ${ }^{46}$ YPF also entered into a partnership in the early 1990s with Brazil's state oil company, Petrobras, to develop gas reserves for possible export to Brazil. ${ }^{47}$ YPF recently engaged in exploration projects in Chile, Peru, and offshore Louisiana. ${ }^{48}$

- YPF recently expanded their marketing operations in Bolivia, Chile, and Peru. ${ }^{49}$

\section{Mexico}

In contrast to Argentina, efforts at privatization of the Mexican petroleum industry and the opening of new business opportunities to foreign companies have been negligible. Electric power and natural gas distribution projects appear to provide the greatest opportunity for foreign investment. ${ }^{50} \mathrm{Mexico}$ 's recent privatization of large nonenergy public firms along with the signing of the North American Free Trade Agreement created some initial optimism among foreign companies that petroleum privatization would ensue. ${ }^{51}$ In 1991, Chevron expanded its small representative office in Mexico City in the hope of signing a service deal to gain access to Mexican oil. Similarly, Amoco, Mobil, and Texaco showed an interest in Mexican investment. ${ }^{52}$ Both Occidental and Royal Dutch/Shell's U.S. affiliate, Shell Oil, recently made equity investments in petrochemical operations formerly belonging to Pemex, the Mexican state petroleum company and the world's third-largest producer of crude oil and the tenth-largest refiner in terms of crude oil refining capacity.

However, despite some initial efforts, reform in Mexican petroleum has faltered. Foreign participation in the exploitation of Mexico's petroleum resources has long been a particularly sensitive matter in Mexican politics.

\footnotetext{
40" Privatization of State Company Catalyzes Argentine Oil Industry," Oil and Gas Journal, 93 (February 13, 1995), p. 46.

${ }^{41}$ Petroleum Intelligence Weekly (December 14, 1992).

42"Privatization of State Company Catalyzes Argentine Oil Industry," Oil and Gas Journal, 93 (February 13, 1995), p. 52.

${ }^{43}$ Durgin, Hillary, "Pride agrees to buy Argentina driller," The Houston Chronicle (March 19, 1996), p. 3.

${ }^{44}$ Bowen, Sally, "Companies and Finance: The Americas: Repsol group wins auction for refinery," Financial Times (June 12, 1996 ), p. 31.

${ }^{45}$ Goldman, Joe and Peter Zipf, "Mobil Circling Around a Stake in Astra," Platts Oilgram News (May 24, 1996), p. 1.

4h"Bolivia Signs New Trade and Cooperation Accords with Chile and Argentina," Chronicle of Latin American Economic Affairs (October 20, 1994).

47" Privatizations Open Exploration and Production Opportunities," World Oil (August 1994).

${ }^{48}$ YPF, 1994 Annual Report, p. 3.

49YPF, 1994 Annual Report, p. 2.

san Mexico opens northern cities for natural gas distribution," Energy Report, 24 (May 27, 1996) and Kummer, Kristie, "U.S.-Mexico natural gas issues," Gas Energy Review, 24 (April 1996), p. 6.

${ }^{51}$ The Economist (August 21, 1993). These sales raised over $\$ 20$ billion.

${ }^{52}$ Petroleum Intelligence Weekly (June 10, 1991).
} 
Although, substantial early development of the Mexican petroleum industry was accomplished by British and U.S. petroleum companies, ${ }^{53}$ nationalization of all foreign petroleum assets on March 18, 1938 abruptly ended foreign activity in Mexican Petroleum. ${ }^{54}$ Foreign participation in oil and gas exploration, production, and refining is still proscribed by the Mexican constitution, which allows only Pemex to engage in these activities. So far, the only substantive reform measures include a restructuring of Pemex's operations (along with substantial reductions in employment), an attempt to sell several chemical units and other non-core operations, and an increased reliance on foreign drilling contractors. Pemex also has undertaken joint ventures abroad. Pemex's downstream operations have focused on reconfiguring and modernizing its refineries to both increase product output and address environmental concerns. Despite refinery upgrades, Pemex's refinery capacity is less than current product consumption, leading to increased product imports and further refinery construction. Pemex also replaced some of its domestic shortfall by gaining a 50-percent share in Shell Oil's Deer Park, Texas, refinery. ${ }^{55}$

\section{Venezuela}

Venezuela is the most recent Latin American country to have nationalized its petroleum industry a point wellknown by several of the world's leading petroleum companies. Several of these companies thought they were undercompensated for their petroleum assets absorbed during 1975 by Venezuela's nationalization process. ${ }^{56}$ Although Venezuela's liberalization of its petroleum industry is more substantial than Mexico's, it still falls short of Argentina's complete privatization. Venezuela approved a new profit-sharing concessionery program in July 1995 under which private domestic and foreign companies may bid for joint ventures with Petroleos de Venzuela (PDVSA). PDVSA is Venezuela's state oil company and the world's fifth-largest producer of crude oil and the fourth-largest refiner. Heavy oil investment 'carries tax concessions, as do enhanced-oil-recovery projects, which lower the statutory tax rate to 34 percent from 70 percent..$^{57}$ Further, on January 7, 1996, Venezuela's congress passed a law allowing larger new projects with substantial exports and foreign investment to retain export earnings abroad. ${ }^{58}$ Although privatization of PDVSA does not seem likely, company president Luis Giusti recently noted that, "it would be very healthy to have 15 percent [of shares] in the capital market. ${ }^{159}$ Venezuela also auctioned exploration rights to eight tracts but received no bids for two other tracts. ${ }^{60}$

The most notable result of Venezuela's opening its petroleum industry is its awarding of the first exploration license to foreigners since its nationalization twenty years ago. The initial license was awarded to a consortium of Veba (Germany), Mobil, and Nippon Oil (Japan), which outbid 11 others, including the second-place consortium of Exxon and Royal Dutch/Shell, for a western onshore oil field. ${ }^{61}$ Other significant projects opened to foreign companies include the $\$ 5.6$-billion Cristobal Colon LNG export project of a consortium including Exxon and Lagoven, a PDVSA affiliate. This venture is the first foreign ownership of Venezuelan hydrocarbon reserves since the 1975 oil law that nationalized the petroleum industry and created PDVSA was passed. ${ }^{2}$ However, the venture was suspended, awaiting higher natural gas prices. Another project is a joint venture between Conoco (United States) and Maraven (a PDVSA affiliate) to produce heavy oil, which will then be upgraded and refined into products at Conoco's U.S. refineries. ${ }^{63}$

Other foreign companies are either discussing joint ventures, or have formed joint ventures and are awaiting congressional approval to proceed, including:

- ARCO and Corpoven, a PDVSA affiliate, are discussing a heavy oil production and upgrading project.

\footnotetext{
${ }^{53}$ Yergin, Daniel, The Prize (New York: Simon Schuster, 1991), pp. 229-233.

${ }^{54}$ Yergin, Daniel, The Prize (New York: Simon Schuster, 1991), pp. 271-279.

55"New President Pledges Economic Liberalization," Petroleum Economist, Vol. 61, No. 11 (November 1994), p. 17.

${ }^{\text {S6}}$ Yergin, Daniel, The Prize (New York: Simon Schuster, 1991), pp. 648-650.

${ }^{57}$ Huber, Ed, "Opportunities in the Americas: Pipeline projects open Latin markets," Oil and Gas Investor, 16 (February 1996), p. 2.

58"Venezuela Seen as Next Boom Town for Project Finance Deals," Bank Letter, 20 (January 22, 1996), p. 2.

${ }^{59}$ Marquez, Humberto, "Venezuela: Debate on Oil Privatization Goes On, and On ...," Inter Press Service (May 7, 1996) and Katsouris, Christina,

"PDVSA chief mulls sale of minority stake in firm as country reforms petroleum sector," The Oil Daily, 46 (April 24, 1996 ), p. 1.

${ }^{\infty}$ Chatterjee, Pratap, "Oil and Gas Industry Gears Up for Latin America Bonanza," Inter Press Service (March 5, 1996).

${ }^{61 " G e r m a n-U . S .-J a p a n e s e ~ t e a m ~ w i n s ~ o i l ~ e x p l o r a t i o n ~ l i c e n s e ~ i n ~ C a r a c a s, " ~ D e u t s c h e ~ P r e s s e-A g e n t u r ~(J a n u a r y ~ 22, ~ 1996) . ~}$

${ }^{62} \mathrm{See}$, for example, Yergin, Daniel, The Prize (New York: Simon Schuster, 1991), pp. 648-650.

${ }^{63}$ "Conoco-Maraven combine to tap Orinoco crude," Oil and Gas Journal, 93 (November 20, 1995), p. 41.
} 
- Chevron agreed to do a feasibility study of a base lubricant manufacturing plant joint ven ture with Citgo, PDVSA's U.S. affiliate, and Maraven,

- Conoco is a member of a consortium awaiting congressional approval of a joint venture with the PDVSA affiliate Bitor to produce and market the boiler fuel orimulsion.

- Enron is studying the feasibility of a joint venture with Maraven to produce petrochemicals.

- Mobil is studying the feasibility of two different heavy crude upgrading joint ventures, one with Maraven and the other with Lagoven.

Foreign companies also are undertaking ventures governed by service contracts with PDVSA and equity ventures that do not require congressional approval. Chevron and Maraven have created a heavy crude production joint venture with an operating contract, while Mobil is a member of a consortium to evaluate exploration and development opportunities in the new areas opened for exploration by Venezuela during 1995. Mobil bought 50 percent of Nacional de Grasas which operates the largest lubricants blending plant in Caracas and is the largest lubricants company in Venezuela. ${ }^{64}$ Canadian Occidental has formed a joint venture to bid on exploration and development contracts PDVSA is expected to offer during 1995. Occidental signed a 20-year agreement with Maraven to increase oil production.

Although Venezuela's privatization efforts have lagged those of other Latin American countries, PDVSA has long been an internationally oriented petroleum company. For instance, PDVSA's U.S. subsidiary, Citgo, is the largest retail marketer of gasoline in the United States. ${ }^{65}$ In terms of U.S. refining capacity, PDVSA ranks third among foreign-owned companies behind Royal Dutch/Shell and . British Petroleum. ${ }^{6}$ PDVSA also owns substantial refining operations in Europe and the Caribbean.

\section{Brazil}

During 1994, Brazil's national government began considering possible privatization plans in order to generate badly needed investment capital. Revision of the constitutional prohibition of foreign involvement in upstream oil and gas to allow foreign joint ventures with Petrobras, Brazil's state oil company and the world's 21st-largest company in terms of oil production and the eighth-largest refiner, also is being considered. However, full privatization of Petrobras, which is chiefly owned by the federal and state governments of Brazil as well as by private enterprises and individuals through local stock market shares, has been categorically rejected. ${ }^{67}$ Nonetheless, some erosion of Petrobras' monopoly may be achieved by a proposal to the Brazilian congress that would compel Petrobras to compete with private companies for new exploration areas, leaving Petrobras with 3-year concessions to all known exploration areas and to any new discoveries by Petrobras. ${ }^{68}$

Little foreign activity has ever occurred in Brazilian upstream petroleum. The only foreign commercial discovery occurred during the 1970's and was made by the Shell Oil affiliate Pecten. The discovery was an offshore natural gas field. Petrobras' substantial reserves and refining capacity are a tempting target for potential buyers, but, until further efforts at privatization are made, few opportunities exist for foreign companies in Brazil.

The most significant project currently underway in Brazil by a non-Latin American company is Tenneco Gas's construction of the Brazilian part of the Bolivia-Brazil pipeline and some other natural gas projects. ${ }^{69}$ PDVSA and Petrobras also are negotiating a refinery joint venture. ${ }^{70}$

\section{Colombia}

Legal reforms to allow privatization of Colombian energy resources are underway. Colombia's government, noting

\footnotetext{
${ }^{64}$ Mann, Joseph, "Mobil returns to Venezuela," Financial Times (April 4, 1995), p. 27.

${ }^{65}$ National Petroleum News Market Facts '95 (mid-June 1995), p. 35.

${ }^{66}$ Energy Information Administration, Petroleum Supply Annual 1993, DOE/EIA-0340(93) (Washington, DC, June 1994), pp. $110-114$.

67"Energy in Latin America; Even Oil is Growing Less Sacred," The Economist (June 1, 1996), p. 63.

${ }^{69}$ Music, Kimberley, "Brazilian energy minister offers plan for regulation of newly opened sector," The Oil Daily, 45 (December 21,1995$)$, p. 1.

${ }^{6}$ Platts Oilgram News (August 13, 1993).

${ }^{70}$ The Oil Daily (December 21, 1995), p. 1.
} 
the importance of oil exports, is taking steps to improve the attractiveness of oil and gas exploration and development to foreign investors. The first step was the elimination of a hydrocarbon production tax. Previously, Colombia had one of the highest rates of petroleum taxation in the world. ${ }^{71}$ Recent changes in its tax laws have reduced both some loopholes and some fees on investment in the hope of enticing more foreign investment the oil and gas remittanice tax ${ }^{72}$ may be reduced to 7 percent, which is the rate charged other Colombian industries. ${ }^{73}$

The most significant energy privatization contemplated is the sale of the state's 50-percent share of the Carrejon coal mine. However, reports of privatization of some or all of the state oil company Ecopetrol, the 40th-largest producer of petroleum and 57th-largest refiner in the world, have been denied by the country's energy minister. ${ }^{74}$

Recent privatization efforts created numerous new foreign investment opportunities in Colombia. British Petroleum discovered 2 billion barrels of proved reserves in the Cusiana and Cupiagua oil fields, which will be developed by a joint venture with Triton Energy (United States), Total (France), and Ecopetrol. This joint venture also will spend $\$ 2$ billion upgrading Colombia's pipelines to transport the additional production. Another joint venture, which includes Ecopetrol, British Petroleum, Total, Triton Energy, and others, will build an oil export pipeline from the Cusiana Field. British Petroleum also purchased Maxus' 53-percent share of a block adjacent to the Cusiana Field, augmenting the 10-percent share it already held.

Recent foreign company activity in Colombia's petroleum industry include the following:

- Amoco's Colombian subsidiary has obtained a 60 percent interest in a 45 -million cubic feet natural gas field and plans to drill a second well in this field during 1995. Chevron and Exxon also have ongoing petroleum exploration and development operations.
- Enron and Ecopetrol have a joint venture to develop a 200-megawatt oil-fired electricity generating plant. Enron also leads a consortium that will build, own, and operate a 200megawatt cogeneration plant in Cali.

- Exxon has a 50-percent share in the soon-tobe-privatized Carrejon coal mine.

- Conversely, Texaco reduced its Colombian heavy oil production by selling five heavy oil fields during 1994. Texaco plans to expand its natural gas operations in Colombia through the addition of a second offshore platform during 1996 and plans to engage in new exploration in the Middle Magdalena Valley.

\section{Ecuador}

Ecuador is following the more typical course of Latin American countries by privatizing most state-owned nonenergy assets and selected energy assets. The state oil company Petroecuador, which was the 48th-largest producer of petroleum and the 58th-largest refiner in the world during 1993, and other strategic sectors will be privatized through awarding concession contracts instead of direct sale or the sale of equity shares. ${ }^{75}$

During 1995, five production-sharing contracts were signed following the seventh round of contract solicitations. Among the companies awarded contracts were the U.S. companies Oryx and Triton and the Kuwaiti Sante Fe Minerals and Energy. ${ }^{76}$ Amoco and Mobil have a joint venture to operate a 25 -year concession in a production block in the Amazon Basin. Oryx has taken over the operation of an oilfield joint venture with Ecopetrol, which currently produces 8,000 barrels per day. Oryx also leads a consortium that won a 25-year production-sharing concession for an oil field block.

\footnotetext{
${ }^{71}$ World Oil (August 1994).

${ }^{72} \mathrm{~A}$ remittance tax is a withholding tax assessed on proceeds earned by a company's activities in some foreign country. The expectation is that the proceeds will be repatriated. Often the remittance tax may be avoided by reinvesting the proceeds in the host country. In the case of Colombia, if the reinvestment is maintained for at least ten years, then the tax is forgiven entirely. See Neira-Mejia, Luis Carlos and Ricardo Munoz-Mejia, "Colombia," International Financial law Review (October 1994), pp. 16-20.

${ }^{73}$ Oil and Gas Journal (November 20, 1995), p. 30.

${ }^{74}$ Reuters Financial Energy News (September 6, 1994).

75" Getting in Step; Latin American Governments Turn to Private Sector for Infrastructure Needs," Latin Finance, Vo. 58 (June 1994), p. 58ff.

76"Ecuador Investment: FDI Falls $11.5 \%$ to $\$ 470 \mathrm{~m}$ in 1995," EIU Views Wire (January 23, 1996).
} 


\section{Peru}

New oil legislation was passed in August 1993, leading to a return of foreign investment and the eventual privatization of the state oil company, Petroperu. Perupetro, a state agency and not to be confused with Petroperu, was established to promote, negotiate, and administer exploration and production contracts, for which Petroperu must compete with private firms. Recently, Peru's government improved the country's legal framework, improved its national economy, and reduced terrorism, all of which activities were welcomed by foreign investors. The privatization activities of Petroperu was anticipated to begin in July 1995, but was delayed due to widespread unrest and rioting. However, the first Petroperu assets were sold in June 1996. ${ }^{77}$ Recent estimates are that privatization of Peru's state oil company will raise $\$ 3$ billion.

Several foreign investments recently have been made in Peru. In June 1996, Pluspetrol, an Argentine petroleum company was awarded exploration and development rights for Peru's northern oilfields. ${ }^{78}$ ARCO received an exploration and production contract for a northern tract in December $1995 .{ }^{79}$ A consortium led by the French petroleum company Elf Aquitaine was awarded an exploration and production contract for an eastern tract in September $1995 .^{\circ 0}$ Chevron received approval in June 1995 to begin exploration and development in the large Camisea natural gas field in Peru's southeastern region, while the Coastal Peru Ltd, the Peruvian affiliate of a U.S. company, signed an exploration and development contract with Petroperu for a tract in central Peru. Also in 1995, Occidental won a 20-year development contract for a production tract in a commercially viable field. In August 1994 Mobil's Peruvian subsidiary was authorized to begin exploration of a tract in the southern Peru. Mobil is also a partner in a 30-year exploration and development joint venture in northwest Peru. Mobil and Royal Dutch/Shell have agreed to develop the giant Camisea natural gas field in southeastern Peru through a joint venture. Mobil and Shell Oil are negotiating a contract with Petroperu for exploration and development rights to two blocks that surround two of the major Camisea fields. ${ }^{81}$ Downstream, Petroperu sold 60 percent of the equity in its largest refinery (102,000 barrels per day) to a consortium led by Repsol, which included Mobil and YPF, outbidding PDVSA's Maraven affiliate. ${ }^{82}$ Mobil also bought several gasoline stations from Petroperu.

\section{Bolivia}

Bolivia is privatizing its public industries in an innovative way, selling a controlling 50-percent share of each public company to a single buyer who provides the company with capital for expanding its productive capacity. The remaining 50 percent share is to be deposited in a pension fund for all Bolivians. ${ }^{83}$ Bolivia is also attempting to pass a new hydrocarbon law that will attract foreign investment.

However, plans to privatize the state oil company Yacimientos Petrolifieros Fiscales Bolivianos (YPFB) have been frustrated by opposition from Bolivia's confederation of workers. ${ }^{84}$ The intent is to divide YPFB into two upstream companies, two downstream companies, and one natural gas transmission company before capitalizing the resulting companies. ${ }^{85}$ The financial and production requirements to qualify to bid for one of the companies resulting from the division of YPFB ostensibly exclude the private Bolivian petroleum companies, causing them to join the labor unions in opposing the privatization process. ${ }^{86}$ Chevron is negotiating to fund a seismic program on its share of an exploration block. ${ }^{87}$ Enron and YPFB have a $\$ 400$-million joint venture to construct the

\footnotetext{
7 "Peru's La Pampilla Refinery Sold for $\$ 180.5$ million," Reuters (June 11,1996 ).

${ }^{78}$ Bowen, Sally, "Companies and Finance: The Americas: Repsol group wins auction for refinery," Financial Times (June 12, 1996), p. 31.

${ }^{7}$ Katsouris, Christina, "ARCO signs E\&P contract with Perupetro as firm recovers from tender offer flop," The Oil Daily, 45 (December 11, 1995), p.

80" Group Led by Elf Signs Peru Oil, Gas Deal," Reuters (September 8, 1995).

${ }^{81}$ Oil and Gas Journal, 93 (January 16, 1995).

82."YPF S.A. Announces Successful Bid for Peru's La Pampilla Refinery," PR Newswire (June 12, 1996).

${ }^{83}$ Bowen, Sally, "News: The Americas: Sell-off initiative heading for trouble," Financial Times (April 16, 1996), p. 3.

${ }^{84}$ Financial Times (April 16, 1996), p. 3.

${ }^{85}$ Kielmas, Maria, "Latin America restructures," Petroleum Economist, 62 (September 1995), p. 40.

${ }^{86}$ Kielmas, Maria, "Latin America restructures," Petroleum Economist, 62 (September 1995), p. 41.

${ }^{87}$ Chevron Corporation, Press Release (June 28, 1995).
} 1. 
350-mile Bolivian portion of the Bolivia-Brazil natural gas pipeline. ${ }^{88}$ Exxon completed seismic studies. ${ }^{89}$ Mobil has an interest in a production block and is negotiating concessions for two adjoining tracts. ${ }^{90}$ Texaco and Mobil are members of a consortium with an exploration and development concession. ${ }^{91}$

\section{Trinidad and Other Latin American Countries}

Trinidad's recent privatization of its energy industry has led to numerous investments in its natural gas industry (and electricity generation). Amoco has discovered a substantial natural gas field and is planning the construction of a large liquefied natural gas facility. ${ }^{92}$ ARCO, Broken Hill Properties (Australia), British Gas, Chevron, 'Deminex (Germany), ENI (Italy), Enron, Exxon, Premier Oil (UK), Repsol (Spain), Royal Dutch/Shell,' Texaco, Unocal, Veba (Germany), and Wintershall (Germany) all have petroleum investments in Trinidad.

A few privatization-related projects exist in other Latin American countries. In El Salvador, Coastal plans to build and operate a $\$ 100$-million power plant, which is the first privately-owned plant in El Salvador. A Coastal affiliate will supply fuel to operate the plant. ${ }^{93}$ Also, Texaco has a 40-percent share in a production block in Paraguay.

\footnotetext{
${ }^{88 " E n r o n ~ S i g n s ~ B o l i v i a n ~ P i p e l i n e ~ D e a l, " ~ L a t i n ~ A m e r i c a n ~ E n e r g y ~ A l e r t ~(D e c e m b e r ~ 20, ~ 1994) . ~}$

89"Peru Action Simmering Despite Privatization Delays," Oil and Gas Journal (August 7, 1995).

${ }^{90}$ Oil and Gas Investor, 15 (October 1995), pp. 94-95; and "Bolivia: Thirty-five register for YPFB," Privatization International (October 1, 1995).

91 "Foreign and Private Investment Needed," World Oil, 216 (August 1995), p. 45.

92" Gas Outlays to Rise in Trinidad/Tobago," Oil and Gas Journal (July 15, 1996), p. 26.

${ }^{93}$ The Coastal Corporation, Annual Report 1995, p. 29.
} 


\section{Chapter 4. Privatization in Socialist and Former Socialist Nations}

\section{Russia}

The fall of the Soviet Empire ushered in an era of mass political, legal, and economic reforms. In Russia, the move to a market economy has involved the privatization of much of Russia's industry. Russia's large petroleum sector is currently going through the privatization process, though initially on a more limited scope and at a slower pace than other industries. A November 1992 presidential decree established vertically integrated oil companies from former oil-producing associations of the Former Soviet Union (FSU). The gas sector, however, was to remain intact under the gas monopoly Gazprom.

Like the breakup of Standard Oil in the United States during the beginning of this century, the FSU's oil production monopoly was separated along geographic lines, combining regional oil production associations with refineries and product distributors, and transforming them into integrated joint (public and private) stock companies (see Box entitled "Russia's New Petroleum Industry, p. $20^{\prime \prime}$ ). The final restructuring and consolidation of the industry's assets occurred in 1995 under a subsequent presidential decree that gave rise to the current structure of eleven vertically integrated oil companies. ${ }^{94}$ Their estimated size in reserves and production allows them to compete with the world's major petroleum companies; eight of the eleven integrated Russian oil companies are ranked in Petroleum Intelligence Weekly as among the "World's Top 50 Oil and Gas Companies for 1994."195

The partial privatization of the Russian oil industry has consisted of two stages. ${ }^{96}$ The first stage, which ended in June 1994, was the commercialization of state enterprises into joint stock companies and the selling of shares through vouchers, with ownership limited to workers and Russian citizens. Thirty-eight to forty-five percent of the shares in the companies are required to remain in government hands for at least three years, after which the government share may be reduced. The privatization process is currently in the second phase, which opens ownership to foreign investors. During this stage, remaining shares will be distributed in one of two ways: 1) the disbursement of blocks of shares to investors in exchange for their commitment to maintain employment levels and to make future contributions to the enterprise and 2) the sale of shares for cash.

In 1995, under the shares-for-cash proposal, the Russian government implemented a shares-for-loans scheme, whereby large blocks of government shares in certain joint stock companies (which included five of Russia's oil giants) were auctioned to a group of Russian commercial banks for cash. The successful bidders are required to hold the shares in trust for a maximum of three years in return for providing loans to the government to reduce its budget deficit. At any time, the government can buy back its shares. However, because the affected shares are to be temporarily managed by the bidder awarded the shares, a controversy has arisen over the possibility of corruption entering the bidding process. Consequently, all future auctions have been terminated and the results of last year's auction are being challenged. These challenges have arisen from many parties, including government factions, the public, commercial banks, and both managers and owners of the former joint stock companies. Some of these challenges are currently in court.

Most of Russia's new oil companies are operating as regional monopolies. Others, like Lukoil and Rosneft, are using their size and influence to expand beyond their

\footnotetext{
94"Oil Industry Privatization, Russia Style," Petroleum Economist (February 1996), p. 4.

95"Petroleum Intelligence Weekly Ranks the World's Top 50 Oil Companies," Petroleum Intelligence Weekly - Special Supplement Issue (December 18, 1995).

${ }^{96}$ Energy Information Administration, Country Analysis Briefs 1994 (May 1995), p. 59.
} 


\section{Russia's New Petroleum Industry}

* Lukoil, formed in 1993, is the largest of Russia's newly integrated oil companies, with estimated reserves of around 8 billion barrels. $^{\text {a }}$ It has four refineries with a total refining capacity of 470,000 barrels per day. In 1995, the company produced 1.1 million barrels per day. ${ }^{b}$

* Yukos is the second largest producer, with reserves of around 7.3 billion barrels. The company produced 719,000 barrels per day in 1995. From the company's three refineries, with a combined capacity of 653,000 barrels per day, 1994 refining throughput was 363,490 barrels per day. $^{c}$

* The third largest producer is Surgutneftegas, with reserves estimated at almost 5.5 billion barrels. The company has one refinery with a refining capacity of 386,000 barrels per day. 1995 production averaged 669,000 barrels per day while refining throughput was 243,000 barrels per day.

* Sidanko, with reserves estimated at just over 6.5 billion barrels, has three refineries. The company is the largest of Russia's refiners, with a capacity of 790,000 barrels per day. Crude production for 1995 averaged 459,000 barrels per day, and refining throughput averaged 400,000 barrels per day.

* The newest company, Tyumen Oil Company, produced 456,000 barrels per day in 1995 . The company owns one refinery, with a capacity of 360,000 barrels per day. In 1995, its refining throughput averaged 148,000 barrels per day. Its reserves are estimated at 6.5 billion barrels.

* The Siberian Oil Company (Sibneft) owns one refinery and has reserves estimated at 2.9 billion barrels. Production in 1995 averaged 409,000 barrels per day for the company, while refining throughput was 330,000 barrels per day. Its refining capacity is 524,000 barrels per day.

* The company Slavneft has two refineries and production of 266,000 barrels per day in 1995 . One refinery is located in Belarus. The combined refinery capacity is 670,000 barrels per day.

* Rosneft was once the Russian state holding company but was turned into an integrated company during the restructuring in the second half of 1995 after many of its producers, refineries, and product distributors were parceled out to other companies. The company will continue to remain solely responsible for the government's share under production sharing agreements drawn up with foreign companies. The company now has three refineries, with 477,000 barrels per day combined capacity. Reserves are estimated at just under 3.3 billion barrels. Production averaged 254,000 barrels per day while refining throughput was 97,700 barrels per day in 1995.

* The three smaller companies - Eastern Oil Company, Orenburg Oil Company (ONAKO), and Komitek - each has one refinery. In 1995, Eastern Oil Company's production averaged 224,000 barrels per day, while refining throughput was 110,000 barrels per day. ONAKO's production averaged 144,000 barrels per day while its refining throughput was 88,000 barrels per day. Komitek's production averaged 89,000 barrels per day while its refining throughput was 54,000 barrels per day.

\footnotetext{
${ }^{\text {a }}$ Reserves and capacity listed for companies: "Petroleum Intelligence Weekly Ranks the World's Top 50 Oil Companies," Petroleum Intelligence Weekly-Special Supplement (December 18, 1995). It should be noted that different estimates of petroleum reserves for FSU companies vary considerably. Further, these reserve estimates may not conform with U.S., or Securities and Exchange Commission, definitions.

${ }^{\mathrm{b}}$ Production numbers for all companies: Nefte Compass, Vol.5, No.4 (January 25, 1996), p.7.

c'Russian Refining Shows Signs of Revival, Needs Investment," Oil and Gas Journal (March 25, 1996), p. 51.
} 
borders to other countries, and compete with the world majors. For example, in 1994, Rosneft and two of its subsidiaries at the time purchased a 24-percent interest in the planned Leuna refinery in eastern Germany. ${ }^{97}$ Lukoil also has stakes in several production-sharing agreements and joint ventures in former Soviet Republics and is pursuing interests in Europe.

\section{Overhauling the Industry}

Foreign capital and technology are needed in the oil sector to help stop the decline in production, which peaked at 12.5 million barrels per day in 1987 and fell to 6.2 million barrels per day by $1995 .^{98}$ The decline in production, which only recently has begun to level off, is attributed mainly to management and production inefficiencies, outdated and inadequate infrastructure, lack of investment, declines in domestic demand, low domestic prices, an inability to export, and uncertainty surrounding property. right issues.

Downstream, the rebuilding of Russia's petroleum infrastructure is also being delayed by the slow pace of foreign investment. Most of Russia's 29 refineries are old, inefficient, and in need of modernization. The total operational capacity of Russia's refineries is 6.6 million barrels per day with a utilization rate of under 60 percent. ${ }^{99}$ Russia's Ministry of Fuel and Energy has begun to restructure the refinery sector, with plans to build several refineries in Russia and to upgrade existing refineries. The ministry hopes to increase throughput by 17 percent to 4.2 million barrels per day, in the year 2000. ${ }^{100}$ Costs of modernizing and expanding the industry during the 19952000 period are estimated at $\$ 7$ billion. ${ }^{101}$

\section{Gazprom, the World's Gas Company Giant}

One company, Gazprom, dominates the Russian natural gas industry and is the world's largest gas company, with reserves of 848 trillion cubic feet. ${ }^{102}$ In 1994, Gazprom produced 20,160 billion cubic feet. Consisting of 10 production associations, Gazprom produces over 90 percent of Russian gas and owns over 70 percent of the country's gas reserves. ${ }^{103}$

In 1993, Gazprom was converted into a state-owned joint stock company, and then began to be privatized in April 1994. As in the oil industry, shares were divided among Gazprom employees and other domestic investors, while 40 percent of its shares is to remain in government hands for at least three years. Nine percent of Gazprom's stock has been set aside for foreign ownership. The sale of shares (even between private individuals) requires Gazprom's approval.

In contrast to the oil sector, Gazprom has been relatively successful at maintaining output, which is mainly in western Siberia, where over 90 percent of Russia's natural gas is produced. ${ }^{104}$ However, much investment capital is needed for field development and for rehabilitation of Gazprom's extensive network of pipelines, almost 90,000 miles. Currently, nonpayment from Gazprom's major customers, Russia's electric utilities, and the republics of the FSU has developed into a crisis. Revenues that would have been used for projects have been diverted to subsidize the electric utilities, since cutting off supplies to the utility companies is forbidden by law. Of the FSU republics, the Ukraine owes the largest sum of money. However, the Ukraine has some unique leverage since Russian gas accounts for about 60 percent of Europe's gas imports, of which over 90 percent runs through the Ukraine. Exports to Europe are one of Gazprom's most secure sources of cash. Attempts to reduce gas deliveries to the Ukraine for nonpayment have failed because the Ukraine began to siphon gas destined for Europe to offset the shortfall. ${ }^{105}$

Currently, since transport costs are not taken into account in establishing price, gas prices remain uniform across Russia, creating further inefficiencies in the gas industry.

\footnotetext{
${ }^{97}$ Eales, R, and Bourne, J., "Elf Reduces Its Stake in Enterprise Oil, Share Sale Retains J-V," Platt's Oilgram News, Vol. 72, No. 215 (November 4, 1994), p. 1.

${ }^{98}$ Energy Information Administration, International Petroleum Statistics Report (June 1996), pp.6 and 8.

99"'Russian Refining Shows Signs of Revival, Needs Investment," Oil \& Gas Journal (March 25, 1996), pp. 48, 51-52.

100" Russian Refining Shows Signs of Revival, Needs Investment," Oil \& Gas Journal (March 25, 1996), pp. 48, 51-52.

101 "Russian Refining Shows Signs of Revival, Needs Investment," Oil \& Gas Joumal (March 25, 1996), pp. 48, 51-52.

${ }^{102}$ Reserves and production:"Petroleum Intelligence Weekly Ranks the World's Top 50 Oil Companies," Petroleum Intelligence Weekly, Special Supplement Issue (December 18, 1995).

${ }^{103}$ Energy Information Administration, Country Analysis Briefs: 1995 (January 1996).

${ }^{104}$ Energy Information Administration, Country Analysis Briefs: 1995 (January 1996).

105"Robber Baron," Forbes (September 11, 1995), pp. 13-16.
} 
Some critics have recently called for, regulating the industry. Some would even like to see Gazprom dismantled, but no serious efforts have been made so far to break up their monopoly.

Even prior to privatization, Gazprom has had relationships with foreign companies, both in and outside the FSU. Currently, Gazprom is working on various projects with European and Asian countries that could eventually lead to the establishment of an intricately connected gas network system throughout these regions. Further, Gazprom holds an interest in a German natural gas transmission operation with its German joint venture partner, Wintershall.

\section{Foreign Investment}

The breakup of the Soviet Union and the move toward a market-driven economy are seen by many foreign investors as offering new exploration and production opportunities to one of the wiorld's largest petroleum producing areas outside Saudi Arabia. ${ }^{106}$ Russia first began to open the door to foreign investment in its petroleum industry through joint ventures. Foreign participation was not allowed in the initial stage of the privatization of assets. The second phase, however, did open up opportunities for foreign investors to take equity stakes in Russia's petroleum industry. ARCO became the first foreign company to buy an equity stake of up to 6 percent in the Russian oil firm Lukoil, paying $\$ 250$ million for convertible bonds.

Joint ventures in upstream activities remain the main vehicle for foreign investment. Joint ventures are a way for Russia to gain access to capital and efficient, costsaving technology and for foreign companies to gain a foothold in Russia. Oil and gas production from joint ventures has been increasing rapidly over the last few years, contrary to the trend for total Russian output. However, the joint ventures currently operating in Russia's oil and gas sector contribute only a fraction to overall production. Joint venture production increased by 39 percent in 1995 to 420,000 barrels per day, comprising 7 percent of total Russian output. ${ }^{107}$

Foreign joint exploration and development projects in Russia are mostly within known fields located in three of
Russia's five largest producing regions. The regions include western Siberia, the Arctic Region, and the Russian Far East. In western Siberia, Occidental is operating the Vanyoganneft joint venture, one of its two enhanced oil recovery projects (the other is located in the Komi Republic). Amoco has a 50- percent interest in the Priobskoye field. In the Arctic Region, the largest production-sharing agreement being negotiated is the Timan Pechora Company (TPC), led by Texaco (with a 30percent ownership share) and including Exxon (30 percent), Amoco (20 percent), and Norsk Hydro (20 percent) ${ }^{108}$ The joint venture includes the exploration and development of 1.8 million acres located in the Timan Pechora Basin (with 11 huge oil fields) north of the Arctic circle. Also located in the Timan Pechora Basin is Conoco's joint venture, Polar Lights, the first oilfield developed and brought on stream by a western company. In the Russian Far East, Sakhalin Island is the site where three agreements have been negotiated so far. Sakhalin I is being developed with the Exxon-Sodeco consortium, Sakhalin II is being developed with the MMMMS consortium (Marathon-USX, McDermott, Mitsui, Mitsubishi, and Royal Dutch/Shell), and Sakhalin III has been divided and will be developed by two different groups-two blocks are being developed by Exxon and one block is being developed by Mobil and Texaco.

Twelve production sharing agreements have reached an advanced state of negotiation, and await finalization. However, uncertainty surrounding jurisdiction over resources, licensing, and taxation, have made many oil companies withhold an estimated $\$ 60$ billion of investment until legislation that provides adequate investment guarantees can be passed. For example, Amoco, the Timan Pechora Company, and the companies operating in all three of the Sakhalin agreements have chosen not to begin their projects until the passage of appropriate legislation. The long-awaited Oil and Gas Law-which was signed into law in January 1996-was supposed to provide that framework. However, modifications that were made to get the law passed did not fully provide the guarantees desired by foreign investors. Some provisions that foreign companies find objectionable are: 1) the requirement to have parliamentary approval for fields in areas defined as "strategic" and for production sharing agreements not awarded by tender, 2) the Russian government's right to modify conditions of a production sharing agreement if

\footnotetext{
${ }^{106}$ Saudi Arabia began outproducing the FSU in 1993.

${ }^{107}$ Nefte Compass, Vol. 5, No. 4 (January 25, 1996), p. 7.

${ }^{108}$ Energy Information Administration, Country Analysis Briefs: 1995 (January 1996).
} 
"major economic changes" occur during the term of the agreement, 3) a provision that subsequent individual laws will determine which fields can be developed under production sharing agreements, and 4) the lack of recourse available to foreign investors to resolve disputes in an international tribunal. ${ }^{109}$ Thus, the Oil and Gas Law (as passed) is considered a major setback by many of the companies and has forestalled their major investment plans. ${ }^{110}$ Other barriers to foreign investment include a high tax burden in Russia. The absence of reliable transportation and access to foreign markets are other hurdles faced by both Russian and foreign companies. Access had been curtailed severely due to uncertainty surrounding changing export restrictions, which include quotas, requirements to export through holders of official special exporter licenses, and high export taxes. Investors faced a further barrier when the Russian government instructed joint ventures to supply the bulk of their oil to former Soviet Republics, where payment problems have arisen.

Once market conditions improve in Russia, substantial infrastructure investments will be needed before the decline in production can be reversed. ${ }^{111}$ Physical constraints on the infrastructure, particularly the inefficient and outdated pipelines run by the state pipeline monopoly Transneft, plague both foreign and domestic companies, Furthermore, Russia's vast pipeline system has seen a change in flow patterns, resulting in supply disruptions. New pipelines are needed and existing pipelines must be repaired and upgraded. Plans to expand the system are being given top priority, but not much can be done until investments increase.

At present, ambitious plans to develop Russia's petroleum resources have faltered largely due to uncertainties surrounding oil and gas laws, changing tax regimes, and the ability (both physically and legally) to export crude oil to international markets. If economic reforms continue and political stability improves, Russia could rival the Mideast as a source of crude oil exports. To entice foreign investment capital, Russia must offer investors the opportunity to earn acceptable returns on their investments. To do so, Russia must implement laws that protect property rights, provide access to foreign markets, liberalize prices, and offer fair taxation. Further, Russia must reduce the twin destructive influences that widespread corruption and organized crime have come to have over legitimate commerce.

\section{Caspian Region}

\section{The Pipeline Debate}

The Caspian Sea shelf is considered one of the largest sources of petroleum outside the Persian Gulf and Russia.

The region's largest producers are Azerbaijan and Kazakhstan. The key to foreign investment in these two Caspian nations is obtaining secure export routes. Lack of a secure means of transporting Caspian Sea oil and gas to world markets has been an impediment to foreign investment. Until foreign investors can rely on access to markets, investment in the Caspian region's huge petroleum potential will remain small.

The lack of pipeline access is limiting production in the region. Russia is demanding participation in the region and derives its influence through its control of the only existing pipelines in the region. Also, disputes with Russia over the legal status of the Caspian Sea are being negotiated but they could still disrupt matters. Russia is seeking to push through new regulations stipulating that no offshore resource developments should be undertaken without the compliance of all surrounding states. Russian oil and gas companies, like Lukoil and Gazprom, have succeeded in acquiring stakes in large Caspian projects. Some foreign investors believe it is necessary to bring Russian participants into their projects to guarantee access to markets. In the meantime, various alternative routes have been proposed; however, until they become a reality, Russia will maintain its dominance in the area.

Many western companies would like to see multiple routes due to political instability in the area, to provide alternative access to markets for international companies involved and to diversify European energy supplies. However, the political climate for those interested in the Caspian region has delayed the development of proposed pipeline routes. The two most promising routes include pipelines that will link Caspian production fields with the Black Sea and, thereby, the Mediterranean Sea and European markets. The first proposed pipeline project is the Caspian Pipeline Consortium's (CPC) \$1.2-billion project to refurbish and connect existing Russian pipelines to the Black Sea port of Novorossisk via Chechnya. However, the proposed project was additionally delayed when Chevron and others did not support CPC's pro-

\footnotetext{
109"Yeltsin Signs PSA Law As TOTAL Carries The Torch," Nefte Compass, Vol. 5 No. 1 (January 4, 1996), pp. 1-2.

"10"Reign of the Self-assured Lords; Russian Petroleum Industry; Industry Overview, "Petroleum Economist (March 1995), p. 33.

"II"Reign of the Self-assured Lords; Russian Petroleum Industry; Industry Overviews," Petroleum Economist (March 1995), p. 33.
} 
posals on financing and limited ownership of the 900-mile Caspian Sea oil pipeline. As a result, the original threemember CPC consortium (consisting of Russia, Kazakhstan, and Oman) negotiated and recently signed a new accord for a joint protocol to restructure the CPC, inviting Chevron and seven other international energy companies to join them, with an offer of 50-percent combined ownership. The consortium has awarded the following shares: Chevron (15 percent), Lukoil (12.5 percent), Rosneft ( 7.5 percent), Mobil ( 7.5 percent), British Gas (2 percent), Agip (2 percent), Oryx (1.75 percent), and Kazakhstan's Munaigaz (1.75 percent). ${ }^{112}$ The foreign companies will be responsible for financing the pipeline.

The second pipeline project arose from an agreement between Russia and the 12-member Azerbaijani International Oil Consortium (AIOC). ${ }^{113}$ The agreement between Russia and this largely western consortium gives these companies permission to use Russian pipelines to export oil due to be produced by the end of 1996 through two alternative export pipeline routes from Baku. One route is north through the CPC pipeline, which crosses Russia, and the other route is west through a pipeline to be built across Georgia. Both alternatives end at the Black Sea. The agreement is waiting final approval from the Russian parliament.

Turkey is undertaking its own plans to build a pipeline. The planned project is a $\$ 1.8$-billion project to build a 1,047-mile oil pipeline linking the Caspian fields through Georgia to the port of Ceyhan in the eastern Mediterranean. ${ }^{114}$ These plans however, have given rise to concerns over the environmental damage increased oil traffic through the Dardanelles would cause. One other option involves connecting pipelines in the FSU Caspian region to pipeline networks in Iran, although this latter option has met with strong opposition from the United States and Israel.

\section{Azerbaijan}

Political instability associated with repeated changes of government has limited reform in Azerbaijan, the oldest, and once major, oil-producing region of the FSU. However, Azerbaijan is now opening its large reserves, estimated at 10 billion barrels, ${ }^{115}$ to foreign investment through joint ventures with the State Oil Company of Azerbaijan (SOCAR). Foreign investment is needed to restructure and modernize the outdated and inefficient infrastructure inherited from the FSU. The Caspian pipeline and territory disputes extend into Azerbaijan, which is also in need of an outlet to export markets.

The two largest international joint venture projects include the Shakh Deniz prospect, with reserve estimates of 4-5 billion barrels, and the 1-billion barrel Karabakh prospect. ${ }^{116}$ The Shakh Deniz prospect is an \$8-billion project between SOCAR and the AIOC. The 30-year project is to explore the three large offshore Caspian fields of Azeri, Chirag, and Gyuneshli. Initial oil production is expected sometime in late 1996, with peak production estimated at 700,000 barrels of oil per day by 2010 . In addition, France's Elf Aquitaine has recently signed a production-sharing agreement with SOCAR for a separate onshore/offshore block in the Shakh Deniz area.

The second largest Azerbaijan joint venture project is being explored by the Caspian International Petroleum Company, consisting of Pennzoil, Agip, Lukoil, and SOCAR ${ }^{117}$ The $\$ 1.7$-billion project includes the exploration, development, and production of the Karabakh prospect in the Azerbaijan sector of the Caspian Sea.

In addition, Exxon and SOCAR signed an agreement in June 1996 for two Caspian sea exploration blocks, while Occidental, Chevron, Mobil, and Unocal are actively seeking opportunities in offshore Azerbaijan.

Downstream provides another potential target for foreign investment. The state-owned monopoly, SOCAR, has 2 refineries with a refining capacity of 441,808 barrels per day. ${ }^{118}$ Foreign investment will be necessary to help finance the modernization proposal to upgrade the refineries, but current investment plans have been delayed due to the previously-cited pipeline dispute and debt owed by the refineries for past deliveries.

\footnotetext{
112"New Pact for Kazakh-Russian Oil Pipeline," New York Times (April 29, 1996), p. 8.

${ }^{113}$ The AIOC consists of British Petroleum/Statoil, Amoco, Exxon, Pennzoil, Unocal, Lukoil, Itochu, Ramco, Delta-Nimar, Turkey's TPAO, and SOCAR. "Filling the Vacuum," Russian Petroleum Investor (May 1996), p. 44.

114"Russia, Turkey Vie for Control Over Caspian Sea Oil Riches," The Christian Science Monitor (April 24, 1996), p. 19.

115"Caspian Sea Attractive But Controversial," Petroleum Economist (January 1996), p. 36.

"16"Once-Major Oil Province Looks to Caspian for its Comeback; Caspian Sea," Petroleum Economist (March 1996), p. 8.

117"Once-Major Oil Province Looks to Caspian for its Comeback; Caspian Sea," Petroleum Economist (March 1996), p. 8.

118" Worldwide Refining Report," Oil and Gas Journal (December 18, 1995), p. 57.
} 


\section{Kazakhstan}

After Kazakhstan became independent from Russia in 1991, the country hoped for rapid development of its Kazakhstan's recoverable reserves of crude and condensates, which are 21.9 billion barrels and 81.2 trillion cubic feet of gas and are mainly located in the Caspian Sea. ${ }^{119}$ Probable reserves amount to 51.3 billion barrels of oil and 264.9 trillion cubic feet of gas. ${ }^{120}$ However, Kazakhstan has no direct access to world markets. Further, Kazakhstan suffers from an under-developed and inefficient petroleum pipeline infrastructure. As a consequence, production of one of the world's largest petroleum areas has remained largely unexploited. Stateowned companies in Kazakhstan currently account for most of the 1995 average production of 420,000 barrels per day, which could more than double by the year 2000 if there were guaranteed access to markets. ${ }^{121}$

Restructuring the oil industry included setting up the state holding company Munaigaz to coordinate all oil industry activities. ${ }^{122}$ Prior to an international tender last month, there were seven producers and three refineries under Munaigaz control. There has been a proposal to end Munaigaz' monopoly, following the Russian example, by creating vertically-integrated oil companies. In what is being called a test case for privatization, Kazakhstan held an international auction for shares in two of its producers, Aktyubinskneft and Yuzhneftegas. These companies have combined proven reserves of more than 2 billion barrels, and also own the 150,000-barrels-per-day Chimkent refinery. Samson Investment Company, a U.S. firm, won a 100-percent stake in the Kazak producer Yuzhneftegas. Samson submitted a joint bid with the local investment firm Munainvest, fending off a single challenge from Canada's Hurricane Hydrocarbons. The Swiss Trading Company, Vitol, won the tender for a 90-percent stake in Kazak's Chimkent oil refinery, but the terms have not. been settled. ${ }^{123}$ Kazak companies' large debts, non-productive assets, and lack of transparency made investors cautious. Companies also were concerned about the many preconditions associated with the awarding of shares, particularly the required pledges for investment, social guarantees, payment of old debts, and environmental liability. ${ }^{124}$
Thus far, in Kazakhstan, privatization has mainly been limited to joint ventures, with many of the republic's most attractive fields being acquired by international companies. In 1993, Chevron began a long-term investment in Kazakhstan at one of the largest fields in the world, the Tengiz oil field with 6 billion barrels of proven reserves. The 40-year joint venture between Chevron ( 50 percent) and the government-owned producer Tengizmunaigaz could produce 700,000 barrels of crude per day and bring in $\$ 20$ billion in investment. However, lack of a reliable export route has led production to be cut to 60,000 barrels per day, even though current capacity is 120,000 barrels per day. The high hydrogen sulfide content of the field has also posed potential transportation and marketing problems. Chevron, which has spent over $\$ 1$ billion already, has delayed expansion plans until the pipeline issue is resolved.To help finance its share of the project, Kazakhstan sold half of its 50-percent stake to Mobil in early 1996 for $\$ 1.1$ billion. ${ }^{125}$ In 1993, seven foreign companies, including the British Petroleum/Statoil partnership, Royal Dutch/Shell, British Gas, Total, Agip, and Mobil, signed a contract for seismic testing in Kazakhstan's area of the Caspian Sea region, in exchange for the right to select two blocks for further exploration and development and the right to bid on the remaining blocks. ${ }^{126}$ In addition, Mobil (50 percent) and three Kazak partners are exploring the western Atyrau and northwest Aktyubinsk regions in the \$80-million, 25-year, TulparMunai venture. In 1994, Oryx Energy signed two agreements to explore Kazakhstan's eastern Caspian Sea area. One involves the exploration of a large block in western Kazakhstan, in which Exxon later bought a 50percent stake. The other is a 50-50 joint venture with two Kazak partners to develop the Arman field in the north Buzachi Peninsula.

Despite large gas reserves, development of natural gas resources also has been limited due to inadequate infrastructure. The country currently is a net importer of natural gas. The only existing export route for natural gas is a Gazprom pipeline that runs through Russia. This has led British Gas and Agip, who have exclusive rights to negotiate for reserves of the Karachaganak field, estimated to hold 16 trillion cubic feet of gas and 2.4 billion barrels of condensate, to bring in Gazprom as a partner

\footnotetext{
119"Pipeline Problems Block Oil Sector Development," Petroleum Economist (April 1996), p. 10.

120"Pipeline Problems Block Oil Sector Development," Petroleum Economist (April 1996), p. 10.

12l"OGJ Worldwide Production," Oil and Gas Journal (December 25, 1995), p. 43.

122."Pipeline Problems Block Oil Sector Development," Petroleum Economist (April 1996), p.12

123 "Samson Blows Away Hurricane, Wins Bid For Kazak Producer," The Oil Daily (June 7, 1996), p. 5.

124"Kazakhstan Sets Up Test Case for Oil Privatization," Financial Times (April 30, 1996), p. 25.

${ }^{125}$ "Mobil Takes 25 Percent Piece of Tengiz Field," Platt's Oilgram News (April 18, 1996), p. 1.

126"Pipeline Problems Block Oil Sector Development," Petroleum Economist (April 1996), p. 11.
} 
with a 15-percent stake. However, a production-sharing agreement has not been finalized and Gazprom has yet to put up its share of the equity.

The pipeline issue also is holding up downstream projects. Kazakhstan has three refineries, with a refining capacity of 393,611 barrels per day, ${ }^{127}$ that are in need of Russian crude deliveries, lower demand, and limited access to international export markets have reduced refining throughput and delayed modernization plans to expand capacity.

\section{Eastern Europe}

\section{Economies in Transition}

Eastern European countries are also undergoing major political and economic structural reforms. Previously under strong central government control, they have begun to decentralize their economies, transforming them through various programs consisting of industry restructuring and privatization. Former state-owned firms are being internally restructured, shifting from public ownership with state control to various types of private ownership. To address the need of potential investors for clearly defined property rights, each country has attempted to develop viable legal structures, contract laws, regulatory systems; capital markets, trade policies, and domestic bond and stock markets. However, while investment has not been as forthcoming as anticipate-due to the slow pace of reform-many countries are proceeding with various degrees of privatization, such as oint ventures. Foreign investment is higher in the countries where reform has made the most progress, namely the Czech Republic, Hungary, and Poland. The diversity of reform among the countries in eastern Europe-which includes voucher sales, direct sales, and National Investment Funds is related to how each country addresses the issue of sovereignty over strategic national assets.

As in the FSU, the Communist regimes left eastern European countries with bloated and inefficient hydrocarbon industries that suffered from decades of neglect, outdated technology, heavy debt, and environmental problems. Unlike Russia's large reserves, eastern Europe produces little oil and natural gas-only Romania has a sizeable endowment of reserves. The eastern European countries are dependent on imports, mainly from Russia, to meet primary energy demand.

The condition of eastern European refining is similar to that of upstream petroleum. All eastern European countries have refinery industries (Table 2). Most are badly in need 'of restructuring and upgrading. The petroleum marketing sector is the fastest growing sector in eastern Europe's energy industry, partly due to the introduction of foreign competition in many countries.

Thus far, most energy enterprises are still publicly-owned and government-run. However, to meet the petroleum needs of those economies where privatization efforts are strongest, private ownership is beginning to emerge. For

Table 2. Eastern Europe Petroleum Statistics for 1995

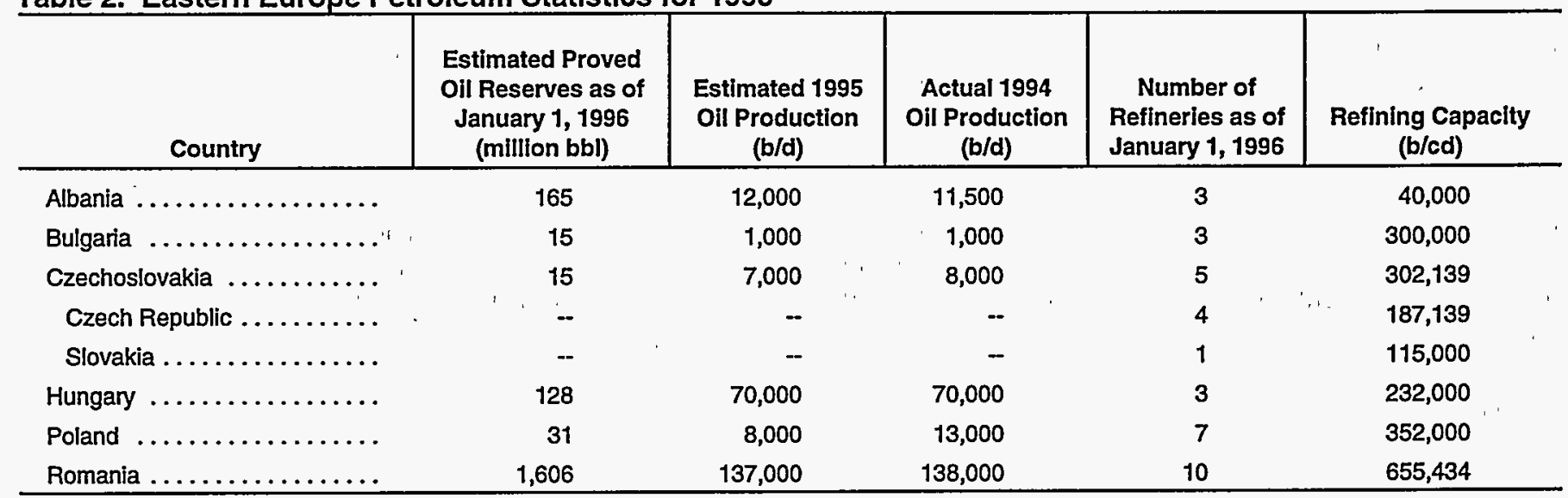

Sources: Reserves \& Production: "Special Worldwide Production," Oil and Gas Joumal, December 25, 1995. Refining: "Special Worldwide Refining," Oil and Gas Joumal (December 18, 1995), pp. 48-9.

127"Worldwide Refining Report," Oil and Gas Journal (December 18, 1995), p. 57. 
example, Hungary has sold an 18.8-percent stake in its vertically integrated petroleum company, MOL. ${ }^{128}$ The Czech Republic merged its two largest refineries and sold 49 percent to $I O C$, a western consortium.

Eastern Europe under central planning was virtually closed to foreign investors. Foreign capital could play a pivotal role in helping diversify energy supplies, increase energy efficiency through modernization, and improve the environment. Although foreign direct investment has increased in these areas, inflows remain modest. Foreign direct investment has been slow to materialize due to continuing macroeconomic instability and insufficient institutional reforms. To date, most foreign investment has been through joint ventures.

Each country has a unique socioeconomic context, causing variation in the transition process across all countries in the region. Different ownership structures are emerging under different privatization schemes. Reform has continued, even in the face of economic decline and decreasing production since the fall of communism and the beginning of efforts to move to market economies. Only now are these countries beginning to recover economically, spurred by exports and increasing domestic demand.

\section{Albania}

After decades of neglect, Albania began to reform its oil and gas industry by establishing a state-owned oil and gas company and allowing joint ventures with foreign companies, mainly in the form of production-sharing agreements. The national oil and gas company, Albpetrol, was established in 1992. It currently controls 46 energy and petroleum-related enterprises. ${ }^{129}$

Foreign oil companies were initially restricted to offshore drilling. ${ }^{130}$ Since legislation opened up onshore concessions to foreign investors in 1993, there have been two international onshore licensing rounds. In the first round, foreign companies were invited to bid for three oilrecovery enhancement projects. ${ }^{131}$ Included in the second international onshore licensing round was the concession for two onshore blocks not awarded in the first licensing round and one offshore block in the Adriatic Sea, which previously had been relinquished by Agip of Italy. ${ }^{132}$ Over the past four years, $\$ 100$ million has been invested by foreign oil companies, with a further investment of $\$ 60$ million expected during 1996. ${ }^{133}$

\section{Bulgaria}

Bulgaria's economy, which was one of the Eastern European economies most closely patterned after the Soviet system, is one of the most energy-intensive in the world. Although Bulgaria generates 40 percent of its electricity from nuclear energy, the country is also heavily dependent on coal. ${ }^{134}$ The country's dependence on coal has created severe environmental problems.

Due to constant shifts in government, economic reform in Bulgaria has been among the slowest in eastern Europe. ${ }^{135}$ Heavy subsidies and government-controlled prices still exist in the energy sector. Privatization of the energy sector was excluded from the 1995 privatization program, although the country's two largest refineries, Neftochim and Plana,were placed in a separate category reserved for enterprises that require special government approval prior to privatization. Even so, Bulgaria was the first eastern European country to offer petroleum exploration concessions to western countries. ${ }^{136}$ Three international auctions - in 1991, 1993, and 1995 - have been held so far. Eight companies received oil exploration licenses in the first, while no licenses were awarded in the second. Final results of the third have yet to be announced. Production results have been mixed. In addition, foreign filling stations have been allowed to compete with the dominant state-owned oil and petroleum products distributor, Bulgargas.

Bulgaria is trying to use its unique position (connecting supply from the countries of the Commonwealth of Independent States and from the Middle East with western European markets) to reestablish links with Russia's newly integrated oil companies. However, the

\footnotetext{
128"Eastern Europe - Reluctant to Sell," Petroleum Economist, Vol. 62, No. 9 (September 1995), p. 22.

129"Eastern Europe - Reluctant to Sell," Petroleum Economist, Vol. 62, No. 9 (September 1995), p. 22.

130"Albania Aims to Accelerate Oil and Gas Exploration," Financial Times (November 29, 1995), p. 57.

131" Eastern Europe - Reluctant to Sell," Petroleum Economist, Vol. 62, No. 9 (September 1995), p. 22.

132"Albania Aims to Accelerate Oil and Gas Exploration," Financial Times (November 29, 1995), p. 57.

133"Albania Aims to Accelerate Oil and Gas Exploration," Financial Times (November 29, 1995), p. 57.

134"Eastern Europe - Reluctant to Sell," Petroleum Economist, Vol. 62, No. 9 (September 1995), p. 23.

135"Eastern Europe - Reluctant to Sell," Petroleum Economist, Vol. 62, No. 9 (September 1995), p. 23.

136"Eastern Europe - Reluctant to Sell," Petroleum Economist, Vol. 62, No. 9 (September 1995), p. 23.
} 
pipelines establishing' these links' have had oil transit disrupted by the United Nations' embargo against Iraq and the outbreak of war in the former Yugoslavia. In May 1995, Gazprom and Bulgargas set up a joint-venture company to control the flow of Russian gas through Bulgaria, build gas' supply systems, invest in Bulgaria's 2,000-kilometer gas network (linked to Russia via two pipelines running through Ukraine and Romania), and market Russian gas to other countries. ${ }^{137}$

\section{Czech Republic}

Separated from Slovakia on January 1, 1993, the Czech Republic has been an aggressive economic reformer with foundations of a market economy firmly in place. On November 28, 1995, the Czech Republic became the first post-Communist state in eastern Europe to sign an agreement to join the Organization for Economic Cooperation and Development (OECD), becoming the group's 26th member. ${ }^{138}$

Like Bulgaria, the country produces little energy, except for coal. The country is a net importer of all energy supplies and is largely dependent on Russia for its energy imports. Even though the Czech Republic is considered a lead reformer in eastern Europe, the country has yet to finalize plans on how it will restructure its oil and gas industry.

Even though the Czech Republic is considered a lead reformer in eastern Europe, the country has yet to finalize plans on how it will restructure its oil and gas industry. Currently, the gas distributor Transgas remains under full state control. Initially, with only one pipeline-the Friendship line from Russia-and with refining badly in need of upgrading, the Czech Republic has sought foreign investment to help it fully integrate with Europe and to reduce its dependency on Russian oil. In March 1996, the Czech Republic will acquire alternative sources of oil with the opening of its second crude pipeline. The pipeline to Germany was built under an agreement between the two countries.
Downstream, the Czech government consolidated operations prior to privatization. The two largest Czech refineries, Chemopetrol and Kaucuk, were merged to form Czech Refineriès, with the state's 51-percent interest being retained by Unipetrol-a newly established holding company, which currently owns the remaining petrochemicals industry, and Benzina, the partially privatized petroleum distributor. ${ }^{139}$ In November 1995, the largest refinery privatization in eastern Europe and the Former Soviet Union took place when the Czech government signed a \$672-million agreement to sell the remaining 49percent state-owned share in Czech Refineries to IOC, a consortium including Royal Dutch/Shell, Agip, and Conoco.

\section{Slovakia}

Slovakia is largely dependent upon imported oil and gas. Slovnaft, the country's third largest petroleum company, is the industry's refiner and petrochemical company. By the time of Slovakia's separation with the Czech Republic, Slovnaft was already 20 -percent privatized. ${ }^{140}$ In 1995 , to increase its attractiveness as an investment prospect, Slovnaft bought a 51-percent stake in Benzinol, which controls 60 percent of the retail gasoline market and is a major Slovnaft customer. The government is negotiating with Agip of Italy to buy an additional 34-percent stake in Benzinol. The company recently offered additional equity through a global-depository-receipt offering to raise money for a modernization program. ${ }^{141}$

There is uncertainty regarding the pace of structural reforms. Privatization virtually came to a halt in late 1994, and decisions to dispose of state property have been reversied on several occasions. In July 1995, the "Golden Egg Law" was passed. It listed dozens of firms that will notbe privatized or in which the state will keep a right of veto over key decisions. ${ }^{142}$ Utilities will remain under permanent state control, and the state will keep decisive influence on the oil refiner Slovnaft and the energy company Nafta Gbely. Also passed was a law that scrapped the final wave of voucher privatizations and

137"Eastern Europe - Reluctant to Sell," Petroleum Economist (September 1995), p. 22.

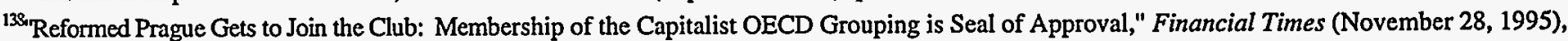

p. 2.

139."Eastern Europe-Reluctant to Sell," Petroleum Economist, Vol. 62, No. 9 (September 1995), p. 23. "Czech Refinery Deal, Long in Making, Finally Signed," Platt's Oilgram News, Vol. 73, No. 221 (November 16, 1995), p. 6.

${ }^{140}$ "Eastern Europe-Reluctant to Sell," Petroleum Economist Vol. 62, No. 9 (September 1995), p. 23. "Czech Refinery Deal, Long in Making, Finally Signed," Platt's Oilgram News, Vol. 73, No. 221 (November 16, 1995), p. 6.

141"Eastern Europe-Reluctant to Sell," Petroleum Economist (September 1995), pp. 23-4.

${ }^{142}$ Vacova, T. "Slovakia's 'Golden Eggs' Law May Deter Investors," The Reuter European Business Report (July 14, 1995). 
replaced them with a direct sale method. However, foreign participation has been the lowest since the inception of privatization in 1992, with only 3 out of 232 foreign companies accepting direct sales offers between January and August 1995. ${ }^{143}$

\section{Hungary}

Hungary has embarked on one of the most ambitious of privatization schemes. Hungary is the only country in the region to build a vertically integrated company, the Hungarian Oil and Gas Company (MOL). ${ }^{144}$ MOL was founded in 1991 and is Hungary's largest company. Its utility segment ranks as one of Europe's top 15 oil and gas utilities. Currently, Hungary produces about one-fourth of its oil and half its natural gas needs. MOL accounts for 90 percent of the nation's oil and gas production, refining capacity, and reserves. ${ }^{145}$ Political uncertainty in the Ukraine and continuing problems with pipeline access to the Adriatic has jeopardized secure energy supplies. As a consequence, MOL has sought to diversify its gas supplies and to develop oil and gas reserves abroad by acquiring exploration licenses in the Former Soviet Union, Algeria, and Tunisia. In 1994, MOL and OMV, Austria's state oil company, agreed to jointly construct a 120-kilometer pipeline linking Baumgarten, Austria, and Gyor, Hungary, providing Hungary with its first access to western gas. ${ }^{146}$ Germany also has agreed to sell western natural gas to the company. ${ }^{147}$

In addition, MOL is seeking joint venture partners in oil and gas exploration and production. After several postponements, the first bids for domestic exploration were offered in 1994, with the five concessions being awarded to a consortium of Blue Star, Coastal, and affiliates of Occidental and Mobil. ${ }^{148}$

Before privatizing, MOL began restructuring. In May 1995, the assets of Mineralimpex (previously Hungary's gas importing monopoly and, at the time, the country's second hydrocarbons trader after MOL) were transferred to MOL. ${ }^{149}$ Both MOL and its new Mineralimpex subsidiary have been cutting staff, and MOL expects a profitable $1995 .{ }^{150}$

In June 1995, the Hungarian parliament passed the longawaited Privatization Act. After a promising beginning and several false starts, the first wave of energy sector privatization went forward with a "combined offer" during October/November 1995. Companies in western Europe, Russia, and the U.S. competed for stakes in Hungary's oil, gas, and electricity businesses. In November 1995, Hungary sold an 18.8-percent stake in MOL, the first time ownership in an eastern European oil company had been sold. ${ }^{151}$

Foreign investment and competition have been visible in the retail sector for some time. Two decades ago, Shell Hungary was allowed its first franchised filling station through a local agreement with the state trading company, Interag. ${ }^{152}$ By 1993, the company was 100 -percent Shell-owned. By 1994, Shell had 15 percent of all service stations and held a 20-percent share of product sales. MOL still leads the retail gasoline market in Hungary, with 50-percent of the service stations and a 35-percent share of product sales. Other major gasoline marketers in Hungary include Mobil, Exxon, Conoco and Total, with each holding about a 5-percent share of the country's gasoline market. ${ }^{153}$

\section{Poland}

Since 1989, Poland has undergone several changes in government, a fact that has delayed privatization. ${ }^{154}$ In 1995, after a three-year delay, Poland finally took the first serious steps to privatize major state-owned enterprises by launching their long-awaited mass privatization initiative. Instead of a voucher system, Poland has set-up 15

${ }^{143}$ Janowski, T. "E. Europe Faces Main Privatisation Tasks," The Reuter European Community Report (January 17, 1996).

144"MOL Issue Priced at Bottom of Equity Range-Equity Offerings," Financial Times (November 22, 1995), p. 35.

145" Privatizing in Hungary: A Door Reopens," The New York Times (October 17, 1995), p. D1.

146"Hungary's Privatization Program Advances," Oil and Gas Journal (September 11, 1995), p. 26

${ }^{147}$ "Eastern Europe-Reluctant to Sell; Special Report: National Energy Companies-A New Era; Industry Overview," Petroleum Economist (September 1995), p. 22.

148" "Eastem Europe-Reluctant to Sell; Special Report: National Energy Companies-A New Era; Industry Overview," Petroleum Economist (September 1995), p. 22,

149"MOL Announces Nine Months Results," PR Newswire (December 15, 1995).

150" Privatizing in Hungary: A Door Reopens," The New York Times (October 17, 1995), p. D1.

151 "Privatizing in Hungary: A Door Reopens," The New York Times (October 17, 1995), p. D1.

152"Hungary Prepares for Gas Sale with Privatization Law," East European Energy Report (May 22, 1995).

153" "Hungary Petroleum Privatization Limited by Economic Concerns," Oil and Gas Journal (July 4, 1994), pp. 24, 27-8.

${ }^{154}$ Janowski, T. "Feature-Poland Sees No Big Change in Privatization Course," The Reuter European Business Report (February 26, 1996). 
National Investment Funds (NIFs). The NIFs' are joint stock companies that were allocated 60-percent shares in 44 industrial companies created from the privatization of state enterprises.

The government is currently deciding on how to restructure and privatize the Polish oil and gas indistry: ${ }^{155}$ Poland intends to rapidly modernize its energy industry, but to date no part of its energy industry has yet been privatized. As a result of legislation passed in 1995, privatization in most energy sectors, including coal mines, oil and gas sectors, and energy distributors, requires parliamentary approval. Poland's modest oil onshore production is in the hands of the Polish Oil and Gas Company (POGC) and offshore production is performed by the joint stock company Petrobaltic. The POGC, one of the last fully integrated, state-owned monopoly petroleum enterprises in Europe, has sole responsibility for exploration and production of both gas and oil, gas imports, transmission, storage, and distribution. The government has tentatively adopted a restructuring plan for the POGC intended to transform it (in stages) into separate, independent companies for exploration, drilling, production, transmission and distribution. The government is considering limiting foreign ownership in such privatized major companies to minority stakes.

The country produces only around 1 percent of its domestic oil needs. ${ }^{156}$ Russia supplies Poland with 60 percent of its natural gas. However, unlike other eastern European countries, Poland is less dependent on Soviet crude oil due to its Baltic Sea ports. In 1991, licensing for gas exploration was opened to domestic and foreign companies. Since then, two licensing auctions have been held. Several foreign companies have participated, including Exxon, Shell, British Gas, and Amoco.

Downstream, seven refineries organized as joint stock companies supply the bulk of the country's product needs. Under preliminary government plans, they are to be merged with CPN, the state-owned gasoline distribution network. Shares in refineries are to be offered separately to strategic investors. Minority shares (of 20 to 30 percent) in refineries may go on sale under a plan to consolidate and later privatize the oil sector. Poland's second largest oil refinery, Rafineria Gdanska S.A., has signed a contract with Chevron to use the company's licensed technology in a planned \$400-million upgrading. ${ }^{157}$ Plock and Gdansk, the two main refineries, are embarking on modernization programs worth more than $\$ 1.5$ billion.

Polish authorities have introduced competition in gasoline wholesaling and retailing, and both foreign and domestic suppliers are entering the market. 'Foreign investment in the Polish gasoline retailing business has been modest so far due to uncertainties. Norway's Statoil and Finland's Neste have 11 gasoline stations each, Conoco has nine, Esso and Royal Dutch/Shell have six each, and Germany's Aral has four. ${ }^{158}$ Amoco is expanding into gasoline retail operations in Poland. ${ }^{159}$ The company opened its first stations in Poland this year, with plans to build 150 of them over the next decade. Texaco is about to start its own gasoline station building program and Sweden's OK Petroleum bought a controlling interest in Va-Po SA, which owns 22 gasoline stations.

\section{Romania}

The Romanian oil and gas industry is eastern Europe's largest oil and gas producer. It also has the region's largest petrochemical industry. ${ }^{160}$ With 1.6 billion barrels of proved oil reserves, more than four times the total of other eastern European countries combined, it has the most to gain from energy foreign investment. However, along with Bulgaria, its reform is one of the slowest in eastern Europe.

Romania's oil and gas industry was restructured twice, in 1990 and in $1993 .{ }^{161}$ It now consists of a series of stateowned units. These include: Rompetrol (responsible for oil and gas imports, and licensing foreign companies), Petrom (oil exploration and production), Conpet (oil distribution), Peco (gasoline distribution and sales), and Rafirom (refining). Romgas is the nation's gas distribution company. There is a possibility that further restructuring will take place, creating a single, vertically-integrated company in which up to 49 percent of the equity could be sold.

\footnotetext{
${ }^{155}$ Janowski, T. "Feature-Poland Sees No Big Change in Privatization Course," The Reuter European Business Report (February 26, 1996).

156"IEA/Hungary/Poland: Reports Praise Progress in Energy Liberalisation," Europe Energy (July 14, 1995).

157" Chevron Deal in Poland," The New York Times (June 14, 1995), p. 20.

158"Amoco to Retail Petrol in Poland," Financial Times (June 14, 1995), p. 32.

159"Amoco to Retail Petrol in Poland," Financial Times (June 14, 1995), p. 32.

${ }^{160}$ "Eastern Europe-Reluctant to Sell," Petroleum Economist, Vol. 62, No. 9 (September 1995), p. 22 ff.

${ }^{161}$ "Eastern Europe-Reluctant to Sell," Petroleum Economist, Vol, 62, No. 9 (September 1995), p. 24.
} 
After a decade of declining crude oil production (attributed both to neglect and to the use of outdated technology), production between 1994 and 1995 began to level off. ${ }^{162}$ Currently, the country produces about half its oil requirements and consumption is rising rapidly. Romania needs to invest in further exploration and has therefore attempted to encourage foreign investment.

Even though privatization legislation was passed in 1991, the lack of progress in restructuring and privatizing has thus far been discouraging to foreign capital. However, even with later modifications, the law still lacks clear guidelines for negotiating leases and does not allow disputes to be settled by international arbitration. Due to these uncertainties, Amoco, which has an onshore concession, has threatened to pull out of its proposed $\$ 60$ million investment to build a network of 60 filling stations. ${ }^{163}$ Most foreign investment in the energy sector is performed through joint ventures.

In 1992, Romania held its first licensing auction since the end of Communism, offering both onshore and offshore concessions. Shell and Amoco each were awarded an onshore block and an Enterprise Oil-Canadian Occidental consortium was awarded two offshore blocks. ${ }^{164}$ Romania's National Agency for Mineral Resources (NAMR), a newly formed agency created in 1995, is currently holding its first, and the country's second, licensing auction that includes 15 new blocks, all onshore, except one that includes an offshore block in the Black Sea continental shelf.

Romania's refining industry is inefficient and suffers from overcapacity. The use of outdated technology raises the price of the end product to over twice that of imported refined products. Romania is seeking foreign investment to help finance a \$230-million planned investment program to upgrade its five largest refineries (which account for nearly 85 percent of the country's total capacity) to western standards by $1999 .{ }^{165}$ The other five refineries will be devoted to petrochemicals. Many problems have delayed the project, and western companies, including Amoco and Texaco, are reevaluating prior commitments. ${ }^{166}$
In marketing, Royal Dutch/Shell was the first western firm to open and operate retail gasoline stations in Romania. ${ }^{167}$ Other western companies, such as Amoco, are considering retail investment options. ${ }^{168}$

\section{China and Vietnam}

China and Vietnam are largely agrarian societies ruled by Communist parties. To rebuild their economies and maintain their monopoly power, the ruling parties have allowed fragments of a market economy to develop in a move towards socialist market economies. These reforms include opening up areas to foreign participation previously inaccessible. Privatization in these areas has been restricted mainly to production-sharing agreements (PSAs) and joint ventures.

Unlike the countries of the FSU and Eastern Europe, both China and Vietnam in the past decade have experienced tremendous growth, which has increased the demand for energy supplies. In recent years, both countries have maintained a positive trend in the production of energy resources. However, China's energy sector recently has had trouble keeping up with its rapidly expanding economy, which is outstripping its energy supplies and raising its dependence on imported oil. Vietnam's emerging energy industry, on the other hand, is developing as a potential major net exporter of petroleum products and gas in the Asian-Pacific market.

\section{China}

China's petroleum industry is still under strong central control. Little has been done to allow foreign ownership of China's assets in its oil and gas industry. The industry is dominated by four large state-owned corporations: two state petroleum companies and two downstream companies. ${ }^{169}$ The largest of the two petroleum companies is the Chinese National Petroleum Corporation (CNPC), an integrated industrial organization founded in 1949 to plan, organize, and manage the exploration and develop-

\footnotetext{
162"Romania Pinpoints Blocks on Offer," Oil \& Gas Joumal (May 13, 1996), p. 42.

163."Eastern Europe-Reluctant to Sell," Petroleum Economist, Vol. 62, No. 9 (September 1995), p. 23. "Czech Refinery Deal, Long in Making, Finally Signed," Platt's Oilgram News, Vol. 73, No. 221 (November 16, 1995), p. 6.

IG+"Romania Invites Tenders for Oil and Gas Exploration," Financial Times (April 24, 1996), p. 37.

165"Eastern Europe-Reluctant to Sell," Petroleum Economist (September 1995), p. 24.

166"U.S. Companies Poised for Crack at Romanian Privatization Drive," The Oil Daily, Vol. 45, No.62 (March 31, 1995 ), p. 1.

167"U.S. Companies Poised for Crack at Romanian Privatization Drive," The Oil Daily, Vol. 45, No.62 (March 31, 1995 ), p. 1.

${ }^{168 " W e s t e r n ~ F i r m s ~ P i c k ~ u p ~ P a c e ~ o n ~ R e t a i l ~ G r o w t h ~ i n ~ E a s t e r n ~ E u r o p e, " ~ T h e ~ O i l ~ D a i l y, ~ V o l . ~ 45, ~ N o .143 ~(J u l y ~ 28, ~ 1995), ~ p . ~} 2$.

${ }^{169}$ Energy Information Administration, Country Energy Profile, China (Washington, DC, February 1995), p. 17.
} 
ment of onshore oil and natural gas resources. The CNPC controls more than 95 percent of China's onshore oil and natural gas fields. All offshore oil and gas exploration andproduction is under the control of the second petroleum company, the China National Offshore Oil and Gas Corporation (CNOOC). It was founded in 1982 to act as the state representative in joint developments with foreign companies of China's offshore oil and gas reserves. The China National Petrochemical Corporation (Sinopec), the state refiner, was formed in 1983 to develop an integrated Chinese refining and petrochemical system. The China National Chemical Import and Export Corporation (Sinochem) is the import and export company responsible for trading international crude oil and oil products. It is the country's main importer of crude oil.

In 1993, China became a net oil importer for the first time. China's strategy is to increase domestic oil and gas output by stabilizing production in eastern China's mature fields, by increasing the focus on exploration and development in the western regions and by continuing to encourage offshore development. Central to this strategy is an expansion of exploration and production joint ventures with foreign companies.

Thus far, China has adopted a very limited form of privatization. Most foreign activity is in productionsharing contracts. Most oil and gas production comes from onshore activity; however, until recently, most foreign activity had been limited to offshore exploration and development. In 1993, the need to meet production targets led China to open up onshore areas to foreign investors with the first of three investment auctions.

Eastern China, the country's traditional producing region, is where most of the country's large oil and gas fields are located. Oil production from eastern fields accounts for more than 90 percent of the country's total crude oil production of 3 million barrels per day, ${ }^{170}$. but these aging fields are beginning to decline.

China has recently emphasized exploration and development expenditures in western regions, particularly in the Xinjiang region of the northwest. Most onshore tracts offered to foreign investors in the three investment auctions are located in this area. Crude oil production in 1994 from the Xinjiang region in northwest China was 225,000 barrels per day. ${ }^{171}$ The three major basins in the Xinjiang region are Tarim, Turpan-Hami, and Junggar. Experts believe Tarim is the most promising as far as the possibility of finding "elephant-class" discoveries. However, Tarim's remoteness and lack of infrastructure have made it difficult for transportation facilities to keep up with discoveries, temporarily reducing production. To entice foreign companies who are concerned about getting their oil to market, China has launched a massive infrastructure expansion program in this region which will include pipelines, a trans-desert highway, parallel rail lines, and expanded storage.

Offshore crude oil production in 1994 averaged 130,000 barrels per day, ${ }^{172} 4.5$ percent of China's total crude oil production. Until recently, all foreign activity was limited to offshore exploration and development. Offshore China was opened to foreign investors in 1982. Since then, the CNOOC has held four investment auctions. By 1994, foreign investment in China's offshore oil and gas exceeded $\$ 4$ billion. Currently, there are 12 offshore oil and gas fields in operation, of which four include participation with foreign partners - ACT Operating Group of Agip SpA, Amoco and partners, Chevron, Japan's JHN Group, Phillips Petroleum, and Texaco. ${ }^{173}$

Natural gas makes up only about two percent of China's domestic energy production and has long been overshadowed by the country's coal and oil production. However, environmental concerns have led China to recently shift its oil and gas exploration and development emphasis towards natural gas, both on- and offshore. The CNPC plans to step up gas exploration and development in western China. Gas production is expected to increase offshore since China's largest offshore gas field, Yacheng $13-1,{ }^{174}$ began producing in early 1996 . In addition, the Sichuan gas project has been proposed to develop and rehabilitate fields in the Sichuan province, where most of China's gas is produced, in order to halt the decline in field productivity. ${ }^{175}$

By the end of 1994, China's total refining capacity had reached 3.4 million barrels per day, making it the fourth

\footnotetext{
${ }^{170} 1995$ production: Energy Information Administration, International Petroleum Statistics Report,(Washington, DC, June 1996), p. 5.

171"China's Upstream Programs Advance Onshore and Offshore," Oil and Gas Journal (September 25, 1995) p. 32.

172"China's Upstream Programs Advance Onshore and Offshore," Oil and Gas Journal (September 25, 1995), p. 31.

173"China's Upstream Programs Advance Onshore and Offshore," Oil and Gas Journal (September 25, 1995), p. 31.

${ }^{174} \mathrm{CNOOC}$, ARCO and Kuwait's Santa Fe Co. are jointly developing the field.

${ }^{175}$ Energy Information Administration, Country Analysis Briefs: 1995 (January 1996).
} 
largest refiner in the world, after the United States, the FSU; and Japan. ${ }^{176}$ The country's refining capacity is rising, but not fast enough to accommodate China's soaring domestic demand for refined products. Thus, China has embarked on a major restructuring and expansion plan and started to encourage foreign joint venture participation. The focus is to modernize the industry to international standards and to add an additional refining capacity of about 1.4 million barrels per day by year $2000 .{ }^{177}$ Beginning in the early 1990s, Sinopec led efforts to expand capacity and build new "grassroots" refineries by decentralizing the refining industry. It began to allow other Chinese oil companies, such as the CNPC, 'to build refineries. However, government restrictions limiting market access have made it difficult for potential foreign investors to finalize projects. For example, France's Elf Aquitaine pulled out of a proposed \$2.5-billion refinery project in Shanghai at the end of 1995, while Shell has yet to reach an agreement with Chinese officials to build a refinery in the Guangdong province, after seven years of negotiations. ${ }^{178}$ As a result, although many proposals have been submitted by foreign companies, presently there are only two foreign companies with investments in China's refining industry-France's TOTAL owns a 20-percent stake in a northeastern Chinese refinery, while ARCO owns a stake of 9.9 percent in the Zhenhai Refining and Petrochemical Company. ${ }^{179}$

\section{Vietnam}

Unlike the countries of the Former Soviet Union and Eastern Europe, who are restructuring their mature oil and gas industries, Vietnam is building a nascent oil and gas industry, spurred by foreign investment. Due to this investment, Vietnam-with virtually no hydrocarbon production a few years ago-produced 171,000 barrels per day of oil in $1995 .{ }^{180}$ The country is already on its way to becoming a major source of petroleum in the Asian-Pacific energy market. Vietnam opened its economy to foreign investment in 1988. However, U.S. companies did not begin investing until 1994; when the twenty-year U.S. trade embargo was lifted.
Vietnam has tried to make the country more attractive to foreign investors by various reforms in its petroleum law. The country's first petroleum law was ratified in July 1993. This law assigns upstream and downstream petroleum operations to the state-owned enterprise, Petrovietnam, founded in 1977. It also gives the company the power to parcel acreage to select contractors based on competitive investment auctions or other governmentannounced programs. Most foreign investments are in the form of production-sharing agreements or joint ventures. Vietnam also is directing foreign investor activity toward the building of infrastructure to include refineries, gas pipelines, and hydrocarbon-fueled power plants. Unlike many former Communist economies in transition, where uncertainty is causing lengthy delays, Vietnam has established a stable legal and tax environment that reduces uncertainity and enables companies to quickly move from the initial stage of signing agreements to the stage of producing the fields.

However, regional territorial disputes are an impediment to the development of some of Vietnam's offshore petroleum resources. Hydrocarbon potential off the Spratly Islands in the South China Sea and competition for additional energy reserves recently reignited a longstanding feud between China and Vietnam surrounding ownership of the Islands and adjacent waters. The territorial dispute arose again when China awarded an exploration block in the disputed waters to the U.S. independent oil company Crestone Energy Corporation. Later, Vietnam awarded an adjacent block to a Mobil-led consortium. Six countries-China, Vietnam, Taiwan, Philippines, Brunei, and Malaysia-all lay claim to this part of the South China Sea. ${ }^{181}$

Virtually all Vietnamese exploration and production activity occurs off Vietnam's southeastern coast. By the end of 1994, after two licensing auctions and the signing of 25 offshore production-sharing agreements, the number of exploratory wells rose considerably. ${ }^{182}$ Most petroleum production in Vietnam occurs in three fields, Bach Ho, Rong, and Dai Hung. The Bach Ho and Rong fields are operated by VietSovPetro, a Vietnamese-Russian joint

\footnotetext{
${ }^{176}$ Energy Information Administration, International Energy Annual 1993, DOE/EIA-0219(93)(Washington, DC, May 1995$)$, p. 42.

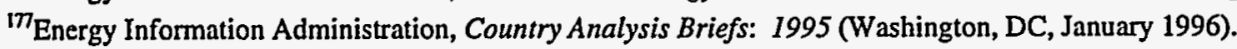

178 "Demand for Refineries is High in China," The Wall Street Journal (December 26, 1995), p. A4.

179 "Demand for Refineries is High in China," The Wall Street Journal (December 26, 1995), p. A4.

180" Worldwide Production,"Oil and Gas Journal (December 25, 1995), p. 41.

181"Chinese Bureaucrats Draw the Line in South China Sea," Petroleum Economist (July 1995), p. 16.

IB2. Offshore Gas Developments Dominate Activity; Far East's Oil and Gas Industry; 50th Annual International Outlook Industry Overview," World Oil, Vol. 216, No. 8 (August 1995), p. 128ff.
} 
venture. Bach $\mathrm{Ho}$, the country's first and largest producing oil field, was discovered in 1975 by Mobil, which abandoned the well when the U.S. withdrew from Vietnam. The well was later developed in 1986 by VietSovPetro. Both the Rong and Dai Hung fields-led by a BHP consortium composed of BHP, Petronas of Malaysia, Total, Sumitomo, and the Vietnam Oil and Gas Corporation-came on line in $1994 .{ }^{183} \mathrm{Newly}$ discovered fields could be on line soon, raising the country's production even further. For example, Petronas is developing its Ruby field, while Mitsubishi and Japan National Oil are developing the Rang Dong field, with production in both fields to start by 1997. Other fields that could come on line are the Flying Horse, discovered by Lasmo; the Red Orchid and the West Orchid (both located in disputed waters), and the Sunflower North and South Fields, discovered by BP; as well as two other unnamed fields, one discovered by Total and the other discovered by Shell/Pedco. These major fields are all located in the Nam Con Son Basin. ${ }^{184}$ Despite initial exploration successes, geological difficulties are making it hard to estimate recoverable reserves, raising concerns over the viability of some projects. Several fields that were originally thought to be quite large are now being downgraded-for example, the BHP consortium's Dai Hung field and the Mobil consortium's Thanh Long block. Further, BHP is considering abandoning its Dai Hung project if new terms cannot be negotiated. ${ }^{185}$

Several recent gas discoveries have opened up the future of the gas industry in Vietnam. Perhaps the most significant activity involves two major gas field strikes in southern Vietnam drilled by British Petroleum (BP) and its partners, India's ONGC, and Norway's Statoil, with reserves estimated at a combined 2 trillion cubic feet. ${ }^{186}$
Another area of discovery with potential gas reserves is at the Hai Thach gas field. It may take a few years before reserve estimates can be formulated, but if the country's proven natural gas reserves are estimated between 12-35 trillion cubic feet, Vietnam plans to commit itself to the development of a natural gas industry for domestic use as well as possible export markets. ${ }^{187}$. In April 1995, Vietnam commissioned a consortium comprised of BP, British Gas, Mobil, and Mott Ewbank Preece to develop a master national gas plan. ${ }^{188}$ In the meantime, Vietnam's first gas pipeline (built by Hyundai of Korea) went into operation in 1995, bringing production ashore from the Bach Ho field. ${ }^{189}$ Vietnam also is studying the possibility of exporting gas via pipeline to Thailand. ${ }^{190}$

Substantial upstream activity has led to Vietnam's generating plans for downstream oil and gas infrastructure projects. As Vietnam's economy grows, it plans to reduce its reliance on imports by building its first oil refinery by the year 2000. Vietnam commissioned two feasibility studies regarding the possible construction of a 130,000 barrels-per-day refinery. France's TOTAL, a consortium member of the study, withdrew from the project over objections concerning the chosen site, located in a remote area of central Vietnam. South Korea's LG Group, Petronas of Malaysia, and Conoco were chosen to replace TOTAL, but the companies said that no decision has been made beyond a feasibility study since there are doubts about the viability of the project. ${ }^{191}$ Vietnam hopes to build a second 100,000 - barrels-per-day refinery after the first plant comes on line. ${ }^{192}$ In the meantime, Petrovietnam has asked for bids to begin studies for a second refinery, likely to be located in the northern part of the country. Despite foreign involvement in upstream activities, Vietnam has denied foreign investors access to its retail sector. ${ }^{193}$

\footnotetext{
183"Petro Vietnam's Ho Si Thoang Outlines Successes, Predicts Future Gas Industry," Offshore (November 1995), p. 39.

184"PetroVietnam's Ho Si Thoang outlines successes, Predicts Future Gaslindustry," Offshore (November 1995), p. 39.

185"BHP Demand for Better Oil Field Terms is Rejected,"Financial Times (May 10, 1996), p. P6.

${ }^{186 " V i e t n a m ~ S e t ~ t o ~ L a u n c h ~ G a s ~ I n d u s t r y, ~ E x p o r t s, " ~ T h e ~ R e u t e r ~ E u r o p e a n ~ B u s i n e s s ~ R e p o r t ~(M a r c h ~ 12, ~ 1995) . ~}$

${ }^{187}$ Energy Information Administration, Country Analysis Briefs: 1995 (Washington, DC, January 1990).

${ }^{188}$ "PetroVietnam's Ho Si Thoang Outlines Successes, Predicts Future Gas Industry," Offshore (November 1995), p. 39. Energy Information Administration, Country Analysis Briefs: 1995 (Washington, DC, January 1995).

${ }^{189}$ "PetroVietnam's Ho Si Thoang Outlines Successes, Predicts Future Gas Industry," Offshore (November 1995), p. 39.

190"Discoveries, Production Add Luster to Offshore Vietnam's Outlook," Oil and Gas Journal (July 17, 1995), p. 17.

191" Vietnam Names New Refinery Partners," Financial Times (January 11, 1996), p. P5.

${ }^{192}$ Energy Information Administration, Country Analysis Briefs: 1995 (Washington, DC, January 1996).

${ }^{193}$ "Vietnam struggles to refine policy on fuel," Financial Times (March 26, 1996), p. P5.
} 


\section{Privatization and the Genesis of the Multinational Power Company}

\section{Underlying Factors and Regional Trends}

\section{Financial Developments in Global Power}

Electric power is expected to be the fastest-growing source of end-use energy supply throughout the world over the next two decades. To meet global power projections, it is estimated that over $\$ 1$ trillion will have to be spent during the next 10 years. ${ }^{194}$ The electric power industry has undergone a substantial degree of privatization in a number of countries over the past few years. Power generation growth is expected to be particularly strong in the rapidly growing economies of Asia, with China leading the way (Table3). The reasons for electric utility privatization are numerous and vary from country to country. Some of the more evident reasons include the following:

- Raising revenues for the state through asset sales

- Acquiring investment capital

- Improving managerial performance

- Moving toward market-determined prices

- Technology transfer

- Reducing the frequency of power shortages

- Reducing the cost of electricity to consumers through efficiency gain

- Taking advantage of creating national and regional power grids, and

- Re-thinking whether electric power generation in today's economy constitutes a natural monopoly.
Electricity demand is expected to grow fastest in the developing nations, particularly those with rapidly growing populations and economies. For developing nations, privatization is one means of obtaining badly needed foreign capital. It is also a means of transferring western technology to second and third world countries.

Privatization of formerly state-owned electric power assets has opened up enormous investment opportunities. For foreign investors, investment in overseas electricity assets offers opportunities to achieve potentially higher returns and, in many cases, to realize greater growth opportunities than are available at home.

The financing of power projects around the world has changed in recent years. Non-private sources of investment funds have grown increasingly scarce, and the critical role such publicly-financed institutions, such as the World Bank, have played in financing electrical projects has diminished significantly. However, several new entrants in financing of overseas electric power investment have recently emerged-particularly in the area of equity finance. Some of these new sources of capital include the world's major petroleum companies, natural gas pipeline companies, electric utilities, and also some of the world's major construction and power equipment manufacturing companies. Construction companies are increasingly setting up project financing departments and committing their own capital to financing power projects. ${ }^{195}$ Investors based in the United States have been the leading source of capital for many of these projects. Some U.S. mutual funds have been started for the exclusive purpose of investing in Latin American power production. The growth trend in U.S. direct investment in foreign electric utilities (and similar services) has clearly been upward in contrast to U.S. direct investment abroad in petroleum. ${ }^{196}$

\footnotetext{
194"Cross-border Utility Investments: Translating Investment Risk into Global Advantage," Electricity Journal (June 1995), pp. 31-37.

195"Project Equity Can be the Ultimate Deal," Engineering News-Record, Vol. 236, No. 14 (April 8, 1996), p. $24 \mathrm{ff}$.

${ }^{196}$ U.S. Department of Commerce, Bureau of Economic Analysis, Survey of Current Business (Washington, DC, August 1996 ), Table 18.
} 
Table 3. New Power Plant Capacity Required Outside North America by 2000 (Gigawatts)

\begin{tabular}{|c|c|}
\hline Africa & 25 \\
\hline Brazil & 30 \\
\hline China $\ldots \ldots \ldots \ldots \ldots \ldots \ldots \ldots \ldots$ & 100 \\
\hline Eastern Europe $\ldots \ldots \ldots \ldots \ldots \ldots$ & 15 \\
\hline FSU $\ldots \ldots \ldots \ldots \ldots \ldots \ldots \ldots \ldots \ldots \ldots$ & 29 \\
\hline India $\ldots \ldots \ldots \ldots \ldots \ldots \ldots \ldots \ldots$ & 55 \\
\hline Japan..$\ldots \ldots \ldots \ldots \ldots \ldots \ldots \ldots$ & 50 \\
\hline Middle East $\ldots \ldots \ldots \ldots \ldots \ldots$ & 50 \\
\hline Other Asia $\ldots \ldots \ldots \ldots \ldots \ldots \ldots$ & 50 \\
\hline Other Latin America $\ldots \ldots \ldots \ldots \ldots$ & 42 \\
\hline Western Europe..$\ldots \ldots \ldots \ldots \ldots$ & 99 \\
\hline World Total $\ldots \ldots \ldots \ldots \ldots \ldots \ldots$ & 545 \\
\hline
\end{tabular}

Source: Salomon Brothers.

There are a number of ways to privatize electric power. One involves the sale of state-owned electric power assets. Another involves allowing less restricted or unrestricted investment in new power assets-the independent power project. Arrangements whereby a foreign company builds a power unit and operates the unit for an agreed-upon number of years before transferring ownership to the host country has been another important vehicle for financing electric power. This latter investment arrangement is commonly referred to as a build, operate, transfer agreement, or BOT. In several nations, rate reform has also played a critical role in encouraging such non-utility electric power investments.

In several cases discussed later in this chapter, privatization has involved foreign utilities purchasing one or more utilities in other countries. Some privatization efforts have involved consortiums of foreign and domestic companies. Joint ventures with host nation companies have been another avenue of privatization. In other cases, foreign companies or investors have purchased shares in newly-privatized electric utilities. In a few cases, recentlyprivatized companies have acquired ownership interests in other recently-privatized companies.

\section{The Convergence of Electricity and Natural Gas}

Privatization has also resulted in a growing convergence of petroleum-related activities and electric power-related activities. The growing interconnection between petroleum companies (particularly those with substantial natural gas production and/or distribution activities) and electric power generation stems from a number of developments. In certain regions, natural gas is becoming the fuel of choice for new electricity generation projects, in part, because of the relative environmental advantage that natural gas has over coal or oil. The much improved efficiency of gas-fired electricity generation units over the last several years has also improved natural gas's relative competitiveness as a fuel for the generation of electricity. Furthermore, in several countries natural gas deregulation has accompanied the deregulation of electric power. In the aftermath of several prominent deregulatory efforts in the U.S. natural gas market--culminating in the Federal Energy Regulatory Commission's (FERC's) final deregulatory push in 1993, through the FERC Omnibus Order 636--U.S. natural gas pipeline companies have become particularly well-suited to enter newly-opened markets in a variety of international regions undergoing a deregulatory and transitional phase. The sections that follow review developments in power generation, transmission, and distribution privatizations as they have occurred across international regions.

\section{Regional Developments}

The privatization of electric utilities has occurred and is continuing to occur in both developing and developed countries. Although varying extensively in degree and method, countries as different as India and the United States have exposed their electric power generation industries to greater market forces. Chile has led the way with electric utility privatization in the late 1980's, followed by the United Kingdom. Currently, most Latin American countries are privatizing their electric power industries to some extent. Prominent electric power privatization efforts also are currently underway in Australia, Canada, China, Scandinavian countries, India, Indonesia, Morocco, Pakistan, the Philippines, and Eastern Europe. A brief discussion of the different regions is appropriate to highlight their differences and similarities in electricity privatization.

Some countries in OECD Europe have taken steps to introduce elements of competition in their power industries. Others are in the process of formulating regulatory changes that will ensure a move toward privatization and an overall restructuring of their electricity markets. Currently, the European Union energy ministers are working on plans to create an internal electricity market, but progress has been slow due to resistance from some state-owned electricity monopolies. OECD European nations currently undergoing major privatization efforts include the United Kingdom, Finland, Norway, Sweden, and Portugal. These efforts vary considerably across 
countries and are for the most part still in a transitional phase. ${ }^{197}$

Similarly, the shape of the electric power industry is changing in Canada. In some jurisdictions, consideration is being given to unbundling electricity supply to its three principal functions--generation, transmission, and distribution. Privatization of North America's largest power utility, Hydro Ontario, is also being considered, excluding its nuclear generating plants.

Of all world regions, Asia is expected to show the most rapid increase in economic growth and electricity consumption over the next few decades. This region is also expected to lead the way in the level of independent power producers activity. While non-OECD Asia accounted for only 14 percent of total world electricity consumption in 1992, it is expected to account for nearly one-third of total demand growth between now and 2010. China, India, and Australia are, respectively, Asia and Oceania's largest economies, as well as the next largest consumers of electricity after Japan (an OECD country). They also account for some of the largest foreign investments in electricity generation overseas. All three nations have undergone significant attempts at electricity privatization. Some of the relatively smaller economies such as Indonesia, New Zealand, Pakistan, and the Phillippines, have also undergone significant privatization efforts.

Africa, too, is undergoing changes in its electricity industry structure. Morocco is undertaking the privatization of its electricity industry, much as the smaller countries of Asia and Oceania.

Privatization efforts are generally sweeping Latin America and the electricity industry is no exception. Many Latin America nations have undertaken economic and political reforms of historic dimensions in recent years. Democratic government and free market economics have been central to these reforms. Both have done much to restore Latin America's creditworthiness.
There are several reasons for the current wave of electricity privatization in Latin America. Poor economic performance during the 1980s left many Latin American countries with deteriorating electricity infrastructures and no increase in generation capacity despite rapid population growth.

Latin America's growing economies and growing populations are expected to continue to stimulate expansions in electricity generation capacity well into the future. In the first half of the 1990's, most Latin American countries experienced increased economic growth rates. Long-term economic growth prospects also improved. Future economic growth is very dependent on Latin America's expanding its powergenerating capacity. Expansion of access to electricity is also important as currently 30 percent of the population of Central and South America have no access to the power grid. ${ }^{198}$ Forecasts of electricity demand predict a 2.6-percent annual growth in Latin America well into the next century. ${ }^{199}$

Latin America has many primary resources that can be used to generate electricity, including water for hydroelectric generation, and coal, natural gas, and oil for steam-fired generation. Historically, hydroelectric generation has been the primary method of generating electricity in Latin America. ${ }^{200}$ However, new power generation projects seem to indicate a movement to natural gas and coal. As of 1994, 30 percent of electricity generation in all of Latin America was fueled by natural gas. ${ }^{201}$ Concurrent and related to the movement to natural gas-fired electricity generation has been increased investment in natural gas pipelines (see the box "Latin America's Emerging Regional Natural Gas Pipeline Network").

Electricity privatization is different, depending on the particular country on which one focuses. However, some countries are more similar than others. While some countries have sought aggressive privatization and reform of their electric power sectors, others have been

\footnotetext{
${ }^{197}$ Much of the details concerning the methods and progress of privatization for the countries discussed in this report, along with forecasts of regional electricity demand growth, came from: Energy Information Administration, International Energy Outlook 1995 (DOE/EIA-0484(95)) (Washington, DC, June 1995), pp. 73-87.

${ }^{198}$ Energy Information Administration, International Energy Outlook 1995 (DOE/EIA-0484(95)) (Washington, DC, May 1995$)$, p. 74.

${ }^{199}$ Energy Information Administration, International Energy Outlook 1996 (DOE/EIA-0484(96)) (Washington, DC, May 1996 ), p. 85.

${ }^{200}$ Energy Information Administration, International Energy Annual 1993 (DOE/EIA-0219(93)) (Washington, DC, May 1995), Tables 2.6, 2.7, 2,8 , and 6,1 .

${ }^{201}$ Slaughter, Andrew, "Power Generation Key to Global Natural Gas Market," Electrical World (November 1994), p. 61.
} 


\section{Latin America's Emerging Regional Natural Gas Pipeline Network}

One serious problem currently facing Latin American countries is their antiquated energy infrastructure, particularly that for natural gas transportation. This problem could grow even more acute as Latin American natural gas consumption has been predicted to grow as much as four to five percent annually through 2005, a substantially larger growth rate than the two-percent forecast for worldwide annual growth. ${ }^{a}$ Much of this growth will come from electricity generation expansions. Concurrently, heightened environmental concerns strengthen natural gas demand for both power generation and other uses. The two primary Latin American destinations for natural gas shipments, Brazil and Chile, have substantial air pollution problems.

To address these difficulties, natural gas pipeline projects costing nearly $\$ 7$ billion are either under construction or under active consideration. These proposed transportation pipeline construction projects will add more than 6,000 miles of new natural gas pipeline and will connect natural gas-producing areas in Argentina, Bolivia, Colombia, and Peru with consumers in Brazil and Chile, and seaports for export markets. Other projects also under consideration will connect Argentina with Paraguay and Uruguay.

These projects offer substantial opportunities for foreign companies. Several international companies are involved in these projects; two of which are U.S. companies--Enron and Tenneco. Both companies are engaged in several Latin American pipeline and associated electricity generation projects. Perhaps the most significant is the construction of the largest pipeline project in Latin America, the $\$ 1.5$-billion, 2,050-mile Bolivia/Brazil pipeline. ${ }^{b}$ Enron will have a 34-percent share in the Bolivian segment and an 8-percent share in the Brazilian segment. ${ }^{c}$ Tenneco Gas is one of the principals in the Brazilian segment of the Bolivia/Brazil pipeline and in a \$700-million, 750-mile Argentina/Chile pipeline. Tenneco holds a 25-percent share in each of these projects. ${ }^{d}$

The recent proliferation of regional trade accords has done much to lay the legal and commercial foundations necessary for these natural gas transportation projects to get underway. These trade associations generally involve neighboring countries: the Andes Group (Grupo Andino), the Southern Cone Common Market (Mercosur), and the Group of Three Amigos. ${ }^{e}$ It is likely that the development of these trade associations and the rise in their significance resulted in sufficient cooperation to undertake such a monumental set of construction projects. Further, as the natural gas pipelines become a reality, the pipelines will be tangible evidence of the benefits of cooperation between Latin American countries. Thus, the cooperation that led to the pipeline projects may be strengthened further by the pipeline projects.

'Energy Information Administration, International Energy Outlook 1996 (DOE/EIA-0484(96)) (Washington, DC, June 1996$)$, p. 9.

b"Bolivia-Brazil Gas Pipeline About to Take Off: Seen As Litmus Test for Southern Cone Gas Grid," Oil and Gas Journal (August 7, 1995$),$ p. 39.

'Enron Corp, 1994 Annual Report to Shareholders and Customers, p. 26.

d Tenneco, Tenneco 1994 Annual Report to Shareholders, p. 36.

The Andes Group includes Bolivia, Colombia, Ecuador, Peru, and Venezuela. Mercosur includes Argentina, Brazil, Paraguay, and Uruguay. The Big Three includes Colombia, Mexico, and Venezuela. See "Focus on the Grupo Andino," Latin America Regional Reports (April 20, 1995), p. 4 .

slow to reform. Thus, a review of electricity privatization efforts on a nation-by-nation basis is provided to demonstrate the differences and similarities between countries.

\section{The United Kingdom}

Among developed economies, 'the United' Kingdom's electric utility industry privatization efforts have been the first, largest, and most ambitious thus far. The United Kingdom began to privatize its power industry in 1990 and completed the final phase of privatization in July of 1996.202 Privatization of electricity in Great Britain has occurred in the context of a wholesale privatization of several other state-owned industries. The 1980's saw awave of privatization by the United Kingdom, beginning in 1981, when British Aerospace was auctioned off, followed by British Telecommunications in 1984. Soon

\footnotetext{
202"The Price Report; UK Electricity Industry," Petroleum Times (May 5, 1995), p. 1.
} 
afterwards, there were privatizations of British Gas (1986) (see the box entitled "Natural Gas Privatization in the United Kingdom"), British Airways (1987), British Steel (1988), and Britain's water utilities (1989). More recently, British Coal was privatized in 1995, and British Rail in 1996. The sale of the Post Office is also being considered. Also, in a series of transactions starting in 1979, the British government began to sell off its ownership in British Petroleum, culminating in the government's sale of its remaining 2-percent share in 1995 (see Chapter 2 for a discussion on the privatization of British Petroleum). Through all of 1995, the UK had raised over $\$ 95$ billion through privatization. ${ }^{203}$

Prior to privatization, in England and Wales, the nationalized Central Electricity Generating Board (CEGB) owned all power stations and transmission grids. On the national level, the initial steps toward privatization involved the restructuring of the CEGB into four separate companies, still owned by the British government. Later, the two power generation companies, PowerGen and National Power, both issued equity shares in 1990. National Power is the larger of the two companies and accounts for nearly a quarter of UK electricity generating capacity. ${ }^{204}$ The national electric transmission grid is managed by the National Grid Company which was initially owned by twelve regional electricity distribution companies but became an independent company in 1995. The 12 regional companies are: East Midlands Electricity, Eastern Group, London Electricity, Manweb, Midlands Electricity, Northern Electric, Norweb, Seeboard, Southern Electric, South Wales Electric, South Western Electricity, and Yorkshire Electricity. The fourth company, Nuclear Electric, (which consists of eight nuclear-fired electricity generating plants) was privatized in July 1996 as the company British Energy. ${ }^{205}$ It should be noted that privatization did not mean complete deregulation and in the aftermath of privatization retail rates were still regulated and wholesale rates frozen.

In Scotland, privatization involved the creation of two integrated companies, Scottish Hydro-Electric and Scottish Power (a distribution and generation company for Scotland), and in Northern Ireland, Northern Ireland Electricity was formed.

Soon after privatization, the structure of Britain's electric industry began to change dramatically, particularly at the distribution stage. Through a series of mergers and acquisitions, the twelve regional electricity distribution companies, as a group, became more vertically integrated. Both National Power and PowerGen (the two newlycreated generation companies) placed bids on distribution companies. Foreign electricity companies, particularly from the United States, also placed bids on both the power and distribution companies.

Since going public, several of the 12 regional distribution companies and one power company have been takeover targets (Table 4). The largest foreign acquisition of a UK electric utility thus far has been the purchase of Midlands Electricity (one of the regional distribution companies) by the U.S. companies General Public Utilities and Cinergy for $\$ 2.6$ billion. The next largest involved the purchase of another regional electricity distribution company (Seeboard) for $\$ 2.5$ billion by Central and South West of Dallas, Texas. Southern Company, of Atlanta, Georgia (the second largest utility in the United States), purchased South Western Electricity, another regional electricity distribution company, for $\$ 1.7$ billion. Meanwhile, Prudential took a 4.9-percent equity stake in Yorkshire Electricity, yet another regional distribution company.

There has also been some internal consolidation of Great Britain's electric power and distribution industries and integration with the UK's recently-privatized water utilities. Both Norweb and South Wales Electricity were acquired/merged with local water power utilities, while Scottish Power acquired Manweb. North West Water, which purchased Norweb, outbid the U.S. utilities Houston Industries and Central and South West Corp. In addition, Southern Electric outbid Scottish Power to acquire Southern Water PLC for $\$ 2.4$ billion. ${ }^{206}$ The UK's Southern Electric is the second largest electricity distribution company in England and Wales. With its acquisition of Southern Water and its recently-obtained license to become a natural gas distributor, it could become the first full service regional utility. ${ }^{207}$

In early 1996, there were several attempted acquisitions which were in the end rejected by the British government. Among recent takeover targets, those involving Britain's electrical power generation assets have been among the most controversial. National Power PLC had attempted a takeover of Southern Electric PLC, the second largest

\footnotetext{
${ }^{203}$ "Sale of the Century," The Wall Street Journal (October 2, 1995), p. R17.

${ }^{204}$ Ironically at the same time, two consortia led by National Power and Southern Company competed for power projects in Pakistan. Although National Power won the bid, if Southern Co. succeeds in its merger attempt, essentially Southern wins in Pakistan as well.

205 "Britain to Privatize Nuclear Power Company," The New York Times (May 29, 1996), p. D4.

206 "Southern Water of Britain Accepts Offer from 2d bidder," The New York Times (May 30, 1996), p. D5.

207"Southern Water of Britain Accepts Offer from $2 d$ bidder,"The New York Times (May 30, 1996), p. D5.
} 
Table 4. The Structure of the Electricity Market in the United Kingdom and

Recent Privatization-Related Transactions

(Million Dollars)

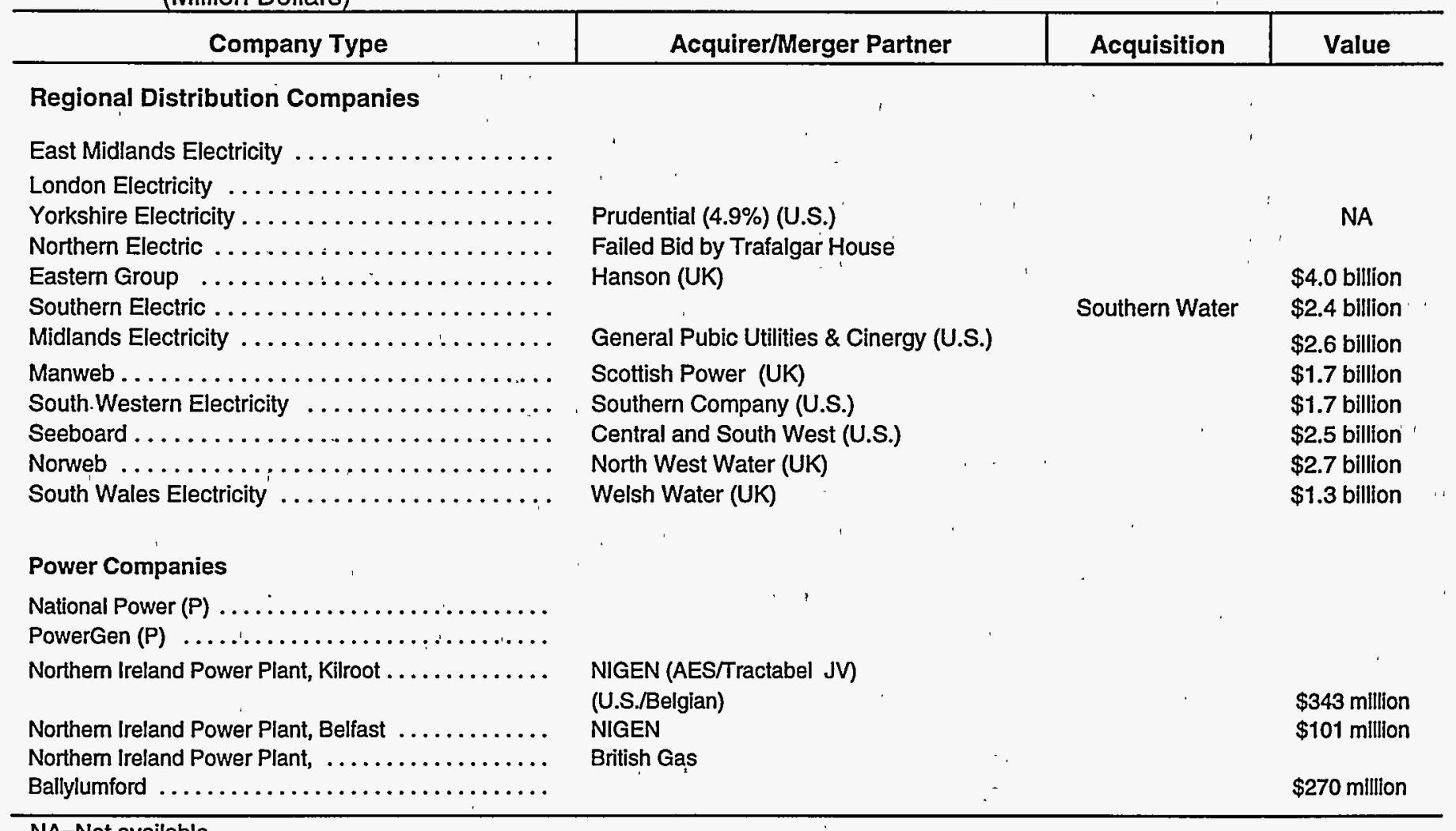

NA=Not available.

Sourceș: European Power, McGraw-Hill's Independent Power Report, Financial Times, various issues.

regional distribution company in the United Kingdom, for $\$ 4: 4$ billion..$^{208}$ In turn, National Power was a takeover target of the U.S.-based Southern Company, which had just earlier purchased South Western Electricity. PowerGen, the other major generation company, had mounted a takeover attempt of Midlands Electricity. However, the British government blocked the proposed merger of Southern Electric and National Power, and the purchase of Midlands Electricity by PowerGen because of concerns about maintaining competitive markets. Had the Southern Company/National Power merger and the National Power/Southern Electric acquisition gone through, Southern Company would have owned two of the twelve regional distribution companies (with neighboring territories) along with the largest generation company. ${ }^{209}$ A U.S. company would then have become both the largest power generation company and the largest power distribution company in the United Kingdom.
Meanwhile, Hanson Corporation's electric distribution subsidiary, Eastern Group, has purchased power plants from both National Power and PowerGen, making the Eastern Group an integrated electricity company. (Hanson Corporation is a UK-based conglomerate with interests in U.S. and Australian coal mining.) The Eastern Group is the largest regional distribution company in the UK and accounts for roughly 10 percent of the national electricity distribution market.

\section{Independent Power Producers}

There have also been several independent power investments in England and Wales in recent years involving both U.S. and other foreign investors (Table 5). These include an investment by Enron in 1991 in the 1,875megawatt (MW) Teesside power facility, the largest gasfired plant in the world. ${ }^{210}$ Other independent electric power generation investments include: an investment by

\footnotetext{
${ }^{200}$ "The Busiest Merger Lab: The UK Electricity Sector," Electrical World (July 1996), p. 29.

209 "Power Play Gets Rough," The Daily Telegraph (April 20, 1996), p. 2.

${ }^{210}$ Enron Corp 1995, Annual Report to Shareholders and Customers, p. 1.
} 
Table 5. Major Foreign Equity Investments in UK Independent Power Projects

\begin{tabular}{|c|c|c|c|c|c|}
\hline Project Site & MW & $\begin{array}{l}\text { Total Project Cost } \\
\text { (million dollars) }\end{array}$ & $\begin{array}{l}\text { Equity } \\
\text { Share }\end{array}$ & $\begin{array}{l}\text { Year of } \\
\text { Completion }\end{array}$ & $\begin{array}{c}\text { Company/Companies } \\
\text { Involved }\end{array}$ \\
\hline Teesside .. & 1,875 & 1,440 & 50 & 1991 & Enron \\
\hline Medway ........... & 660 & 650 & $\begin{array}{l}38 \\
38\end{array}$ & 1992 & $\begin{array}{l}\text { Seeboard }^{a} \\
\text { AES }\end{array}$ \\
\hline Brigg South ........ & 240 & 221 & 25 & 1992 & IVO (Finland) \\
\hline Derwent ........... & 214 & 240 & 33 & 1992 & Mission Energy \\
\hline Humber Power...... & 750 & 780 & $\begin{array}{l}30 \\
25 \\
20\end{array}$ & 1994 & $\begin{array}{l}\text { IVO } \\
\text { Tomen } \\
\text { ABB }\end{array}$ \\
\hline
\end{tabular}

${ }^{2}$ Seeboard is a subsidiary of the U.S. utility Central and South West Corp.

$M W=$ Megawatts.

Source: Cambridge Energy Research Associates Central and South West (Seeboard's parent company) and AES, both of which are in the United States, in a 660-MW natural gas-fired power plant. Also, Southern California Edison's (SCE Corp) affiliate Mission Energy acquired First Hydro Company and its Derwent power project.

Central and South West (Seeboard's parent company) and AES, both of which are in the United States, in a 660-MW natural gas-fired power plant. Also, Southern California Edison's (SCE Corp.) affiliate Mission Energy acquired First Hdro Company and its Derwent power project.

There have also been some foreign investments in Northern Ireland following the auction of all power stations to private companies in March 1992. Two coalfired plants were bought by NIGEN, a consortium of the U.S. company AES and the Belgian company Tractabel. In addition, British Gas bought an oil-fired plant. ${ }^{211}$

\section{Nuclear Power Privatization}

One of the more controversial aspects of electricity privatization in the United Kingdom concerned the governments sale of nuclear power plants. Nuclear power privatization has been a controversial issue in several other countries, in addition to Britain, most notably in Argentina and in Canada. In July 1996, eight of Britain's nuclear power plants were consolidated into one company, British Energy, and then sold off to the public. The privatization of British Energy results in the first publicly-traded company whose entire asset base consists of nuclear power facilities. An earlier attempt at privatization of Britain's nuclear power industry was made in 1990. However, that attempt failed largely as a result of the financial communities' concerns over the safety and liability of nuclear power plants.
As a result of such concerns, during its initial offering, the $\$ 2.1$ billion value the market placed on British Energy proved even less than the cost of building its last nuclear power plant. Further, since the flotation of shares, the market value has dropped even further. In addition to safety and liability concerns, the relatively high operating costs of British Energy has raised doubts over the com pany's ability to compete--particularly in the new competitive free market atmosphere.

\section{Natural Gas Privatization in the United Kingdom}

The privatization of the British natural gas industry is both coincident to and strongly related to the privatization of electricity in the United Kingdom. The recent convergence of Britain's electric and natural gas industries has drawn a significant amount of attention from abroad as a possible paradigm of what might result in other countries from totally privatized energy markets.

Natural gas plays an important and growing role in UK energy supply. Between 1989 and 1994, coal production in the United Kingdom had fallen by half, while natural gas production increased 56 percent. ${ }^{212}$ Since 1970, the UK's production of natural gas has grown sixfold. ${ }^{213}$ Consumption patterns of both fuels has largely paralled demand. Between 1989 and 1994, natural gas consumption in the United Kingdom has risen 31 percent, while coal consumption has fallen by 44 percent. $^{214}$

\footnotetext{
211"NI Customers Empowered," Financial Times (February 9, 1996).

${ }^{212}$ Energy Information Administration, Office of Energy Markets and End Use, International Data Base, June 1994.

${ }^{213}$ Energy Information Administration, Office of Energy Markets and End Use, International Data Base, June 1994.

${ }^{214}$ Energy Information Administration, Office of Energy Markets and End Use, International Data Base, June 1994.
} 
Britain's move away from coal-fired power towards natural gas power is the result of the rapidly changing prospects for both industries in the United Kingdom (See Chapter 6, Recent Trends in International Investment and Trade in Coal). The closure of uneconomic coal mines in the United Kingdom is coinciding with the increasingly available natural gas supplies that have come onstream from fields in the North Sea.

Environmental concerns have also promoted the switch to gas as coal burning has long been a major contributant to air pollution in the United Kingdom. Ironically, Britain's natural gas industry's beginnings stem from Britain's early abundance of coal resources from which town gas was manufactured. A network of essentially privatelyowned local gas operations was nationalized in 1948, when the state-owned monopoly British Gas Corporation was created as a vertically-integrated company. However, British Gas was not a major producer of natural gas until the late 1970's, when North Sea production came onstream. Subsequently, British Gas came to represent the gas industry.

Great Britain started to privatize its natural gas industry 10 years ago-shortly after passage of the Natural Gas Act of 1986, which resulted in the selloff of British Gas by the UK government. In addition to privatization; the Natural Gas Act required that British Gas' transmission pipelines provide open access for all sellers of gas. However, the privatization of British Gas did not result in immediate unbridled competition. Rates still remain controlled by a natural gas regulatory body, the British Office of Gas Supply (Ofgas). Essentially, Britain has gradually introduced free markets in natural gas in three stages. In late 1986, the first stage involved allowing large users of natural gas (over 25,000 therms a year) to seek alternative sources of supply. ${ }^{215}$ These users consisted largely of Britain's indiustrial users of natural gas. Next, in August 1992, users of natural gas in excess of 2,500 therms (primarily commercial demand) were allowed to bypass British Gas in favor of other suppliers. Both actions greatly diminished British Gas's share in the market for industrial and commercial uses. The final stage of privatization is currently being implemented and is creating a very different natural gas industry in Britain.

The newly-enacted Gas Act of 1995 introduced competition into the residential gas market. Following passage of the Act, the UK initiated a free market experiment in natural gas distribution by allowing a half million residential and small business consumers in three southwestern counties to choose their natural gas suppliers. ${ }^{216}$ Previously, the sole supplier of natural gas' to these markets had been British Gas. This pilot program is designed to provide a test ground for the eventual deregulation of the entire natural gas market in the UK, scheduled to take place in 1998. As of April of 1996, Ofgas had licensed 10 companies to supply natural gas in the pilot area. The nature of these companies' operations suggests how dramatically the natural gas industry in the UK is evolving.

Included in the ten companies awarded licenses are several U.S. electric utilities and petroleum companies ' from the United States, Norway, France, as well as from the United Kingdom (Table 6). These companies also include some of the UK's recently-privatized regional electrical companies and PowerGen, one of the two recently-privatized power generation companies.

The petroleum companies entering the UK's newlyopened natural gas distribution business have all substantial North Sea natural gas operations. The primary purpose of obtaining these licenses is to integrate their upstream North Sea operations with downstream residential natural gas demand in the UK. Amerada Hess, Amoco, Conoco (DuPont), Phillips, and Texaco of the United States, Statoil and Norsk Hydro of Norway, and TOTAL of France have all obtained licenses or conditional licenses to market natural gas in the newly-opened regions.

A number of electric utility companies (both from the UK as well as from the U.S.) have also set up subsidiaries in the newly-deregulated regions. This may eventually result in the creation of a residential energy utility industry in the UK with a variety of single service and mixed service companies. ${ }^{217}$ This would be a marked difference from the structure of Britain's electric power and natural gas distribution structures in the past, when two single companies (the Central Electricity Generating Board and British Gas) were the primary providers of these services.

Several of the newly-created natural gas distribution companies are subsidiaries of the current twelve regional electric distribution utilities--and are, in some cases,

\footnotetext{
215"Players Line up in Scramble for U.K. Natural Gas Markets,"Oil and Gas Journal (July 24, 1995), p. 12.

216"Players Line up in Scramble for U.K. Natural Gas Markets," Oil and Gas Journal (July 24, 1995), p. 12.

${ }^{217}$ WEFA Energy's European Gas Service, The Public Distribution Sector, A Special Study on Gas Sales to the High Value Domestic and Commercial Sectors (January 1996), p. 7.3.
} 


\section{Recent Natural Gas \\ Distribution License Applicants}

\section{Owner/Nationality}

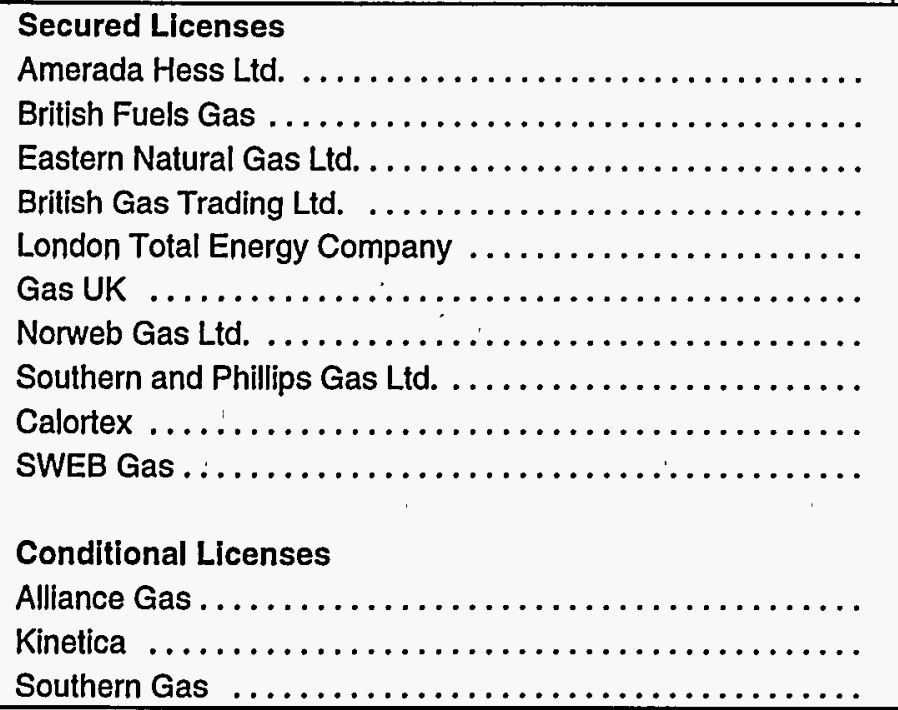

\author{
Amerada Hess (U.S.) \\ Former Subsidiary of British Coal \\ Eastern Group (Hanson) (UK) \\ British Gas (UK) \\ London Electricity/Total Petroleum (UK/France) \\ Northern Electric (UK) \\ Norweb (UK) \\ Southern Electric/Phillips Petroleum (UK/U.S.) \\ Calor/Texaco (UK/U.S.) \\ South Western Electricity ${ }^{2}$ \& Utilicorp (UK/U.S.)
}

${ }^{a}$ South Western Electricity is a subsidiary of U.S. utility Southern Company.

beeboard is a subsidiary of the U.S. utility Central \& South West.

Source: Power Europe, various issues.

foreign-owned. London Electricity, the Eastern Group, Northern Electric, Norweb, Southern Electric, and South Western Electricity have all created natural gas distribution subsidiaries. One former coal company, British Fuels Gas Ltd. (a former subsidiary of British Coal), has also obtained a natural gas distribution license, as has Calor through its joint venture with Texaco. ${ }^{218}$

An additional three companies have been granted conditional licenses: Alliance Gas (a joint venture between British Petroleum and two Norwegian companies), Kinetica (controlled by PowerGen and Conoco UK), and Southern Gas (controlled by Amoco and Seeboard).

The privatization of the UK's natural gas industry has also involved the privatization of the former gas monopoly, British Gas. Privatization of British Gas has had a major impact on the structure of Britain's natural gas industry and on the structure and operating performance of British Gas. One facet of the 1986 Natural Gas Act allowed independent producers to market gas, which resulted in a greatly reduced British Gas share of the U.K. natural gas market. Greater competition spurred British Gas to reorganize. In 1994, British Gas split itself in two separated businesses. Transco, by far the larger of British Gas' two newly-created businesses, consists of British Gas' former natural gas transport and storage business, exploration and production business, and the overseas business. ${ }^{219}$ The other newly-created business, British Gas Energy, consists of the domestic supply arm for 19 million customers, the Morecambe Bay gas fields (which contain 4.5 trillion cubic meters of gas and account for most of British Gas Energy's assets ${ }^{220}$ ), and the service and retail gas business.

British Gas has subsequently looked overseas for growth. In 1995, British Gas merged purchased shares in NGC Corporation, a major purchaser, marketer, and transporter of natural gas in North America. ${ }^{221}$ British Gas is currently building pipelines in South America and planning natural gas distribution facilities in India and Thailand. British Gas is also pursuing natural gas transmission and distribution, and electrical power opportunities in Indonesia, Pakistan, the Philippines, and Vietnam.

\footnotetext{
${ }^{218}$ Calor is a major marketer of liquefied petroleum gases in the United Kingdom.

219"The Break-up of British Gas: Setting up Defense of the Domestic Realm--British Gas Energy," Financial Times (February 7, 1996), p. 22.

${ }^{20}$ "The Break-up of British Gas: Setting up Defense of the Domestic Realm--British Gas Energy," Financial Times (February 7, 1996), p. 22.

${ }^{21}$ British Gas, Annual Report and Accounts 1995, pp. 3-18.
} 
British Gas' experience with privatization in many ways resembles the experience that a number of natural gas transportation companies have undergone as a result of deregulation in the United States. For instance, compounding British Gas's introduction to market forces has been the burden of "take-or-pay" contracts. ${ }^{222}$ Prior to its privatization in 1986, British Gas entered into a number of long-term contracts with North Sea producers--agreeing to set prices for 25-30 years. However, in the meantime, an oversupply of North Sea gas, coupled with the entree of new competition, put downward pressure on domestic natural gas prices in the United Kingdom. As a consequence, British Gas is operating under the burden of having accumulated several billion dollars worth of takeor-pay liabilities.

\section{Finland, Norway, and Sweden}

In Scandinavia, substantial progress in privatizing electricity has occurred and the beginnings of an interregional electricity market are currently underway. Thus far, Finland and Sweden have agreed to the creation of a broad electricity market encompassing all of the Scandinavian countries.

After the United Kingdom, Norway has been the most aggressive of the European countries in introducing competition into electricity markets. Norway deregulated its electricity markets in 1991 and 1992. The 1990 Norwegian Energy Act, which became effective in January 1991, calls for increased competition in the production and sale of electricity. It also allows consumers to select their suppliers. Statkraft, the state power company, was divided into two independent government-owned companies; a production company (Statkraft SF) and a transmission company (Statnett SF). Since privatization, there have been some regional mergers in Scandinavian electricity. In April of 1996, Norway's Statkraft bought into Sweden's Sydkraft for $\$ 179$ million. ${ }^{223}$

Sweden is moving toward competitive generation and distribution markets at local, regional, and national networks. Several foreign investors have shown an interest in acquiring Sweden's electricity assets.

In addition to the Statkraft purchase, France's Electricity de France acquired a 25-percent stake in Graninge, and
Germany's Preussen Elecktra acquired a 12-percent share. ${ }^{224}$ Graninge is Sweden's sixth largest power producer. ${ }^{25}$ Imatran Voima (IVO), the state-owned Finish power company, acquired a 50-percent share of Gullspangs Fraft, another Swedish utility. ${ }^{226}$

In Finland, electricity legislation took effect for the first time in June 1995, removing licensing requirements for power plant construction, power sales to ultimate customers, and imports and exports of electricity. Mandated transmission access and unbundling of various functional activities were also required under the legislation. A regulatory body will be established for oversight of the transmission network. The Finnish government also announced that it is considering the privatization of the state-owned utility IVO. IVO has become active in several cross-border electricity investments. In addition to its Swedish investment, IVO has also invested in independent power projects in the United Kingdom.

\section{France, Italy, and Portugal}

Electricity privatization efforts have been meager in France relative to other European countries. Electricity generation, transmission, and distribution is dominated by Electricity de France (EdF), the state-owned electricity monopoly. Electricity de France is Europe's largest electricity company and nuclear power producer. (Nuclear power accounts for three quarters of France's electricity generation.) A French government commission recently made some recommendations which would have lessened the dominant role of EdF in electricity; however, there appears to be little chance of any far-reaching reform. Although privatization of EdF seems unlikely, $\mathrm{EdF}$ has become a major investor in several independent power projects overseas. EdF has recent power project investments in Hungary, Spain, the Ivory Coast, Argentina, Portugal, Italy, and Poland. In May 1996, EdF purchased a 25-percent interest in the Swedish power company, Graninge. ${ }^{27}$

Italy is preparing for the privatization of its state-owned electric utility, Ente Nazionale per 1'Elergia Eletrica (ENEL). The plans call for splitting ENEL into separate companies, one for transmission and one for distribution activities.

\footnotetext{
222"Pressure Rises As British Gas Puts Government in the Dock," The Times (July 26, 1996).

223 "Norwegian Utility Buys Shares in Swedish Nuclear Operator," Nuclear Week (April 18, 1996), p. 8.

${ }^{24}$ "StatKraft Snaps up 8\% Sydkraft Stake in Nordic Consolidation," European Energy Report (April 12, 1996).

${ }^{25}$ "Sweden Industry: Foreign Interest in Energy Firms Heats Up," EIU ViewsWire (May 23, 1996).

206"EdF Preussen Elecktra and IVO Swoop in Raids on Swedish Utility," European Energy Report (April 26, 1996).

227"Sweden Industry: Foreign Interest in Energy Firms Heats Up," EIU ViewsWire (May 23, 1996).
} 
In 1994, Portugal began to implement a process that would liberalize and eventually partially privatize the nation's electric utility industry. Portugal recently separated its state-owned utility, Electricode de Portugal, into three separate companies for the generation, transmission, and distribution of electricity. However, the intended privatization is targeted to encourage individuals and institutional investors to purchase shares of electricity companies rather than to encourage wholesale purchases by other energy companies. ${ }^{228}$ Since liberalization, a consortium led by National Power of the UK, along with Endesa of Spain, EdF de France, and the U.S. construction firm Morrison-Knudsen, has purchased a power station. PowerGen and Siemens of Germany have acquired a stake in Turbogas "to design, build, own, and operate a $990 \mathrm{MW}$ combined cycle gas turbine power plant. $^{2229}$

\section{Hungary, Poland, Russia, and the Czech Republic}

The traditional electricity industries in Eastern Europe (Bulgaria, Czech Republic, Hungary, Poland, Romania, and Slovakia) are vertically integrated monopolies controlled by central governments, but reforms have started in some countries with respect to structure, ownership, and regulation. Countries where reform has been initiated include Hungary, Poland, Russia, and the Czech Republic, Reforms are considered necessary by some nations to ensure the availability of foreign funds needed to upgrade and expand the power industry.

Among Eastern European nations, Hungary has adopted the most ambitious privatization program for its electrical utility industry. In 1991, the state-owned electricity company was converted to a corporation (MVR). MVR became a holding company for six regional power distribution companies. ${ }^{230}$ Subsequently, Hungary sold the six power distribution companies and all generation assets, except for nuclear power and the transmission grid. $^{231}$ Several major foreign companies bid for ownership of these companies, although Powerfin, a unit of the Belgium company Tractebel, a consortium of German firms, and Electricity de France were the winning bidders. ${ }^{232}$ PowerGen was the first company to purchase an independent power producer in Hungary and Tenneco is currently negotiating an independent power producer purchase. ${ }^{233}$

Poland has disaggregated its power sector and now allows competition among independent generation companies. However, the power generation market is still subject to a variety of regulatory requirements. ${ }^{234}$ Also, independent transmission and distribution companies have been created that operate separately from generating companies. Privatization of electricity generation and distribution is also being considered, although the government plans to maintain 51-percent ownership of the transmission grid. Thus far, Electricity de France has invested in a 450-megawatt coal-fired plant in Krakow, Poland. 235

Russia began a decentralization program in 1993 that will allow 75 percent of its generating capacity to be under the responsibility of the regional power companies and their regulatory bodies. The Czech Republic is privatizing its national generation and transmission company, and plans have been made to privatize regional distribution companies.

\section{Australia}

Through a reform process that was initiated in 1991, the Australian government committed itself to a completely competitive power market by 1999 , encompassing the development of independent interstate transmission networks and competitive power generation. The impetus for utility reform came from the Australian National Commission, which saw considerable benefits from the privatization of state-owned utilities. This Commission recommended that ending scores of monopolies would substantially increase national output and employment, while reducing electricity prices and restraining overall inflation. ${ }^{236}$

Until recently, almost all electricity companies in Australia were owned by state governments. Thus far, the state of Victoria (Australia's second most populous state) has been the most aggressive of the state

\footnotetext{
228" "World Power Service,". Western European Power Report, WEFA Energy, p. 14.3.

${ }^{229}$ PowerGen PLC, Report and Accounts 1995, p. 10.

${ }^{230}$ International Association for Energy Economists Newsletter (Winter 1996), p. 26.

231 "International Privatization: Weighing the Risk of Build versus Buy," Electrical World (November 1995), p. 25.

232" Power \& Energy: Hungary," EIU Business Eastern Europe, (January 1, 1996).

${ }^{233}$ Bennett, Neil, "PowerGen goes to Hungary," The Sunday Telegraph Limited (June 30, 1996), p. $2 \mathrm{ff}$.

234"European Market Transition," Independent Energy (December, 1995), p. 47.

235"Mixed Progress for Polish Power as World Bank Arrives," East European Energy Report (May 22, 1995).

${ }^{236}$ Holdstock, Graham, "Australia's Painful Transition," International Herald Tribune (September 25, 1995).
} 
governments in privatizing its state-owned energy industries. In 1995, Victoria began to privatize its electric power industry, in part in a manner modeled after the British electric industry privatization program. Prior to privatization, the Victoria state government merged 29 electricity distribution companies into five companies, while splitting the state generating company into five enterprises, each with a power station.

The year 1995 saw the first wave of privatization of Victoria's electric power industry. That year, Victoria sold off all of their electric power distribution companies, ${ }^{237}$ raising $\$ 6.7$ billion in the process. ${ }^{238}$ All were purchased (at least in part) by U.S. companies (Table 7). Victoria's power generation facilities are due to be privatized in 1996. For some of the U.S. companies involved, these Australian purchases constituted their first overseas investments. The first sale involved Utilicorp's 49.9percent purchase of United Energy (Utilicorp's Australian partners were Australian Mutual Provident Society and the State Authorities Superannuation Board) for $\$ 1.2$ billion. ${ }^{239}$ The next purchase involved General Public Utilities, purchasing fifty percent of Solaris Power for $\$ 713$ million, plus an additional $\$ 110$ million in franchise fees. ${ }^{240}$ Subsequent transactions included Texas Utilities' purchase of Eastern Energy for $\$ 1.6$ billion, PacifiCorp's purchase of Powercor for $\$ 1.6$ billion, ${ }^{241}$ and Entergy's purchase of CitiPower, Ltd., for $\$ 1.2$ billion. ${ }^{242}$

In 1996, Victoria initiated the privatization of its power generation industry. PowerGen of the United Kingdom (itself a recently privatized electricity generation company) won its bid for the Yallourn power generation facility for $\$ 1.8$ billion. ${ }^{243}$ The Yallourn plant supplies roughly one-quarter of Victoria's electricity. ${ }^{244}$ Mission Energy of the United States later purchased the Loy Yang power plant for $\$ 1$ billion. ${ }^{245}$
There have also been some privatization efforts outside of Victoria. Northern States Power (of the United States) purchased a 37-percent equity stake for its services in rehabilitating and operating the 1,680-megawatt Gladstone Plant in Queensland. ${ }^{446}$ SCE Corporation (also of the United States), through its Mission Energy Corporation subsidiary, plans to build a $\$ 111$-million power plant in western Australia. ${ }^{247} \mathrm{Japan}$ 's Sithe Energies is constructing Australia's largest cogeneration plant, a 175-megawatt gas-fired plant near Sydney. The Australian government sold the Moomba/Sydney natural gas transmission pipeline to Australia Gas and Light (51 percent) and Nova Corp of Canada and Petronas of Malaysia (49 percent) for $\$ 535$ million.

\section{India}

India's power sector is moving toward allowing 100percent foreign ownership of generating plants. The Indian government is counting on independent producers to expand electricity capacity to meet desired targets by the end of the century. Annual growth in electricity demand in India is expected to average about 8 to 10 percent for the rest of the 1990s.

The central government has thus far opened up eight power plants to foreign investors. Several of these plants will be owned by U.S. investors. ${ }^{248}$ During 1995, CMS Generation (a subsidiary of CMS Energy, both based in the United States) invested approximately $\$ 11$ million in GVK Industries, the developer of a 235-megawatt gas/naptha-fired plant under construction in the state of Andhra Pradesh. CMS Generation has a total equity commitment to the project of approximately $\$ 20$ million, representing a 25-percent ownership interest. ${ }^{249} \mathrm{AES}$ is

237" Oregon-based PacifiCorp to Buy Australian Utility," Associated Press (November 16, 1995).

${ }^{238}$ West, Gary, "Australia's Biggest Asset Sell-Off Powers On," The Reuter Asia-Pacific Business Report (November 19, 1995).

${ }^{239}$ Utilicorp's ownership interest was \$258 million. See "Utilicorp Says Earnings of Australian Electricity Operations Exceed Expectations," Business Wire (May 15, 1996).

240"T.U. Beats out PG\&E and PacifiCorp for Eastern Energy of Australia," Electric Utility Week (November 13, 1995), p. 15.

24I"PacifiCorp to Purchase Australian Distributor Powercor for $\$ 1.6$ billion," Electric Utility Week (November 20, 1995 ), p. 15.

${ }^{242}$ Fortnightly (May 1, 1996), p. 7.

243"Australian Privatization: Shaken But Not Stirred," Power Asia (April 1, 1996).

244"PowerGen Beats U.S. Utility Affiliates Vying for 1,450 MW Plant in Australia," Electric Utility Week (March 11, 1996), p. 15..

245"Victoria's Powercor Falls into American Utility Hands" Power Asia (November 27, 1995).

${ }^{246}$ "NSP Unit, Transfield Sign 180-MW Power Sales Pact in Australia," Electric Utility Week (January 8, 1996), p. '18.

${ }^{247}$ The San Diego Union-Tribune (February 25, 1995), p. C-1.

${ }^{248}$ These investor companies are: Cogentrix, Bechtel, AES Corp, CMS Energy Corp, Enron, Enserch, General Electric Company, GVK USA, Houston Industrial, Solarex, and Spectrum Corporation.

${ }^{249} \mathrm{CMS}$ Energy Corporation, 1995 Form 10-K, p. 15. 
Table 7. Australian Electric Utility Privatization-Related Mergers, Acquisitions, and IPP's (U.S. Dollars)

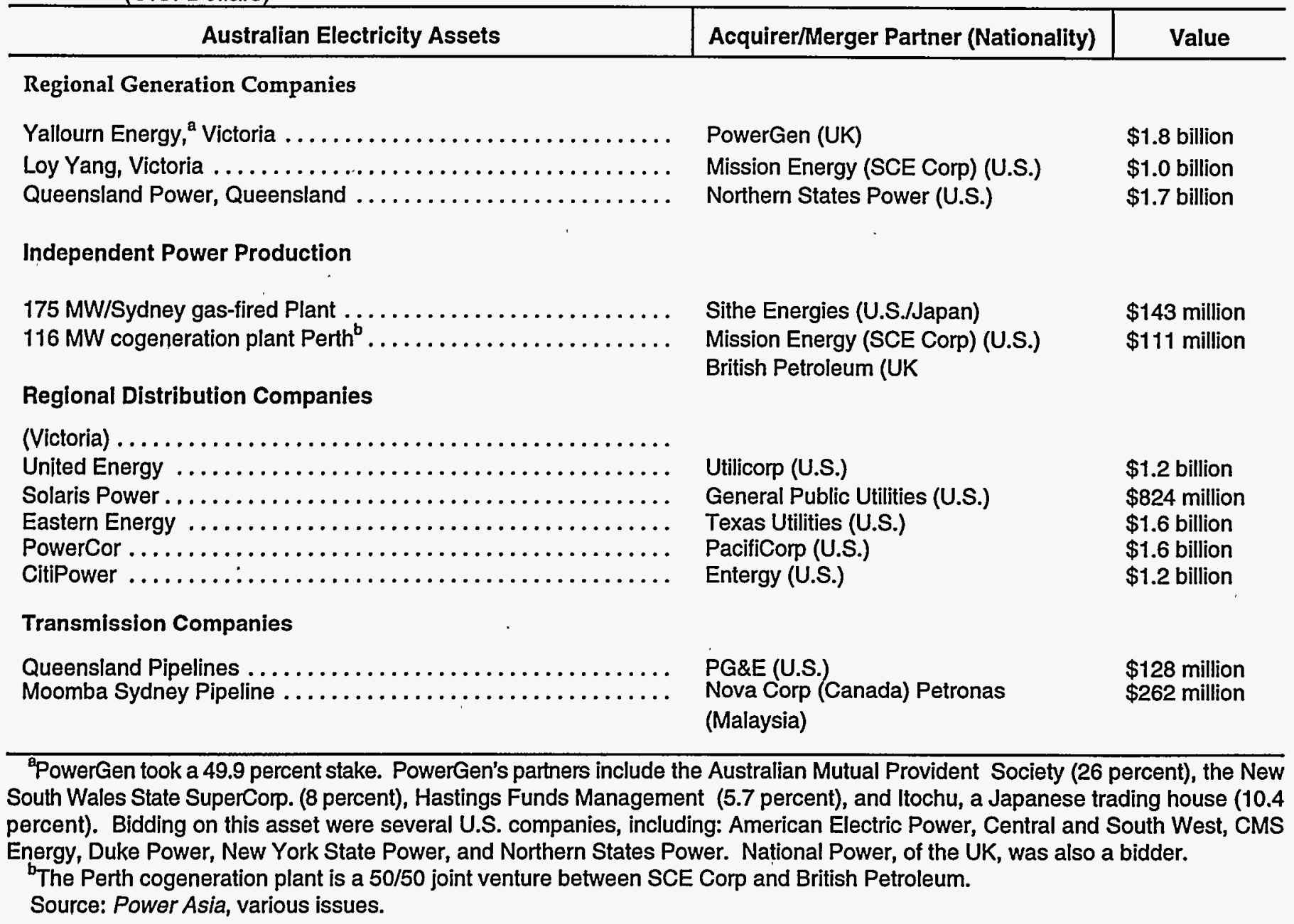

building a \$633-million, 420-megawatt coal-fired power project in Orissa. ${ }^{250}$ Bechtel signed a Memorandum of Understanding for a joint venture with an Indian company to develop up to 1,000-megawatt of renewable energy capacity by the year $2000 .^{251}$ Cogentrix signed an agreement for the purchase of electricity. Houston Industries is close to completing a deal to develop a 45megawatt power plant in India. The company is already developing a \$700 million 500-megawatt coal-firedplant. ${ }^{252}$ Enserch signed a Memorandum of Understanding for a \$450-million, combined cycle power plant in Kerala. ${ }^{253}$

Recently, a widely-publicized dispute between Enron and the Indian state government of Maharashtra underscored the potential conflicts that might arise between foreign investors and host governments. In 1995, a newly-elected nationalist Maharashtra state government decided to cancel a $\$ 2.8$-billion power plant developed by the Enron Corporation after Enron and its partners (Bechtel Enterprises and the General Electric Company) had already spent $\$ 300$ million. The newly-elected government alledged that the previous government had secretly negotiated the contract with Enron under terms that favored Enron and disadvantaged consumers. The cancellation had the effect of jeopardizing the credibility of India's economic reform program. ${ }^{254}$ Enron later succesfully renegotiated a deal with the state government in early 1996, which called for a reduction in electricity

${ }^{250}$ U.S. Department of Energy, Office of Oil and Natural Gas Policy. ${ }^{251}$ U.S. Department of Energy, Office of Oil and Natural Gas Policy.

${ }^{252}$ U.S. Department of Energy, Office of Oil and Natural Gas Policy. ${ }^{253}$ U.S. Department of Energy, Office of Oil and Natural Gas Policy. 254"Wattage to India," The Washington Post (February 5, 1996), p. A12. 
rates and allowed the project to proceed. Enron and its solar joint venture partner, Amoco's Solarex, are also in the planning stage of a $\$ 100$-million 50-megawatt solar power plant to be built in Rajasthan. ${ }^{255}$.

\section{Pakistan}

Pakistan's five-year plan (1993-1998) called for $\$ 10.5$ billion in electric power generation investment. ${ }^{256}$ Pakistan faces enormous new electricity generation capacity needs. To meet its growing power needs, Pakistan has actively encouraged investment to build private sector power plants. Pakistan also plans to privatize its stateowned electric utilities. ${ }^{257}$ In addition, the Pakistani government is encouraging build-operate-transfer (BOT) agreements, both for new power projects and for some of the thermal power stations managed by the country's major utility. The first major project involving foreign investment is the 1,292-megawatt Hub Power Company plant. ${ }^{258} \mathrm{Hub}$ is due to be completed in 1997. A consortium of domestic and foreign companies have provided funding for Hub Power, prominent among them are National Power (of the United Kingdom), which took a 25percent share; Xenel (of Saudi Arabia), which took a 15percent share; and Entergy (of the United States), which took a 10-percent share.

Pakistan is benefiting from World Bank financing through a BOT scheme to develop another major electricity project, the Hab River project, which will consist of four oil-fired 323-megawatt units. A consortium of domestic and international companies has provided the financing for Hab River led by the recently-privatized electric utility Midlands Electricity PLC, of the United Kingdom. ${ }^{259}$

By 1966, Pakistan had reached financial closure on at least 10 independent power projects. Foreign investors involved in these projects include AES Corp (of the U.S.), Tomen (of Japan), Japan Power Generation, and Southern Electric Power (of the United Kingdom). AES raised $\$ 560$ million in financing and began construction on two 337megawatt oil-fired power plants in Pakistan. ${ }^{260}$ In addition, a joint venture oil-fired power plant between
Enron and Bechtel is in the financing stage. ${ }^{261}$ Other recent foreign energy investments in Pakistan include several renewable projects, such as wind power, solar, and hydro.

\section{China, New Zealand, Indonesia, the Phillippines, and Morocco}

Between 1990 and 2010, China is expected to almost triple its consumption of electricity. China recently opened its power sector to foreign investment. Several joint ventures have already been established for the construction of electric generating units. China is modifying its legal framework to allow the possibility of full foreign ownership of power plants. In at least one project a buildownership-transfer financing arrangement is being tested. Coastal constructed a 40-megawatt power plant in Wuxi City and began construction on a 76-megawatt power plant in Suzhou, and plans a 72-megawatt plant in Nanjing. ${ }^{262}$ Enserch reached an agreement to cooperatively develop and operate a 36-megawatt coal-fired plant near Zhejiang. ${ }^{263}$

New Zealand started to privatize its electric power industry in 1987, in the midst of an ambitious attempt to transform the economy to a greater free-market economy. A transmission corporation was created in 1993, and monopolies in local distribution and retailing were eliminated. In 1995, the New Zealand government issued a new electricity policy designed to create a competitive power market. The policy puts a limit on how much new capacity the state-owned Electricity Corporation of New Zealand (ECNZ) can build in the future, requiring at least 1.5 gigawatts of new capacity to be built by the sector over the next few years. In January 1996, ECNZ was split into two companies, with ECNZ retaining most of its power generation. Over the past few years, a number of New Zealand's electric utilities have been purchased by U.S. utilities. IES Industries took a minority interest in Powerco Limited and Central Power Limited. ${ }^{264}$ Further, Utilicorp purchased 20 percent of the common stock in Power New Zealand, ${ }^{265}$ New Zealand's second largest electric distribution company.

\footnotetext{
25s"Business Brightens for Solar Power Manufacturer Solarex," Associated Press (April 23, 1996).

${ }^{256}$ Energy Information Administration, Country Energy Profile, Pakistan (September 1994)

${ }^{257}$ Energy Information Administration, Country Energy Profile, Pakistan (September 1994).

${ }^{258}$ Energy Information Administration, Country Energy Profile, Pakistan (September 1994).

${ }^{259}$ Uch Project on a Knife Edge," Power Asia (October 30, 1995).

${ }^{200}$ AES Corporation, 1995 Annual Report, p. 3.

${ }^{251}$ Enron Corp, 1995 Annual Report, p. 26.

262."Coastal Subsidiary's Joint-Venture Opens Power Plant in China," Business Wire (December.12, 1995).

263" "Enserch, Two Partners Sign Deal for 36-MW Power Plant in China," Independent Power Report (March 10, 1995 ), p. 12.

264 "IES Makes Investment in New Zealand Companies," PR Newswire (October 3, 1995).

${ }^{265}$ Utilicorp, 1995 Annual Report, p. 43.
} 
Until recently, the Indonesian state electric utility, PLN, was responsible for most electric power generation, transmission, and distribution. In 1990, the Indonesian government announced that it would actively encourage private investment in power generation, including that from foreign investors. Later, the government established three operating subsidiaries. These operating subsidiaries are slated to go public in 1997 and their shares will be traded on the New York Stock Exchange. ${ }^{266}$ These companies will be free to compete and create strategic alliances with foreign companies in the growing number of independent power projects that are currently underway.

Independent power projects in Indonesia are generally financed through BOT arrangements. ${ }^{267}$ Indonesia's rich variety of energy resources provides an array of economical fuels to power electricity generation. The largest projects currently planned (Paiton 1 and Paiton 2) will consist of coal-fired power plants and involve investment from General Electric and Mission Energy (both of the United States), Mitsui (of Japan), Siemens (of Germany), and PowerGen (of the United Kingdom). Duke-and Fluor Daniel (both of the United States) have been contracted to build Paiton 1.

In the Phillippines, the power sector is characterized by continuous outages due to insufficient electricity supply. Like Indonesia, the Phillippines plan to rely heavily on private investment through BOT agreements. By the end of 1993, a total of 27 contracts had been awarded for the construction of power plants. The Philippines are planning to restructure and to privatize the National Power Corporation, the country's main state-owned utility.

One of the largest foreign investors in Philippine electricity is the Hong Kong-based company Hopewell. Hopewell is providing full financing for three oil and coalfired projects totaling 1,700 megawatts and partial (49 percent) funding for a 734-megawatt coal-fired plant. In March 1996, it was reported that Enron is bidding on an \$800-million, 1200-megawatt gas-fueled power plant that is to be operating in 1999..$^{268}$ California Energy (of the
United States) has undertaken three geothermal projects expected to provide an additional 500 megawatts of power. ${ }^{269}$

Other major foreign-investor led power projects in the Philippines include a 93-megawatt coal and oil-fired unit in Mindano, led by CMS Energy (of the United States), and a 60-megawatt oil-fired unit financed equally by Tomen (of Japan), General Electric Capital (of the United States), and Wartsila Diesel (of Finland).

Morocco's reform of its electricity sector maintains the current state-owned electricity distribution monopoly (Office National de $1^{\prime}$ Electricite). However, private companies are now allowed to generate power for sale. ${ }^{270}$ In April, 1996 CMS Generation's (of the United States) independent power unit finalized an agreement with the Office National de l'Electricite. CMS and its 50-50 partner Asea Brown Boveri Energy Ventures (the Swedish-Swiss conglomerate) will each hold concession rights and an agreement to sell electricity to the Office National de $1^{\prime}$ Electricity for 30 years. ${ }^{271}$ The total cost of the initial acquisition and the additional 660 megawatts will be $\$ 1.3$ billion. Two other private-power projects in Morocco are pending. ${ }^{272}$

\section{Argentina}

In terms of the number of companies with active investments, Argentina holds the greatest interest among all Latin American countries for foreign firms. A total of 28 companies have active projects underway in Argentina (Table 8). Argentina already has sold more than 9,000megawatts of generating capacity and could sell as much as 7,500 additional megawatts. A 2,700-megawatt hydroelectric plant is currently being offered to buyers. ${ }^{273}$ Much additional generating capacity, transmission systems, and other portions of the electricity industry are expected to be offered for sale soon. ${ }^{274}$

Electricity companies and oil and gas companies (chiefly from Chile and the United States) constitute almost all foreign investment in Argentine power generation. The

${ }^{266}$ WEFA Energy, World Power Service, Far East Report, p. 4.6.

${ }^{267}$ WEFA Energy, World Power Service, Far East Report, p. 4.7.

${ }^{268}$ U.S. Department of Energy, Office of Oil and Natural Gas Policy.

${ }^{269}$ "Eximbank and Opic Fund Phillippines Geothermal Energy Plant," International Trade Finance (August 26, 1994).

270" "Globalization of the Electric Power Industry: Risks and Opportunities," Electrical World (January 1995), p. 40.

271"ABB, U.S.'s CMS Sign \$1.6 Billion Morocco Electricity Franchise Deal," AFX News (April 26, 1996).

272 "Globalization of the Electric Power Industry: Risks and Opportunities," Electrical World (January 1995), p. 40.

${ }^{273}$ This sale is expected to generate $\$ 1.8$ billion. See "Argentina: Yacyreta Privatization Plan Causes Controversy." Inter Press Service (January 11, 1996).

${ }^{274}$ Javetski, John, "International Privatization: Weighing the Risk of Build v. Buy," Electrical World, Vol. 209 (November 1995), pp. 25ff. 
Table 8. Latin American Electricity Investment for Argentina,'Bolivia, Chile, Colombia, and Peru, by Company and Country

\begin{tabular}{|c|c|c|c|c|c|}
\hline Company & Argentina & Bolivia & Chile & Colombia & Peru \\
\hline ABB Energy Ventures (Sweden) $\ldots$ & & & & GFE & \\
\hline AES Corp (U.S.) $\ldots \ldots \ldots \ldots \ldots \ldots \ldots \ldots \ldots \ldots \ldots$ & HE & i & & & \\
\hline 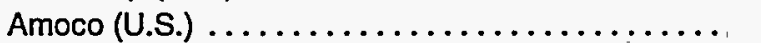 & $P G$ & & & & \\
\hline British Gas (UK) $\ldots \ldots \ldots \ldots \ldots \ldots \ldots \ldots \ldots \ldots$ & $P G$ & & & & \\
\hline Catalyst Energy Corp. (U.S.) $\ldots \ldots \ldots \ldots$ & & GFE & & & \\
\hline Chilgener (Chile) $\ldots \ldots \ldots \ldots \ldots \ldots \ldots$ & OFP/GFE, HE & & & & \\
\hline Chilquinta International Inc. (Chile) ........ & OFP/GFE & & & & EPD \\
\hline n............... & $-P G, E P D, P G$ & & & & \\
\hline Citicorp Capital Investors (U.S.) . ........ & GFE, EPD & & & & $?$ \\
\hline Citizens Power \& Light (U.S.) . . . . . . . . . . . . . . & & & & CFP & \\
\hline CMS Energy (U.S.) $\ldots \ldots \ldots \ldots \ldots \ldots \ldots \ldots \ldots$ & HE, OFP/GFE & & & & \\
\hline Cogenerex (U.S.) $\ldots \ldots \ldots \ldots \ldots \ldots \ldots \ldots \ldots, \ldots$ & & $P G$ & & & \\
\hline Constellation Energy (U.S.) $\ldots \ldots \ldots \ldots \ldots \ldots$ & & PG & & & \\
\hline Dominion Resources (U.S.) $\ldots \ldots \ldots \ldots \ldots \ldots$ & GFE & HE & & & \\
\hline Duke Power (U.S.) $\ldots \ldots \ldots \ldots \ldots \ldots \ldots \ldots \ldots$ & GFE, HE & & GFE & & \\
\hline Electricity de France (France) $\ldots \ldots \ldots \ldots$ & HE, EPD, EPT & & & & \\
\hline Endesa (Chile) ......... & EPD & & & & HE, EPD \\
\hline Enersis S.A. (Chile) ... & GFE, PG, EPD & & & & PG, EPD \\
\hline Enron (U.S.) $\ldots \ldots \ldots \ldots \ldots \ldots \ldots \ldots \ldots \ldots \ldots$ & GFE & & & & \\
\hline Entergy Corp. (U.S.) $\ldots \ldots \ldots \ldots \ldots \ldots$ & GFE/OFP, EPT, EPD & $P G$ & PG & & HE \\
\hline General Public Utilities (U.S.) . & & $P G$ & & GFE & \\
\hline Houston Industries Inc. (U.S.) . & CG, GFE, EPD, EPT & & & & \\
\hline Iberdrola (Spain) $\ldots \ldots \ldots \ldots \ldots \ldots \ldots \ldots$ & $P G$ & EPQ & & & \\
\hline K \& M Engineering and Consulting (U.S.) & & & & GFE & \\
\hline LG\&E Energy Corp. (U.S.) ................. & GFE & & & & \\
\hline LOS W S.A. (Chile) & GFE, EPD & & & & \\
\hline National Electric of Chile (Chile) .............. & $P G$ & & & & \\
\hline Northeast Utilities (U.S.) $\ldots \ldots \ldots \ldots \ldots \ldots \ldots \ldots$ & GFE, PG, CG & & & & \\
\hline Northern States Power (U.S.) $\ldots \ldots \ldots \ldots \ldots \ldots \ldots$ & & & & PG & \\
\hline NRG Energy (U.S.) $\ldots \ldots \ldots \ldots \ldots \ldots \ldots \ldots \ldots \ldots$ & & & & PG & \\
\hline Nucleamiento Inversor S.A. '(Chile) & HE,EPT & & & & \\
\hline Ontario Hydro (Canada) .... & & & & & EPD \\
\hline PSI Resources (U.S.) ....... & GFE/OFP, EPD & & & & \\
\hline Sevillana Electricidad (Spain). & & & & CFP & \\
\hline Societe Urbain (Chile) & EPD & & & & \\
\hline Southern Company (U.S.) $\ldots \ldots \ldots \ldots \ldots \ldots \ldots$ & & & PG, EPT & & \\
\hline Southwestern Public Service (U.S.) . . . . . . . & $P G$ & & & & \\
\hline
\end{tabular}

$\mathrm{CFP}=$ coal-fired plant; $\mathrm{CG}=$ cogeneration; $\mathrm{EPD}=$ electric power distribution; $\mathrm{EPT}=$ electric power transmission; $\mathrm{GFE}=$ gas-fired electricity; $\mathrm{HE}=$ hydroelectric; $\mathrm{OFP}=$ oil-fired plant; $\mathrm{PG}=$ power generation (fuel unknown.

Sources: Various company Annual Reports; the Mead Corporation, Lexis-Nexis, and Disclosure Incorporated, Compact Disclosure.

Chilean companies, all of which are primarily electricity companies, are Chilgener, Chilquinta, Enersis S.A., and National Electric of Chile. The U.S. oil and gas companies are Amoco and Enron. The U.S. electricity companies are Cinergy, CMS Energy, Dominion Resources, Duke PowerEntergy Corp, Houston Industries, LG\&E, Northeast Utilities, PSI Resources, and Southwestern Public Service.

\section{Bolivia}

Bolivia's new Electricity Law requires the separation of electricity generation, transmission, and distribution. Any companies engaged in one of these activities is required by the law to divest itself of the other activities. Thus, Bolivia, which already privatized its state electric utility, 
Ende, is potentially restructuring all private firms engaged in their electricity industry.

The sale of its state electrical utility, Ende, made Bolivia one of the first South American countries to allow private investors to enter its domestic electricity market. Ende was broken into three regional generating companies, each of which was purchased by a different foreign company. The purchasers were almost without exception U.S. companies (Table 8). The U.S. companies Dominion Resources and Energy Initiatives (an affiliate of General Public Utilities) each bought one of the three regional companies. The third regional company was purchased by a consortium headed by the Canadian company Bolivian Generating Group, but included Baltimore Gas and Electric and Pennsylvania Power and Light. 275 The regional companies averaged 174 megawatts of generating capacity and split 50 percent of ownership amongst themselves (with Bolivia retaining the other 50 percent ownership share) in exchange for an average of $\$ 47$ billion and the assumption of $\$ 38$ billion of debt. The purchasers will operate their plants for 5 years and also have exclusive rights to build any new generating facilities for domestic or export markets.

In addition to the privatization of Ende a few other projects are underway. Most of these projects involve U.S. electricity companies, including Catalyst Energy Corp, Cogenerex, Entergy, and General Public Utilities. Additionally, the Spanish electricity company Iberdrola has made a power distribution investment.

\section{Chile}

Currently, there is little investment by foreign companies in Chile's electricity industry. Despite the similarity between Chile's electricity deregulation and the deregulation/privatization in Argentina, Bolivia, and Peru, notably less investment has been made in Chile. Perhaps part of the reason is that Chile's privatization preceded these countries' privatizations by several years. Chilean electricity companies, however, are making numerous investments in other Latin American countries' electricity industries.

Some foreign investment is occurring in Chile. Southern Company, through its international affiliate, Southern Electric International, increased its ownership in the northern Chilean generation and transmission utility, Edelnor. Further, Chile's state copper company is offering 25 percent of one of its power plants for sale. Other companies with investment projects in Chile include the U.S. electric companies Duke Power, which invested in gas-fired power generation, and Entergy, which invested in power generation (Table 8 ).

Although little foreign investment in Chilean electricity currently exists, a substantial increase in its generating in capacity may occur in the next few years. By October 1995, four U.S. companies had announced plans to build four gas-fueled plants in Chile. ${ }^{276}$

\section{Colombia and Peru}

In Colombia, an effort to sell the state utility has begun. Colombia's congress has approved a privatization plan, which affects at least 25 companies in many industries, including the hydro and thermoelectric industry. ${ }^{2 \pi}$ Foreign companies actively investing in Colombia include ABB Energy Ventures (Sweden/Switzerland), Citizens Power and Light (United States), General Public Utilities (United States), K\&M Engineering and Consulting (United States), and Northern States Power (United States). All investment is in power generation, most of which is gas-fired (Table 8). One notable exception is the coal-fired generation investment of Citizens Power and Light.

Peru restructured its electricity industry into separate generation, distribution, and transmission companies, as have Argentina, Bolivia, and Chile. ${ }^{278}$ However, unlike Bolivia and Chile, Peru has seen much foreign investment in power distribution, in addition to power generation. Most of the power generation investment has been in hydroelectric generation. The companies active in Peru include the Chilean companies Chilectra, Chilquinta, Enersis S.A., and Endesa; the U.S. company Entergy; and the Canadian company Ontario Hydro (Table 8).

\section{Brazil, Mexico, and Venezuela}

Brazil, Mexico, and Venezuela are similar in that their privatization efforts have been fairly limited. A total of five foreign companies have invested in the electricity industries of Brazil, Mexico, and Venezuela (Table 9).

\footnotetext{
${ }^{275}$ Friedland, Jonathan, "New Jerseyan Has a Bright Idea in Bolivia," The Wall Street Journal (July 27, 1995), p. A8.

${ }^{276}$ Friedland, Jonathan, "Plans by U.S. Utilities to Enter Chile Roil Power Sector With Fears of Glut," The Wall Street Journal (October 18, 1995), p. A16,

${ }^{27}$ WEFA Group, Latin America Monthly Monitor (January 1996), p. 30.

${ }^{278}$ Energy Information Administration, International Energy Outlook 1995 (DOE/EIA-0484(95)) (Washington, DC, May 1995$)$, p. 74.
} 
Table 9. Electricity Privatization Investment in Brazil, Mexico, and Venezuela, by Company and Country

\begin{tabular}{|c|c|c|c|}
\hline Company & Brazil & Mexico & Venezuela \\
\hline AES Corp (U.S.) $\ldots \ldots \ldots \ldots \ldots \ldots$ & 00 & & \\
\hline Central \& South West Corp. (U.S.) ..... & & JV-PG & \\
\hline Community Energy Alternatives (U.S.) . . & & & PG \\
\hline New World Power (U.S.) . . . . . . . . . . . & & PG & \\
\hline PP\&L Resources (U.S.) ........... & & $P G$ & \\
\hline Public Service Enterprise Group (U.S.) & & & IPP \\
\hline
\end{tabular}

$\mathrm{IPP}=$ independent power production; $\mathrm{JV}=$ joint venture; $\mathrm{OO}=$ opened office; $\mathrm{PG}=$ power generation.

Sources: Various company annual reports; The Mead Corporation, Lexis-Nexis; and Disclosure Incorporated, Compact Disclosure.

Brazil enacted a 1993 law that allows large electricity consumers to build and operate their own generating facilities and sell any excess power to a public utility. ${ }^{279}$ A second electricity law is under consideration, which would separate power generation, transmission, and distribution as has been done already in Argentina, Bolivia, Chile, and Peru.

Thus far, no foreign investment has actually been made in Brazilian electricity. The single major electricity sale consumated involved the purchase of a stalled hydroelectric plant by a Brazilian consortium. However, another attempt by Brazil to entice foreign investment may be made soon with the offer of four regional subsidiaries of Electrobras, the Brazilan state utility. Also, AES Corp, a U.S. electricity generator, has opened an office in Brazil, which is one tangible sign of possible future foreign investment.

Mexico's attempt at electricity sector reform has consisted of recently passed legislation allowing private companies to import power supplied as a private service to the private sector. However, any surplus power must be sold to the Mexican state utility company, $\mathrm{CFE} .{ }^{280}$ Central and South West Company, New World Power, and PP\&L Resources (all U.S. companies) have power generation projects underway in Mexico, all of which will sell wholesale power after completion.

Venezuela recently made its third unsuccessful attempt to sell state electric utility assets. Five state-owned generation and distribution companies with a total generating capacity of nearly 5 gigawatts have now unsuccessfully been offered for sale. ${ }^{281}$ Venezuela plans substantial expansion of its power generation capacity, which should provide ample opportunities for foreign investment. ${ }^{282}$ However, only two companies, both based in the United States (Community Energy Alternatives and Public Service Enterprise Group), have currently invested in Venezuelan power generation.

\section{The Dominican Republic and Trinidad}

Due to recent reforms, both the Dominican Republic and Trinidad have privatized their electricity industries.

Although both of these countries are relatively small, they have experienced more foreign investment than many of Latin America's larger economies (Table 10). The Dominican Republic has attracted Coastal and Enron, both U.S. oil and gas companies; Destec Energy, Energy Initiative, and General Public Utilities, all of which are U.S. electricity companies; and Honduras Electric Company. Oil-fired power generation investment was made in all cases.

Trinidad also recently privatized its energy industry. U.S. companies have provided all of the foreign investment in Trinidad's electricity industry. Amoco's investment in oil and gas production in Trinidad appears to have motivated its subsequent investment in Trinidad's electric company. ${ }^{238}$ Southern Company (both directly and through its international affiliate Southern Electric International) has made numerous investments in power generation in Trinidad.

\footnotetext{
${ }^{279}$ Energy Information Administration, International Energy Outlook 1996 (DOE/EIA-0484(96)) (Washington, DC, May 1996), p. 86.

${ }^{280}$ Energy Information Administration, International Energy Outlook 1996 (DOE/EIA-0484(96)) (Washington, DC, May 1996), p. 80.

${ }^{281}$ Javetski, John, "International Privatization: Weighing the risk of build vs buy," Electrical World, Vol. 209 (November 1995), p. 209.

${ }^{282}$ Energy Information Administration, International Energy Outlook 1996 (DOE/EIA-0484(96)) (Washington, DC, May 1996 ), p. 86.

${ }^{283}$ Petroleum Economist (June 1995), p. 125.
} 
Table 10. Electricity Privatization Investment in Costa Rica, Dominican Republic, Ecuador, El Salvador, Guatemala, Honduras, and Trinidad, by Company and Country

\begin{tabular}{|c|c|c|c|c|c|c|c|}
\hline Company & Costa Rica & $\begin{array}{c}\text { Dominican } \\
\text { Republic }\end{array}$ & Ecuador & $\begin{array}{c}\text { EI } \\
\text { Salvador }\end{array}$ & Guatemala & Honduras & Trinidad \\
\hline Amoco (U.S.) & & & & OFP & & & GFE \\
\hline Coastal Corp. (U.S.) $\ldots \ldots \ldots \ldots \ldots$ & & OFP & & & & & \\
\hline Destec Energy (U.S.) ...... & & OFP & & & & & \\
\hline Enron (U.S.) .................. & & PG & & & OFP & & \\
\hline General Public Utilities (U.S.) . . . . . . . & & $P G$ & & & & & \\
\hline Honduras Electric Company (U.S.) .. & & OFP & & & & & \\
\hline Illinova Corp. (U.S.) . .............. & & & & & & PG & \\
\hline Northeast Utilities (U.S.) $\ldots \ldots \ldots \ldots$. & W & & & & & & \\
\hline Southern Company (U.S.) . . . . . . . . . & & & & & & & CFP,PG, GFE \\
\hline Tenneco (U.S.) $\ldots \ldots \ldots \ldots \ldots \ldots$ & & & $P G$ & & & & \\
\hline
\end{tabular}

$\mathrm{CFP}=$ coal-fired plant; GFE= gas-fired electricity; $\mathrm{OFP}=$ oil-fired plant; $\mathrm{PG}=$ power generation (fuel unknown); and $\mathrm{W}=$ wind power generation.

Sources: Various company annual reports; The Mead Corporation, Lexis-Nexis, and Disclosure Incorporated, Compact Disclosure. 
$4=$ 


\section{Recent Trends in International Investment and Trade in Coal}

In recent years, the structure of the world's coal industry has undergone considerable change. European companies--in particular, multinational conglomerates--have increased their presence abroad in recent years. The gradual removal of European coal subsidies may have encouraged this trend. In the United States, as the role of European companies has grown more pronounced, U.S.based industry participants have reduced their role. Prominent among the latter group have been several of the smaller independent coal producers, major U.S. petroleum companies, electric utilities, and domestic steel manufacturers. As in the United States, foreign investment has played a considerable role in Australia, the world's largest exporter of coal.

Coal accounts for 25 percent of global energy consumption, significantly less than crude oil ( 39 percent), but more than natural gas (22 percent). ${ }^{284}$ Ninety percent of coal production is consumed in the country of origin, primarily for the generation of electricity. ${ }^{285}$ Although only about 10 percent of world coal production makes its way into export markets, international trade in coal has grown substantially in recent years. This has been particularly true of steam coal. In 1985, international trade in steam coal and metallurgical coal were roughly equal. By 2005 , steam coal trade is expected to be double metallurgical coal trade. ${ }^{286}$ Between 1973 and 1994, international coal trade doubled and is expected to increase by an additional 50 percent by 2010. A handful of nations--and companies-account for the bulk of this trade. Australia is the largest exporter of coal, followed by the United States and South Africa. In 1994, Japan was far and away the world's largest coal importer, followed by South Korea, Russia, Taiwan, Germany, the Netherlands, and Great Britain. Although the leading world coal-producing companies include some state-owned companies, a handful of multinational conglomerates figure very prominently in worldwide coal trade and investment. These companies are primarily from the United Kingdom, Germany, the United States, and Australia. Interestingly, although Japan is the world's largest importer of coal (and also the largest importer of U.S. coal), Japanese companies have made relatively minor investments in coal assets abroad. Many of the world's largest producers of coal are not publicly traded corporations. Neither are they multinational in outlook. For instance, among the world's largest producers of coal are the national coal companies of Russia, India, and Ukraine.

\section{United States ,}

Foreign investors have become increasingly important in U.S. coal over the past decade or so. The share of foreign affiliates in U.S. coal production has grown from nearly zero in the late 1970's to 29 percent in 1994. In 1994, three of the top five U.S. coal-producing companies were foreign-affiliated, accounting for more than one fifth of total U.S. production. The largest foreign-affiliated producer of coal in the United States (as well as the largest producer of coal in the United States) is Peabody Holding Company. Peabody's parent corporation, the British firm Hanson PLC, is the world's second largest privatelyowned coal producer. The second largest foreign-affiliated producer is Consol Coal, which is also the third largest U.S. coal producer. Consol is a 50-50 joint venture between DuPont and the German company, Rheinbraun AG. Rheinbraun AG is the world's largest privately held coal producer. The third largest foreign-affiliated U.S. coal producer is Kennecott Energy Company, which is owned by the British company, RTZ PLC, the world's biggest mining group. Kennecott is the fourth largest producer of coal in the United States. ${ }^{287}$

A number of factors contributed to the attractiveness of the U.S. coal industry as a target of foreign investment.

\footnotetext{
${ }^{284}$ Energy Information Administration, International Energy Annual 1993, DOE/EIA-0219(93) (Washington DC, May 1995), p. viii.

${ }^{285}$ The Mining Journal (July 1994), p. 105.

${ }^{286}$ Energy Information Administration, International Energy Outlook 1996, DOE/EIA-0484(96) (Washington, DC, May 1996), p. 52.

${ }^{287}$ "Buy Low: Foreigners have been buyers of U.S. coal properties. What do the buyers know that the sellers don't?" Forbes (March 15, 1993), p. 50ff.
} 
For one, the United States is the largest coal market open to foreign investors. In addition to being the second largest exporter of coal, the United States is the world's second largest coal consumer and producer. ${ }^{288}$ Most of the foreign investment in U.S. coal has been from Europe.

European coal companies are motivated in part to invest in U.S. coal in order to secure sources of coal in the face of declining European production. However, this motive is apparently prospective rather than reflective of the current patterns of production and imports of coal. That is, the United Kingdom, which is the largest foreign investor in U.S. coal, ranked tenth among coal importers; Germany, the second largest investor, ranked twentieth. Japan, Canada, France, Spain, Belgium, the Netherlands; and Italy all imported more U.S. coal than the United Kingdom and Germany, but these countries had little, if any, in the way of U.S. coal investments.

Financial incentives are another possible motive for investing in U.S. coal. Were it not for the widespread exit of the U.S. major petroleum companies from domestic coal mining, this motive might appear more plausible. It was largely due to several years of financial under performance among their coal segments that resulted in the majors' departure from U.S. coal. Only three times in the last eighteen years did the majors' profitability in coal exceed the profitability of their consolidated operations. ${ }^{289}$

Possibly the key factor motivating UK and German investors is that as inefficient European mines continue to close, multinational European coal producers have had to move abroad in order to remain in the coal business. As is evident from the discussion below, the United States and Australia (with their extensive coal reserves, established export markets, and few impediments to foreign investors) have gained prominence as targets for coal investments.

\section{Europe}

In Western Europe, coal production is concentrated, with the United Kingdom and Germany accounting for roughly four-fifths of total production and Spain and France accounting for most of the remainder. Until recently, European coal producers benefitted from protected markets and from an extraordinary array of generous subsidies, allowing European coal mines, which had become vastly inefficient by world standards, to remain in operation. In Germany, for instance, subsidies have until recently been financed by a 7.5-percent levy on electricity bills. As a consequence, domestic coal prices in Germany have been more than three times the import price. ${ }^{290}$

In turn, electricity prices in Germany are the most expensive in Europe, and 70 percent more costly than in the United States. ${ }^{291}$ However, the German coal industry has been shrinking in' recent years in order to comply with European Union mandates and to remain competitive in a global market place.

The restructuring of Europe's coal industry is also due in part to a shift to alternative fuels. The proportion of Western Europe's energy consumption fueled by coal fell from around 80 percent in the 1950's to 25 percent in 1994. In the future, European utilities are expected to move toward greater usage of increasingly available North Sea natural gas and away from coal.

As a result of the continued elimination of coal subsidies and shift toward natural gas, the European coal industry has been declining. In 1994, coal production in the United Kingdom declined by over 60 percent from its 1980 level, while Germany experienced a decline of almost 40 percent in hard coal production. The larger reduction in coal output in the United Kingdom was in part due to the more forceful elimination of subsidies undertaken by the British government. Germany has been behind schedule in doing away with coal subsidies. For OECD Europe, hard coal production is expected to fall from 187 million metric tons in 1992 to 80 million metric tons in $2010 .{ }^{292}$

In contrast to Europe, U.S. coal production peaked in 1994 , surpassing 1 billion short tons for the second time in history. U.S. production in 1994 was 25 percent larger than in 1980. Further, in future years, the United States is expected to increase its coal output. Other countries expected to boost coal production and exports in future years include the largest and the third largest coal exporters, Australia and South Africa. Recent entrants into the global coal trade include Colombia and Venezuela.

\footnotetext{
${ }^{288}$ China is both the leading producer and consumer of world coal.

${ }^{289}$ Energy Information Administration, Form EIA-28, Financial Reporting System.

290"Conference Concludes European Coal Subsidies Will End," Power Europe (December 2, 1994).

291"Power to the People: Cracking Europe's Electric Cartels," The Wall Street Journal (December 22, 1995$),$ p. A5.

${ }^{292}$ OECD/IEA, Oil and Gas Supply Outlook, 1995.
} 
Interestingly, with the exception of South Africa, all of the aforementioned nation's coal industries have seen increasing levels of foreign direct investment from a handful of multinational conglomerates.

\section{Australia}

Until recently, the United States was the world's primary source of coal exports. In 1970, the United States accounted for one-half of the international coal trade. ${ }^{293}$ By 1994, the U.S. share of world coal trade had declined to 15 percent of the total. In 1986, Australia supplanted the United States as the world's largest exporter of coal. As recently as 1980, U.S. coal exports had been double those of Australia.

Coal is Australia's number one export. ${ }^{294}$ Some of the companies most prominent in the U.S. coal industry are also prominent in Australia's coal industry, particularly that part of the industry directed towards export markets. As in the United States, foreign investment plays a key role in Australia's coal industry, further indicating how multinational in character world coal investment has become. Australia consumes less than a third of domestic production (versus 90 percent in the United States).

Although 70 percent of Australia's coal exports goes to Japan, Japan's investment in Australian coal is comparatively small..$^{295}$ Ownership of Australian coal assets is largely held by Australian, U.S., and European companies. The largest producer of coal in Australia is the Australian multinational conglomerate, Broken Hill Proprietary Company Limited (BHP). In addition to its . Australian coal mining operations, BHP is the 17th largest coal producer in the United States, and also has coal mining interests in Indonesia. The second largest exporter of Australian coal is CRA Corp, an Australian company which has recently merged with the British company RTZ Corp. As noted earlier, RTZ Corp is the fourth largest producer of coal in the United States. Third among Australian coal producers is Cyprus Amax Minerals Company, a U.S. multinational minerals company and the second largest producer of coal in the United States. Other major exporters of Australian coal include Exxon, ARCO, and Peabody-all companies with major U.S. coal operations. The fifth largest exporter of Australian coal is Royal Dutch/Shell, which exited the U.S. coal-producing industry in 1994.

\section{South Africa}

South Africa is the third largest exporter of coal. Coal accounts for 98 percent of South African energy production and 78 percent of energy consumption. ${ }^{296}$ South Africa ranks seventh in coal reserves. ${ }^{297}$ For most of the last decade, United Nations' sanctions have restricted the flow of foreign direct investment to South African industries. Even in 1994, the year in which sanctions were lifted, foreign direct investment in South Africa was less than in $1980 .{ }^{298}$ Although they are primarily domestically-held corporations, South African coal mining companies are among the largest in the world. With the lifting of the U.N. sanctions in 1991, South Africa coal mining could become a target of foreign direct investment and a growing source of coal exports.

\section{China}

Coal is abundant and cheap in China. With the world's third largest deposits, China leads the world, both in the production and the consumption of coal. In 1994, coal accounted for 75 percent of the country's total energy consumption. The country's heavy reliance on its most available fuel is increasing as China's economic growth places greater demands on domestic petroleum supplies and the potential for petroleum import dependence increases. China's proximity to major coal-importing nations makes China an ideal exporter. Although rising, the amount of Chinese coal exports has been small due to domestic coal consumption requirements and poor infrastructure for exports. Coal imports by Asian countries are expanding primarily to meet rapidly increasing demand in electric power generation.

There has been some attempt at reform in the industry. Mine ownership has been partially redistributed from the government to private parties. Currently, around half of China's coal production comes from state-controlled mines and regional or local authorities.

\footnotetext{
${ }^{293}$ Suttill, Keith R., "Coal in Europe," Coal (March 1995), p. 20.

${ }^{294}$ Chadwick, John, "World Coal," Mining Magazine (September 1995), p. $146 \mathrm{ff}$.

${ }^{295}$ Coal Voice (June 1993), p. 1.

${ }^{296}$ Energy Information Administration, Country Energy Profiles, South Africa (Washington DC, August 1995), p. .

${ }^{207}$ Energy Information Administration, Country Energy Profiles, South Africa (Washington DC, August 1995), p. .

${ }^{298}$ The Economist (December 23, 1995 - January 5, 1996), p. 126.
} 
The other half is produced by collective or privately owned operations. ${ }^{299}$ Reforms also have extended to the removal of price controls in early $1994 .^{300}$

The industry is beginning, however, to attract foreign participation. For instance, cooperative agreement was announced between the government and an international consortium to construct a \$900-million underground coal slurry pipeline running from Shanxi Province to coastal Shandong. It will be the largest and longest such installation in the world and will have annual capacity of 15 million tons upon completion. Later, the project is to be expanded into an extensive coal slurry pipeline network. The project is one of the first major infrastructure projects in modern China to have western financial and management control. ${ }^{301}$ In addition, BHP Mineral \& Oil Company of Australia and two Chinese firms plan joint development of coalbed methane in North China's Shanxi province. ${ }^{302}$ Amoco and $A R C O$ are also exploring coal mining interests. ${ }^{303}$

\section{Colombia and Venezuela}

Another important area of recent international investment in coal lies in Latin America, primarily Colombia and Venezuela. Colombia is far and away the largest producer of coal in Latin America, followed by Brazil and Venezuela.$^{304}$ Colombia also has Latin America's largest coal reserves. Currently ranked ninth in the world in terms of coal exports, Colombia is expected to play an increasingly important role in world coal trade in the future. Again, several of the companies investing in Latin American coal mining are those with coal investments in the United States and Australia. The Italian energy company AGIP mines coal in Venezuela, as does Royal Dutch/Shell and the German energy conglomerate Ruhrkohl. AGIP and Veba also have coal mining operations in the United States. ${ }^{305}$ Both Exxon and Drummond have coal investments in Colombia. ${ }^{306}$

${ }^{299}$ Energy Information Administration, Country Analysis Briefs, (January 1996).

${ }^{300}$ Energy Information Administration, Country Analysis Briefs, (January 1996).

${ }^{301}$ Tse, Pui-Kwan, "China," Mining Annual Review (July 1995), p. 108ff.

302" China Seeks Foreign Help to Exploit Vast Coal Reserves," Asian Economic News (October 9, 1995).

${ }^{303}$ Amoco Corporation, Annual Report 1995, p: 15 and ARCO Coal Company, News Release (June 21, 1996).

${ }^{304}$ Although Brazil is the second largest producer of coal, it is a net importer, whereas almost all of Venezuela's coal production is directed towards export markets.

${ }^{305}$ Energy Information Administration, Energy Analysis Brief.

${ }^{306}$ Kendall, Sarita, "Survey of Colombia," Financial Times (October 9, 1995), p. III. 
Appendix

Worldwide

Privatization-Motivated

Energy Investment 



\section{Appendix}

\section{Worldwide Privatization-Motivated Energy Investment}

\section{Explanatory Notes}

The company-venture tables in this appendix (this matrix is also available electronically on a diskette in Lotus wk3 format and on the Internet FTP site at $\mathrm{ftp}: / /$ ftp.eia.doe.gov.) contains summary information for worldwide privatization-motivated energy investments by companies. The investment abbreviation conventions are provided at the end of these explanatory notes.

The focus of the appendix is on the companies making the investments, not the countries in which the investments are made. Readers who wish to focus on countries rather than on companies are assisted by separate groupings of the countries as follows: OECD countries, Latin American countries, socialist and formerly-socialist countries of eastern and central Europe, Asian countries, and African countries.

Companies with at least one energy investment or prospect in one of the countries within a group are listed across the top of the table; countries in the group with one or more recently privatized energy industry are listed along the left side of each table. The country of incorporation of each company is listed above the company name. Additional company-specific information, if known, is listed below the company name. This information includes: the primary SIC code of the company (if known), parent/subsidiary/affiliate companies (if any) also included in the appendix tables, and the latest annual report for the company if the company's annual report was used as a source of investment information.

The reader should note that lower case abbreviations indicate investment prospects and upper case abbreviations indicate actual investment commitments. Additionally, a few abbreviations are preceeded by a minus/negative sign, which indicates the sale of an investment asset or the abandonment of an investment prospect.

Although the key for the abbreviations employed in this appendix is provided, a review of two included companies may be instructive.

Example 1. ABB Energy Ventures, a Swedish/Swiss company has investments (owns equity) in gas-fired electricity generation (GFE) in two countries, Colombia and the United Kingdom. Additionally, ABB has a prospective petrochemical investment (pc) in Uzbekistan and a prospective geothermal investment (ge) in Pakistan.

Example 2. According to their 1995 annual report, AES Corporation, a U.S. electric services company (SIC code 4911), has a prospective investment in electricity generation fueled by coal, oil, and natural gas (cfp/ofp/gfe) and an actual investment in hydroelectric generation (HE) in Argentina. AES also has opened an office (OO) in Brazil. In the United Kingdom, AES has made investments in coal-fired, oil-fired, and gas-fired electricity generation (respectively, CFP, OFP, and GFE). AES has unspecified activities (*), which may be actual or prospective investments, in both Hungary and Poland. In China, AES has invested in hydroelectric power generation and in dual-fueled power generation [coal and oil (CFP/OFP)]. AES also has invested in coal-fired electricity generation in India and oil-fired generation in Pakistan, and is providing engineering services (NS) in Pakistan. Finally, AES has prospective power generation investments (pg) in Indonesia and Vietnam. 
Table A1. Matrix Abbreviations

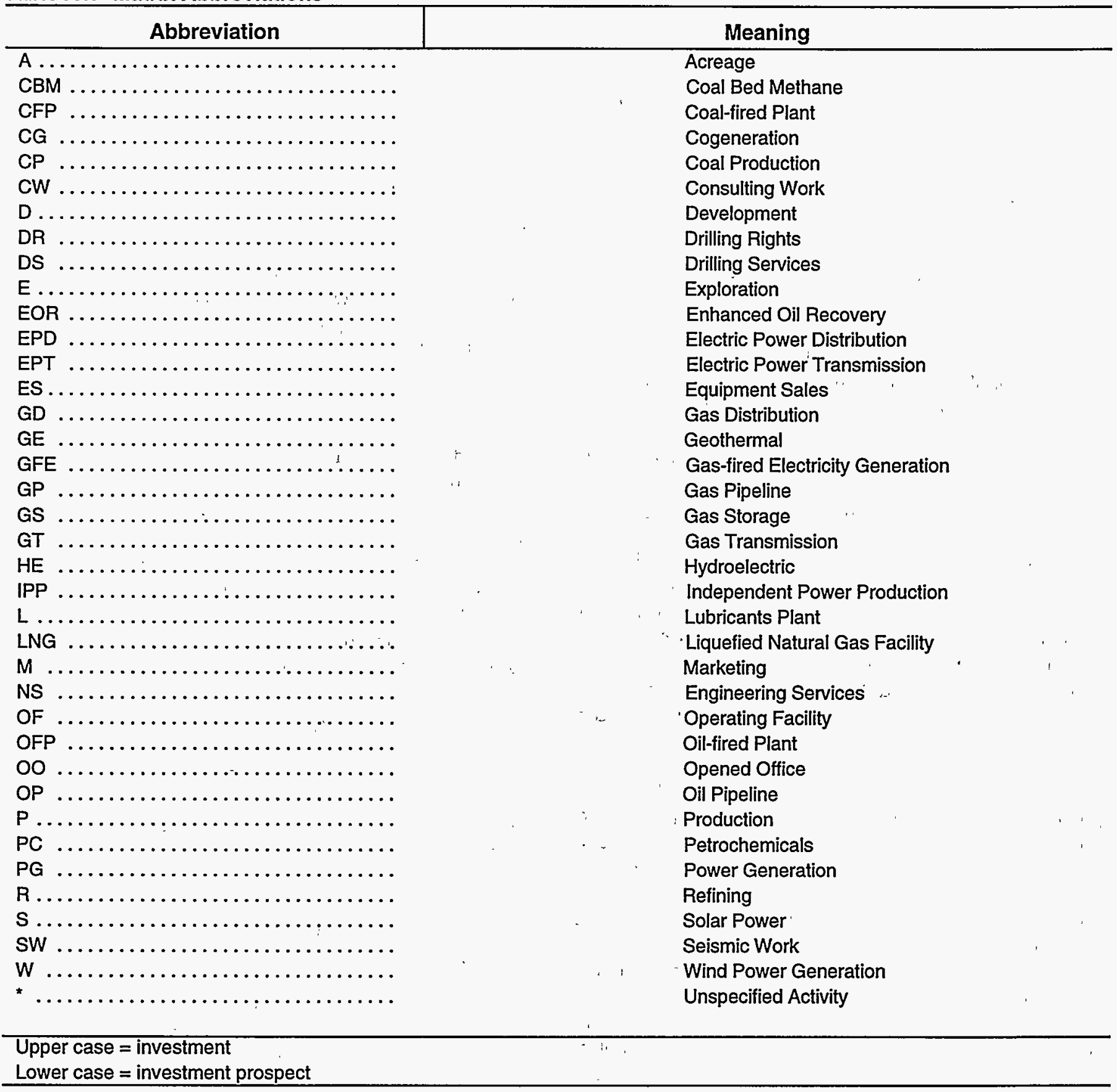


Table A2. Privatization-motivated Energy Investment in OECD.

\begin{tabular}{|c|c|c|c|c|c|c|c|c|c|c|}
\hline Country of Incorporation & $\begin{array}{l}\text { Sweden/ } \\
\text { Switzerland }\end{array}$ & U.S. & U.S. & U.S. & U.K. & Canada & U.S. & U.S. & U.S. & U.S. \\
\hline Company & $\begin{array}{c}\text { ABB Energy } \\
\text { Ventures }\end{array}$ & AES Corp & $\begin{array}{l}\text { Amerada } \\
\text { Hess }\end{array}$ & Amoco & $\begin{array}{c}\text { British } \\
\text { Petroleum } \\
\end{array}$ & $\begin{array}{c}\text { Canadian } \\
\text { Utilities, Ltd }\end{array}$ & $\begin{array}{c}\text { Central \& } \\
\text { South West } \\
\text { Corp } \\
\end{array}$ & Cinergy & Conoco & $\begin{array}{l}\text { Dominion } \\
\text { Resources }\end{array}$ \\
\hline $\begin{array}{l}\text { Primary Business of } \\
\text { Company (SIC Code) }\end{array}$ & 3823 & 4911 & 2911 & 2911 & 2911 & 4922 & 4922 & 4931 & 2911 & 4911 \\
\hline Parent/subsidiary & -- & -. & -- & - & - & - & -- & - & $\ldots$ & - \\
\hline Year of Annual Report & - & 1995 & - & 1995. & 1995 & - & $\ldots$ & 1995 & -- & 1995 \\
\hline \multicolumn{11}{|l|}{ Country } \\
\hline Australia $\ldots \ldots \ldots$ & -- & -- & -- & -- & GFE & -- & - & -- & -- & $A, j v-c b m$ \\
\hline New Zealand ........ & - & -- & -- & $-\cdot$ & -- & -- & - & - & -- & -- \\
\hline Portugal $\ldots \ldots \ldots \ldots$ & -- & -- & -- & -. & -- & -- & -- & $\cdots$ & -- & -- \\
\hline Spain ............ & - & -- & -- & - & - & -- & -- & -- & - & -- \\
\hline Sweden...$\ldots \ldots \ldots$ & -- & - & -- & -. & -. & - & -- & -- & -- & -- \\
\hline Turkey...$\ldots \ldots \ldots$ & -- & -- & - & - & - & -- & -- & -- & -- & - \\
\hline United Kingdom ....... & GFE,IPP & $\begin{array}{c}\text { CFP,OFP,GF } \\
\text { E,IPP }\end{array}$ & gd & $\mathrm{gd}$ & -- & GFE & $\begin{array}{c}\text { EPD,IPP,PG,g } \\
\text { d, GFE }\end{array}$ & EPD & gd & - \\
\hline
\end{tabular}

Table A2. Privatization-motivated Energy Investment in OECD (Continued).

\begin{tabular}{|c|c|c|c|c|c|c|c|c|c|c|}
\hline Country of Incorporation & U.S. & Finland & U.S. & Japan & U.S. & U.S. & U.S. & U.K. & U.S. & U.S. \\
\hline Company & Illinova Corp. & $\begin{array}{c}\text { Imatran } \\
\text { Voima (IVO) }\end{array}$ & $\begin{array}{c}\text { Kansas City } \\
\text { Power \& } \\
\text { Light }\end{array}$ & $\begin{array}{c}\text { Marubenl } \\
\text { Corp. }\end{array}$ & $\begin{array}{l}\text { Mission } \\
\text { Energy } \\
\text { Company }\end{array}$ & $\begin{array}{l}\text { Montana } \\
\text { Power Co. }\end{array}$ & $\begin{array}{l}\text { Morrison- } \\
\text { Knudsen }\end{array}$ & $\begin{array}{c}\text { National } \\
\text { Power PLC }\end{array}$ & $\begin{array}{l}\text { New York } \\
\text { State E\&G }\end{array}$ & $\begin{array}{c}\text { Nipsco } \\
\text { Industries } \\
\text { Inc. }\end{array}$ \\
\hline $\begin{array}{l}\text { Primary Business of } \\
\text { Company (SIC Code) }\end{array}$ & 4931 & $\ldots$ & 4911 & 5080 & 4911 & 4931 & .- & 4911 & 4931 & 4931 \\
\hline Parent/subsidiary & -- & - & - & $\begin{array}{l}\text { (parent of } \\
\text { Sithe) }\end{array}$ & $\begin{array}{c}\text { (subsidiary of } \\
\text { Edison } \\
\text { International) }\end{array}$ & - & - & $=$ & $=$ & $=$ \\
\hline Year of Annual Report & -- & - & - & 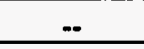 & 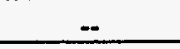 & 1995 & 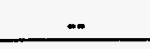 & 1995 & $\ldots$ & - \\
\hline \multicolumn{11}{|l|}{ Country } \\
\hline Australla $\ldots \ldots \ldots$ & -- & -- & - & GFE & GFE,CFP & -- & -- & - & -. & -- \\
\hline New Zealand...$\ldots$. & -- & - & $P G$ & - & -- & - & -- & -- & -- & - \\
\hline Portugal $\ldots \ldots \ldots \ldots$ & - & -- & - & - & -- & - & $P G$ & $P G$ & -. & -- \\
\hline Spain $\ldots \ldots \ldots \ldots$ & - & - & - & -- & HE & -- & -- & $P G$ & CW & - \\
\hline Sweden $\ldots . . . \ldots \ldots$ & - & $P G$ & -- & -- & -- & -- & -- & - & -- & -- \\
\hline Turkey $\ldots \ldots \ldots \ldots$ & -- & -- & -- & -- & $P G$ & -- & - & -- & -- & -- \\
\hline United Kingdom & $\mathrm{CG}$ & GFE,IPP & $P G$ & -- & GFE,IPP & GFE/CG & -- & -- & -- & pg \\
\hline
\end{tabular}


Table A2. Privatization-motivated Energy Investment in OECD (Continued).

\begin{tabular}{|c|c|c|c|c|c|c|c|c|c|c|}
\hline Country of Incorporation & Norway & U.S & U.S. & Canada & U.S. & U.S. & U.S. & Malaysia & U.S. & U.K. \\
\hline Company & Norsk Hydro & $\begin{array}{c}\text { Northeast } \\
\text { Utilities }\end{array}$ & $\begin{array}{c}\text { Northern } \\
\text { States Power } \\
\end{array}$ & Nova Corp & NRG Energy & Pacific G\&E & Pacificorp & Petronas & $\begin{array}{c}\text { Phillips } \\
\text { Petroleum }\end{array}$ & $\begin{array}{c}\text { PowerGen } \\
\text { PLC } \\
\end{array}$ \\
\hline $\begin{array}{l}\text { Primary Business of } \\
\text { Company (SIC Code) }\end{array}$ & 2870 & 4911 & 4931 & 4922 & 4931 & 4931 & 4911 & -. & 2911 & 4911 \\
\hline Parentsubsidiary & - & - & $\begin{array}{c}\text { (parent of } \\
\text { NRG Energy) }\end{array}$ & - & $\begin{array}{c}\text { (subsidlary of } \\
\text { Northern } \\
\text { States Power) }\end{array}$ & $=$ & - & - & - & - \\
\hline Year of Annual Report & 1994 & -. & $1995 \cdots$ & $=$ & - & $\ldots$ & - & - & -- & 1995 \\
\hline \multicolumn{11}{|l|}{ Country } \\
\hline Australia $\ldots \ldots \ldots \ldots$ & - & -- & CFP & jv-GP & CFP,EPT & EPT - & PG,EPD & jV-GT & -- & $P G$ \\
\hline New Zealand...$\ldots \ldots$ & - & -- & $\mathrm{pg}$ & & $\mathrm{pg}$ & -- & -- & -- & -- & $P G$ \\
\hline Portugal ............. & - & -- & - & -- & -- & -. & -- & -- & -- & GFE \\
\hline Spain..$\ldots \ldots \ldots \ldots$ & -- & -- & -- & -- & -- & -- & -- & -- & -- & -- \\
\hline Sweden $\ldots \ldots \ldots \ldots$ & - & -- & -. & -- & -- & -. & - & -- & -- & -- \\
\hline Turkey $\ldots \ldots \ldots$ & - & -- & -. & -- & -- & -- & -- & $\because$ & -. & -- \\
\hline United Kingdom ........ & gd & $\mathrm{Pg}, \mathrm{CG}$ & -- & - & $\ddot{-}$ & IPP & - & - & gd & - \\
\hline
\end{tabular}

Table A2. Privatization-motivated Energy Investment in OECD (Continued).

\begin{tabular}{|c|c|c|c|c|c|c|c|c|c|c|}
\hline Country of Incorporation & U.S. & Germany & U.S. & U.S. & U.S. & Norway & Norway & U.S. & U.S. & U.S. \\
\hline Company & SCECorp & Siemens & $\begin{array}{c}\text { Sithe } \\
\text { Energies }\end{array}$ & $\begin{array}{l}\text { Southern } \\
\text { Company }\end{array}$ & \begin{tabular}{|c|} 
Southern \\
Electric \\
International \\
\end{tabular} & $\begin{array}{l}\text { Statkraft } \\
\text { SF }\end{array}$ & $\begin{array}{c}\text { Statoil Norge } \\
\text { A.S. }\end{array}$ & $\begin{array}{c}\text { System } \\
\text { Energy } \\
\text { Resources }\end{array}$ & Tenneco Inc. & Texaco Inc. \\
\hline $\begin{array}{l}\text { Primary Business of } \\
\text { Company (SIC Code) }\end{array}$ & 4911 & 3661 & 4911 & 4911 & 4911 & 4911 & 5541 & 4911 & 3523 & 1311 \\
\hline Parentsubsidiary & $\ldots$ & $\ldots$ & $\begin{array}{c}\text { (subsidiary of } \\
\text { Marubeni) }\end{array}$ & $\begin{array}{c}\text { (parent of } \\
\text { Southem Electric } \\
\text { International) }\end{array}$ & $\begin{array}{l}\text { (subsidiary of } \\
\text { Southern Co.) }\end{array}$ & - & $=$ & $\begin{array}{l}\text { (affiliate of } \\
\text { Entergy) }\end{array}$ & $\ldots$ & -- \\
\hline Year of Annual Report & - & - & - & 1995 & .. & - & 1995 & .. & $\ldots$ & 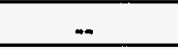 \\
\hline \multicolumn{11}{|l|}{ Country } \\
\hline \multicolumn{3}{|c|}{ Australia $\ldots \ldots \ldots \ldots$ IPP/CG,GFE,EPT } & GFE/PP, CG & -- & -- & -- & -- & $P G$ & gp & -- \\
\hline New Zealand...$\ldots \ldots$ & - & -- & -- & - & -- & -- & -- & -- & -. & -- \\
\hline Portugal & -- & gfo & -- & -- & -- & -- & -- & -- & -- & .- \\
\hline Spain & IPP,HE & -- & -- & -- & -- & -- & -- & .- & .- & .- \\
\hline Sweden $\ldots . .$. & - & -- & - & - & .- & PG & -- & .- & .- & .- \\
\hline Turkey $\ldots \ldots \ldots \ldots$ & $P G$ & -- & -- & ns & -.- & -- & - & -- & -- & $\therefore$ \\
\hline United Kingdom . ...... & IPP & - & $=$ & OO,GFE,EPD,gd & GFE & - & gd & - & -. & $\mathrm{gd}{ }^{\circ}$ \\
\hline
\end{tabular}


Table A2. Privatization-motivated Energy Investment in OECD (Continued).

\begin{tabular}{|c|c|c|c|c|c|c|}
\hline Country of Incorporation & U.S. & Japan & France & U.S. & U.S. & U.S. \\
\hline Company & Texas Utilities Company & Tomen Corp. & TOTAL & Utilicorp United & West Coast Energy & $\begin{array}{c}\text { Western } \\
\text { Resources }\end{array}$ \\
\hline $\begin{array}{l}\text { Primary Business of } \\
\text { Company (SIC Code) }\end{array}$ & 4911 & - & 1311 & 4932 & - & 4911 \\
\hline Parent/subsidiary & - & - & - & - & - & -- \\
\hline Year of Annual Report & 1995 & - & 1995 & 1995 & -- & $\ldots$ \\
\hline \multicolumn{7}{|l|}{ Country } \\
\hline Australia $\ldots \ldots \ldots$ & EPD & -- & -- & jV-PG,jV-EPD & $P G$ & - \\
\hline New Zealand ......... & -- & - & -- & EPD & - & -- \\
\hline Portugal $\ldots \ldots \ldots \ldots$ & - & - & -- & -- & - & -- \\
\hline Spain $\ldots \ldots \ldots \ldots \ldots$ & $=-$ & - & -- & -- & -- & -. \\
\hline Sweden...$\ldots \ldots \ldots$ & -- & -- & -- & -- & -- & -- \\
\hline Turkey $\ldots \ldots \ldots \ldots \ldots$ & -- & -- & $\mathrm{pg}$ & - & -- & $P G$ \\
\hline United Kingdom ....... & -. & GFE,IPP & $\mathrm{gd}$ & pg,epd,GD,gd & -- & .. \\
\hline
\end{tabular}

Sources: Various company annual reports; The Mead Corporation, Lexis-Nexis, and Disclosure Incorporated, Compact Disclosure and Worldscope Disclosure. 
Table A3. Privatization-motivated Energy Investment in Latin America.

\begin{tabular}{|c|c|c|c|c|c|c|c|c|c|c|}
\hline Country of Incorporation & $\begin{array}{c}\text { Sweden/ } \\
\text { Switzerland }\end{array}$ & U.S. & Canada & U.S. & U.S. & U.S. & Australla & U.S. & U.S. & Argentina \\
\hline Company & $\begin{array}{c}\text { ABB Energy } \\
\text { Ventures }\end{array}$ & AES Corp & $\begin{array}{c}\text { Alberta } \\
\text { Energy Corp }\end{array}$ & $\begin{array}{c}\text { American } \\
\begin{array}{c}\text { Electric Power } \\
\text { Co }\end{array} \\
\end{array}$ & $\begin{array}{c}\text { American } \\
\text { International } \\
\text { Petrol Corp } \\
\end{array}$ & Amoco & $\begin{array}{c}\text { Ampolex } \\
\text { Ltd. }\end{array}$ & $\begin{array}{c}\text { Anderman- } \\
\text { Smith }\end{array}$ & $\begin{array}{c}\text { Anschutz } \\
\text { Overseas } \\
\text { Corp. }\end{array}$ & $\begin{array}{c}\text { Apex } \\
\text { Petroleum } \\
\text { Inc. }\end{array}$ \\
\hline $\begin{array}{l}\text { Primary Business of } \\
\text { Company (SIC Code) }\end{array}$ & - & 4911 & 1311 & 4911 & 1311 & 2911 & 1311 & -- & - & -- \\
\hline Parent/subsidiany & -- & - & $\begin{array}{c}\text { (parent of } \\
\text { Chieftain } \\
\text { Energy } \\
\text { Resources) } \\
\end{array}$ & - & - & $\ldots$ & - & $\ldots$ & -- & -- \\
\hline Year of Annual'Report & - & 1995 & 1995 & 1995 & -- & 1995 & - & - & -. & - \\
\hline \multicolumn{11}{|l|}{ Country } \\
\hline Argentina $\ldots \ldots \ldots \ldots$ & -- & c/ofp/gfe,HE & $E, P, g p$ & -- & -- & $A, E, P, P G, p c$ & $P$ & -- & -- & -- \\
\hline Bolivia .............. & -- & -- & -- & -- & -- & -- & - & -- & -- & -- \\
\hline Brazil...$\ldots \ldots \ldots$ & -- & 00 & - & -- & -- & -- & - & -- & -- & -- \\
\hline Chile...$\ldots \ldots \ldots \ldots$ & -- & -- & -- & -- & -- & -- & - & - & -- & -- \\
\hline Colombla ........... & GFE & - & - & -- & $\mathbf{P}$ & $A, E, D, P, g p$ & - & - & -- & -- \\
\hline Costa Rica ........... & - & -- & -- & -- & -- & -- & -- & -- & -- & -- \\
\hline Dominican Republic .... & - & -- & -- & -- & -- & -- & -- & - & -- & -- \\
\hline Ecuador...$\ldots \ldots \ldots$ & - & -- & -- & -- & -- & $A, E, j v-P$ & -- & - & -- & -- \\
\hline El Salvador ........... & - & -- & -- & -- & -- & -- & -- & - & -- & -- \\
\hline Guatemala...$\ldots \ldots$ & - & - & -- & -- & -- & -- & - & - & -- & -- \\
\hline Honduras...$\ldots \ldots \ldots$ & - & -- & -- & -- & -. & -- & -- & - & -- & -- \\
\hline Mexiço...$\ldots \ldots \ldots$ & - & -- & - & $\cdots$ & -- & $\mathrm{m}, \mathrm{gp}$ & -- & - & -- & $\therefore$ \\
\hline Nicaragua ............ & - & -- & -- & - & -- & -- & -- & - & -- & -- \\
\hline Panama ........... & -- & -- & -- & - & -- & -- & -- & - & -- & $\therefore$ \\
\hline Paraguay $\ldots \ldots \ldots \ldots$ & -- & -- & -- & -- & $\cdots$ & -- & -- & -- & A & -- \\
\hline Peru........... & - & -- & -- & -- & $A, j \vee-E, P$ & a & -- & -- & -- & -- \\
\hline Trinidad ............. & - & - & -- &.- & -- & E,D,P,EOR,Ing,GFE & -- & A & -- & $A$ \\
\hline Uruguay $\ldots \ldots \ldots \ldots$ & -- & - & -- & $-\cdot$ & -- & -- & - & - & -- & -- \\
\hline Venezuela $\ldots \ldots \ldots \ldots$ & -- & - & -- & $\mathrm{CW}$ & -- & $A, a, E, p$ & - & - & - & -- \\
\hline
\end{tabular}


Table A3. Privatization-motivated Energy Investment in Latin America (continued).

Table A3. Privatization-molivated Energy livestment in Latin America (continued).

\begin{tabular}{|c|c|c|c|c|c|c|c|c|c|c|}
\hline Country of Incorporation & U.S. & U.S. & U.S. & U.S. & U.S. & U.S. & France & U.S. & U.S. & U.S. \\
\hline Company & $\begin{array}{c}\text { Arcadian } \\
\text { Corp }\end{array}$ & ARCO & $\begin{array}{c}\text { Argosy } \\
\text { Energy } \\
\text { International }\end{array}$ & $\begin{array}{c}\text { Aspen } \\
\text { Exploration } \\
\text { Corp }\end{array}$ & $\begin{array}{c}\text { Aviva } \\
\text { Petroleum } \\
\text { Corp }\end{array}$ & $\begin{array}{c}\text { Baltimore } \\
\text { G\&E }\end{array}$ & $\begin{array}{c}\text { Basic } \\
\text { Petroleum } \\
\text { International }\end{array}$ & $\begin{array}{c}\text { Basic } \\
\text { Resources } \\
\text { International, } \\
\text { Ltd }\end{array}$ & $\begin{array}{c}\text { Bechtel } \\
\text { Enterprises } \\
\text { Inc. }\end{array}$ & $\begin{array}{c}\begin{array}{c}\text { Benton Oil \& } \\
\text { Gas Co. }\end{array} \\
\end{array}$ \\
\hline $\begin{array}{l}\text { Primary Business of } \\
\text { Company (SIC Code) }\end{array}$ & 2873 & 1311 & - & 1311 & 1311 & 4911 & 2911 & 6799 & - & 1311 \\
\hline Parent/subsidiany & -- & -- & $\begin{array}{c}\text { (affiliate of } \\
\text { Gamet } \\
\text { Resources) }\end{array}$ & 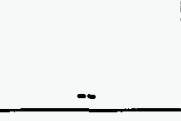 & $\begin{array}{l}\text { (affiliate of } \\
\text { Gamet } \\
\text { Resources) }\end{array}$ & - & -- & $\begin{array}{r}\text { (subsidiary of } \\
\text { Texas Utilities) } \\
\end{array}$ & - & $\because$ \\
\hline Year of Annual Report & $\cdots$ & 1995 & - & - & -- & - & -- & -- & -- & - \\
\hline \multicolumn{11}{|l|}{ Country } \\
\hline Argentina...$\ldots \ldots \ldots$ & -- & -- & -- & $\cdots$ & $\cdots$ & -- & -- & -- & -- & -- \\
\hline Bolivia .............. & -- & - & - & - & -- & $P G$ & - & -- & - & -- \\
\hline Brazil $\ldots . . \ldots \ldots \ldots$ & - & $-M$ & - & -- & -- & -- & - & -- & -- & -- \\
\hline Chile...$\ldots \ldots \ldots \ldots$ & - & -- & $-\cdots$ & -- & -- & $-\cdots$ & -- & -- & - & -- \\
\hline Colombia...$\ldots \ldots \ldots$ & - & -- & $\theta$ & -- & $A, E, P$ & - & -- & -- & - & -- \\
\hline Costa Rica ............ & -- & -- & -- & -- & -- & - & -- & -- & -- & -- \\
\hline Dominican Republic ..... & - & -- & -- & - & -- & - & -- & -- & - & -- \\
\hline Ecuador...$\ldots \ldots \ldots$ & -- & $E, D$ & -- & -- & -- & -- & -- & $\cdots$ & - & -- \\
\hline El Salvador ............ & -- & -- & -- & - & -- & -- & $-\cdot$ & -- & -- & -- \\
\hline Guatemala...$\ldots \ldots \ldots$ & -- & -- & -- & -- & -- & -- & $\mathbf{E}$ & $o p, R$ & - & -- \\
\hline Honduras ............ & -- & - & -- & -- & - & -- & -- & -- & - & -- \\
\hline Mexico...$\ldots \ldots \ldots$ & -- & - & -- & $E$ & - & -- & -- & - & jv-gfe & - \\
\hline Nicaragua...$\ldots \ldots \ldots$ & -- & - & -- & - & - & -- & - & - & -- & -- \\
\hline Panama.......... & -- & $\cdots$ & -- & -- & $\cdots$ & -- & -- & $\cdots$ & -- & -- \\
\hline Paraguay $\ldots \ldots \ldots \ldots$ & - & - & - & - & - & -- & $\cdots$ & - & -- & -- \\
\hline Peru $\ldots \ldots \ldots \ldots \ldots$ & $\cdots$ & A & - & - & -- & - & - & -- & -- & - \\
\hline Trinidad............... & $\mathrm{pc}$ & $A, \theta$ & -- & - & -- & - & -- & -- & -- & -- \\
\hline Uruguay...$\ldots \ldots \ldots$ & -- & -- & -- & - & -- & -- & -- & -- & -- & -- \\
\hline Venezuela...$\ldots \ldots \ldots$ & -- & $P, E O R, r$ &.- & -- & -- & - & -- & -. & -- & $A, P$ \\
\hline
\end{tabular}


Table A3. Privatization-motivated Energy Investment in Latin America (continued).

\begin{tabular}{|c|c|c|c|c|c|c|c|c|c|}
\hline Country of Incorporation & U.S. & Canada & British V.I. & Australia & U.K. & U.K. & Australla & U.S. & U.S. \\
\hline Company & $\begin{array}{l}\text { Besicorp } \\
\text { Group Inc. }\end{array}$ & $\begin{array}{c}\text { Bolivlan Power } \\
\text { Group }\end{array}$ & Bridas Corp & $\begin{array}{l}\text { Bridge Oil } \\
\text { USA, Inc }\end{array}$ & British Gas & $\begin{array}{c}\text { British } \\
\text { Petroleum }\end{array}$ & $\begin{array}{l}\text { Broken Hill } \\
\text { Proprietary } \\
\text { Company }\end{array}$ & $\begin{array}{c}\text { Cabot Oll \& } \\
\text { Gas Co. }\end{array}$ & Calpine Corp. \\
\hline $\begin{array}{l}\text { Primary Business of } \\
\text { Company (SIC Code) }\end{array}$ & 3433 & 4911 & 1311 & 5170 & 4923 & 2911 & 1311 & 4923 & 4931 \\
\hline Parent/subsidiary & - & -- & -- & - & -- & $=$ & - & -. & -. \\
\hline Year of Annual Report & 1995 & 1995 & 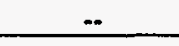 & - & 1995 & 1995 & - & 1995 & - \\
\hline \multicolumn{10}{|l|}{ Country } \\
\hline Argentina $\ldots \ldots \ldots \ldots$ & -- & pg & $P$ & $E$ & e,PG,GP & -- & E,P,pg,gp & -- & -- \\
\hline Bolivia $\ldots \ldots \ldots \ldots \ldots \ldots$ & -- & PG & -- & -- & $\mathrm{GP}, \mathrm{A}, \mathrm{a}$ & -- & $E, P$ & -- & -- \\
\hline Brazil $\ldots \ldots \ldots \ldots \ldots$ & -- & $\mathrm{pg}$ & -. & -- & gfe,gp & -- & gfe,gp & -- & -- \\
\hline Chile $\ldots \ldots, \ldots \ldots \ldots$ & -- & -- & -- & - & gfe,gp,GP & $E, P, g f e$ & E & -- & -- \\
\hline Colombia $\ldots \ldots \ldots \ldots$ & -- & - & -- & -- & $\mathrm{gp}$ & $E, P, o p, g p$ & $E, P$ & $\mathrm{pc}$ & -- \\
\hline Costa Rica $\ldots \ldots \ldots \ldots$ & -- & -- & -- & -- & -. & -- & -- & -- & -- \\
\hline Dominican Republic .... & -- & -- & -- & -. & -- & -. & -- & -- & .- \\
\hline Ecuador $\ldots \ldots \ldots \ldots \ldots$ & -- & -- & -- & -- & -- & -- & .- & -- & -- \\
\hline El Salvador ............ & -- & - & -- &.- & -- & -- & - & -- & -- \\
\hline Guatemala $\ldots \ldots \ldots \ldots$ & -- & - & -- & -- & -- & -- & -- & -- & -- \\
\hline Honduras $\ldots \ldots \ldots \ldots$ & -- & -- & - & - & -- & -. & -- & - & -- \\
\hline Mexico $\ldots \ldots \ldots \ldots \ldots$ & $\infty$ & -- & -- & -- & -- & -- & E & -- & ge \\
\hline Nicaragua $\ldots \ldots \ldots \ldots$ & -- & -- & -- & - & -- & -. & -- & -- & -. \\
\hline Panama $\ldots \ldots \ldots \ldots$ & -- & -- & -- & - & -- & -- & -- & -- & -- \\
\hline Paraguay $\ldots \ldots \ldots \ldots \ldots$ & -- & -- & -- & -- & $\cdots$ & -- & -- & -- & -- \\
\hline Peru $\ldots \ldots \ldots \ldots \ldots$ & -- & $\mathrm{pg}$ & -- & -- & -- & -- & -- & -- & -- \\
\hline Trinidad...$\ldots \ldots \ldots \ldots$ & -- & - & -- & - & $D, P, M$, Ing & -- & E & Ing & -- \\
\hline Unuguay ........ & -- & -- & -- & - & -- & -- & -- & -- & -- \\
\hline Venezuela & .. & -- & -- & - & - & $A, E, P, E O R, O P$ & $E, D$ & -- & .- \\
\hline
\end{tabular}


Table A3. Privatization-motivated Energy Investment in Latin America (continued).

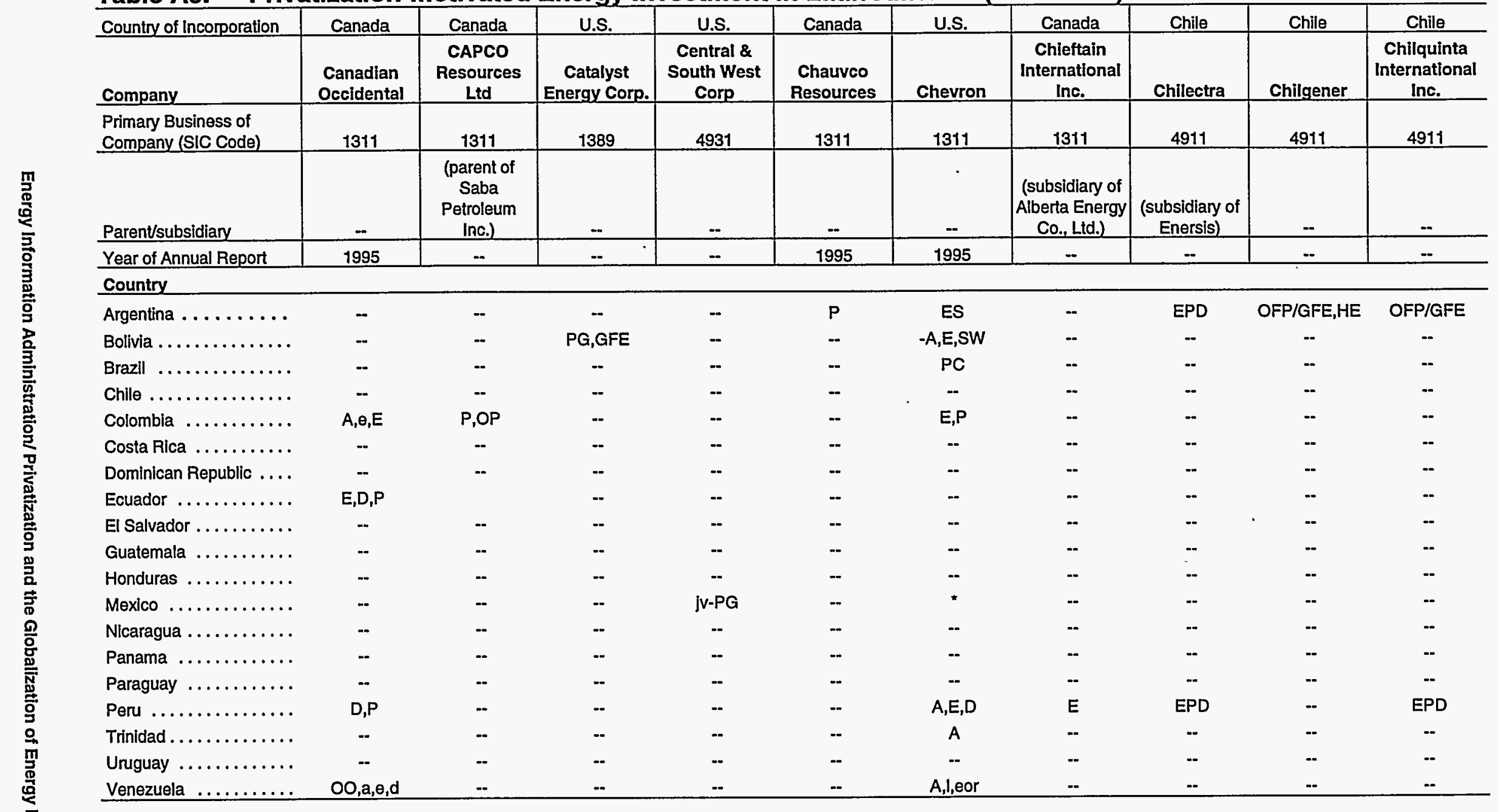


Table A3. Privatization-motivated Energy Investment in Latin America (continued).

\begin{tabular}{|c|c|c|c|c|c|c|c|c|c|c|}
\hline Country of Incorporation & U.S. & U.S. & U.S. & U.S. & U.S. & U.S. & U.S. & U.S. & U.S. & U.S. \\
\hline Company & Cinergy & $\begin{array}{c}\text { Clticorp } \\
\text { Capital } \\
\text { Investors }\end{array}$ & $\begin{array}{c}\text { Clitizens } \\
\text { Power \& } \\
\text { Light } \\
\end{array}$ & $\begin{array}{c}\text { Clayton } \\
\text { Williams } \\
\text { Energy } \\
\end{array}$ & CMS Energy & Coastal & Cogenerex & $\begin{array}{l}\text { Cogentrix } \\
\text { Energy Inc. }\end{array}$ & $\begin{array}{c}\text { Community } \\
\text { Energy } \\
\text { Alternatives }\end{array}$ & Conoco \\
\hline $\begin{array}{l}\text { Primary Business of } \\
\text { Company (SIC Code) }\end{array}$ & 4931 & - & - & 1311 & 4931 & 2911 & 4911 & - & 4911 & 2911 \\
\hline Parent/subsidiary & - & - & - & -- & $\begin{array}{l}\text { (parent of } \\
\text { Nomeco Oll } \\
\text { and Gas) }\end{array}$ & $\ldots$ & $\ldots$ & $\ldots$ & $\begin{array}{c}\text { (subsidiary of } \\
\text { Public Service } \\
\begin{array}{c}\text { Enterprise } \\
\text { Group) }\end{array} \\
\end{array}$ & $\begin{array}{c}\text { (subsidiary of } \\
\text { du Pont) }\end{array}$ \\
\hline Year of Annual Report & 1995 & -- & -. & - & 1995 & 1995 & .. & -- & .. & -- \\
\hline \multicolumn{11}{|l|}{ Country } \\
\hline Argentina $\ldots \ldots \ldots$ & $\begin{array}{c}-P G, E P D, P G, \\
G P\end{array}$ & GFE,EPD & -- & $-E, g p$ & $\begin{array}{c}\text { GT,HE,OFP/G } \\
\mathrm{FE}\end{array}$ & $P, m$ & -- & -. & -- & -- \\
\hline Bolivia ............ & -- & - & -- & -- & - & -- & $P G$ & $P G$ & -- & -- \\
\hline Brazil $\ldots \ldots \ldots \ldots \ldots$ & -- & -- & -- & -- & -. & -- & .- & -- & -- & -- \\
\hline Chile $\ldots \ldots \ldots \ldots \ldots$ & GP & -- & -- & $\mathrm{gp}$ & $\mathrm{gp}$ & -. & .- & -- & -. & -- \\
\hline Colombia $\ldots \ldots \ldots \ldots$ & A & -- & CFP & -. & $\mathbf{P}$ & -. & -- & -- & -. & -- \\
\hline Costa Rica $\ldots \ldots \ldots \ldots$ & -- & -- & -- & -- & -- & -- & -- & -- & -- & -- \\
\hline Dominican Republic ... & -- & -- & -- & -- & -- & OFP & .- & -. & -. & -- \\
\hline Ecuador $\ldots \ldots \ldots \ldots$ & A & -- & -- & -- & $D, P, G P$ & & -- & -- & -. & -- \\
\hline El Salvador...$\ldots \ldots$. & -- & -- & -- & -- & - & gfe,OFP & -. & -- & -- & -- \\
\hline Guatemala $\ldots \ldots \ldots$. & -- & -- & -- & -- & - & ofp & -. & -- & -- & -- \\
\hline Honduras $\ldots \ldots \ldots \ldots$ & -- & -- & -- & -- & - & -- & -- & -. & .- & -- \\
\hline Mexico $\ldots \ldots \ldots \ldots \ldots$ & -- & - & -- & -. & $\mathbf{P}$ & -- & -- & -. & -- & $\infty, d$ \\
\hline Nicaragua $\ldots \ldots \ldots \ldots$ & -- & -- & -- & -. & -- & -. & -- & -- & -- & -- \\
\hline Panama $\ldots \ldots \ldots \ldots$ & -- & -- & -- & -. &.- & $\because$ & -- & -- & -- & -- \\
\hline Paraguay $\ldots \ldots \ldots \ldots$ & -- & -- & -- & -- & -- & -- & -- & -- & -- & -- \\
\hline Peru $\ldots \ldots \ldots \ldots \ldots$ & -- & -- & $\ldots$ & a & -- & $\mathrm{E}$ & -. & $\therefore$ & $\therefore-$ & $\therefore$ \\
\hline Trinidad $\ldots \ldots \ldots, \ldots, \ldots$ & - & - & -- & -- & -- & -- & -- & -- & -. & -- \\
\hline Uruguay...$\ldots \ldots \ldots$ & GP & - & -- & -- & GS & -. & -- & -- & -. & - \\
\hline Venezuela. & A & -- & -- & A & A,eor & -- & -. & -- & $P G$ & $\begin{array}{l}\text { A,jv-p,r,m;jv-or } \\
\text { imulsion }\end{array}$ \\
\hline
\end{tabular}


Table A3. Privatization-motivated Energy Investment in Latin America (continued).

\begin{tabular}{|c|c|c|c|c|c|c|c|c|c|c|}
\hline Country of Incorporation & U.S. & U.S. & Australla & U.S. & France & U.S. & German & U.S. & U.S. & U.S. \\
\hline Company & $\begin{array}{c}\text { Consolidated } \\
\text { Hydro }\end{array}$ & $\begin{array}{c}\text { Constellation } \\
\text { Energy }\end{array}$ & $\begin{array}{c}\text { Coplex } \\
\text { Resources }\end{array}$ & $\begin{array}{l}\text { Cordex } \\
\text { Petroleum } \\
\text { Inc. }\end{array}$ & Corexland & CPC & Deminex & $\begin{array}{l}\text { Destec } \\
\text { Energy }\end{array}$ & $\begin{array}{c}\text { Dl Industries } \\
\text { Inc. }\end{array}$ & $\begin{array}{l}\text { Diamond } \\
\text { Shamrock }\end{array}$ \\
\hline $\begin{array}{l}\text { Primary Business of } \\
\text { Company (SIC Code) }\end{array}$ & 4911 & - & $=$ & - & - & $=$ & - & 8711 & 1381 & 2911 \\
\hline Parent/subsidiary & - & $\begin{array}{c}\text { (subsidiary of } \\
\text { BG\&E and } \\
\text { Potomac } \\
\text { Electric Power } \\
\text { Co.) } \\
\end{array}$ & $=$ & - & 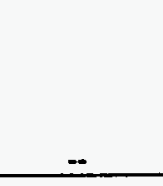 & - & $\begin{array}{c}\text { (afililate of } \\
\text { Wintershall) }\end{array}$ & $\because$ & $=$ & - \\
\hline Year of Annual Report & $=$ & - & - & - & $=$ & - & 1994 & $=$ & - & $=$ \\
\hline \multicolumn{11}{|l|}{ Country } \\
\hline Argentina ......... & PG & - & - & $E$ & - & -. & $E, P$ & -- & $E, D$ & -- \\
\hline Bolivia .............. & -- & PG & -- & - & - & - & -- & -- & -- & $P$ \\
\hline Brazil $\ldots \ldots, \ldots \ldots \ldots$ & -- & -- & -- & - & - & - & -- & -- & -- & -. \\
\hline Chille $\ldots \ldots \ldots \ldots \ldots$ & -- & -- & -- & - & -- & -- & -- & - & -- & -- \\
\hline Colombia $\ldots \ldots \ldots \ldots$ & -- & -- & A & -- & -- & A & -- & -- & -. & -. \\
\hline Costa Rica $\ldots \ldots \ldots \ldots$ & -. & -- & -- & -- & -- & -- & -- & -- & -- & -- \\
\hline Dominican Republic .... & -- & -- & -- & -- & -- & -- & -- & OFP & -- & -- \\
\hline Ecuador $\ldots \ldots \ldots \ldots \ldots$ & -. & -- & $\cdots$ & -- & -- & $P$ & -- & -- & -- & -- \\
\hline El Salvador ............ & -. & -- & - & -- & -- & -- & - & - & -- & ge \\
\hline Guatemala $\ldots \ldots \ldots \ldots$ & -- & -- & -- & -- & -- & -- & -- & -- & -- & -- \\
\hline Honduras $\ldots \ldots \ldots \ldots$. & $\cdots$ & -- & -- & -- & -- & -- & - & - & -- & -- \\
\hline Mexico $\ldots \ldots \ldots \ldots \ldots$ & -- & -- & -- & -- & -- & -- & - & $\mathrm{pg}$ & $E, D, G E$ & -- \\
\hline Nicaragua........... & -- & -- & -- & $\because$ & -- & -- & - & -. & -- & -- \\
\hline Panama $\ldots \ldots \ldots \ldots$ & -- & -- & -- & $\because$ & $\cdots$ & -- & -- & -- & -- & -- \\
\hline Paraguay $\ldots \ldots \ldots \ldots$ & -- & -. & -- & $\because$ & -- & -- & -- & -- & -- & -- \\
\hline Peru ................. & -- & -- & -- & -- & -- & -- & -- & -- & -- & -- \\
\hline Trinidad .............. & -- & -- & -- & -- & -- & -- & A & -- & -- & -- \\
\hline Unuguay $\ldots \ldots \ldots \ldots$ & -- & -- & -- & -. & -- & -- & -- & -- & -- & - \\
\hline Venezuela $\ldots \ldots \ldots \ldots$ & -- & $=$ & - & - & $\mathbf{P}$ & - & - & $\ddot{-}$ & $\theta, d$ & - \\
\hline
\end{tabular}


Table A3. Privatization-motivated Energy Investment in Latin America (continued).

.

\begin{tabular}{|c|c|c|c|c|c|c|c|c|c|c|}
\hline Country of Incorporation & U.S. & U.S. & U.K. & U.S. & U.S. & France & France & U.S. & Chile & Chille \\
\hline Company & Digicon Inc. & $\begin{array}{c}\text { Dominion } \\
\text { Resources } \\
\end{array}$ & Drummond & Duke Power & $\begin{array}{l}\text { E.I. du Pont } \\
\text { de Nemours }\end{array}$ & $\begin{array}{l}\text { Electricite de } \\
\text { France (EdF) }\end{array}$ & Elf Aquilaine & $\begin{array}{c}\text { El Paso } \\
\text { Natural Gas } \\
\end{array}$ & $\begin{array}{c}\text { Empressa } \\
\text { Nacional del } \\
\text { Petroleo } \\
\text { (ENAP) } \\
\end{array}$ & Endesa \\
\hline $\begin{array}{l}\text { Primary Business of } \\
\text { Company (SIC Code) }\end{array}$ & 1382 & 4911 & $-\cdots$ & 4911 & 2911 & 4911 & 2911 & 4922 & -- & -. \\
\hline Parent/subsidiary & -. & - & $\ldots$ & $\ldots$ & -. & - & .. & - & .. & -. \\
\hline Year of Annual Report & $\ldots$ & 1995 & $\ldots$ & 1995 & $\ldots$ & .. & 1995 & 1995 & .- & .- \\
\hline \multicolumn{11}{|l|}{ Country } \\
\hline Argentina $\ldots \ldots \ldots \ldots$ & $D, P$ & GFE & -. & epd, GFE,HE & * & HE,EPD,EPT & -n & $\therefore$ & $\mathbf{P}$ & EPD \\
\hline Bolivia ................. & $\mathrm{E}$ & HE & -- & $\mathrm{pg}$ & -- & - & $A, E, P$ & -- & -- & -- \\
\hline Brazil $\ldots \ldots \ldots \ldots \ldots$ & -- & -- & -- & -- & * & -- & -. & - & -- & -. \\
\hline Chile $\ldots \ldots \ldots \ldots \ldots \ldots$ & -. & - & -- & GFE & -. & -- & - & -- & $P$ & -- \\
\hline Colombia $\ldots \ldots \ldots \ldots$ & -- & - & $\mathrm{CP}$ & - & $:$ & -- & -- & -- & $E$ & - \\
\hline Costa Rica ........... & $\because$ & - & -- & -- & $\because$ & - & -- & -- & -- & -- \\
\hline Dominican Republic ...... & -- & -- & -- & -- & $\cdots$ & - & -- & -- & -- & -- \\
\hline Ecuador $\ldots \ldots \ldots \ldots \ldots$ & - & -- & - & -- & - & -- & $E, P$ & -- & $P$ & -- \\
\hline El Salvador $\ldots \ldots \ldots \ldots$ & - & -. & -- & -- & - & -- & -- & -- & .- & .- \\
\hline Guatemala $\ldots \ldots \ldots \ldots$ & - & -- & -- & -- & -- & $\therefore$ & -- & - & -- & -- \\
\hline Honduras...$\ldots \ldots \ldots$ & -. & -- & -- & -- & $\because$ & - & -- & -- & -- & -. \\
\hline Mexico $\ldots \ldots \ldots \ldots \ldots$ & -- & -- & -- & - & * & - & -- & $j v-g f e, g p$ & -- & -- \\
\hline Nicaragua ............. & -- & $\therefore$ & - & -- & $\because$ & -- & -- & - & -- & -. \\
\hline Panampa...$\ldots \ldots \ldots$ & -- & -- & -- & $\because$ & -- & - & -- & - & -- & $\because$ \\
\hline Paraguay...$\ldots \ldots \ldots$ & -- & - & $\because$ & - & -- & -- & $\because$ & - & -- & - \\
\hline$\ldots \ldots, \ldots \ldots \ldots$ & -- & - & -- & - & 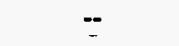 & $=$ & $A, \theta$ & A,gfe & -. & HE,EPD \\
\hline Trinidad ............... & $\because$ & -- & -- & -- & * & -- & $\theta$ & $\cdots$ & $\because-$ & -- \\
\hline Unuguay,............... & $\because$ & -- & -- & -- & -- & - & - & $=-$ & $\because$ & -- \\
\hline Venèzuela ${ }^{\prime} . \ldots \ldots \ldots$ & - & - & - & - & $\star$ & - & $E$ & -. & A & -- \\
\hline
\end{tabular}


Table A3. Privatization-motivated Energy Investment in Latin America (continued).

\begin{tabular}{|c|c|c|c|c|c|c|c|c|c|c|}
\hline Country of Incorporation & U.S. & U.S. & Chile & U.S. & U.S. & U.S. & Italy & U.S. & U.K. & U.S. \\
\hline Company & $\begin{array}{c}\text { Energy } \\
\text { Equipment } \\
\text { Resources } \\
\end{array}$ & $\begin{array}{c}\begin{array}{c}\text { Energy } \\
\text { Initiative } \\
\text { Inc. }\end{array} \\
\end{array}$ & Enersis S.A. & $\begin{array}{l}\text { Enova } \\
\text { Corp. }\end{array}$ & Enron & $\begin{array}{c}\text { Enserch } \\
\text { Corp. }\end{array}$ & \begin{tabular}{|c|} 
Ente \\
$\begin{array}{c}\text { Nazionale } \\
\text { Idrocarburl } \\
\text { (ENI) }\end{array}$ \\
\end{tabular} & Entergy Corp. & $\begin{array}{c}\text { Enterprise } \\
\text { Oil }\end{array}$ & $\begin{array}{c}\text { Enterra } \\
\text { Corp. }\end{array}$ \\
\hline $\begin{array}{l}\text { Primary Business of } \\
\text { Company (SIC Code) }\end{array}$ & - & - & 4911 & 4911 & 1321 & 4922 & 2911 & 4911 & 1311 & 7359 \\
\hline Parent/subsidiary & -. & $\begin{array}{c}\text { (IPP } \\
\text { subsidiary } \\
\text { of General } \\
\text { Public } \\
\text { Utilities) } \\
\end{array}$ & - & - & - & -- & $\begin{array}{c}\text { (parent of } \\
\text { AGIP) }\end{array}$ & - & -- & -- \\
\hline Year of Annual Report & $\ddot{-}$ & - & - & - & 1995 & 1995 & 1994 & 1995 & 1995 & - \\
\hline \multicolumn{11}{|l|}{ Country } \\
\hline Argentina & - & - & GFE,PG,EPD & -- & GT,GFE & -- & A & GFE/OFP,EPT,EPD,-gp & -. & $\mathrm{CW}$ \\
\hline Bolivia .............. & -- & $P G$ & -- & - & $\mathrm{gp}, \mathrm{pg}$ & -- & -- & PG & - & - \\
\hline Brazil $\ldots \ldots \ldots \ldots \ldots$ & DS & -- & -- & - & $\mathrm{gp}$ & -- & $\cdots$ & $\mathrm{pg}$ & - & -- \\
\hline Chile ............... & - & -- & -- & -. & - & -- &.- & PG & -- & -- \\
\hline Colombia $\ldots \ldots \ldots \ldots$ & -- & -- & -- & -. & GP,gt,-gp,cg, ofp & -- & -- & - & - & cW \\
\hline Costa Rica $\ldots \ldots \ldots \ldots$ & -- & -- & -- & -. & -- & -- & -. & - & -. & -- \\
\hline Dominican Republic .... & -- & PG & -- & -. & $P G$ & -- & -- & -- & -- & -- \\
\hline Ecuador.......$\ldots$. & - & -- & -- & - & -- & -- & A & - & - & -- \\
\hline El Salvador ........... & - & -- & -- & - & -- & -- & -. & - & - & -. \\
\hline Guatemala..$\ldots \ldots \ldots$ & -- & -. & -- & - & OFP & -- & -- & -- & - & -- \\
\hline Honduras $\ldots \ldots \ldots \ldots$ & -- & -- & -- & - & -- & -- & -- & -- & -- & -- \\
\hline Mexico $\ldots \ldots \ldots \ldots \ldots$ & - & -- & -- & $\mathrm{gp}$ & -- & jv-gp\&gfe & -- & -- & - & $\mathrm{cw}$ \\
\hline Nicaragua $\ldots \ldots \ldots \ldots$ & -- & -. & -- & .. & -. & -- & -. & -. & -. & -. \\
\hline Panama ...... & -- & .. & -- & -. & .- & -- & -- & -- & -- & -- \\
\hline Paraguay $\ldots \ldots \ldots \ldots$ & .- & .- & -- & -- & $\cdots$ & -. & -. & -- & -- & -- \\
\hline Peru ................ & $\cdots$ & -. & $P G, E P D$ & -. & -. & - & .- & HE,ofp & $O O, a, A, E$ & -- \\
\hline Trinidad ............. & .. & -- & - & - & $A, P$ & - & A & -. & -- & -- \\
\hline Uruguay $\ldots \ldots \ldots \ldots$ & -- & -- & -- & -- & -- & - & -- & -- & -- & -- \\
\hline Venezuela ... & .. & .. & .- & .- & A,pc & $\ldots$ & $\mathrm{CP}$ & .. & -. & - \\
\hline
\end{tabular}


Table A3. Privatization-motivated Energy Investment in Latin America (continued).

\begin{tabular}{|c|c|c|c|c|c|c|c|c|c|c|}
\hline Country of Incorporation & U.S. & U.S. & U.S. & Australla & U.S. & U.K. & U.S. & France & U.S. & U.S. \\
\hline Company & $\begin{array}{c}\text { Equitable } \\
\text { Resources, } \\
\text { Inc. }\end{array}$ & Exxon & $\begin{array}{l}\text { Falcon } \\
\text { Drilling }\end{array}$ & $\begin{array}{c}\text { First } \\
\text { Australian } \\
\text { Resources } \\
\end{array}$ & Fluor Daniel & $\begin{array}{c}\text { Foster } \\
\text { Wheeler } \\
\text { Corp. }\end{array}$ & $\begin{array}{c}\text { Garnet } \\
\text { Resources }\end{array}$ & $\begin{array}{c}\text { Gaz de } \\
\text { France (GDF) }\end{array}$ & $\begin{array}{l}\text { General } \\
\text { Electric } \\
\end{array}$ & $\begin{array}{c}\text { General } \\
\text { Publlc } \\
\text { Utilities } \\
\end{array}$ \\
\hline $\begin{array}{l}\text { Primary Business of } \\
\text { Company (SIC Code) }\end{array}$ & 4923 & 2911 & 1381 & - & 8711 & 2911 & 1311 & 4923 & 3641 & 4911 \\
\hline Parent/subsidiany & -. & - & .. & -- & -. & -- & $\begin{array}{c}\text { (parent of } \\
\text { Argosy Energy } \\
\text { and Aviva } \\
\text { Petroleum) } \\
\end{array}$ & -- & .. & - \\
\hline Year of Annual Report & - & 1995 & -- & $\ldots$ & -- & -- & - & $\ldots$ & -- & - \\
\hline \multicolumn{11}{|l|}{ Country } \\
\hline Argentina $\ldots \ldots \ldots \ldots$ & -- & $A, R, M$ & - & $E$ & - & -- & - & -- & -- & - \\
\hline Bolivia ................ & -- & E & - & - & - & -- & -- & $\mathrm{cW}$ & -- & PG \\
\hline Brazil $\ldots \ldots \ldots \ldots \ldots$ & -- & -- & -- & -- & -- & $\infty$ & - & - & -- & -- \\
\hline Chile $\ldots \ldots \ldots \ldots \ldots \ldots$ & -- & -- & -- & -- & -- & $\mathrm{pc}$ & -- & -- & gfe & -- \\
\hline Colombia $\ldots \ldots \ldots \ldots$ & $A, \theta$ & $A, E, P,-P,-o p, C P$ & -- & -- & $\mathrm{gp}$ & -- & $A, \theta, d, p, o p$ & -- & -- & GFE \\
\hline Costa Rica $\ldots \ldots \ldots \ldots$ & -- & -- & -. & -- & -- & -- & -- & -- & -- & -- \\
\hline Dominican Republic ..... & -. & -- & -- & -. & -. & - & - & -- & -- & $P G$ \\
\hline Ecuador $\ldots \ldots \ldots \ldots$ & -- & -- & -- & -- & -- & -- & - & - & -- & -- \\
\hline El Salvador ............. & -- & -- & - & -- & -- & -- & -- & -- & -. & -- \\
\hline Guatemala $\ldots \ldots \ldots \ldots$ & -- & - & - & -- & -- & -- & - & -- & -- & -- \\
\hline Honduras $\ldots \ldots \ldots \ldots$. & -- & -- & -- & -- & $\because$ & -- & -- & -- & -- & -. \\
\hline Mexico $\ldots . . . \ldots \ldots \ldots$ & - & -- & $\mathrm{cW}$ & -- & gfe & -- & -- & -- & jv-gie & -- \\
\hline Nicaragua .............. & -- & $\mathrm{R}$ & -- & -- & -- & -- & -- & -- & -- & - \\
\hline Panama $\ldots \ldots \ldots \ldots \ldots$ & -- & -- & -- & -. & -. & -- & -- & -- & -. & - \\
\hline Paraguay $\ldots \ldots \ldots \ldots$ & -- & - & -- & -- & -- & -- & - & -- & -. & - \\
\hline Peru $\ldots \ldots \ldots \ldots \ldots$ & -- & A & -. & -- & $\cdots$ & $\because$ & -- & -- & -- & -- \\
\hline Trinidad ............... & -- & $\mathrm{E}$ & - & -- & -. & -- & . & -- & -- & -- \\
\hline Unuguay...$\ldots \ldots \ldots \ldots$ & - & -- & -- & -- & -- & -- & - & gp,gs & -- & -- \\
\hline Venezuela & - & $e, E, d, p$, Ing & -- & -- & - & pc & -- & -. & .. & -- \\
\hline
\end{tabular}


Table A3. Privatization-motivated Energy Investment in Latin America (continued).

\begin{tabular}{|c|c|c|c|c|c|c|c|c|c|c|}
\hline Country of Incorporation & U.S. & U.S. & Canada & U.S. & Honduras & U.S. & U.S. & Spain & U.S. & Japan \\
\hline Company & $\begin{array}{c}\text { Global } \\
\text { Natural } \\
\text { Resources }\end{array}$ & $\begin{array}{c}\text { Harken } \\
\text { Energy Corp } \\
\end{array}$ & $\begin{array}{c}\text { Home Oil } \\
\text { Co., Ltd }\end{array}$ & $\begin{array}{l}\text { Hondo Oil } \\
\text { and Gas } \\
\text { Company }\end{array}$ & $\begin{array}{l}\text { Honduras } \\
\text { Electric } \\
\text { Company }\end{array}$ & $\begin{array}{c}\text { Houston Industries } \\
\text { Inc. }\end{array}$ & $\begin{array}{c}\text { Houston } \\
\text { Light \& } \\
\text { Power } \\
\end{array}$ & Iberdrola & Illinova Corp. & Itochu Corp. \\
\hline $\begin{array}{l}\text { Primary Business of } \\
\text { Company (SIC Code) }\end{array}$ & 1311 & 1311 & 1311 & 2911 & - & 4911 & 4911 & 4911 & 4911 & 5050 \\
\hline Parent/subsidiary & - & $\ldots$ & - & $\ldots$ & - & - & $\ldots$ & - & - & $\ldots$ \\
\hline Year of Annual Report & - & - & -- & - & - & 1995 & - & -- & -- & $\because$ \\
\hline \multicolumn{11}{|l|}{ Country } \\
\hline Argentina $\ldots \ldots \ldots \ldots$ & $P$ & - & $D$ & $D$ & $\ldots$ & CG,GFE,EPD,EPT & $P G$ & $P G$ & -- & PC \\
\hline Bolivia ............. & - & -- & - & -- & - & -- & -- & EPD & -- & - \\
\hline Brazil...$\ldots \ldots \ldots \ldots$ & - & -- & - & - & -- & -- & - & -- & -- & - \\
\hline Chile .............. & - & -- & -- & -- & -- & -- & - & -- & -- & - \\
\hline Colombia .......... & - & $A,-A, \Theta, E$ & -- & $E, D, g p$ & - & -- & -- & -- & -- & -- \\
\hline Costa Rica .......... & - & -- & -- & - & - & -- & - & -- & -- & - \\
\hline Dominican Republic .... & -- & -- & -- & $m$ & OFP & -- & - & -- & - & -- \\
\hline Ecuador...$\ldots \ldots \ldots$ & -- & -- & -- & - & -- & -- & - & -- & -- & - \\
\hline El Salvador ........... & -- & -- & -- & - & -- & -- & - & -- & -- & - \\
\hline Guatemala .......... & -- & -- & -- & - & -- & -- & - & -- & -- & -- \\
\hline Honduras ........... & -- & -- & -- & -- & - & -- & -- & -- & $P G$ & - \\
\hline Mexico......... & -- & - & -- & - & - & -- & - & -- & -- & -- \\
\hline Nicaragua ........... & -- & -- & -- & - & - & -- & -- & -- & - & - \\
\hline Panama...$\ldots \ldots \ldots$ & -- & - & -- & -- & - & -- & - & -- & -- & - \\
\hline Paraguay....$\ldots \ldots$ & -- & - & -- & - & - & -- & -- & -- & -- & -- \\
\hline Perú...$\ldots \ldots \ldots \ldots$ & -- & -- & - & -- & -- & -- & -- & -- & $A$ & - \\
\hline Trinldad............. & -- & - & - & -- & -- & -- & -- & -- & -- & - \\
\hline Uruguay ............ & -- & -- & - & - & - & -- & -- & -- & -- & - \\
\hline Venezuela ... & - & -- & -- & $\ldots$ & - & - & - & -- & - & - \\
\hline
\end{tabular}


Table A3. Privatization-motivated Energy Investment in Latin America (continued).

\begin{tabular}{|c|c|c|c|c|c|c|c|c|c|c|}
\hline Country of Incorporation & U.S. & Kuwait & U.K. & U.S. & U.S. & U.S. & U.S. & U.S. & U.S. & U.S. \\
\hline Company & $\begin{array}{c}\text { K\&M } \\
\text { Engineering } \\
\text { \& Consulting } \\
\end{array}$ & $\begin{array}{c}\text { Kuwait } \\
\text { Petroleum } \\
\text { Corp. }\end{array}$ & Lasmo & $\begin{array}{c}\text { Latin } \\
\text { American } \\
\text { Cogen, Inc. }\end{array}$ & $\begin{array}{l}\text { Louisiana } \\
\text { Land \& } \\
\text { Exploration }\end{array}$ & $\begin{array}{c}\text { LG\&E Energy } \\
\text { Corp }\end{array}$ & $\begin{array}{c}\text { Marathon Oil } \\
\text { Co. } \\
\end{array}$ & $\begin{array}{c}\text { Maxus } \\
\text { Energy Corp. }\end{array}$ & $\begin{array}{l}\text { MidAmerican } \\
\text { Plpeline }\end{array}$ & MidCon Gas \\
\hline $\begin{array}{l}\text { Primary Business of } \\
\text { Company (SIC Code) }\end{array}$ & .- & -- & 1311 & - & 1311 & 4911 & 1311 & 1311 & -- & -- \\
\hline Parent/subsidiary & -- & -- & -- & - & - & - & $\begin{array}{c}\text { (subsidiary of } \\
\text { USX) }\end{array}$ & $\begin{array}{c}\text { (subsidiary of } \\
\text { YPF) }\end{array}$ &.- & $\begin{array}{l}\text { (subsidiary of } \\
\text { Occidental) }\end{array}$ \\
\hline Year of Annual Report & -- & -- & -- & -- & 1995 &.- & -- & $\ldots$ & $\ldots$ & -- \\
\hline \multicolumn{11}{|l|}{ Country } \\
\hline Argentina $\ldots \ldots \ldots \ldots$ & -- & -- & -- & -- & -. & GFE & $s$ & - & -- & -- \\
\hline Bolivia ............... & -- & -- & - & -- & -- & -- & -- & $E, P$ & - & -- \\
\hline Brazil...$\ldots \ldots \ldots$ &.- & - & - & -- & -- & .- & -- & - & -- & -- \\
\hline Chile .............. & -- & -- & - & -- & -- & -- & -- & -- & $\therefore$ & -- \\
\hline Colombia ........... & GFE & -- & $A, e, P$ & $\mathrm{cg}$ & $D, P$ & -- & -- & $-A, P$ & $\because$ & -- \\
\hline Costa Rica .......... & -- & - & - & -- & -- & -- & -- & -- & -- & -- \\
\hline Dominican Republic .... & -- & -- & - & -- & -- & -- & -- & -- & - & -- \\
\hline Ecuador...$\ldots \ldots \ldots$ & - & $P$ & - & -- & -- & -- & - & $P$ & -- & -- \\
\hline El Salvador ............ & -- & - & - & -- & -- & -- & -- & -- & -- & -- \\
\hline Guatemala .......... & -- & $\therefore$ & - & - & -- & -- & -- & -- & -. & -- \\
\hline Honduras ............ & -- & -- & - & -- & -- & -- & -- & -- & -.' & -- \\
\hline Mexico ............. & -- & - & -- & - & -- & -- & -- & -- & gp & gp \\
\hline Nicaragua...$\ldots \ldots$. & $\cdots$ & -- & -- & -- & -- & -- & -- & -- & -- & -- \\
\hline Panama......... & - & -- & -- & -- & -- & -- & -- & -- & -- & -- \\
\hline Paraguay...$\ldots \ldots$. & - & -- & -- & -- & -- & -- & -- & -- & -- & -- \\
\hline Peru ............... & - & -- & -- & - & -- & -- & -- & -- & -- & -- \\
\hline Trinidad .............. & -- & -- & -. & -- & -- & -- & -- & -- & .- & -- \\
\hline Uruguay...$\ldots \ldots \ldots$ & -- & - & -- & -- & -- & -- & -- & - & -- & -- \\
\hline Venezuela $\ldots . . . \ldots$. & -- & - & - & -- & A,sw & -- & - & $A, E, P$ & -. & -- \\
\hline
\end{tabular}


Table A3. Privatization-motivated Energy Investment in Latin America (continued).

\begin{tabular}{|c|c|c|c|c|c|c|c|c|c|c|}
\hline Country of Incorporation & Japan & Japan & U.S. & U.K. & U.S. & Chile & U.S. & U.S. & Japan & U.S. \\
\hline Company & Mitsubishl & Mitsul \& Co. & Mobil & $\begin{array}{c}\text { Monument } \\
\text { Oil }\end{array}$ & $\begin{array}{c}\text { Murphy Oil } \\
\text { Co. }\end{array}$ & $\begin{array}{c}\text { National } \\
\text { Electric of } \\
\text { Chile }\end{array}$ & $\begin{array}{l}\text { Navajo } \\
\text { Pipeline }\end{array}$ & $\begin{array}{c}\text { New World } \\
\text { Power }\end{array}$ & Nippon Oil & $\begin{array}{c}\begin{array}{c}\text { Nomeco Oil \& } \\
\text { Gas }\end{array} \\
\end{array}$ \\
\hline $\begin{array}{l}\text { Primary Business of } \\
\text { Company (SIC Code) }\end{array}$ & 5050 & 6221 & 1311 & 1311 & 2911 & 4911 & 4922 & 4911 & 2911 & 1311 \\
\hline Parent/subsidiary & $=$ & - & - & $=$ & - & $=$ & $\begin{array}{c}\text { (subsidiary of } \\
\text { Holly Corp) }\end{array}$ & - & - & $\begin{array}{c}\text { (affiliate of } \\
\text { CMS Energy) }\end{array}$ \\
\hline Year of Annual Report & - & - & 1995 & - & - & - & - & - & - & - \\
\hline \multicolumn{11}{|l|}{ Country } \\
\hline Argentina $\ldots . . . \ldots \ldots$ & -. & -- & $P, M$ & E & - & $P G$ & - & PG & -- & -- \\
\hline Bolivia ............... & - & -- & $a, E$ & $\cdots$ & - & $g p$ & -- & $\cdots$ & -. & -- \\
\hline Brazil $. . . \ldots \ldots \ldots . . . .$. & $\cdots$ & -- & -- & -- & - & $\mathrm{pg}$ & - & $O O, P G$ & -• & -- \\
\hline Chile...$\ldots \ldots \ldots \ldots$ & -- & gfe & M & -- & -- & - & $\cdots$ & - & $\cdots$ & -- \\
\hline Colombia...$\ldots \ldots \ldots$ & -- & -- & $M$ & - & - & $\mathrm{pg}$ & - & - & $\cdots$ & $\mathbf{P}$ \\
\hline Costa Rica ........... & $\cdots$ & - & - & - & - & -- & - & - & $\cdots$ & -- \\
\hline Dominican Republic ..... & - & - & $\theta, E$ & - & -- & -- & -- & - & $\cdots$ & -- \\
\hline Ecuador ............. & -- & - & SW,jv-P,M & -- & $P$ & pg & - & -- & A & -- \\
\hline El Salvador ............ & - & -- & -- & - & -- & -- & -- & -- & - & -- \\
\hline Guatemala...$\ldots \ldots$ & - & - & - & - & -- & -- & $\cdots$ & -- & - & -. \\
\hline Honduras $\ldots \ldots \ldots \ldots$ & -- & - & $\therefore$ & - & -- & -- & $\cdots$ & - & - & -- \\
\hline Mexico........... & -- & - & $M, I$ & - & -- & -- & gp & PG & - & -- \\
\hline Nicaragua $\ldots \ldots \ldots \ldots$ & -- & $-\infty$ & -- & - & -- & -- & -- & - & -- & -- \\
\hline Panama......... & -- & $\cdots$ & $\cdots$ & - & -- & -- & - & - & -- & -- \\
\hline Paraguay $\ldots \ldots \ldots \ldots$ & -- & - & - & - & -- & -- & -- & - & - & -- \\
\hline Peru $\ldots . . . \ldots \ldots \ldots$ & -- & $\cdots$ & $a, E, J-D, M$ & - & A & pg & -- & - & - & -- \\
\hline Trinidad.............. & -- & - & $-\cdots$ & - & -- & -- & - & - & - & -- \\
\hline Uruguay...$\ldots \ldots \ldots$ & - & $-\cdot$ & -- & -- & -- & -- & -- & - & - & -- \\
\hline Venezuela ............ & Ing &.- & $A, E, r, M, L$ & -- & -- & $\mathrm{pg}$ & -. & -- & $A, E$ & $p$ \\
\hline
\end{tabular}


Table A3. Privatization-motivated Energy Investment in Latin America (continued).

\begin{tabular}{|c|c|c|c|c|c|c|c|c|c|}
\hline Country of Incorporation & U.S. & U.S & U.S. & Canada & U.S. & U.S. & Canada & U.S. & U.S. \\
\hline Company & NorAm Energy & $\begin{array}{c}\begin{array}{c}\text { Northeast } \\
\text { Utilities }\end{array} \\
\end{array}$ & $\begin{array}{c}\text { Northern } \\
\text { States Power }\end{array}$ & Nova Corp & NRG Energy & Occidental & $\begin{array}{l}\text { Occidental } \\
\text { Chemicals }\end{array}$ & $\begin{array}{c}\text { Ogden } \\
\text { Products }\end{array}$ & $\begin{array}{c}\text { Olympic Oll \& } \\
\text { Gas }\end{array}$ \\
\hline $\begin{array}{l}\text { Primary Business of } \\
\text { Company (SIC Code) }\end{array}$ & 4923 & 4911 & 4931 & 3081 & 4931 & 2812 & - & 4953 & - \\
\hline Parent/subsidiary & - & - & $\begin{array}{c}\text { (parent of NRG } \\
\text { Energy) }\end{array}$ & $=$ & $\begin{array}{c}\text { (subsidiary of } \\
\text { Northem States } \\
\text { Power) }\end{array}$ & $\begin{array}{c}\text { (parent of } \\
\text { MildCon Gas) }\end{array}$ & -- & $=$ & - \\
\hline Year of Annual Report & 1995 & - & 1995 & -. & - & 1995 & .. & $\ldots$ & $\ldots$ \\
\hline
\end{tabular}

Country

Argentina $\ldots \ldots \ldots \ldots \ldots$

Bolivia ....

Brazil

Chile

-- $\quad$ GFE,PG,CG

Colombla

Costa Rica .............

Dominican Republic

Ecuador

El Salvador

Guatemala

Honduras

Mexico .

Nicaragua

Panama

Paráguay

Peru ....

Trinidad.

Uruguay

Venezuela

\begin{tabular}{cc}
-- & GFE,PG,CG \\
-- & -- \\
-- & -- \\
- & -- \\
gP & -- \\
-- & $W$ \\
-- & -- \\
-- & -- \\
- & -- \\
-- & -- \\
-- & -- \\
gp & - \\
- & - \\
-- & -- \\
- & - \\
-- & -- \\
-- & -- \\
-- & -- \\
-- & -- \\
\hline
\end{tabular}

-.

--

PG

$\therefore$. 
Table A3. Privatization-motivated Energy Investment in Latin America (continued).

\begin{tabular}{|c|c|c|c|c|c|c|c|c|c|}
\hline Country of Incorporation & Canada & U.S. & U.S. & U.S. & U.S. & U.S. & U.S. & Brazil & U.S. \\
\hline Company & Ontario Hydro & $\begin{array}{c}\text { Opon } \\
\text { Development } \\
\text { Corp. } \\
\end{array}$ & $\begin{array}{c}\text { Oryx Energy } \\
\text { Co. }\end{array}$ & $\begin{array}{c}\text { Pacific } \\
\text { Enterprises }\end{array}$ & Pacific G\&E & $\begin{array}{c}\text { Parker \& } \\
\text { Parsley }\end{array}$ & Pennzoil & Petrobras & $\begin{array}{l}\text { Phillips } \\
\text { Petroleum }\end{array}$ \\
\hline $\begin{array}{l}\text { Primary Business of } \\
\text { Company (SIC Code) }\end{array}$ & 4911 & - & 1311 & 4923 & 4931 & 1311 & 2911 & 1311 & 2911 \\
\hline Parent/subsidiary & - & $\ldots$ & $\ldots$ & 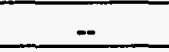 & - & - & - & $\ldots$ & - \\
\hline Year of Annual Report & - & - & 1995 & $\ldots$ & - & - & - & 1994 & -- \\
\hline \multicolumn{10}{|l|}{ Country } \\
\hline Argentina ............ & -- & - & $\ldots$ & $\mathrm{gd}$ & - & $E$ & $j v-M$ & $G P, E, D, P$ & -- \\
\hline Bollvia .............. & - & -- & -- & -- & - & -- & - & GP & -- \\
\hline Brazil...$\ldots \ldots \ldots$ & -- & -- & -- &.- & -- & -- & -- & -- & -- \\
\hline Chile .............. & -- & - & $\therefore$ & -- & GP & $\cdots$ & - & - &.- \\
\hline Colombia .......... & -- & $g p, E, D$ & -. & -- & -- & -- & $-\infty$ & $E, D, P$ & -- \\
\hline Costa Rica .......... & -- & -- & -- & - & -- & -- & - & - & -- \\
\hline Dominican Republic .... & -- & -- & -- & -- & - & -- & - & - & -- \\
\hline Ecuador...$\ldots \ldots \ldots$ & -- & -- & $a, A, P$ & - & -- & - & -. & $E, D, P$ & -- \\
\hline El Salvador ........... & -- & -- & - & -- & -- & - & - & -- & -- \\
\hline Guatemala .......... & -- & -- & -- & - & -- & -- & - & $\cdots$ & -- \\
\hline Honduras $\ldots \ldots \ldots \ldots$ & - & -- & - & -- & -- & -- & -- & - & -- \\
\hline Mexico $\ldots . . \ldots \ldots$. & -- & -- & -- & jv-gd & gp,jv-gfe & -- & -- &.- & -- \\
\hline Nicaragua ........... & - & -- & - & - & -- & -- & -- & -- & -- \\
\hline Panama ........... & - & -- & -- & -- & -- & -- & -- & -- & -- \\
\hline Paraguay $\ldots \ldots \ldots \ldots$ & - & -- & - & - & -- & -- & -- & - & A \\
\hline Peru ${ }^{*} . \ldots \ldots \ldots \ldots$ & EPD & -- & -- & -- & -- & -- & $L$ & - & - \\
\hline Trinidad..$\ldots \ldots \ldots \ldots$ & - & -- & -- & -- & -- & -- & - & - & -- \\
\hline Uruguay $\ldots \ldots \ldots \ldots$ & - & -- & -- & -- & -- & -- & -- & -- & $\therefore$ \\
\hline Venezuela........ & -- & - & - & - & -- & $\ldots$ & $\mathrm{a}, \mathrm{A}, \mathrm{r}, \mathrm{pc}$ & $-\cdots$ & -- \\
\hline
\end{tabular}


Table A3. Privatization-motivated Energy Investment in Latin America (continued).

D.

\begin{tabular}{|c|c|c|c|c|c|c|c|c|c|c|}
\hline Country of Incorporation & Argentina & U.S. & U.K. & U.S. & U.S. & U.S. & U.S. & Canada & Spain & $\begin{array}{c}\text { The Netherlands } \\
\text { N.K.K. }\end{array}$ \\
\hline Company & Pluspetrol & $\begin{array}{c}\text { PP\&L } \\
\text { Resources }\end{array}$ & $\begin{array}{c}\text { Premier oll } \\
\text { PLC } \\
\end{array}$ & $\begin{array}{c}\text { Pride } \\
\text { Petroleum } \\
\end{array}$ & PSI Resources & $\begin{array}{c}\text { Publlc } \\
\text { Service } \\
\text { Enterprise } \\
\text { Group } \\
\end{array}$ & $\begin{array}{c}\text { Quintana } \\
\text { Minerals Corp }\end{array}$ & Ranger Oil & Repsol & Royal Dutch/Shell \\
\hline $\begin{array}{l}\text { Primary Business of } \\
\text { Company (SIC Code) }\end{array}$ & - & 4911 & 1311 & 1389 & 4911 & 4931 & - & 1311 & 1311 & 1311 \\
\hline Parent/subsidlary & $\ldots$ & $\ldots$ & $\ldots$ & $\because$ & -- & 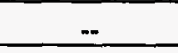 & -- & $\because$ & $\approx$ & (parent of Shell Oil) \\
\hline Year of Annual Report & - & - & 1995 & 1995 & - & - & - & 1995 & - & 1995 \\
\hline \multicolumn{11}{|l|}{ Country } \\
\hline Argentina & - & -- & - & DS & GFE/OFP, EPD,ns & -- & $P$ & -- & $E, P, R, O P$ & $E, P,-P, R, M, P C$ \\
\hline Bolivia ................ & - & $P G$ & - & -- & - & - & -- & -- & $E, D$ & $A, E, M$ \\
\hline Brazil $\ldots \ldots \ldots \ldots \ldots \ldots$ & -- & -- & - & -- & -- & -- & -- & -- & -- & $e, M, P C$ \\
\hline Chile $\ldots \ldots \ldots \ldots \ldots \ldots$ & -- & - & - & -- & -- & - & -- & -- & -- & $M, P C$ \\
\hline Colombia $. . . . \ldots \ldots . .$. & -- & -- & - & DS & - & -. & -- & - & $E, D, P$ & $E, P, M, O P$ \\
\hline Costa Rica & -- & - & - & -- & - &.- & - & - & -- & M \\
\hline Dominican Republic ..... & -- & -- & -- & -- & - & -- & -- & - & -- & $\mathrm{R}, \bar{M}$ \\
\hline Ecuador......$\ldots \ldots$ & -- & - & -- & -- & -- & - & -- & A & -- & M \\
\hline El Salvador ............. & -- & -- & -- & -- & - & -- & - & -. & -- & $\mathrm{R}, \mathrm{M}$ \\
\hline Guatemala $\ldots \ldots \ldots \ldots$ & -- & -- & - & -- & - & -- & -- & -- & -- & M \\
\hline Honduras .............. & -- & - & - & -- & -- & -. & -- & -- & $\therefore$ & M \\
\hline Mexico $\ldots . . . . .$. & -- & $P G$ & -- & - & - & -- & -- & -- & $\therefore$ & M \\
\hline Nicaragua $\ldots \ldots \ldots \ldots$ & -- & -- & -- & -- & - &.- & - & -- & -.' & $M$ \\
\hline Panama $\ldots \ldots \ldots \ldots \ldots$ & -- & - & - & -- & - & -- & - & -- & -. & M \\
\hline Paraguay $\ldots \ldots \ldots \ldots$ & -- & - & - & -- & - & -- & - & -- & $\because$ & $M$ \\
\hline Peru...$\ldots \ldots \ldots \ldots$ & $e, d$ & PG & -- & -- & -- & -- & A & $A,-E, E$ & sw; $R$ & $A, j v-d, M$ \\
\hline Trinidad ................ & - & -- & $A, P$ & -- & - & -- & -- & -- & Ing & $\mathrm{A}, \mathrm{M}$ \\
\hline Uruguay $\ldots \ldots \ldots \ldots \ldots$ & -- & -- & -- & -- & -- & - & -- & -- & $\because$ & M \\
\hline Venezuela & - & .- & -- & DS & -- & IPP & - & - & $\therefore$ & $A, E, P, M, L N G, C P$ \\
\hline
\end{tabular}


Table A3. Privatization-motivated Energy Investment in Latin America (continued).

\begin{tabular}{|c|c|c|c|c|c|c|c|c|c|c|}
\hline Country of Incorporation & German & U.S. & U.S. & U.S. & U.S. & Spain & U.S. & U.S. & France & U.S. \\
\hline Company & $\begin{array}{c}\text { Ruhrkohle } \\
\text { AG }\end{array}$ & $\begin{array}{c}\text { Saba } \\
\text { Petroleum } \\
\text { Co. } \\
\end{array}$ & $\begin{array}{c}\text { San Diego } \\
\text { G\&E }\end{array}$ & $\begin{array}{c}\text { Sante Fe } \\
\text { Resources }\end{array}$ & $\begin{array}{c}\text { Scudder } \\
\text { Latin } \\
\text { American } \\
\text { Power } \\
\end{array}$ & $\begin{array}{c}\text { Sevillana } \\
\text { Electricidad }\end{array}$ & Shell oil & $\begin{array}{c}\text { Smith } \\
\text { Cogeneration }\end{array}$ & $\begin{array}{l}\text { Societe } \\
\text { Urbain }\end{array}$ & $\begin{array}{c}\text { Southern } \\
\text { California } \\
\text { Gas } \\
\end{array}$ \\
\hline $\begin{array}{l}\text { Primary Business of } \\
\text { Company (SIC Code) }\end{array}$ & 1222 & 1311. & 4931 & 1311 & - & $=$ & 2911 & - & 2813 & 4923 \\
\hline Parentsubsidiary & $=$ & $\begin{array}{c}\text { (subsidiary of } \\
\text { CAPCO } \\
\text { Resources, } \\
\text { Ltd.) } \\
\end{array}$ & - & $=$ & - & - & $\begin{array}{c}\text { (subsidlary of } \\
\text { Royal } \\
\text { Dutch/Shell) } \\
\end{array}$ & - & - & - \\
\hline Year of Annual Report & - & $\ldots$ & - & - & - & $=$ & 1995 & - & - & $\cdots$ \\
\hline \multicolumn{11}{|l|}{ Country } \\
\hline Argentina & - & .. & -- & $p, p g, g p$ & -- & - & - & -- & EPD & - \\
\hline Bolivia .............. & - & -- & - & $\mathrm{DR}$ & -. & - &.- & -- & -- & - \\
\hline Brazil $\ldots \ldots \ldots \ldots \ldots$ & - & -- & -- & -. & -. & - & -- & -- & -- & -- \\
\hline Chille $\ldots \ldots \ldots \ldots \ldots \ldots$ & - & -- & -- & - & -. & - & -- & -- & -- & -- \\
\hline Colombia $\ldots \ldots \ldots \ldots \ldots$ & - & $\mathbf{P}$ & - & -- & -- & CFP & -- & -- & -- & -- \\
\hline Costa Rica $\ldots \ldots \ldots \ldots$ & .- & -- & -- & -- & .. & -- & -- & -- & -- & -- \\
\hline Dominican Republic ...... & -- & -- & -- & -- & -- & - & -- & $\mathrm{pg}$ & -- & -- \\
\hline Ecuador $\ldots \ldots \ldots \ldots \ldots$ & -- & -- & -- & $\mathrm{a}, \mathrm{A}$ & -- & - & -- & -- & -- & -- \\
\hline El Salvador ............. & -- & -- & -- & -- & -- & -- & -- & -. & -- & -- \\
\hline Guatemala $\ldots \ldots \ldots \ldots$ & -- & -- & -- & -- & -- & -- & -- & -- & -- & -- \\
\hline Honduras $\ldots \ldots \ldots \ldots$ & .- & -- & -. & -- & .- & - & -- & -- & -- & -- \\
\hline Mexico $\ldots \ldots \ldots \ldots \ldots$ & -- & -- & jv-gd & -- & -- & -- & PC & -. & - & $g p$ \\
\hline Nicaragua...$\ldots \ldots \ldots$ & -- & -. & -- & -- & -- & -- & -- & -. & -- & -- \\
\hline Panama $\ldots \ldots \ldots \ldots \ldots$ & -. & -- & -- & -- & -- & - & - & -- & -- & -- \\
\hline Paraguay $\ldots \ldots \ldots \ldots \ldots$ & -- & -- & -- & -- & -- & -- & -- & -- & - & -- \\
\hline Peru....$\ldots \ldots \ldots \ldots$ & .. & -- & -. & - & A,gfe & - & - & -- &.- & - \\
\hline Trinidad...$\ldots \ldots \ldots \ldots$ & -- & - & -- & - & -- & -- & -- & -- & -- & $\cdots$ \\
\hline Uruguay $\ldots \ldots \ldots \ldots \ldots$ & -- & -- & -- & -- & -. & -. & -- & -- & -- & -- \\
\hline Venezuela .... & $\mathrm{CP}$ & $\ldots$ & -- & - & -. & - & -- & 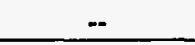 & -. & -- \\
\hline
\end{tabular}


Table A3. Privatization-motivated Energy Investment in Latin America (continued).

\begin{tabular}{|c|c|c|c|c|c|c|c|c|c|c|}
\hline Country of Incorporation & U.S. & U.S. & U.S. & Norway & U.S. & U.S. & Argentina & U.S. & U.S. & U.S. \\
\hline Company & $\begin{array}{l}\text { Southern } \\
\text { Company }\end{array}$ & $\begin{array}{c}\text { Southern } \\
\text { Electric } \\
\text { International }\end{array}$ & $\begin{array}{l}\text { Southwestern } \\
\text { Publlc Service }\end{array}$ & Statoil Norge A.S. & $\begin{array}{c}\text { Sun Co. } \\
\text { Inc. }\end{array}$ & $\begin{array}{c}\text { System } \\
\text { Energy } \\
\text { Resources }\end{array}$ & $\begin{array}{c}\text { Techint ClA } \\
\text { Technica } \\
\text { International } \\
\text { S.A. } \\
\end{array}$ & Tenneco Inc. & $\begin{array}{c}\text { Tesoro } \\
\text { Petroleum } \\
\text { Corp. }\end{array}$ & Texaco Inc. \\
\hline $\begin{array}{l}\text { Primary Business of } \\
\text { Company (SIC Code) }\end{array}$ & 4911 & 4911 & 4911 & 5541 & 2911 & 4911 & - & 3523 & 2911 & 1311 \\
\hline Parent/subsidiary & $\begin{array}{c}\text { (parent of } \\
\text { Southern } \\
\text { Electric } \\
\text { International) }\end{array}$ & $\begin{array}{l}\text { (subsidiary of } \\
\text { Southern Co.) }\end{array}$ & -- & -. & - & $\begin{array}{l}\text { (subsidiary } \\
\text { of Entergy) }\end{array}$ & 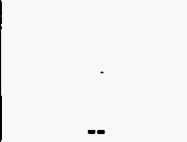 & - & -- & . \\
\hline Year of Annual Report & 1995 & - & $=$ & 1995 & - & - & .. & $\therefore$ & $\ldots$ & $\ldots$ \\
\hline \multicolumn{11}{|l|}{ Country } \\
\hline Argentina $\ldots \ldots \ldots$ & -- & - & $P G$ & - & -. & $P G$ & -- & $\mathrm{gp}$ & gp & $\dot{\mathrm{A}}$ \\
\hline Bolivia ................ & -- & - & -- & -- & - & $\therefore$ & -- & $\mathrm{gp}$ & E,P.gp & $A, E$ \\
\hline Brazil $\ldots \ldots \ldots \ldots \ldots$ & -. & -- & -- & -- & -- & - & -. & gfe,gp & $\mathrm{gp}$ & -- \\
\hline Chile $\ldots \ldots \ldots \ldots \ldots \ldots$ & PG,EPT & PG,EPT & .- & -- & -- & -- & -. & $g p$, gfe & gp & -- \\
\hline Colombia $\ldots \ldots \ldots \ldots$ & -- & -- & $\therefore$ & -- & $D R,-P$ & -- & $\therefore$ & -- & -- & $-A, \Theta, P, g p$ \\
\hline Costa Rica $\ldots \ldots \ldots \ldots$ & -. & - & -. & -- & -- & -- & -- & -- & -- & -- \\
\hline Dominican Republic ..... & -- & - & -. & -- & -- & - & -. & - & - & -- \\
\hline Ecuador $\ldots \ldots \ldots \ldots \ldots$ & -- & - & $P G$ & -- & - & -- & -- & -- & -- & -- \\
\hline El Salvador $\ldots \ldots \ldots \ldots$ & -- & -- & .- & -- & - & -- & -. & -- & -- & -. \\
\hline Guatemala $\ldots \ldots \ldots \ldots$. & -- & -- & -- & -- & - & -- & -. & -. & -- & -. \\
\hline Honduras $\ldots \ldots \ldots \ldots \ldots$ & -- & - & -- & -- & - & -- & -- & -- & -- & -. \\
\hline Mexico $\ldots \ldots \ldots \ldots \ldots$ & -- & -- & -- & - & -- & -- & -- & $\mathrm{gp}$ & -- & $\therefore$ \\
\hline Nicaragua $\ldots \ldots \ldots \ldots \ldots$ & -- & - & -- & -- & -- & -- & -. & -. & - - & -- \\
\hline Panama $\ldots \ldots \ldots \ldots \ldots$ & -- & - & $\because-$ & -- & -- & $\cdots$ & -- & -- & -- & $\therefore$ \\
\hline Paraguay $\ldots \ldots \ldots \ldots$ & -- & -- & -- & -- & -- & -- & -- & -. & - & $A, E$ \\
\hline Pera $: \ldots \ldots \ldots \ldots \ldots$ & -- & -- & -- & -- & - & -- & $\cdots$ & -- & -- & $m, L$ \\
\hline Trinidad...$\ldots \ldots \ldots \ldots$ & CFP,PG, GFE & GFE & -. & -- & - & -- & -- & $\because$ & -- & $P$ \\
\hline Unuguay $\ldots \ldots \ldots \ldots \ldots$ & ns & - & -. & - & -- & - & gs & - & -- & -. \\
\hline Venezuela $\ldots \ldots \ldots \ldots$ & - & - & -- & P,eor, jv-orimulsion & -- & -- & -- & -- & -- & -- \\
\hline
\end{tabular}


Table A3. Privatization-motivated Energy Investment in Latin America (continued).

\begin{tabular}{|c|c|c|c|c|c|c|c|c|c|c|}
\hline Country of Incorporation & U.S. & Japan & France & Canada & Canada & U.S. & U.S. & U.S. & U.S. & U.S. \\
\hline Company & $\begin{array}{c}\text { Texas } \\
\text { Utilities } \\
\text { Company }\end{array}$ & Tomen Corp. & TOTAL & $\begin{array}{c}\text { Transalta } \\
\text { Energy }\end{array}$ & $\begin{array}{c}\text { TransCanada } \\
\text { Pipelines }\end{array}$ & $\begin{array}{c}\text { Triton Energy } \\
\text { Corp. }\end{array}$ & $\begin{array}{c}\text { Tuboscope } \\
\text { Vetco } \\
\text { International } \\
\text { Corp. } \\
\end{array}$ & $\begin{array}{c}\text { Union Texas } \\
\text { Petroleum }\end{array}$ & Unocal Corp & $\begin{array}{c}\text { Valero } \\
\text { Energy Corp. }\end{array}$ \\
\hline $\begin{array}{l}\text { Primary Business of } \\
\text { Company (SIC Code) }\end{array}$ & 4911 & $\cdots$ & 1311 & 4911 & 4923 & 1311 & 1389 & 1311 & 2911 & 2911 \\
\hline Parent/subsidiary & $\begin{array}{l}\text { (parent of } \\
\text { Basic } \\
\text { Resources) }\end{array}$ & -- & -- & -- & - & - & -- & 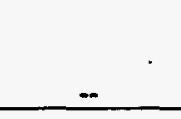 & - & -- \\
\hline Year of Annual Report & 1995 & 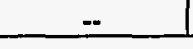 & 1995 & - & - & 1995 & 1995 & -- & 1995 & - \\
\hline \multicolumn{11}{|l|}{ Country } \\
\hline Argentina $\ldots \ldots \ldots \ldots \ldots$ & -- & -- & $P$ & HE & -- & $A, E$ & $E S, C W$ & $E$ & A & -- \\
\hline Bolivia ................ & - & -- & $A, E$ & -- & -- & - & -- & -- & -- & -- \\
\hline Brazil $\ldots . . . \ldots \ldots \ldots$ & - & -- & -- & -- & - & -- & $*$ & -- & -- & -- \\
\hline Chile .................. & - & - & -- & -- & - & - & -- & -- & -- & -- \\
\hline Colombia...$\ldots \ldots \ldots$ & - & gp & $A, P, O P$ & -- & op & $A, P, O P$ & O० & $\cdots$ & $-\cdots$ & -- \\
\hline Costa Rica ............. & - & - & -- & -- & - & -- & -- & -- & -- & - \\
\hline Dominican Republic ...... & -- & - & -- & -- & -- & -- & -- & $\cdots$ & - & -- \\
\hline Ecuador............ & - & -- & - & -- & -- & $A, \theta,-A$ & - & - & - & -- \\
\hline El Salvador ............. & -- & -- & - & -- & - & -- & -- & -- & - & -- \\
\hline Guatemala...$\ldots \ldots \ldots$ & op, $R$ & -- & - & -- & - & A & -- & -- & - & -- \\
\hline Honduras........... . & - & -- & - & - & - & -- & -- & -- & -- & -- \\
\hline Mexico ................ & - & -- & -- & -- & gp & -- & * & -- & -- & pc \\
\hline Nicaragua...$\ldots \ldots \ldots \ldots$ & $-\cdots$ & - & - & -- & - & -- & -- & -- & -- & -- \\
\hline Panama ............... & -- & - & - & $\cdots$ & - & -- & -- & -- & -- & -- \\
\hline Paraguay $\ldots \ldots \ldots \ldots$ & - & - & - & -- & - & -- & - & -- & -- & -- \\
\hline Peru .................. & -- & -- & $-\infty$ & -- & - & -- & - & -- & -- & -- \\
\hline Trinidad............... & -- & -- & - & -- & -- & -- & - & -- & $\mathrm{DR}, \boldsymbol{\theta}$ & -- \\
\hline Uruguay.$\ldots \ldots \ldots \ldots \ldots$ & -- & -- & M & -- & -- & -- & -- & -- & -- & -- \\
\hline Venezuela...$\ldots \ldots \ldots$ & -- & -- & $E$ & - & $\approx$ & 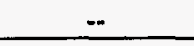 & * & $\ldots$ & -- & -- \\
\hline
\end{tabular}


Table A3. Privatization-motivated Energy Investment in Latin America (continued).

\begin{tabular}{|c|c|c|c|c|c|c|c|}
\hline Country of Incorporation & Germany & U.S. & Finland & Germany & U.S. & Argentina & S.Korea \\
\hline Company & Veba AG & Vintage Petroleum & Wartsila Dlesel & Wintershall & WPL Holdings & YPF & Yukong Limited \\
\hline $\begin{array}{l}\text { Primary Business of } \\
\text { Company (SIC Code) }\end{array}$ & 5122 & 1311 & - & 2911 & 4931 & 1311 & 2911 \\
\hline Parentsubsidiary & - & $\ddot{-}$ & - & -- & -- & $\begin{array}{c}\text { (Parent of Maxus } \\
\text { Energy Corp.) }\end{array}$ & $=$ \\
\hline Year of Annual Report & - & 1995 & - & 1994 & - & $\ldots$ & 1995 \\
\hline \multicolumn{8}{|l|}{ Country } \\
\hline Argentina .......... & $P$ & $A, P$ & OFP & -- & - & -- & - \\
\hline Bollivia ............... & -- & -. & $\cdots$ & $-\cdots$ & -- & $\mathrm{DR}, \mathrm{E}, \mathrm{M}$ & - \\
\hline Brazil $\ldots \ldots \ldots \ldots \ldots$ & -- & -. & -- & -- & -- & -. & -- \\
\hline Chille $\ldots \ldots \ldots \ldots \ldots$ & - & -- & -- & -- & -- & $E, M$ & -- \\
\hline Colombia...$\ldots \ldots \ldots$ & -- & -- & -- & -- & - & * & -- \\
\hline Costa Rica $\ldots \ldots \ldots \ldots$ & -- & -. & -- & -- & -- & - & -- \\
\hline Dominican Republic .... & -- & -- & -- & -- & - & - & -- \\
\hline Ecuador.......... & -- & A & -- & - & - & $P$ & $A, \Theta$ \\
\hline El Salvador $\ldots \ldots \ldots \ldots$ & - & -- & -- & -- & -- & -- & -- \\
\hline Guatemala $\ldots \ldots \ldots \ldots$ & -- & -- & -- & -- & -. & -- & -- \\
\hline Honduras $\ldots \ldots \ldots \ldots$ & -- & -. & $\therefore$ & -- & -- & -- & -- \\
\hline Mexico........... & - & -- & -- & - & NS & - & $\therefore$ \\
\hline Nicàragua ............ & -- & -- & -- & - & - & - & -- \\
\hline Panama $\ldots \ldots \ldots \ldots \ldots$ & -- & -- & -- & - & -- & -- & -- \\
\hline Paraguay $\ldots \ldots \ldots \ldots$ & -- & - & $\because$ & -- & -- & - & - \\
\hline Peru...$\ldots \ldots \ldots \ldots$ & A & -- & -- & -- &.-- & $A,-A, M$ & -- \\
\hline 'Trinidad ............... & A & -. & $\cdots$ & A & - & -- & -. \\
\hline Uruguay $\ldots \ldots \ldots \ldots \ldots$ & - & -- & -- & -. & -- & .- & .- \\
\hline Venezuela $\ldots \ldots \ldots \ldots$ & $A, E$ & $\ldots$ & - & -- & - & A & .. \\
\hline
\end{tabular}

Sources: Various company annual reports; The Mead Corporation, Lexis-Nexis; Disclosure Incorporated, Compact Dlsclosure and Worldscope Disclosure; and U.S. Department of Energy, Office of Oil and Natural Gas Policy, U.S. Energy Ventures in Latin America (March 1996). 
Table A4. Privatization-motivated Energy Investment in Socialist and Formerly-Socialist Nations.

\begin{tabular}{|c|c|c|c|c|c|c|c|c|c|c|}
\hline Country of Incorporation & $\begin{array}{c}\text { Sweden/ } \\
\text { Switzerfand } \\
\end{array}$ & U.S. & U.S. & U.S. & Germany & U.S. & U.S. & U.S. & British V.I. & U.K. \\
\hline Company & $\begin{array}{c}\text { ABB Energy } \\
\text { Ventures }\end{array}$ & AES Corp & $\begin{array}{l}\text { American } \\
\text { Electric } \\
\text { Power Co } \\
\end{array}$ & Amoco & Aral & ARCO & $\begin{array}{c}\text { Benton Oll \& } \\
\text { Gas Co. }\end{array}$ & Blue Star & Bridas Corp & British Gas \\
\hline $\begin{array}{l}\text { Primary Business of } \\
\text { Company (SIC Code) }\end{array}$ & 3823 & 4911 & 4911 & 2911 & - & 1311 & 1311 & - & 1311 & 4923 \\
\hline Parent/subsidiary & - & -- &.- & - & - & - & - & - & -- & - \\
\hline Year of Annual Report & - & 1995 & 1995 & 1995 & - & 1995 & - & - & - & 1995 \\
\hline \multicolumn{11}{|l|}{ Country } \\
\hline Albania ............ & -- & $-\cdot$ & - & -- & - & $-\cdot$ & -- & -- & -- & -- \\
\hline Armenia...$\ldots \ldots$. & -- & -- & - & - & - &.- & -- & - & - & - \\
\hline Azerbaljan $\ldots \ldots \ldots$ & - & -- & -- & $\mathbf{D}$ & - & -- & - & -- & -- & $\cdots$ \\
\hline Belarus ............ & -- & -- & - & -- & - & -- & - & - & - & -- \\
\hline Bulgaria .......... & - & -- & -- & -- & -- & -- & - & - & -- & $A,-E, r$ \\
\hline Croatia ............ & $\cdots$ & -- & -- & $\mathrm{m}$ & - & -- & - & -- & -- & -- \\
\hline Czech ............ & -- & -- & -- & -- & -- & -- & -- & -- & -- & -. \\
\hline Estonia ........... & -- & -- & - & -- & -- & -- & -- & -- & -- & -. \\
\hline Georgia............ &.- & -- & -- & -- & -- & -- & -- & -- & -- & $-\cdot$ \\
\hline Hungary...$\ldots \ldots \ldots$ & - & * & -- & -- & -- & -- & -- & jV-A & -- & -. \\
\hline Kazakhstan ......... & -- & -- & -- & -- & -- & -- & -- & -- & -- & $E, j V-P, M, O P, S W$ \\
\hline Kyrgyzstan ......... & -- & -- & -- & -- & -- & -- & -- & -- & -- & - \\
\hline Latvia ........... & -- & -- & -- & $j v-d$ & -- & -. & -- & -- & - & - \\
\hline Lithuania ........... & - & -- & -- & -- & - & -- & -- & -- & -- & - \\
\hline Poland...$\ldots \ldots \ldots$ & $-\cdot$ & * & -- & $A, E, M$ & M & -- & -- & -- & - & $A, a$ \\
\hline Romania $\ldots \ldots \ldots$ & - & - & -- & $A, E, m$ & $\cdots$ & A & -- & -- & $\cdots$ & - \\
\hline Russia $\ldots \ldots \ldots \ldots$ & $\cdots$ & -- & $c W$ & $E, D$ & -- & $E, D, R, M$ & $p$ & -- & -- & $g p, P$ \\
\hline Șlovakia ........... & $\cdots$ & - & -- & -- & -- & -- & -- & -- & -- & $\cdots$ \\
\hline Slovenia ........... & - & - & -- & -- & -- & -- & -- & -- & -- & - \\
\hline Tajlkistan $\ldots \ldots \ldots$ & $-\infty$ & -. & -- & -- & -- & -- & -- & -- & -- & - \\
\hline Turkmenistan ........ & - & - &.- & -- & -- & -- & -- & -- & $\mathbf{P}$ & -- \\
\hline Ukraine ............. & -- & - & -- & - & $\cdots$ & - & -- & - & -- & a \\
\hline Uzbekistan .......... & pc & - & -. & -- & - & -- & -- & -- & -. & - \\
\hline Yugoslavia .......... & - & - & -- & - & $\cdots$ & - & -- & - & -- & - \\
\hline
\end{tabular}


Table A4. Privatization-motivated Energy Investment in Socialist and Formerly-Socialist Nations (Continued).

\begin{tabular}{|c|c|c|c|c|c|c|c|c|c|c|}
\hline Country of Incorporation & U.K. & Australia & Canada & U.S. & U.S. & U.S. & U.S. & U.K. & German & U.S. \\
\hline Company & $\begin{array}{c}\text { British } \\
\text { Petroleum }\end{array}$ & $\begin{array}{c}\text { Broken HIII } \\
\text { Proprietary } \\
\text { Company } \\
\end{array}$ & $\begin{array}{l}\text { Canadian } \\
\text { Occidental }\end{array}$ & Chevron & Cinergy & $\begin{array}{c}\text { Coastal } \\
\text { Corporation }\end{array}$ & Conoco & $\begin{array}{c}\text { Dana } \\
\text { Petroleum } \\
\text { PLC } \\
\end{array}$ & Deminex & $\begin{array}{l}\text { E.l. du Pont } \\
\text { de Nemours }\end{array}$ \\
\hline $\begin{array}{l}\text { Primary Business of } \\
\text { Company (SIC Code) }\end{array}$ & 2911 & 3312 & 1311 & 1311 & 4931 & 2911 & 2911 & -- & - & 2911 \\
\hline Parentsubsidiany & - & - & -- & - & - & $\therefore$ & $\begin{array}{c}\text { (subsidlary of } \\
\text { du Pont) }\end{array}$ & - & $\begin{array}{c}\text { (affiliate of } \\
\text { Wintershall) } \\
\end{array}$ & $\begin{array}{c}\text { (parent of } \\
\text { Conoco) }\end{array}$ \\
\hline Year of Annual Report & 1995 & $=$ & 1995 & 1995 & 1995 & 1995 & .. & .. & 1994 & - \\
\hline
\end{tabular}

\section{Country}

Albania ...............

Amenia

Azemailan $\ldots \ldots \ldots \ldots . . . . . .$.

$--\quad A, E$

Belarus.

Bulgaria

Croatia

Czech

Estonia

Georgia ....

Hungary

Kazakhstan

Kyrgyzstan

Latvia .

Lithuania

Poland

Romania .

Russia

Slovakià ...

Slovenia ...

Tajikistan

Turkmenistan

Ukraine

Uzbekistan

Yugoslavia

jv-a,D

--

$--$

$-$

M

--

$-$

$M$

jv-E,SW

$-$

$-$

m

m

m

m

"

$-$

--

$-$

\begin{tabular}{|c|c|c|}
\hline$A, E, D$ & -. & A \\
\hline -- & -- & -- \\
\hline -- & -- & a \\
\hline -- & -- & -- \\
\hline -- & -- & - \\
\hline -- & -- & -- \\
\hline -- & -- & -- \\
\hline -- & -- & -- \\
\hline -- & -- & -- \\
\hline -- & -- & -- \\
\hline -- & $D, p$ & $D, j v-P, O P$ \\
\hline -- & -- & -- \\
\hline -- & -- & -- \\
\hline-- & -- & -- \\
\hline -- & -- & ES \\
\hline -- & JV-A,E & -- \\
\hline$E$ & -- & -- \\
\hline -- & -- & -- \\
\hline -- & -- & -- \\
\hline -- & -- & -- \\
\hline -. & -- & $\therefore$ \\
\hline -- & -- & -- \\
\hline -- & -- & .- \\
\hline$E, D, P$ & - & .- \\
\hline
\end{tabular}

$-$

-

(2)

$+2$

1994


Table A4. Privatization-motivated Energy Investment in Socialist and Formerly-Socialist Nations (Continued).

\begin{tabular}{|c|c|c|c|c|c|c|c|c|c|c|}
\hline Country of Incorporation & France & France & U.S. & Italy & U.K. & U.S. & U.S. & France & Russia & U.S. \\
\hline Company & $\begin{array}{l}\text { Electricite de } \\
\text { France (EdF) }\end{array}$ & Elf Aquitaine & Enron & $\begin{array}{c}\text { Ente } \\
\text { Nazionale } \\
\text { Idrocarburl } \\
\text { (ENI) }\end{array}$ & Enterprise Oil & Enterra Corp. & Exxon & $\begin{array}{l}\text { Gaz de } \\
\text { France }\end{array}$ & Gazprom & $\begin{array}{c}\text { Global } \\
\text { Natural } \\
\text { Resources }\end{array}$ \\
\hline $\begin{array}{l}\text { Primary Business of } \\
\text { Company (SIC Code) }\end{array}$ & 4911 & 2911 & 1321 & 2911 & 1311 & 7359 & 1311 & 4923 & - & 1311 \\
\hline Parent/subsidiary & - & - & -- & $\begin{array}{c}\text { (parent of } \\
\text { AGIP) }\end{array}$ & - & - & - & - & - & - \\
\hline Year of Annual Report & $\ldots$ & 1995 & 1995 & 1994 & 1995 & - & 1995 & $\ldots$ & - & -- \\
\hline \multicolumn{11}{|l|}{ Country } \\
\hline Albania .............. & $\cdots$ & -- & - & $-A$ & -- & - & & - & - & -- \\
\hline Armenia...$\ldots \ldots \ldots$ & -- & -- & - & -- & -- & - & & - & - & - \\
\hline Azerbaijan..$\ldots \ldots \ldots$ & -- & e & - & D & - & -- & $O O, \Theta, E, D$ & gp & -- & -- \\
\hline Belarus ............ & -- & -- & -- & - & - & -- & & - & - & -- \\
\hline Bulgaria $\ldots \ldots \ldots \ldots$ & -- & A & -- & - & $A, E, r$ & - & & - & Jv-gp & -- \\
\hline Croatia...$\ldots \ldots \ldots$ & -- & - & -- & - & - & $\cdots$ & & $-\cdot$ & -- & - \\
\hline Czech ............ & -- & -- & - & JV-R,M & -. & - & $M$ & - & - & - \\
\hline Estonia ............ & -- & -- & -- & - & -- & - & & - & -- & -- \\
\hline Georgia............. & -- & -- & -- & - & -- & $\cdots$ & & $\cdots$ & -- & - \\
\hline Hungary ............ & $P G$ & -- & - & - & -- & -. & $M$ & -- & -- & - \\
\hline Kazakhstan ......... & - & E &.- & E,jV-P,OP,SW & -- & $\mathrm{cW}$ & $O O, S W, E, \theta$ & * & $j v-P$ & -- \\
\hline Kyrgyzstan .......... & - & -- & -- & - & -- & -. & & - & -- & -- \\
\hline Latvia ............. & - & -- & $\cdots$ & - & -- & -- & & -- & -- & -- \\
\hline Lithuania ............ & - & - & -- & -- & -- & -. & -- & -- & $-\cdot$ & -- \\
\hline Poland $\ldots \ldots \ldots \ldots \ldots$ & CFP & -- & $P G$ & $M$ & -- & -- & $a, M$ & -- & -- & -- \\
\hline Romania ............ & - & A & -. & - & $j v-A, m$ & -- & -- & -- & -- & -- \\
\hline Russia $\ldots \ldots \ldots \ldots$ & - & $a,-A$ & -- & $D, j v-P$, & -- & -- & $O O, E, e, D$ & gp,jv & - & $\mathrm{p}$ \\
\hline Slovakia ............ & - & - & -- & $j v-M$ & -- & -. & $M$ & GS & -- & -- \\
\hline Slovenia ........... & -- & -- & -- & - & -- & -- & -- & -- & -- & -- \\
\hline Tajjkistan ........... & -- & - & -- & -- & -- & $m$ & -- & - & -- & - \\
\hline Turkmenistan ........ & - & - & -. & -- & - & $\cdots$ & - & -- & -. & - \\
\hline Ukraine ............ & -- & -- & -- & - & -- & -- & -- & -- & -- & -- \\
\hline Uzbekistan .......... & - & - & $E, D$ & -- & - & -. & -- & -. & -- & -- \\
\hline Yugoslavia . & -- & -- & .- & - & -- & -. & -- & -. & -- & -- \\
\hline
\end{tabular}


Table A4. Privatization-motivated Energy Investment in Socialist and Formerly-Socialist Nations (Continued).

\begin{tabular}{|c|c|c|c|c|c|c|c|c|c|c|}
\hline Country of Incorporation & Russia & Germany & U.S. & U.S. & U.S. & Japan & Japan & U.S. & Iran & Finland \\
\hline Company & Lukoil & Mannesman & $\begin{array}{c}\text { Marathon OII } \\
\text { Co. }\end{array}$ & $\begin{array}{c}\text { Maxus } \\
\text { Energy Corp. }\end{array}$ & $\begin{array}{l}\text { McDermott } \\
\text { International }\end{array}$ & Mitsubishi & Mitsui \& Co. & Mobil & $\begin{array}{c}\text { National } \\
\text { Iranian Oil } \\
\text { Co. }\end{array}$ & Neste Oy \\
\hline $\begin{array}{l}\text { Primary Business of } \\
\text { Company (SIC Code) }\end{array}$ & - & 3560 & 1311 & 1311 & 1629 & 5050 & 6221 & 1311 & - & 2911 \\
\hline Parent/subsidiary & - & - & $\begin{array}{c}\text { (subsidiary of } \\
\text { USX) }\end{array}$ & $\begin{array}{c}\text { (subsidiary of } \\
\text { YPF) }\end{array}$ & - & - & $\ldots$ & -- & -- & -- \\
\hline Year of Annual Report & - & - & - & - & - & $=$ & -- & 1995 & - & -- \\
\hline \multicolumn{11}{|l|}{ Country } \\
\hline Albania & -- & -- & -- & $\therefore$ & -- & -- & -- & .- & -- & -- \\
\hline Armenia $\ldots \ldots \ldots \ldots \ldots$ & - & -- & -- & -- & -- & -- & -- & .- & .. & - \\
\hline Azerbaljan $\ldots \ldots \ldots \ldots$ & D & -- & -- & .- & D & -- & .- & a & -. & -_ \\
\hline Belarus $\ldots \ldots \ldots \ldots \ldots$ & -- & -- & -- & - & -. & -- & -- & -. & -- & -- \\
\hline Bulgaria $\ldots \ldots \ldots \ldots \ldots$ & -- & -- & -- & A & -- & -- & -- & -. & -- & -- \\
\hline Groatia $\ldots \ldots \ldots \ldots \ldots \ldots$ & -- & - & -- & -. & -- & -- & .- & -- & -- & -- \\
\hline Czech ................ & -- & - & -- & -- & - & -- & -- & -- & - & -- \\
\hline Estonia $\ldots \ldots \ldots \ldots \ldots$ & -- & -- & -- & -- & -- & -- & -. & -. & -- & M \\
\hline Georgia ............... & -- & - & -- & -- & -- & -- & -- & -. & -- & -- \\
\hline Hungary,.$\ldots \ldots \ldots \ldots$ & -- & -- & -- & - & - & - & -- & $\mathrm{jv}-\mathrm{A}, \mathrm{M}$ & - & -- \\
\hline Kazakhstan ............ & OP & -- & -- & -- & -- & -- & -- & $\begin{array}{c}S W, j v-E, D, P, \\
\text { OP }\end{array}$ & -- & -- \\
\hline Kyrgyzstan $\ldots \ldots \ldots \ldots$ & -- & -- & -- & .. & .. & .- & .- & .- & .- & -- \\
\hline Latvia .................. & -- & -- & -- & $\cdots$ &.- & -- & -- & -- & -- & M \\
\hline Llthuania ................ & -- & -- & - & -- & - & -- & -- & -- & $-s$ & M \\
\hline Poland $\ldots \ldots \ldots \ldots \ldots$ & -- & - & - & -- & -- & -- & -- & M & -- & M \\
\hline Romania $\ldots \ldots \ldots \ldots \ldots$ & -- & -- & -- & -- & $-\cdot$ & -- & $-=$ & -- & -- & $\cdots$ \\
\hline Russia $\ldots \ldots \ldots \ldots \ldots$ & -- & - & $E, D$ & - & $D$ & $E, D$ & $E, D$ & $e, d, M$ & -- & M \\
\hline Slovakia .............. & -- & -- & -- & - & -- & - & -- & -- & -- & - \\
\hline Slovenia $\ldots \ldots \ldots \ldots \ldots$ & -. & -- & - & -- & -- & -- & -- & $\therefore$ & -- & -. \\
\hline Tajkistan $\ldots \ldots \ldots \ldots \ldots$ & $\therefore$ & -- & - & -- & -- & -- & -- & -. & -- & -- \\
\hline Turkmenistan ........... & -- & $r$ & - & - & -- & -- & -- & -- & $\mathrm{r}$ & -- \\
\hline Ukraine ................ & $-\cdot$ & -- & $\therefore$ & $\therefore$ & -- & -. & -- & -- & -- & -- \\
\hline Uzbekistan ............ & -- & -. & -. & -- & -- & -- & $r$ & -. & $=$ & -- \\
\hline Yugoslavia ........ & $=$ & -. & -- & - & $\ldots$ & -. & -- & -. & -- & -- \\
\hline
\end{tabular}


Table A4. Privatization-motivated Energy Investment in Socialist and Formerly-Socialist Nations (Continued).

\begin{tabular}{|c|c|c|c|c|c|c|c|c|c|c|}
\hline Country of Incorporation & Norway & U.S. & U.S. & U.S. & Sweden & Austria & U.S. & U.S. & Oman & U.K. \\
\hline Company & Norsk Hydro & $\begin{array}{l}\text { Northern } \\
\text { States Power }\end{array}$ & NRG Energy & Occidental & $\begin{array}{c}\text { OK } \\
\text { Petroleum } \\
\end{array}$ & OMV & $\begin{array}{c}\text { Oryx Energy } \\
\text { Co. }\end{array}$ & Pennzoil & $\begin{array}{c}\text { Petroleum } \\
\text { Development } \\
\text { Co of Oman }\end{array}$ & $\begin{array}{c}\text { PowerGen } \\
\text { PLC }\end{array}$ \\
\hline $\begin{array}{l}\text { Primary Business of } \\
\text { Company (SIC Code) }\end{array}$ & 2870 & 4931 & 4931 & 2812 & - & 2911 & 1311 & 2911 & - & 4911 \\
\hline Parent/subsidiary & - & $\begin{array}{c}\text { (parent of } \\
\text { NRG Energy) }\end{array}$ & $\begin{array}{c}\text { (subsidiary of } \\
\text { Northern } \\
\text { States Power) }\end{array}$ & $=$ & - & $=$ & - & - & - & - \\
\hline Year o & 1994 & 1995 & & 1995 & - & $=$ & 1995 & & - & \\
\hline
\end{tabular}

\section{Year of Annual Report}

1995

\section{Albania}

Armenia

Azerbaljan

Belarus .

Bulgaria

Croatia

Czech

Estonia

Georgia

Hungary

Kazakhstan

Kyrgyzstan

Latvia ...

Lithuania

Poland

Romania

Russia

-

$-$

Slovakia

Slovenia

Tajikistan

Turkmenistan

Ukraine.

Uzbekistan

$-$

$-$

$-$

$\cdots$

Yugoslavia

\begin{tabular}{l}
-- \\
- \\
-- \\
-- \\
- \\
- \\
- \\
- \\
- \\
-- \\
- \\
- \\
- \\
- \\
- \\
- \\
- \\
- \\
- \\
- \\
- \\
- \\
- \\
- \\
- \\
\hline
\end{tabular}

A

$-$

A

A

$-$

$-$

$$
\text { -- }
$$

$-$

$$
--
$$$$
-
$$$$
-
$$$$
-
$$$$
\text { ED }
$$

$-\cdot$

$-$

$-$

--

-
+
+
-
--
--
--
--
--
-
-
--
--
--
--
--
-
--
--
-

$-$

$-$

$-$

$-$

jv-A

$-$

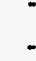

$-$

--

$A, D R$

jV-E,EOR

-.

-.

-.

$-$

--

\begin{tabular}{|c|c|c|}
\hline-- & -- & - \\
\hline-- & -- & -- \\
\hline$D$ & - & -- \\
\hline -- & -- & -- \\
\hline -- & -- & -- \\
\hline-- & -- & -- \\
\hline -. & -- & -- \\
\hline -- & -- & - \\
\hline -. & -- & -- \\
\hline -. & -- & IPP \\
\hline -- & OP & -- \\
\hline -- & .- & -- \\
\hline -- & -. & -- \\
\hline -- & -- & -- \\
\hline -- & -- & -- \\
\hline -- & -- & -- \\
\hline * & -- & -- \\
\hline -- & -- & -- \\
\hline -- & -- & -- \\
\hline -- & -- & -- \\
\hline -. & -- & -- \\
\hline-- & -. & -- \\
\hline -. & -. & -- \\
\hline .. & -- & -- \\
\hline
\end{tabular}

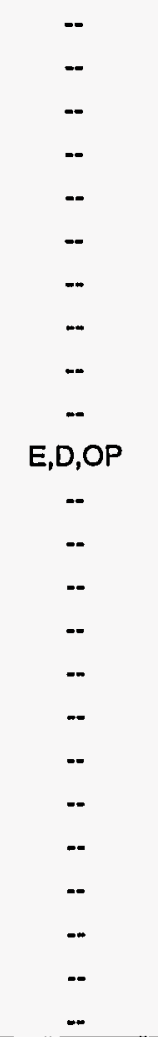


Table A4. Privatization-motivated Energy Investment in Socialist and Formerly-Socialist Nations (Continued).

\begin{tabular}{|c|c|c|c|c|c|c|c|c|c|c|}
\hline Country of Incorporation & U.K. & U.S. & Russia & $\begin{array}{l}\text { The } \\
\text { Netherlands } \\
\text { IUK }\end{array}$ & U.S. & U.S. & Norway & U.S. & U.S. & U.S. \\
\hline Company & $\begin{array}{l}\text { Premier Oil } \\
\text { PLC }\end{array}$ & $\begin{array}{c}\text { Pride } \\
\text { Petroleum }\end{array}$ & Rosneft & $\begin{array}{c}\text { Royal } \\
\text { Dutch/Shell }\end{array}$ & $\begin{array}{l}\text { Samson } \\
\text { Investment } \\
\text { Company }\end{array}$ & $\begin{array}{c}\text { Snyder Oll } \\
\text { Corp }\end{array}$ & $\begin{array}{c}\text { Statoll Norge } \\
\text { A.S. }\end{array}$ & Tenneco Inc. & Texaco Inc. & $\begin{array}{l}\text { Thermo } \\
\text { EcoTek }\end{array}$ \\
\hline $\begin{array}{l}\text { Primary Business of } \\
\text { Company (SIC Code) }\end{array}$ & 1311 & 1389 & $\ldots$ & 1311 & - & 1311 & 5541 & 2653 & 1311 & 4911 \\
\hline Parent/subsidiary & - & - & - & -- & - & -- & -- &.- & -- & $\ldots$ \\
\hline Year of Annual Report & 1995 & 1995 & -- & 1995 & - & 1995 & 1995 & .- & - & .- \\
\hline
\end{tabular}

\section{Country}

Albania

Armenia .

Azerbaijan

Belarus ...

Bulgaria

Croatia

Czech

Estonia

Georgla

Hungary

Kazakhstan

Kyrgyzstan

Latvia

Lithuania

Poland

Romania

Russia

Slovakia

Slovenia

Tajikistan

Turkmenistan

Ukraine . .

Uzbekistan

Yugoslavia .........

\begin{tabular}{|c|c|c|c|}
\hline$A, E$ & -- & - & $E$ \\
\hline -- & -- & - & -. \\
\hline -- & -- & -- & -- \\
\hline- & -- & -- & -- \\
\hline-- & -- & - & $M$ \\
\hline- & -- & -. & $M$ \\
\hline -. & -- & - & $j v-R, M$ \\
\hline-- & -- & -- & $M$ \\
\hline- & -- & -- & -- \\
\hline-- & -- & -- & $M$ \\
\hline-- & -- & -- & sw \\
\hline-- & -- & -- & -- \\
\hline-- & -- & - & $M$ \\
\hline-- & -- & - & $M$ \\
\hline-- & -- & - & $A, M$ \\
\hline- & -- & $\cdots$ & $A, E, M$ \\
\hline- & DS & $P, R, M$ & $E, D, P, M$ \\
\hline-- & -- & - & $M$ \\
\hline-- & - & -- & $M$ \\
\hline-- & $\cdots$ & -- & -- \\
\hline-- & - & -- & -- \\
\hline-- & -- & - & - \\
\hline- & -- & -- & - \\
\hline
\end{tabular}

$\begin{array}{ccc}-- & -- & -- \\ -- & -- & \text { jv-a,D } \\ -- & -- & -- \\ -- & -- & -- \\ -- & -- & -- \\ -- & -- & -- \\ -- & -- & M \\ -- & -- & - \\ -- & - & - \\ -- & -- & \text {,SW,E } \\ \text { jv-P } & -- & - \\ -- & -- & M \\ -- & -- & M \\ -- & -- & M \\ -- & -- & -- \\ -- & -- & -- \\ -- & P, O P & -- \\ -- & -- & -- \\ -- & -- & -- \\ -- & -- & -- \\ -- & -- & - \\ -- & -- & - \\ -- & -- & -\end{array}$

-
--
-
--
-
$P G$
--
-
-
-
-
--
-
-
-
-
-
--
-
-
-
-
-


Table A4. Privatization-motivated Energy Investment in Socialist and Formerly-Socialist Nations (Continued).

\begin{tabular}{l|c|c|c|c|c}
\hline Country of Incorporation & France & Belgium & U.S. & Switzerland & Germany \\
\hline Company & TOTAL & Tractebel SA & Unocal Corp & Vitol & Wintershall \\
\hline $\begin{array}{l}\text { Primary Business of } \\
\text { Company (SIC Code) }\end{array}$ & 1311 & 4931 & -2911 & - & 2911 \\
\hline Parentsubsidiary & - & - & - & - & - \\
\hline Year of Annual Report & 1995 & - & 1995 & - & 1994 \\
\hline
\end{tabular}

\section{Country}

Albania ..............

Amenia

Azerbaljan $. . . . . \ldots .$.

Belarus

Bulgaria

Croatia

Czech .............

Estonla ...

Georgia .............

Hungary .............

Kazakhstan .........

Kyrgyzstan ...........

Latvia .............

Lithuania .............

Poland ............

Romania .............

Rusșia .............

Slovakia

Slovenia .............

Tajikistan

Turkmenistan ........

Ukraine .

Uzbekistan

Yugoslavia .

$-$

$-$

Various company annual reports; The Mead Corporation, Lexis-Nexis; Disclosure Incorporated, Compact Disclosure and Worldscope Disclosure; U.S. Department of Energy, Office of Oil and Natural Gas Policy, Foreign Energy Ventures in the Former Sovlet Unlon and Easlem Europe (July 1996); U.S. Department of Energy, Office of Oil and Natural Gas Policy, U.S. Energy Ventures in the Former Soviet Union and Eastern Europe (July 1996); U.S. Department of Energy, Office of Oil and Natural Gas Policy, Forelgn Energy Ventures in the Baltic States and Eastem Europe (May 1996); and U.S. Department of Energy, Office of Oil and Natural Gas Pollcy, U.S. Energy Ventures in the Baltic States and Eastern Europe (May 1996). 
Table A5. Privatization-motivated Energy Investment in Asia.

\begin{tabular}{|c|c|c|c|c|c|c|c|c|c|c|}
\hline Country of Incorporation & $\begin{array}{l}\text { Sweden/ } \\
\text { Switzerland }\end{array}$ & U.S. & U.S. & U.S. & U.S. & U.S. & U.S. & U.S. & U.S. & U.S. \\
\hline Company & $\begin{array}{c}\text { ABB Energy } \\
\text { Ventures }\end{array}$ & AES Corp & $\begin{array}{c}\text { Amerada } \\
\text { Hess }\end{array}$ & $\begin{array}{c}\text { American } \\
\text { Electric Power } \\
\text { Co } \\
\end{array}$ & Amoco & Anadarko & Apache & ARCO & $\begin{array}{c}\text { Bechtel } \\
\text { Enterprises } \\
\text { Inc. }\end{array}$ & $\begin{array}{l}\text { Besicorp } \\
\text { Group inc. }\end{array}$ \\
\hline $\begin{array}{l}\text { Primary Business of } \\
\text { Company (SIC Code) }\end{array}$ & 3823 & 4911 & 2911 & 4911 & 2911 & 1311 & 1311 & 1311 & - & 3433 \\
\hline Parent/subsidiary & - &.- & $\ldots$ & - & - & $\because$ & $\ldots$ & - & - & $\ldots$ \\
\hline Year of Annual Report & $\ldots$ & 1995 & -. & 1995 & 1995 & 1995 & 1995 & 1995 & - & 1995 \\
\hline \multicolumn{11}{|l|}{ Country } \\
\hline Cambodia .......... & -- & -- & -- & -- & - & -- & A & - & -- & -- \\
\hline China ............. & $P G$ & HE,CFP/OFP & - & JV,CFP, pg,CW & $A, D, c p$ & sw & -- & $A, E, p, R, P C, c b m$ & -- & $\mathrm{pg}$ \\
\hline India $: \ldots \ldots \ldots \ldots$ & -- & CFP & - & -- & eor, s,cbm & -- & * & -- & OFP,gfe & pg \\
\hline Indonesia .......... & -. & $\mathrm{pg}$ & -- & -. & - & $\mathrm{E}$ & -- & $E$ & -- & $\mathrm{pg}$ \\
\hline 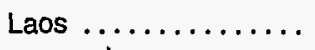 & -- & -- & -- & $\ldots$ & - & -- & -- & -- & -- & - \\
\hline Malaysia ........... & -- & - & -- & - & - & -. & -. & -- & -- & -- \\
\hline Myanmar $\ldots \ldots \ldots$. & -. &.- & -- & 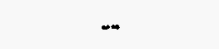 & $-A$ & -- & -- & -- & -- & - \\
\hline Pakistan ........... & ge & OFP,IPP,NS & -- & $\mathrm{CW}$ & s & -- & -- & -- & jV-OFP & $\mathrm{pg}$ \\
\hline Phillpines ......... & GFE & - & - & -- & - & - & -- & -- & -- & - \\
\hline Thailand ........... & - & -- & - & -- & -- & - & -- & -- & -. & -- \\
\hline Viétnam $\ldots \ldots \ldots \ldots$ & - & $\mathrm{pg}$ & $\mathrm{A}$ & --- & -- & - & - & A & .. & .- \\
\hline
\end{tabular}


Table A5. Privatization-motivated Energy Investment in Asia (Continued).

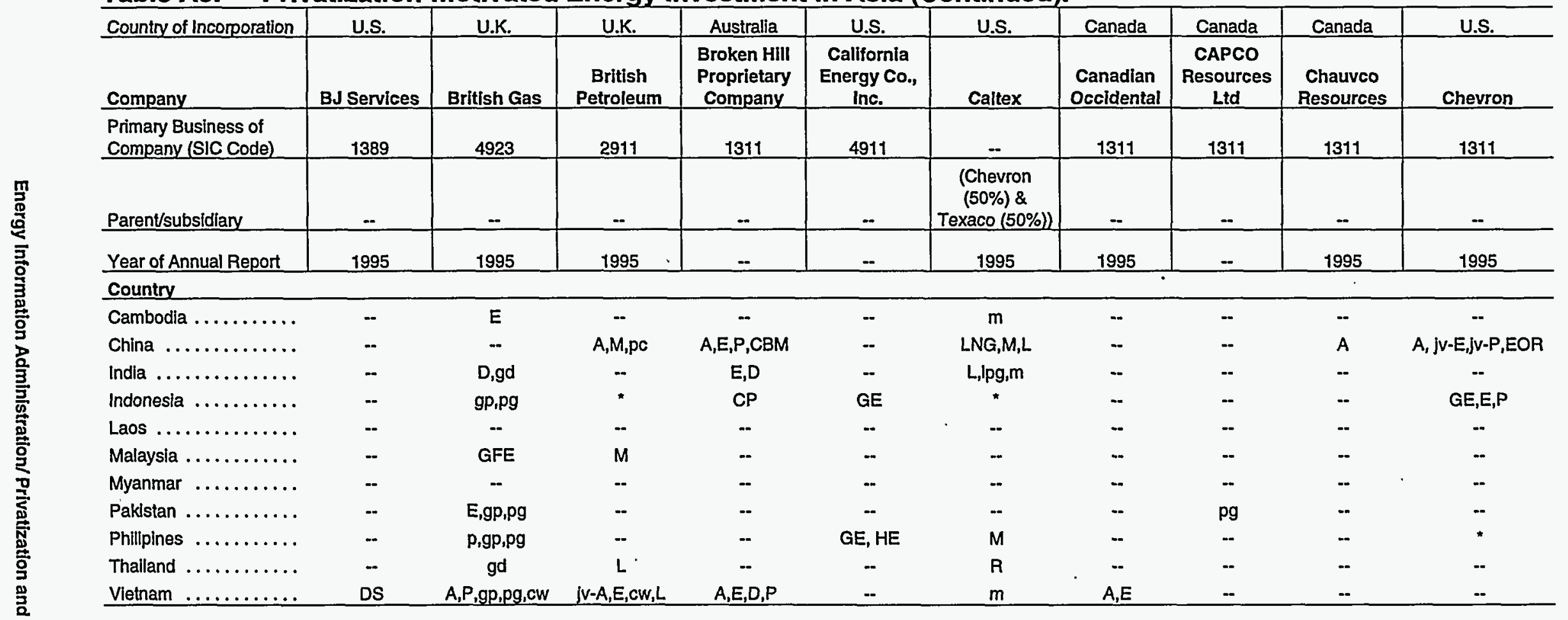


Table A5. Privatization-motivated Energy Investment in Asia (Continued).

\begin{tabular}{|c|c|c|c|c|c|c|c|c|c|c|}
\hline Country of Incorporation & U.K. & U.S. & U.S. & U.S. & U.K. & U.S. & U.S. & Hong Kong & U.S. & U.S. \\
\hline Company & $\begin{array}{c}\text { Clyde } \\
\text { Petroleum }\end{array}$ & CMS Energy & $\begin{array}{c}\text { Coastal } \\
\text { Corporation }\end{array}$ & $\begin{array}{l}\text { Cogentrix } \\
\text { Energy Inc. }\end{array}$ & \begin{tabular}{|c}
$\begin{array}{c}\text { Commonwealth } \\
\text { Development } \\
\text { Corp. }\end{array}$ \\
\end{tabular} & $\begin{array}{c}\text { Community } \\
\text { Energy } \\
\text { Alternatives } \\
\end{array}$ & Conoco & $\begin{array}{l}\text { Consolldated } \\
\text { Electric } \\
\text { Power Asia } \\
\text { (CEPA) } \\
\end{array}$ & CPC & $\begin{array}{c}\text { Crestone } \\
\text { Energy }\end{array}$ \\
\hline $\begin{array}{l}\text { Primary Business of } \\
\text { Company (SIC Code) }\end{array}$ & 1311 & 4911 & 2911 & - & - & - & 2911 & 1629 & - & $=$ \\
\hline Parent/subsidiary & - & - & - & - & - & \begin{tabular}{|c|} 
(subsidiary of \\
Public Service \\
Enterprise \\
Group)
\end{tabular} & $\begin{array}{c}\text { (subsidlary of } \\
\text { du Pont) }\end{array}$ & $\begin{array}{c}\text { (subsidiary of } \\
\text { Hopewell) }\end{array}$ & -- & - \\
\hline Year of Annual Report & .. & 1995 & 1995 & - & - & -- & -. & $\ldots$ & - & - \\
\hline \multicolumn{11}{|l|}{ Country } \\
\hline Cambodia & -- & - & -. & - & -- & -- & -. & - & -- & .. \\
\hline China........... & -- & $e, p$ & A,OFP,pg & -- & -- & CFP,cfp & $\theta, d, j v-R$ & -. & -. & A \\
\hline india $\ldots \ldots \ldots \ldots \ldots$ & -- & GFE & -- & $\mathrm{pg}$ & -- & ge & -- & -- & - & -. \\
\hline Indonesia.......... & $\mathbf{P}$ & -- & e & -- & -- & -- & -. & -- & -- & -. \\
\hline Laos ............... & -- & -- & -. & -- & -- & -- & $\therefore$ & - & -- & -- \\
\hline Malaysia ............ & -- & -- & -. & - & -- & -- & - & - & -- & -. \\
\hline Myanmar $\ldots \ldots \ldots \ldots$ & -- & -- & -. & - & -- & -- & -- & -- & -. & -. \\
\hline Pakistan ............ & .. & -.' & cfp,gfe & - & - & -- & -- & $-\cdot$ & $-\cdot$ & -- \\
\hline Philipines ........... & -- & C/OFP & -- & -- & CFP & -- & $\therefore$ & CFP & -- & -- \\
\hline Thailand ............ & -- & - & -- & - & -- & - & - & -- & -- & -. \\
\hline Vietnam & A & -. & .. & -- & -- & -. & $j-e, r$ & - & A & - \\
\hline
\end{tabular}


Table A5. Privatization-motivated Energy Investment in Asia (Continued).

\begin{tabular}{|c|c|c|c|c|c|c|c|c|c|}
\hline Country of Incorporation & German & U.S. & U.S. & U.S. & U.S. & U.S. & France & U.S. & U.S. \\
\hline Company & Deminex & $\begin{array}{l}\text { Destec } \\
\text { Energy }\end{array}$ & Duke Power & $\begin{array}{c}\text { E.l. du Pont de } \\
\text { Nemours }\end{array}$ & $\begin{array}{c}\begin{array}{c}\text { Edison } \\
\text { International }\end{array} \\
\end{array}$ & \begin{tabular}{|c|}
$\begin{array}{c}\text { Edison Mission } \\
\text { Energy Co. }\end{array}$ \\
\end{tabular} & Elf Aquitaine & Enron & Enserch Corp. \\
\hline $\begin{array}{l}\text { Primary Business of } \\
\text { Company (SIC Code) }\end{array}$ & - & 8711 & 4911 & 2911 & 4911 & 4911 & 2911 & 1321 & 4923 \\
\hline Parent/subsidiary & $\begin{array}{r}\text { (affiliate of } \\
\text { Wintershall) }\end{array}$ & - & - & $\begin{array}{l}\text { (parent of } \\
\text { Conoco) }\end{array}$ & $\begin{array}{c}\text { (parent of } \\
\text { Edison Mission } \\
\text { Energy) }\end{array}$ & $\begin{array}{l}\text { (subsidiary of } \\
\text { Edison } \\
\text { International) }\end{array}$ & -- & - & - \\
\hline Year of Annual Report & 1994 & -. & - & - & 1995 & 1995 & 1995 & 1995 & 1995 \\
\hline \multicolumn{10}{|l|}{ Country } \\
\hline Cambodia ........... & -- & -- & - & - & -- & -- & -- & -- & -- \\
\hline China...$\ldots \ldots \ldots$. & - & - & $P G$ & * & * & * & $A, E, M, p c$ & GFE,CBM & jv-cfp \\
\hline India $\ldots \ldots \ldots \ldots \ldots$ & -- & - & .. & * & pg & $\mathrm{pg}$ & $M$ & $A, E, D, G F E, O F P, s$ & jv-p,jv-PG \\
\hline Indonesia .......... & $E, P$ & -- & jV-CFP,EPD & * & jV-CFP & JV-CFP & -- & $P G$ & -- \\
\hline Laos .............. & -- & -- & -- & -- & -- & -- & -- & -- & -- \\
\hline Malaysia ........... & -- & - & - & $\cdots$ & - & -- & -- & -- & -- \\
\hline Myanmar........ & -- & - & - & -- & -- & -- & - & -- & - \\
\hline Pakistan ............ & -- & $\mathrm{pg}$ & $\cdots$ & * & * & * & - & jv-OFP,IPP,s & - \\
\hline Philipines ........... & - & -- & $\cdots$ & * & * & * & - & gfe & -- \\
\hline Thailand ............ & - & -- & - & -- & * & * & -- & & - \\
\hline Vietnam $\ldots \ldots \ldots \ldots$ & - & -- & $\therefore$ & -- & * & * & $A, M$ & LPG plant & - \\
\hline
\end{tabular}


Table A5. Privatization-motivated Energy Investment in Asia (Continued).

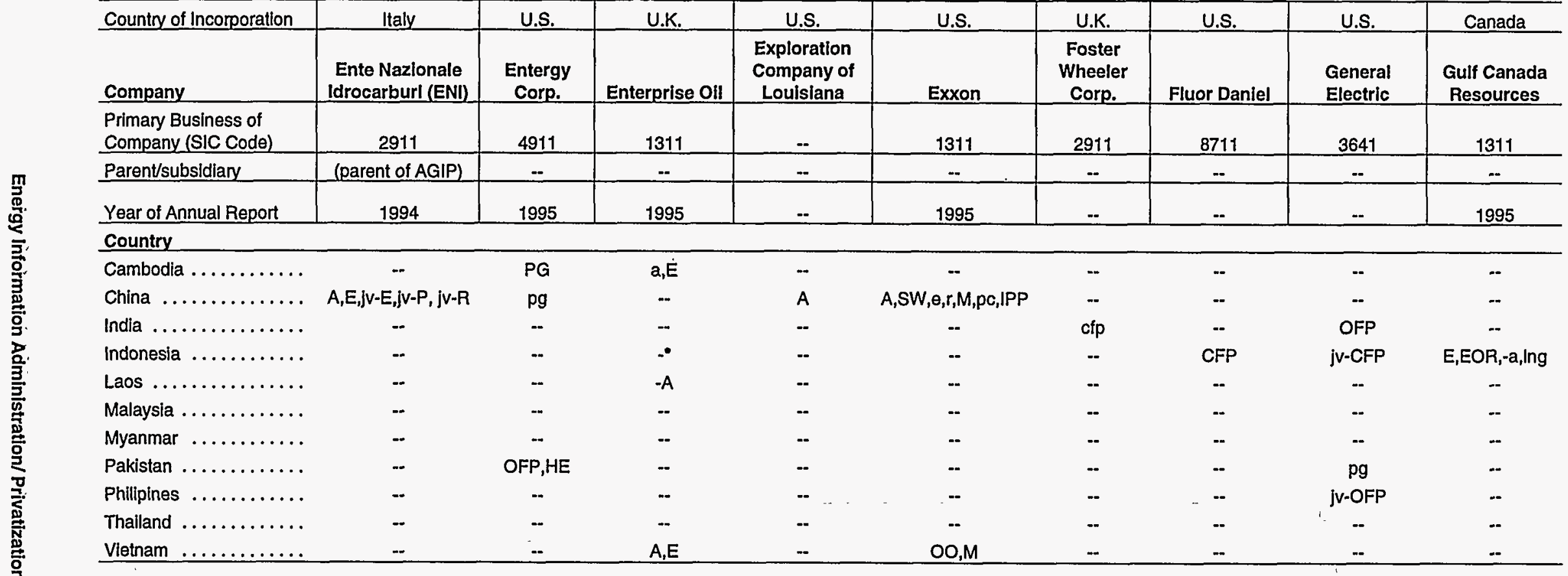


Table A5. Privatization-motivated Energy Investment in Asia (Continued).

\begin{tabular}{|c|c|c|c|c|c|c|c|c|c|}
\hline Country of Incompration & Hong Kong & U.S. & Canada & Japan & Japan & Japan & Japan & U.K. & U.S. \\
\hline Company & $\begin{array}{c}\text { Hopewell } \\
\text { Energy }\end{array}$ & $\begin{array}{c}\text { Houston } \\
\text { Industries Inc. }\end{array}$ & $\begin{array}{l}\text { Hydro Energy } \\
\text { Develop Corp. }\end{array}$ & $\begin{array}{c}\text { Ishikawajlma- } \\
\text { Harima }\end{array}$ & Itochu Corp. & $\begin{array}{c}\text { Japan National } \\
\text { Oil Corp. }\end{array}$ & JHN Group & $\begin{array}{c}\text { John Laing } \\
\text { PLC }\end{array}$ & $\begin{array}{c}\text { K\&M } \\
\text { Engineering \& } \\
\text { Consulting } \\
\end{array}$ \\
\hline $\begin{array}{l}\text { Primary Business of } \\
\text { Company (SIC Code) }\end{array}$ & 1622 & 4911 & -- & 3530 & 5050 & - & - & 1542 & - \\
\hline Parent/subsidiary & $\begin{array}{l}\text { (parent of } \\
\text { CEPA) }\end{array}$ & - & - & -- & - & - & - & -- & $=$ \\
\hline Year of Annual Report & - & 1995 & - & - & -- & - & - & - & $=$ \\
\hline \multicolumn{10}{|l|}{ Country } \\
\hline Cambodia ............ & -- & - & - & - & - & -- & - & - & -- \\
\hline China...$\ldots \ldots \ldots$ & CFE & - & - & - & jv-A & A & $j v-A, P$ & -- & - \\
\hline India $\ldots . . . \ldots \ldots \ldots$ & pg & CFP,JV-OFP & - & - & - & -- & -- & - & $\mathrm{pg}$ \\
\hline Indonesia ............ & $\mathrm{pg}$ & -- & - & - & - & -- & -- & -- & -- \\
\hline Laos ............... & - & -- & -- & $\cdots$ & -- & -- & -- & - & -- \\
\hline Malaysia ............ & - & -- & -- & - & -- & -- & -- & GFE & -- \\
\hline Myanmar......... & -- & $\cdots$ & -- & - & - & -- & $\cdots$ & -- & 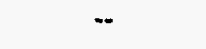 \\
\hline Pakistan ........... & -- & $P G$ & - & OFP & - & -- & -- & -- & OFP \\
\hline Phillpines ........... & OFP,CFP & - & he,pg & - & -- & -- & - & -- & - \\
\hline Thailand $\ldots \ldots \ldots \ldots$ & -- & .. & -- & -- & -- & -- & - & -- & - \\
\hline Vietnam $\ldots \ldots \ldots \ldots$ & - & - & - & - & A & $A, E, D$ & - & -- & - \\
\hline
\end{tabular}


Table A5. Privatization-motivated Energy Investment in Asia (Continued).

\begin{tabular}{|c|c|c|c|c|c|c|c|c|c|c|}
\hline & & & & & & & & & & \\
\hline Country of Incorporation & U.S. & U.S. & U.S. & S. Korea & Kuwait & U.K. & S.Korea & U.S. & U.S. & Japan \\
\hline Company & $\begin{array}{c}\text { Kansas City } \\
\text { Power \& } \\
\text { Light }\end{array}$ & Kerr-Mcgee & Klewit Energy & $\begin{array}{c}\text { Korea } \\
\text { Electric } \\
\text { Power Corp. }\end{array}$ & $\begin{array}{c}\text { Kuwalt } \\
\text { Petroleum } \\
\text { Corp. }\end{array}$ & Lasmo & LG Group & $\begin{array}{c}\text { Loulsiana } \\
\text { Land \& } \\
\text { Exploration }\end{array}$ & $\begin{array}{l}\text { Magma } \\
\text { Power }\end{array}$ & $\begin{array}{c}\text { Marubeni } \\
\text { Corp. }\end{array}$ \\
\hline $\begin{array}{l}\text { Primary Business of } \\
\text { Company (SIC Code) }\end{array}$ & 4911 & 1311 & $=$ & 4911 & - & 1311 & - & 1311 & 4911 & 5080 \\
\hline Parentsubsidiary & - & - & - & -. & - & - & -- & - & $\begin{array}{l}\text { (subsidiany of } \\
\text { Callif. Energy) } \\
\end{array}$ & $\begin{array}{c}\text { (parent of } \\
\text { Sithe) }\end{array}$ \\
\hline Year of Annual Report & - & 1995 & - & .. & .. & .. & - & 1995 & -- & .. \\
\hline \multicolumn{11}{|l|}{ Country } \\
\hline Cambodia ...... & - & - & -- & -- & -- & -- & -- & -- & -- & -- \\
\hline China $\ldots \ldots \ldots \ldots \ldots$ & $P G$ & $A, D$ & - & -- & A & -- & - & -. & -- & OFP \\
\hline Indla ..... & -- & -- & - & -- & -- & -- & -- & - & -- & gfe \\
\hline Indonesia $\ldots \ldots \ldots \ldots$ & -- & D & GE & -- & - & -- & -- & $D, P$ & -- & -- \\
\hline Laos ......... & -- & - & -- & -- & - & -- & -- & -- & - & -- \\
\hline Malaysia $\ldots \ldots \ldots \ldots$ & -- & - & -- & -- & - & -. & -- & -- & -- & -- \\
\hline Myanmar ............ & - & - & -- & -- & - & -- & -- & -- & - & - \\
\hline Pakistan & & -- & -- & -- & -- & -- & -- & -- & -- & -- \\
\hline Phillipines $\ldots \ldots \ldots \ldots$ & -. & -- & GE & OFP & -- & -- & -- & -- & GE & -- \\
\hline Thailand $\ldots \ldots \ldots \ldots$ & -- & - & -- & -- & -- & -- & -- & -- & -- & - \\
\hline Vietnam $\ldots \ldots \ldots \ldots$ & - & A & - & - & -- & $A, D$ & $j v-r$ & -- & -- & - \\
\hline
\end{tabular}


Table A5. Privatization-motivated Energy Investment in Asia (Continued).

\begin{tabular}{|c|c|c|c|c|c|c|c|c|c|c|}
\hline Country of Incorporation & U.S. & U.S. & Japan & Japan & U.S. & U.K. & U.S. & U.S. & U.K. & U.S. \\
\hline Company & $\begin{array}{c}\text { Maxus } \\
\text { Energy Corp. }\end{array}$ & $\begin{array}{c}\text { Mission } \\
\text { Energy } \\
\text { Company } \\
\end{array}$ & Mitsubishi & Mitsui \& Co. & Mobil & Monument Oil & $\begin{array}{c}\text { Montana } \\
\text { Power Co. }\end{array}$ & $\begin{array}{l}\text { Murphy Oil } \\
\text { Co. }\end{array}$ & $\begin{array}{c}\text { National } \\
\text { Power PLC }\end{array}$ & $\begin{array}{c}\text { Nevada } \\
\text { Power }\end{array}$ \\
\hline $\begin{array}{l}\text { Primary Business of } \\
\text { Company (SIC Code) }\end{array}$ & 1311 & 4911 & 5050 & 6221 & 1311 & 1311 & 4931 & 2911 & 4911 & 4911 \\
\hline Parent/subsidiary & $\begin{array}{c}\text { (subsidiary of } \\
\text { YPF) }\end{array}$ & $\begin{array}{l}\text { (subsidiany of } \\
\text { Edison } \\
\text { International) }\end{array}$ & - & - & - & - & 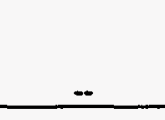 & - & - & -- \\
\hline Year of Annual Report & - & $=$ & $\ddot{-}$ & $=$ & 1995 & $=$ & 1995 & - & 1995 & - \\
\hline \multicolumn{11}{|l|}{ Country } \\
\hline Cambodia ............. & - & -- & - & -- & - & - & - & - & - & - \\
\hline China $\ldots \ldots \ldots \ldots \ldots$ & A & PG & A & A & $O O, P, M, L$ & -- & -- & A & jv-cfp & -- \\
\hline India $\ldots \ldots \ldots \ldots \ldots$ & -- & $\mathrm{pg}, \mathrm{PG}$ & - & -- & - & -- & cfp & -- & jv-cfp & -- \\
\hline Indonesia ............ & -- & jv-CFP & - & Jv-CFP & D,gfe & -- & -- & -- & - & -- \\
\hline Laos .............. & -- & -- & -- & -- & - & -- & -- & -- & - & - \\
\hline Malaysia ............ & - & -- & - & -- & M & - & -- & -- & -- & - \\
\hline Myanmar.......... & -- & -- & - & -- & - & -- & -- & -- & -- & -- \\
\hline Pakistan ............. & -- & $P G$ & -. & OFP & -- & -- & -- & -- & OFP & -- \\
\hline Philipines $\ldots \ldots \ldots \ldots$ & -- & PG & -- & -- & -- & -- & -- & -- & -- & PG \\
\hline Thailand $\ldots \ldots \ldots \ldots$ & - & PG & -- & -- & M & -- & -- & -- & -- & -- \\
\hline Vietnam & $\approx$ & -- & $A, E, D$ & A & $A, E, C W$ & A & - & - & - & - \\
\hline
\end{tabular}


Table A5. Privatization-motivated Energy Investment in Asia (Continued).

\begin{tabular}{|c|c|c|c|c|c|c|c|c|}
\hline Country of Incorporation & Japan & Norway & U.S. & U.S. & U.S. & U.S. & Austria & India \\
\hline Company & Nippon Oll & Norsk Hydro & $\begin{array}{c}\text { Northern States } \\
\text { Power } \\
\end{array}$ & NRG Energy & Occidental & Ogden Products & OMV & ONGC \\
\hline $\begin{array}{l}\text { Primary Business of } \\
\text { Company (SIC Code) }\end{array}$ & 2911 & 2873 & 4931 & 4931 & 2812 & 4953 & 2911 & - \\
\hline Parent/subsidiary & - & 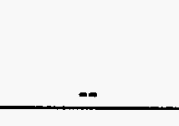 & $\begin{array}{c}\text { (parent of NRG } \\
\text { Energy) }\end{array}$ & $\begin{array}{c}\text { (subsidlary of } \\
\text { Northem States } \\
\text { Power) }\end{array}$ & - & $=$ & - & - \\
\hline Year of Annual Report & -. & 1994 & 1995 & .- & 1995 & .. & .. & . \\
\hline
\end{tabular}

Country

Cambodia

$\ldots \ldots \ldots \ldots$

India

Indonesia

Laos...

Malaysia

Myanmar

Pakistan

Phillipines

Thailand

Vietnam

$\begin{array}{cc}-- & -- \\ A, E & -- \\ -- & -- \\ -- & -- \\ -- & -- \\ -- & -- \\ E & -- \\ -- & -- \\ -- & -- \\ -- & -- \\ -- & \text { A,E }\end{array}$

$\begin{array}{ll}-- \\ -- \\ -- \\ -- \\ -- \\ -- \\ -- \\ \text { he } \\ -- & \\ -- & \\ -- & \end{array}$

\begin{tabular}{ccc}
-- & - & - \\
-- & $A, D R$ & - \\
-- & -- & - \\
-- & -- & - \\
-- & Ing & - \\
-- & -- & - \\
-- & -- & - \\
he & A,e,SW,jv-P,-P & pg \\
-- & -- & - \\
-- & PC & - \\
-- & A,E & - \\
\hline
\end{tabular}

\begin{tabular}{ll}
-- & -- \\
-- & - \\
-- & - \\
-- & - \\
-- & -- \\
- & -- \\
-- & -- \\
- & -- \\
- & -- \\
-- &.- \\
A,E & A,E \\
\hline
\end{tabular}


Table A5. Privatization-motivated Energy Investment in Asia (Continued).

\begin{tabular}{|c|c|c|c|c|c|c|c|c|c|}
\hline Country of Incorporation & U.S. & U.S. & Belgium & Malaysia & U.S. & U.K. & U.K. & U.S. & Spain \\
\hline Company & Pacific G\&E & Pennzoil & Petrofina S.A. & Petronas & $\begin{array}{l}\text { Phillips } \\
\text { Petroleum }\end{array}$ & PowerGen & Premier Oil ple & $\begin{array}{c}\text { Public Service } \\
\text { Enterprise } \\
\text { Group }\end{array}$ & Repsol \\
\hline $\begin{array}{l}\text { Primary Business of } \\
\text { Company (SIC Code) }\end{array}$ & 4931 & 2911 & 1311 & - & 2911 & 4911 & 1311 & 4931 & 2911 \\
\hline Parent/subsidiany & - & - & -- & - & - & -- & - & - & - \\
\hline Year of Annual Report & - & -- & - & - &.- & 1995 & 1995 & - & - \\
\hline Cambodia .............. & - & - & $\therefore$ & - & .. & $\ldots$ & $E$ & -- & -. \\
\hline China............ & $\mathrm{pg}$ & - & -- & A & $j v-A, P$ & $\mathrm{pg}$ & $A, E$ & CFP,cfp & -- \\
\hline India $\ldots \ldots \ldots \ldots \ldots$ & OFP,gfo & m & -- & -- & - & GFE & -- & - & Gas Operation \\
\hline Indonesia ............ & -- & - & -- & -. & -- & jV-CFP & $A, \Theta$ & -- & -- \\
\hline Laos ................. & -- & - & -- & - & -- & -- & -- & -- & -- \\
\hline Malaysia ............. & -- & - & -- & -- & $-:$ & -- & -- & -- & -- \\
\hline Myanmar....$\ldots \ldots \ldots$ & -- & - & -- & -- & -- & -. & $A, E$ & -- & -. \\
\hline Pakistan ............. & -- & - & -- & -- & -. & -. & E,P,Ipp & -- & -- \\
\hline Philipines...$\ldots \ldots \ldots$ & -- & -- & -- & -- & -. & $\cdots$ & -- & -- & -. \\
\hline Thalland...$\ldots \ldots \ldots$ & -- & - & -- & -- & - & -. & -- & -- & -- \\
\hline Vietnam $\ldots \ldots \ldots \ldots \ldots$ & - & - & $A, E$ & $A, E, D, P, j v-r$ & -- & - & -- & - & -. \\
\hline
\end{tabular}


Table A5. Privatization-motivated Energy Investment in Asia (Continued).

\begin{tabular}{|c|c|c|c|c|c|c|c|c|c|c|}
\hline Country of Incorporation & $\begin{array}{c}\text { The Netherlands } \\
\text { NU.K. }\end{array}$ & U.S. & Australla & U.S. & Germany & U.S. & U.S. & U.S. & U.S. & U.S. \\
\hline Company & $\begin{array}{c}\text { Royal } \\
\text { Dutch/Shell }\end{array}$ & $\begin{array}{c}\text { Sante Fe } \\
\text { Resources }\end{array}$ & Santos Ltd & SCECorp & Siemens & $\begin{array}{l}\text { Sithe } \\
\text { Energles }\end{array}$ & $\begin{array}{c}\text { Smith } \\
\text { Cogeneration } \\
\end{array}$ & $\begin{array}{c}\text { Snyder oil } \\
\text { Corp }\end{array}$ & $\begin{array}{l}\text { Southern } \\
\text { Company }\end{array}$ & $\begin{array}{c}\text { Southern } \\
\text { Electric } \\
\text { International }\end{array}$ \\
\hline $\begin{array}{l}\text { Primary Business of } \\
\text { Company (SIC Code) }\end{array}$ & 1311 & 1311 & 1311 & 4911 & 3661 & 4911 & - & 1311 & 4911 & 4911 \\
\hline Parent/subsidiary & - & - & - & $\begin{array}{c}\text { (parent of } \\
\text { Edison } \\
\text { Misslon } \\
\text { Energy) } \\
\end{array}$ & .- & $\begin{array}{l}\text { (subsidiary of } \\
\text { Marubeni) }\end{array}$ & - & - & $\begin{array}{c}\text { (parent of } \\
\text { Southern } \\
\text { Electric } \\
\text { International) }\end{array}$ & $\begin{array}{l}\text { (subsidiary of } \\
\text { Southern co.) } \\
\end{array}$ \\
\hline Year of Annual Report & 1995 & .- & 1995 & - & -. & - & - & 1995 & 1995 & .. \\
\hline
\end{tabular}

Country

Cambodia ..............

China

$M$

India

Indonesia

$A, r, P, j v-R, M$

$-$

$-$

Laos .................

Malaysia . .

$E, M$

Myanmar

E,P,R,M,PG,LNG

Pakistan

E

Philipines

$E, R, M$

Thalland

$E, P, R, M, P C$

Vietnam

$A, E, D, M$

$\begin{array}{ll}-- & - \\ -- & O \\ -- & - \\ -- & E_{1} \\ -- & - \\ -- & - \\ \text { A } & - \\ -- & - \\ -- & - \\ -- & - \\ -- & -\end{array}$

$\begin{array}{cc}-. & -- \\ O O & P G \\ -- & P g, P G \\ E, P & \text { CFP } \\ -- & -- \\ -- & -- \\ -. & -- \\ -- & P G \\ -- & P G \\ -- & P G \\ -- & --\end{array}$

\begin{tabular}{cc}
-- & - \\
-- & OFP \\
-- & gfe \\
JV-CFP & -- \\
-- & -- \\
-- & -- \\
-- & -- \\
-- & -- \\
-- & - \\
-- & - \\
-- & - \\
\hline
\end{tabular}

--
pg
--
--
--
--
cfp
--
--
--

--
--
d,P
--
--
--
--
--
--
--
a,e,d


Table A5. Privatization-motivated Energy Investment in Asia (Continued).

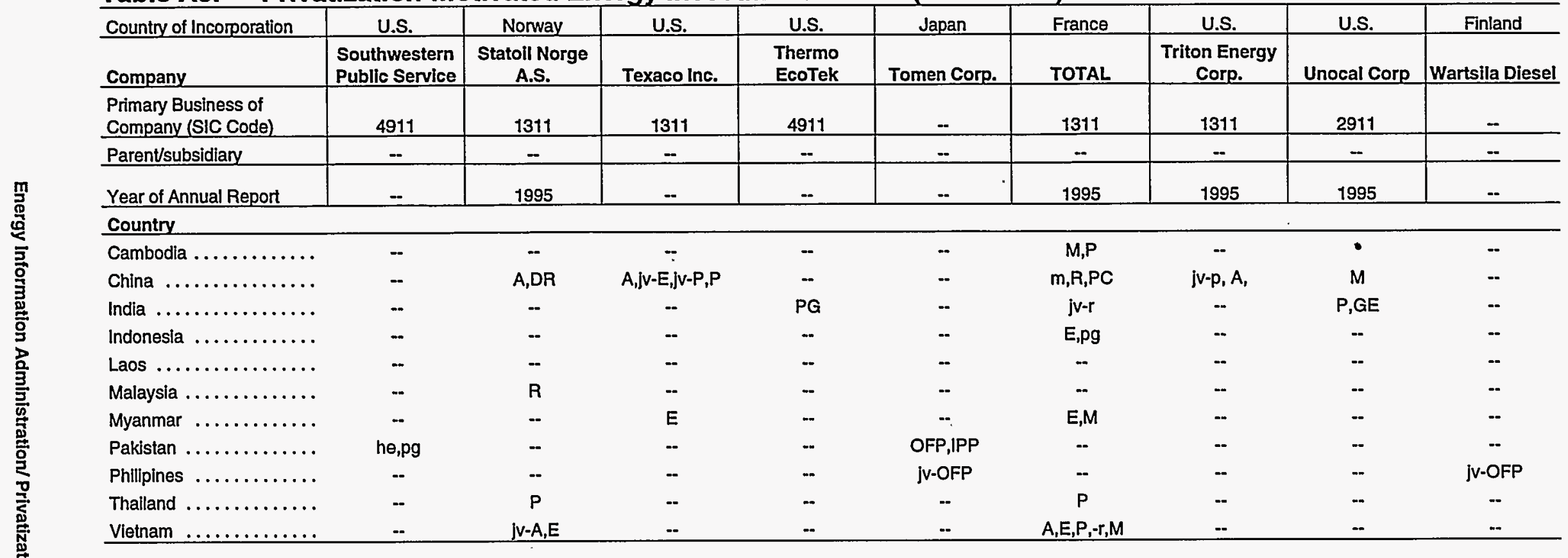


Table A5. Privatization-motivated Energy Investment in Asia (Continued).

\begin{tabular}{l|c|c|c|c|c}
\hline Country of Incorporation & U.S. & U.S. & U.S. & Saudi Arabia & S.Korea \\
\hline Company & $\begin{array}{c}\text { West Coast } \\
\text { Energy }\end{array}$ & $\begin{array}{c}\text { Western } \\
\text { Resources }\end{array}$ & WPL Holdings & Xenel Group & $\begin{array}{c}\text { Yukong } \\
\text { Limited }\end{array}$ \\
\hline Primary Business of Company (SIC Code) & -- & 4911 & 4931 & - & 2911 \\
\hline Parentsubsidiary &.- &.- & - & - & - \\
\hline Year of Annual Report &.- & - & - & - & 1995 \\
\hline
\end{tabular}

\section{Country}

Cambodia

1995

China .

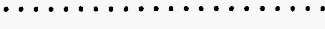

$\cdot-$

....................

$-$

Indonesia

Malaysia

Myanmar

$\cdot-$

-.

Philipines

Thailand

Vietnam

--

$-$

-

Sources: Various company annual reports; The Mead Corporation, Lexis-Nexis; Disclosure Incorporated, Compact Disclosure and Worldscope Disclosure; U.S. Department of Energy, Office of Oil and Natural Gas Policy, U.S. Energy Ventures in China (May 1996); U.S. Department of Energy, Office of Oil and Natural Gas Policy, U.S. Energy Ventures in India (June 1995); U.S. Department of Energy, Office of Oil and Natural Gas Policy, U.S. Energy Ventures in Pakistan (May 1995); and U.S. Department of Energy, Office of Oil and Natural Gas Policy, U.S. Energy Ventures in South Asia (June 1996) 
Table A6. Privatization-motivated Energy Investment in Africa.

\begin{tabular}{|c|c|c|c|c|c|c|c|c|c|c|}
\hline Country of Incorporation & $\begin{array}{c}\text { Sweden/ } \\
\text { Switzerland }\end{array}$ & U.S. & U.S. & U.S. & U.S. & U.K. & U.K. & Australia & U.S. & U.K. \\
\hline Company & $\begin{array}{c}\text { ABB Energy } \\
\text { Ventures }\end{array}$ & Amoco & Anadarko & ARCO & Ashland & British Gas & $\begin{array}{c}\text { British } \\
\text { Petroleum }\end{array}$ & $\begin{array}{c}\text { Broken Hill } \\
\text { Proprietary } \\
\text { Company }\end{array}$ & Chevron & $\begin{array}{c}\text { Clyde } \\
\text { Petroleum }\end{array}$ \\
\hline $\begin{array}{l}\text { Primary Business of } \\
\text { Company (SIC Code) }\end{array}$ & 3823 & 2911 & 1311 & 1311 & 2911 & 4923 & 2911 & 1311 & 1311 & 1311 \\
\hline Parent/subsidiary & - & - & - & $\ldots$ & -- & - & - & - & -- & - \\
\hline Year of Annual Report & - & 1995 & 1995 & 1995 & - & 1995 & 1995 & $\ldots$ & 1995 & - \\
\hline \multicolumn{11}{|l|}{ Country } \\
\hline Algeria....$\ldots \ldots \ldots$ & -- & - & $E, P$ & E,EOR & -- & - & $e, p$ & $E, D$ & -- & -- \\
\hline Ivory Coast $\ldots \ldots \ldots \ldots$ & -- & -- & - & -- & -. & - & -- & -- & -- & -- \\
\hline Morocco...$\ldots \ldots \ldots$ & JV-Ipp & -- & - & - & - & - & -- & - & -- & -- \\
\hline Mozambique ......... & -- & -- & -- & -- & - & - & -- & $\cdots$ & -- & -- \\
\hline Nigeria $\ldots \ldots \ldots \ldots$. & -- & -- & -- & -- & $\mathbf{P}$ & A & $E$ & $\cdots$ & $\mathbf{P}$ & -- \\
\hline Yemen.......... & - & $A, E$ & -- & A &.- & $E$ & - & $E, D$ & A & A \\
\hline
\end{tabular}

Table A6. Privatization-motivated Energy Investment in Africa (Continued).

\begin{tabular}{|c|c|c|c|c|c|c|c|c|c|c|}
\hline Country of Incorporation & U.S. & U.S. & U.S. & France & France & U.S. & Italy & U.S. & Canada & Kuwait \\
\hline Company & CMS Energy & Conoco & $\begin{array}{l}\text { E.l. du Pont } \\
\text { de Nemours }\end{array}$ & Elf Aquitaine & $\begin{array}{c}\begin{array}{c}\text { Electricite de } \\
\text { France }\end{array} \\
\end{array}$ & Enron & $\begin{array}{c}\text { Ente } \\
\text { Nazionale } \\
\text { Idrocarburl } \\
\text { (ENI) }\end{array}$ & Exxon & $\begin{array}{c}\text { Gulf Canada } \\
\text { Resources }\end{array}$ & $\begin{array}{c}\text { Kuwait } \\
\text { Petroleum } \\
\text { Corp. }\end{array}$ \\
\hline $\begin{array}{l}\text { Primary Business of } \\
\text { Company (SIC Code) }\end{array}$ & 4911 & 2911 & 2911 & 2911 & 4911 & 1321 & 2911 & 1311 & 1311 & -- \\
\hline Parent/subsidiary & $\begin{array}{l}\text { (parent of } \\
\text { Nomeco Oil } \\
\text { and Gas) }\end{array}$ & $\begin{array}{c}\text { (subsidiary of } \\
\text { du Pont) }\end{array}$ & $\begin{array}{l}\text { (parent of } \\
\text { Conoco) }\end{array}$ & 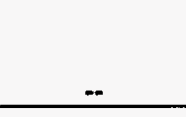 & - & -- & - & $\cdots$ & -- & - \\
\hline Year of Annual Report & 1995 & _- & -. & 1995 & - & 1995 & 1994 & 1995 & 1995 & -- \\
\hline \multicolumn{11}{|l|}{ Country } \\
\hline Algeria $\ldots \ldots \ldots \ldots$. & -- & -- & -- & -- & - & -- & A & DR & $j V-E$ & -- \\
\hline Ivory Coast .......... & $-\cdot$ & -- & -- & -- & $P G$ & - & -- & - & -- & - \\
\hline Morocco...$\ldots \ldots$ & $c f \theta, p g, j v-i p p$ & -- & - & -- & - & -- & -- & - & -- & $-\cdot$ \\
\hline Mozambique........ & -- & $-\cdot$ & -- & -- & - & $\mathrm{pg} / \mathrm{gp}$ & -- & -- & - & -- \\
\hline Nigeria...$\ldots \ldots \ldots$ & -- & A & $\star$ & $P$ & - & $e, d, g p$ & $E, D$ & D & -- & -- \\
\hline Yemen.......... & A & -- & -- & $E$ & - & Ing & A & $P$ & -- & $\mathbf{P}$ \\
\hline
\end{tabular}


Table A6. Privatization-motivated Energy Investment in Africa (Continued).

\begin{tabular}{|c|c|c|c|c|c|c|c|c|c|c|}
\hline Counity of Incorporation & U.K. & U.S. & U.S. & Finland & Norway & U.S. & Austria & U.S. & Canada & Malaysia \\
\hline Company & Lasmo & $\begin{array}{l}\text { Louislana } \\
\text { Land \& } \\
\text { Exploration }\end{array}$ & Mobil & Neste Oy & Norsk Hydro & Occidental & OMV & $\begin{array}{c}\text { Oryx Energy } \\
\text { Co. }\end{array}$ & Petro Canada & Petronas \\
\hline $\begin{array}{l}\text { Primary Business of } \\
\text { Company (SIC Code) }\end{array}$ & 1311 & 1311 & 1311 & 2911 & 2873 & 2812 & 2911 & 1311 & 2911 & - \\
\hline Parent/subsidiary & $\ldots$ & -- & & - & .- & $\div$ & $\div$ & $\ldots$ & -- & - \\
\hline Year of Annual Report & -- & 1995 & 1995 & -- & 1994 & 1995 & - & 1995 & 1994 & -- \\
\hline \multicolumn{11}{|l|}{ Country } \\
\hline Algeria ........... & $\mathbf{E}$ & E,SW & A & A & -- & D & -- & $E, D$ & E,D,P & - \\
\hline Ivory Coast .......... & -- & -- & -- & -- & -- & -- & -- & -. & -- & - \\
\hline Morocco ........... & -- & $\cdots$ & -- & -- & -- & -- & -- & -- & -- & -- \\
\hline Mozambique ........ & -- & -- & -- & -- & -- & -- & -- & -- & -- & -- \\
\hline Nigeria...$\ldots \ldots \ldots$ & -- & -- & $P$ & -- & -- & A & -- & -- & -- & -- \\
\hline Yemen...$\ldots \ldots \ldots$ & A & $\mathrm{D}$ & -- & $\therefore$ & $E$ & jv-P & $E$ & $\ldots$ & -- & $E$ \\
\hline
\end{tabular}

\section{Table A6. Privatization-motivated Energy Investment in Africa (Continued).}

\begin{tabular}{|c|c|c|c|c|c|c|c|c|c|c|}
\hline Country of Incorporation & U.S. & Spain & $\begin{array}{c}\text { The } \\
\text { Netherlands/ } \\
\text { U.K. } \\
\end{array}$ & Norway & U.S. & U.S. & France & U.S. & Germany & S.Korea \\
\hline Company & $\begin{array}{l}\text { Phillips } \\
\text { Petroleum } \\
\end{array}$ & Repsol & $\begin{array}{c}\text { Royal } \\
\text { Dutch/Shell }\end{array}$ & $\begin{array}{c}\text { Statoil Norge } \\
\text { A.S. }\end{array}$ & Sun Co. Inc. & Texaco Inc. & TOTAL & Unocal Corp & Veba AG & $\begin{array}{l}\text { Yukong } \\
\text { Limited }\end{array}$ \\
\hline $\begin{array}{l}\text { Primary Business of } \\
\text { Company (SIC Code) }\end{array}$ & 2911 & 2911 & 1311 & 3111 & 2911 & 1311 & 1311 & $\begin{array}{l}=- \\
2911\end{array}$ & 5172 & 2911 \\
\hline Parent/subsidiary & -- & - &.- & -- & $\ldots$ &.- & - & - & - & -- \\
\hline Year of Annual Report & - & - & 1995 & 1995 & - & - & 1995 & 1995 & - & 1995 \\
\hline \multicolumn{11}{|l|}{ Country } \\
\hline Algeria $\ldots \ldots \ldots \ldots$ & DR & $e, d$ & -. & $\therefore$ & $A$ & A & $E, d, P$ & $\cdots$ & $A$ & -- \\
\hline Ivory Coast ......... & -- & -- & -- & -- & -- & -- & -- & $\ldots$ & -- & $\therefore$ \\
\hline Morocco ........... & - & -- & 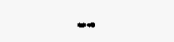 & -- & -- & -- & $\bar{M}$ & -- & - & -- \\
\hline Mozambique ......... & -- & -- & -- & -- & -- & -- & -- & -- & - & -- \\
\hline Nigeria...$\ldots \ldots \ldots$ & $P$ & -- & $E, P, M$ & $E$ & DR & $P$ & $E, M$ & -- & -- & -- \\
\hline Yemen $\ldots \ldots \ldots \ldots$ & - & - & A & - & A & - & E,LNG & $E$ & -- & $P$ \\
\hline
\end{tabular}

Sources: Various company annual reports; The Mead Corporation, Lexis-Nexis, Disclosure Incorporated, Compact Disclosure and Worldscope Disclosure; U.S. Department of Energy, Office of Oil and Natural Gas Policy, U.S. Energy Ventures in West and Southwest Africa (June 1995); and U.S. Department of Energy, Office of Oil and Natural Gas Policy, U.S. Energy Ventures in North and East Africa (November 1995). 